\title{
Michel Foucault, Social Policy and 'Limit-Experience'
}

\author{
By \\ Ian Culpitt
}

A thesis

submitted to the Victoria University of Wellington

in fulfilment of the

requirements for the degree of

Doctor of Philosophy

in Social Policy

Victoria University of Wellington

2001 
When people follow Foucault, when they're fascinated by him, it's because they're doing something with him, in their own work, in their own independent lives. It's not just a question of intellectual understanding or agreement, but of intensity, resonance, musical harmony. Good lectures, after all, are more like a concert than a sermon, like a soloist "accompanied" by everyone else. And Foucault gave wonderful lectures.

- Gilles Deleuze, Negotiations. (1995: 86)

Foucault carved numerous turns of phrase into ice-sculptures, which had, for a moment, sharp contours. Then he walked away from them insouciant, and let them melt, for he no longer needed them. His less gifted readers put the half-melted shapes in the freezer and, without thinking, reproduce these figures as if they still glistened in the midnight sun and meant something.

- Ian Hacking, Mad Travellers: Reflections on the Reality of Transient Mental Illnesses. (1998b: 85)

I can't help but dream of a kind of criticism that would try not to judge but to bring an oeuvre, a book, a sentence, an idea to life; it would light fires, watch the grass grow, listen to the wind, and catch the sea foam in the breeze and scatter it. It would multiply not judgments but signs of existence; it would summon them, drag them from their sleep ... I'd like a criticism of scintillating leaps of the imagination. It would not be sovereign or dressed in red. It would bear the lightning of possible storms.

- Michel Foucault, Ethics, Subjectivity and Truth. (1997c: 323) 


\section{Abstract}

This thesis considers whether the discipline of social policy can validly use the patterns and intentions implicit in Foucault's critique of modernity to develop a new qualitative approach to social theory. He examined the conditions under which various regimes of social and political practice came into being; how they are maintained and the particular manner of their transformation.

There are two specific emphases that establish the pattern of my overall inquiry. The first involves a reflection on the troubled and ineffectual place of normative social theory within contemporary social policy discourse. The second is a reconsideration of Foucault's oeuvre in relation to new social theory building within social policy. Both of these concerns offer an opportunity to reflect on the place of social theory within a discursive world that 'appears' cosmopolitan and diverse.

Foucault famously declared that the point of philosophical activity involved the endeavour to know how and to what extent it might be possible to think differently - to examine the functioning of our ideas as 'limit-experiences'. He coined this phrase 'limitexperience' to outline his critique of the 'forms of rationalizations' that comprise the present practice of politics within modernity. He thought the decisive question was how apparently 'universal, necessary', and obligatory discourses about political and social knowledge shapes that which ought more properly to be regarded as 'singular, contingent, and the product of arbitrary constraints'.

The former injunctive and 'magisterial' arguments that supported initial patterns of welfare state rhetoric are no longer persuasive. There has been a 'sea-change' in contemporary social ideas - from a welfare state to a welfare society - one that is breath-taking in its hegemonic compass. That world is increasingly depicted as a postmodern social world where there is little apparent respect for, let alone reliance on, the grand metaphors and social themes of classic social policy.

This reconsideration of Foucault's ideas from a social policy perspective will not necessarily yield a new compelling normative rhetoric but it will provide an opportunity to think differently about the taken-for-granted nature of so much social policy theorizing. 
His portrayal of how we might 'think differently' about the multitude of practices involved in the rationalizations and subjectifications of 'limit-experiences' provides an opportunity to reflect on the patterning and practices that construct the current discourses of welfare and social policy. We do need to think differently or at least to see if it is possible to do so. Imagining difference, strategizing for it, and welcoming it, mark us out as constantly restless - a personal style that Foucault embraced with some gusto! 


\section{Acknowledgements}

The writing of any doctoral thesis is a solitary exercise that requires a certain 'withdrawal' and absorption that directly affects those closest to you. I want to thank my wife Ginny for all the loving support of me throughout this project. It is customary to acknowledge our families in this way, but she is my friend and will always be my intellectual companion. Without her loving respect I would never have had the freedom or patience to set out on such a journey.

I have also been very lucky to have, in Associate Professor John Pratt, an academic supervisor whose own sense of intellectual integrity and ability is woven inextricably into my work here. His efforts in reading, critiquing and re-reading the manuscript have demonstrated the kind of scholarly commitment to the passionate independence of an intellectual life that I acknowledge with respect. I have been warmly supported in undertaking this work by Mike Hill - Professor of Sociology in this Department - he was also my executive supervisor. His ready humour and gentle sardonic 'eye' is always a happy goad to much intellectual cant. He has been more than ready to assist intellectually but equally to offer support when I needed temporary relief from my present duties as Head of the Department of Sociology and Social Policy.

I would also like to thank Dr Allison Kirkman for the ongoing support that she unfailingly provides both personally to me and to the life of this Department. Her awareness and care of the vicissitudes of staff and especially students in this Department I respectfully acknowledge, for she too has assisted me with some Departmental duties so that I could focus on completing this thesis. Dr David Pearson and Stephen Uttley, two other colleagues in this Department, have given me time to discuss ideas and are models of intellectual clarity that I value. I would also like to acknowledge the support of Professor David Mackay, Dean of the Faculty of Humanities and Social Sciences at this university for all his assistance in my undertaking this research whilst Head of a Department.

There are obviously many acknowledgements of support that I cannot adequately mention but I would especially like to thank my friends Professor Brian and Pat Merrilees in Toronto whose 'home away from home' provided me the base for an extensive period 
of research at The Robarts Library at the University of Toronto. I would also like to acknowledge the interest and support of my friends Professor Paul Havemann at Waikato University, Dr Ann Robertson in Toronto, Dr Giovanna Procacci in Milan and Dr Kevin White at ANU in Canberra.

Finally to my children: Emma, Jeremy, Nicholas, Martyn and Will I thank you for your being in the world with Ginny and me. I know that what Michel Foucault strove to articulate in defining an 'aesthetics of freedom', as well as setting out the 'limitexperiences' that rationalize our politics and construe our present, you all know about: and I also realize that you will contend with these ideas in your own separate ways. 


\section{Contents}

Abstract

iii

Acknowledgements

v

Chapter One:

There is no Alternative? : Contemporary 'Limits' of Social Policy

Chapter Two:

Foucault Revisited: Foucault's Place in the Modernist/Postmodernist Debate

Chapter Three:

The Various 'Foucaults'?

Chapter Four:

Reviewing Foucault: The Critical Oscillation

80

Chapter Five:

'Il faut défendre la société': Omnes and Singulatim?

Chapter Six:

'What matter who's speaking?': Social Inquiry Following Foucault

Chapter Seven:

Welfare Governance: Practices, Paradoxes and Possibilities?

Chapter Eight:

Foucault's Coldest of All Cold Monsters

Endnotes:

Bibliography: 


\section{Chapter One}

\section{There is No Alternative? : Contemporary 'Limits' of Social Policy}

After all, what would be the value of passion for knowledge if it resulted only in a certain amount of knowledgeableness and not, in one way or another and to the extent possible in the knower's straying afield of himself? There are times in life when the question of knowing if one can think differently than one thinks, and perceive differently than one sees, is absolutely necessary if one is to go on looking and reflecting at all. (Foucault, 1985: 8, my italics) ${ }^{i}$

... only by either the circumvention or the subversion of liberal modes of debate can the rationality specific to traditions of inquiry establish itself sufficiently to challenge the cultural and political hegemony of liberalism effectively. (MacIntyre, 1988: 401)

Some six years before he died in 1984 Michel Foucault, reflecting on the fractious reception of his books in France, commented to the Italian journalist Duccio Trombadori that he was concerned that there 'is a peculiar relation between the things I've written and the effects they have produced' (1991d: 34). More specifically, he expressed 'puzzlement' that Madness and Civilization, in particular, had been considered so controversial and that it had even been interpreted by some commentators as a coded attack on the French psychiatric profession. Whether these observations did indicate genuine surprise at the 'peculiar' effect that his ideas were having is difficult to say; for by then his celebrated but somewhat contentious standing in French academic circles was well established (c.f., Deleuze, 1988, 1995; Eribon, 1991; Macey, 1993; Miller, 1993a). Indicating his personal preference for how his books might be appraised Foucault said to Trombadori they should be seen and considered as 'experiences' and not regarded as 'truths', or as 'demonstrations' of some new paradigm of knowledge.

That sets the pattern, at least as far as he was concerned, for how any subsequent investigation of his ideas might be undertaken for he stated directly that he was not interested in polemics (1997c: 111). He was 'opposed to any interpretive method. Never interpret; experience, experiment' (Deleuze, 1995: 87). How accurate that is of his true intent is difficult for us to know for he was also, as Deleuze suggested, a 'terrible joker'. It was Deleuze's belief that 'Foucault always evokes the dust or murmur of battle, and he saw thought itself as a sort of war machine' (1995: 103). If these enquiries are presented as if they were able to glean the 'truth' about Foucault or their 'observations' made definitive, then they do not reflect this aspiration that his ideas should be 
considered an 'experience' of the rationalizations that shape the 'history of the present' and not the truth. In that sense Foucault must always be seen as a 'traveller' in the realm of ideas - he had no ready made 'home' (c.f., Hacking, 1998b).

What had always preoccupied him, he declared, was the way in which people in Western societies have experiences that were used in the process of knowing a determinate, objective set of things while at the same time constituting themselves as subjects under fixed and determinate conditions' (1991d: 70). He thought the critical question to be addressed was 'in what is given to us as universal, necessary, obligatory, what place is occupied by whatever is singular, contingent, and the product of arbitrary constraints?' (1984a: 45). He coined the phrase 'limit-experience' (or elsewhere expressed as 'limit-attitude' 1984a: 45) to capture his sense of these processes of subjectification that fashion the politics and practices of modernity (Miller, 1993a: $29 \mathrm{ff}$.). This neologism indicated all those apparent closures of reason that defined, construed and controlled what was possible. This 'analytics' of government considers 'the conditions under which regimes of practices come into being, are maintained and transformed' (Dean, 1999a: 20-21).

The radicalism that inheres in Foucault's work is reflected in his desire to 'de-subjectify' the 'idea of a "limit-experience" that tears the subject from itself' (1991d: 31-32). He wanted to know how we might breach these limitations and what was the:

... relationship between limit-experiences and the history of truth: I am more or less imprisoned or wrapped up in this tangle of problems. I see them better by threading together again certain episodes of my life: what I'm saying has no objective value; but perhaps it can serve to clarify the problems that l've tried to shed light on, and their succession. (1991d: 71)

The concept of 'limit-experience' has provoked various interpretations. For example, Miller, at one extreme, has explicitly tied the concept to Foucault's apparently esoteric sado-masochistic sexual behaviour in some of the gay bathhouses of San Francisco. His interpretation was based on an anecdotal reference of Daniel Defert's (Foucault's partner) that, by itself, does not necessarily substantiate Miller's conclusion (1993a: 398, n. 49). Miller's allusions to the esoteric in relation to 'limit-experience' have been further elaborated by Carrette who praises his interpretations as opening the way for a 'mystical reading of Foucault' in relation to his own theological depiction of Christian 'suffering' (1999: 18-24). Even allowing some licence for Foucault's interpreters, and given the 
imaginative nature of his prose style, such interpretations seem an impossibly long way from what he indicated in his conversation with Trombadori. There he does explicitly locate 'limit-experience' squarely within his depiction of modernity (c.f., Bernstein, 1995).

What he meant by the phrase 'tearing the subject from itself' obviously provoked the interpretive excesses of both Miller and Carrette and led to their idiosyncratic 'reading' of Foucault. However, there is no necessary linkage of his notion of 'limit-experience' to their respective themes. It strains our credulity to argue that what Foucault intended by 'limit-experience' could be associated with either risky behaviour that might incur AIDS infection, or applied to an expression of Christian mysticism involving the passion of Christ. Both represent examples of the 'extreme' application of Foucault's ideas that bespeak their own reflexive presuppositions and ignore what he actually intended. Gutting also accuses Miller of misapprehension and distortion in this specific instance (1994: 23-24), and Halperin, from an analysis grounded in queer theory, is equally dismissive of such wilful misreading of Foucault's thought $(1995,1998)$. The notion of transgression associated with Foucault's concept of 'limit-experience' cannot properly be stretched to fit either Miller's or Carette's more extreme purposes. ii

They miss the vital aspect of his critique of modernity, for both 'limit-experience' and transgression are associated with each other as intrinsic aspects of his deliberations about the nature of critical reflection within modernity. These concepts cannot be appropriated to serve other purposes. For example, Foucault's notion of transgression:

$\ldots$ is not a matter of a once-and-for-all break with a universal and total form of reason, but an 'experimental' attitude that crosses and recrosses the limits of our form of rationality. Transgression, then, is not a residual equivalent of the global emancipation of the subject, but a possibility arising from the work of criticism, an option emerging through trenchant historical and theoretical work. There can be no a priori that favours either transgression or the maintenance of the present status quo. This is a form of critique which uses the knowledge of limits to establish political options without prescribing resolutions. (Dean, 1994a: 54, my italics)

The idea of 'limit-experience' is always associated by Foucault with his investigations into the 'history of truth', which represented, as he said, his lifelong 'tangle of problems' to understand the form of the rationalizations that constitute the present practice of politics within modernity. In this endeavour he forges a new view of history and the 'attitude [of such research] is historical, critical, and experimental, marking a zigzag path at the limits under which the present is constituted for various modalities of 
contemporary experience' (Dean, 1994a: 55). Another indication of what preoccupied him, and which shaped his investigations about 'limit-experience', is revealed in his comment to Ewald about what he meant by his phrase 'getting free of yourself' - similar in intent to 'tearing the subject from itself'. He defined this 'search' as 'opposite to the attitude of conversion' (1984h: 29). It would be idle to read too much into this but it is at least clear that he sought a sense of freedom that was not simply a simulacrum of psychological or intellectual reversal, intrinsic to conversion. His investigations into the 'history of truth' involved the search for a genuine freedom that did not simply resolve the dilemma through complete absorption into the mind-set of another. As Seigel argued:

Like other radical projects, Foucault's was an attempt to define a form of freedom that could escape from and supersede liberal or bourgeois notions of human rights, individual dignity, and subjectivity. His claim to define such freedom through a reinvented form of individuality - antihumanist and modeled on a particular kind of personal experience may be as characteristic of radicalism in our times as Marx's belief that a higher form of individual existence could be found in proletarian community was of his. (1990: 298)

My application and discussion of 'limit-experience' within social policy is allied with Foucault's own interpretations of the processes of subjectification and normalization within modernity. Here it serves an interpretive function as a descriptor of certain political and social practices, the application of particular discourses about 'truth' and reason, and how certain welfare 'populations' are defined and pilloried as dependent sub-groups. What it might mean for social policy to consider that 'peculiar relation' of Foucault's ideas and to evaluate the 'effects they have produced' in relation to the practice and politics of welfare is my central concern. How we apply his ideas must respect his ethical intentions, nowhere more clearly stated than in this reply to Ewald's question about whether he had written his books 'for the liberation movements' when he stated 'Not for, but as a function of our current situation' (1984h: 29).

Keeping the interpretation of 'limit-experience' as a critical reflection on the processes of subjectification within modernity, rather than apply it to the farther reaches of mystical speculation, at least accords with the law of parsimony! As Foucault said, the 'point, in brief, is to transform the critique conducted in the form of necessary limitation into a practical critique that takes the form of a possible transgression' (1984a: 45). Criticism, he thought, can no longer be conducted as the pursuit of immutable formal political structures where such rationalizations have universal application. Such distortions of Enlightenment reason and critique were always a major concern for him since the problem with this line of reasoning, he often argued, is that people espousing these 
'technologies of the reasoned self' are 'posited in Enlightenment radicalism as individuals who have internalized the means of their own domination' (Hindess, 1998a: 60). What we require, he contended, is 'a historical investigation into the events that have led us to constitute ourselves, and to recognise ourselves as subjects of what we are doing, thinking, saying' (1984a: 46). This, in short, is what he means by confronting the rationalizations of 'limit-experience'.

Adhering to his explicit description of 'limit-experience' as an aspect of his critique of modernity, this thesis has two specific personal emphases that obviously establish the pattern of my overall inquiry. The first involves a reflection on the troubled and ineffectual place of normative social theory within contemporary social policy discourse. Social policy, particularly in its theoretical commentary on the politics and practice of welfare administration, has often been criticized 'for its narrow focus and theoretical calcification' (Carter, 1998: 3). The second is a reconsideration of Foucault's oeuvre in relation to new social theory building within social policy. Both of these concerns offer an opportunity to reflect on the place of social theory within a discursive world that 'appears' cosmopolitan and diverse (c.f., Mishra, 1999; O'Brien and Penna, 1998). Indeed even the application of the word 'social' has become 'banal' and we cannot rely on previous valorizations (Rose, 1999: $98 \mathrm{ff}$.). That world is increasingly depicted as a postmodern social world where there is little apparent respect for, let alone reliance on, the grand metaphors and social themes of classic social policy theorists like Richard

Titmuss (1970, 1974; c.f., Bauman, 1997; Dahrendorf, 1995; Leonard, 1994, 1997). Any consideration of Foucault's relevance to social theory must negotiate the shoals of this rhetorical shift in how we apply 'the social' in our politics.

\section{Social Theory, Methodology and Practice}

My investigation of Foucault's ideas in this thesis considers whether social policy can validly use the patterns and intentions implicit in his critique of modernity to develop a new qualitative approach to social theory. That perspective sets the methodological approach in that it is a theoretical and descriptive account of his work and the wideranging and varied reactions he provoked. It is an inquiry that intersects with the philosophical and sociological debates about modernism and postmodernism (c.f., Antonio, 1998; Bauman, 1992, 1997; Flynn, 1989; Hartsock, 1996; Leonard, 1994, 
1997). Silverman has established the importance as well as outlined the problems inherent in such a task. For example, he said that the:

... worst thing that contemporary qualitative research can imply is that, in this postmodern age, anything goes. The trick is to produce intelligent, disciplined work on the very edge of the abyss. (1993: 211)

I will argue, throughout this thesis, that the ability to do this is Foucault's most important and enduring legacy and that he does create new possibilities 'arising from the work of criticism' (Dean, 1994a: 54).

My methodological approach is dictated by this focus on a theoretical consideration of Foucault's ideas in relation to social policy. Some of the ideas that inform my inquiry were developed in a recent book, Social Policy and Risk (1999). In that book I considered, in preliminary form, what influences he had on the theory of contract formulation in relation to discourses of risk and welfare dependency. It explored some aspects of his ideas about the creation of 'expert' discourses of risk and contract through the 'gaze' of medical practitioners within their respective clinics. It examined the processes of subjectification and normalization implicit in the roles of client/patient. These roles were examined as exemplars of the ways in which contracts have become so important an aspect of modernity, namely the measuring and controliing of distinct 'populations' within the nation state (vide Hacking).

The brave new world of 'market warriors' (those who dominate contemporary welfare policy debates) appears to be a ready ground for all forms of argument and debate (c.f., Leonard, 1997; Rose, 1999). It is presented as the fullest expression of the ability to contend within the 'market-place' of ideas. Indeed it often seeks to remove even the possibility of debate in its assurance that 'there can be no alternative' to the dominance of market-based policies of needs ascription and allocation (c.f., Mishra, 1999). But it is actually very constraining in its practice of that which is deemed acceptable, rational and common sense in relation to social and welfare policies (c.f., Fraser, 1989b; Katznelson, 1986; Osborne, 1994). It is my contention that there is an ethical core to Foucault's work that does allow us to reconsider his view of modernity in relation to social policy and apply his ideas to the making and remaking of welfare politics (c.f., Patton, 1984/5, 1994). He does produce 'disciplined work on the very edge of the abyss' of modernity that we can respect and apply to the redrafting of a critical perspective within social policy. 
I have separated this theoretical consideration of Foucault within the social sciences into two main conceptual divisions that are reflected in the structure of the thesis. The first takes as its main focus the complex reaction to Foucault and his ideas. His reception by sociologists, historians and philosophers has been so varied that understanding the nature of that divergent critical opinion provides some insights into how someone like Foucault, who clearly straddles these academic disciplines, is received. It also acts as a reflective counterpoint to how radical ideas are debated and assessed within the practices and epistemological 'limits' of contemporary criticism. The second applies this investigation of his ideas to social policy theory. The question is whether social policy can generate a new critical perspective that might mount an effective challenge to the hegemony of welfare policies that currently are determined by an ethos of market-based rationalizations and solutions.

Since social policy and sociology are so intertwined, considering Foucault's reception first within the discipline of sociology sets the scene for how a more detailed examination of him might be made in relation to social policy theory. The social sciences ought not to focus on defending Foucault. We do not need to recuperate his 'work for philosophy, history or the social sciences'. What is required is that we undertake 'a form of analysis concerned with the limits and possibilities of how we have come to think about who we are, what we do, and the present in which we find ourselves'. Social science theorists can use Foucault, as Dean continues, 'to form or reform ourselves as philosophers, historians and sociologists', but they can also 'use Foucault to inaugurate a critical engagement with our present, with its limits and its practical potential' (1993b: 18). Inaugurating a 'critical engagement' of social policy with Foucault at the level of theory building is timely. The following synopsis provides a description of the chapters as well as an overview of the particular approach taken in each of them.

\section{The Plan and Synopsis of the Thesis}

After this introductory chapter I will discuss the place of Foucault within the fractious modernist/postmodernist debate, and relate the various 'claims' that he was a postmodernist to my focus on social policy. Foucault, I will argue, stands squarely within a modernist tradition, his 'fight' being more often with Marx and Freud, but he is also adduced as a precursive philosopher of postmodernism (Foucault, 1991d; Hewitt, 1994; Raulet, 1993). I will, however, argue that this is a wilful misreading of him. 
There are ongoing problems about how to interpret Foucault, the extent and range of which provide new insights into the nature of late modernity and all its 'discontents' (c.f., Bauman, 1997; Descombes, 1987; Fox, 1998; Pavlich, 1995; Szakolczai, 1998b). The third chapter reviews all the various attempts of philosophy and sociology to 'capture' or 'explain' Foucault. It considers questions about his famous aloofness, his attack on the function of the 'author', his famous arguments about the 'death of Man', his writing in order 'to have no face' (1977a) and why it is that he still 'troubles' as well as informs critical reflection. His intransigence at being 'explained' and 'owned', rather than 'experienced', provides a particular perspective on what it means to claim 'knowledge' or 'truth' (1977a; 1988d). This dispute about the various 'Foucault's' provides some insight into the status of critical reflection.

Having reflected on the various 'Foucaults', and what the search for such singular explanations of him might indicate, the fourth chapter narrows that discussion and surveys the critical oscillation in the assessment of Foucault (often polarized) as revealed in various reviews of his major publications. This chapter brings together some original material only partly hitherto assessed by Macey (1993) and Miller (1993a) in their respective biographies. Scanning the range of problems that many reviewers had in 'locating' Foucault, the abrupt dismissal of him, as well as the rapturous reception he received from others, provides a valuable perspective on his ability to disconcert and challenge prevailing ways of thinking.

The fifth chapter narrows the focus of the debate by highlighting the discussion on the theoretical importance, for sociology and social policy, of Foucault's later work particularly his theory of governmentality. This chapter considers the nature of the sociological objections to his ideas and reviews the substance of that critique. There are many significant references that deal with this aspect of Foucault's thought and the following are ones relevant to my thesis (c.f., Barry, Osborne and Rose, 1993; Burchell, 1991; Dean, 1999a; Donzelot, 1991; Foucault, 1991c; Garland, 1997; Gordon, 1991; Hacking, 1986c; Hindess, 1997a; O'Malley, 1999; Procacci, 1991, 1994, Rose, 1996a, 1996b, 1999; Stenson, 1999a, 1999b; Turner, 1997). In this very important theory, which has spawned considerable ongoing debate, Foucault observed that whereas previously sovereign power operated on internal self referent and autonomous action, 
contemporary government relies more on the management of public opinion and the search for more persuasive 'tactics' (1979: 13; c.f., Hindess, 1996b).

The sixth chapter extends this analysis of the governmentality literature and re-examines Foucault's important lecture On Governmentality. It discusses how this lecture opens an interesting inquiry about the policies and practices of government in relation to risk, social welfare and dependency (c.f., Fraser and Gordon, 1994a, 1994b; Taylor-Gooby, 1993). The new 'language' of risk, and Beck's thesis of risk society (1992), construes not only the validity of the discourse about welfare but shapes the very domain within which discourse is possible (c.f., O'Malley, 1996, 1999). This chapter reviews the debate about the 'humanist-turn' in Foucault's ideas (his focus on the subject) and discusses the criticism that his position about the nature of Enlightenment Reason precludes any application of his ideas in critical social policy theory.

The seventh chapter considers the value of Foucault's overall oeuvre in relation to social policy and how we are 'governed thus' (c.f., Pavlich, 1995). It examines the major shift in welfare policy and practice indicated in the discursive and practical realignment of our politics - from a welfare state to a welfare society. How what was previously 'social security' (the former welfare state) has been refashioned into issues of individual risk management and security within a commodified market society (the new welfare society) is a fascinating aspect of the changed discourse of welfare. The question of whether the welfare state could be described as an ethos, institution or project is discussed, as is the impact of globalization and its bearing on social policy.

This application of 'ethos' expresses the same set of ideas that the welfare state is best described as government from the social point of view (Rose, 1999: 130; c.f., Procacci, 1989). The chapter further examines how risk discourses applied revamped notions of security to deconstruct the previous justifications for welfare. The final chapter returns to Foucault's imaginative use of Nietzsche's phrase that the state is the 'coldest of all cold monsters'. The shape and nature of the future discourses about welfare, risk and social policy are outlined. Brief mention is made of the changes that mapping the human genome will bring to bear on future welfare governance. The hope is expressed that we seek to use our conflictual analyses of risk to reveal ourselves to ourselves, and not attempt to eliminate this conflict (Donzelot, 1991: 178). 


\section{The Contested 'World' of Social Theory}

Whatever the respective merits of the debate about modernity/postmodernity it is clear that there has been a relative eclipse of both social democratic traditions and the emergence of a 'post-welfarist regime of the social' (Dean, 1999a: 207). There is a conceptual weakness in social democratic theorizing that renders it ineffectual in the face of the dominance of neo-liberal politics (c.f., Hindess, 1998b; Mishra, 1999; Rose, 1999). The field of social policy has oscillated from an empirical positivist tradition, arguing for the social and political recognition of human need and distress, to a more diffuse depiction of 'grand design' social theories supporting a social democratic visions of political betterment (c.f., Barry, 1997; Dean and Melrose, 1999; Esping-Andersen, 1996; Offe, 1996; Saunders, 1993; Taylor-Gooby, 1993).

Welfare and social policy theory building, expressed as the depiction and defence of social need and entitlement, has not been overly interested in critical social theory as such. For example, Glennerster famously declared that social policy writers should worry less about critical theory and concentrate more on 'clearing people's rubbish' and that this would serve humanity better (1988: 84)! The question is whether social policy theorists can justifiably seek to apply Foucault's ideas when arguing for an effective critical social theory (c.f., Burchell, 1996; Fox, 1998; Hewitt, 1983, 1992; Hillyard and Watson, 1996; Leonard, 1997; Lloyd and Thacker, 1997; Osborne, 1994; Squires, 1990 , 1992).

The rhetorical genius of neo-liberal thought has been to present an attack on the old welfare state consensus couched within powerful and compelling slogans, for example, the 'death of the social' or the triumphant 'revolt of the individual tax-payer' or the requirement that we all be 'active participants' in a market driven world (c.f., Fraser and Gordon, 1994a, 1994b; Heclo, 1994; Loney, 1987; Mishra, 1999; Rose, 1996a, 1999; Stenson and Watt, 1999). The eclipse of the social democratic welfare state was presented as if it were a modern climax and ultimate resolution to the age-old debate between the individual, the social and the state. Baroness Thatcher in one of her most [in]famous anecdotes stated that there was 'no such thing as society' (Thatcher, 1993: 626; c.f., Dean, 1999a: 151-153; Kingdom, 1992). 'Killing off' the social became a catch-cry of an energetic individualism that rejected any notion of social obligation, for it was now the market alone that could secure the world against the worst excesses of any 
socialist incursion! It assumed that the power of the 'one' over the 'many' had finally been established (c.f., Hirst and Thompson, 1995; Huber at al. 1997). When Baroness Thatcher also coined the companion phrase that 'there is no alternative' (TINA) to the logic of market-place transactions she appeared triumphant in dealing closure to this age/old debate. iii

So rampant was this new politics that it was seen, by some, to usher in 'the end of history' (c.f., Fukuyama's The end of history and the last man, 1992; Megill, 1979, 1989) and to set the market as the only real arbiter of worth, wealth, success and value. Mishra argues that what 'accounts for the astonishing élan and verve of a free market utopia seeking to further its hegemony' is due to the 'collapse of communism and the absence of any systematic alternative to a market economy' (1999: ix). However, the issues between the 'one and the many' underpinning modern political debates (Foucault, 1981b) have long marked out the ground of political ferment. Despite a new cut to the debate it is unlikely that we can so easily assume 'an end to history'. As Scott tersely, but validly, concluded 'After history? History!' (1996: 26). Foucault never assumed that it was possible to resolve that dilemma. It represented the enduring 'welfare state problem' of how to adjust 'political power wielded over legal subjects and pastoral power wielded over live individuals' (1981b: 235).

How we define our political moralities, opportunities, values and goals will always refract the intricate relationship between individuals, society and the state (c.f., Shklar, 1989; Young, 1990, 1996). We must pick our way through the complex patterns that emerge as we make sense of our personal lives and the particular social arrangements within which we live. Some of this we can shape for ourselves, some of it is the 'paramount reality' that we can neither shape or much affect. In some ways it represents one more spin of the old conundrum between the possible and the necessary. How we deal with the necessary, the sometimes brutal and indifferent social 'fact' - the randomness and capriciousness of the market - provides an opportunity for the possible.

The idea of the social represents this awareness that our personal and social relations cannot be solely subsumed within the 'iron-fisted' logic of the market (c.f., Fraser, 1989a, 1989b). We formulate our unique responses to life, claim our own particular excitements, and engage in the defence of our personal privacy by participation with 
others in a social context that is the ground of political choice. To argue, as social policy theory does, for the legitimacy of the social and 'society' is to contend that there is a realm of public life within which there remains the possibility of mutual discussion and understanding free of coercion and manipulation.

However, because of the strength of the neo-liberal challenge social policy theory is drawn into a defensive stance whereby its traditional reliance on models of grand social planning could only lead it into a cul-de-sac of normative assertions (c.f., Hewitt, 1992, 1994; Mouffe, 1992; Squires, 1990). When neo-liberal politics asserts that there is no such thing as society it takes aim directly at this concept of a public service ethos that sought to stand apart from political and market transactions (c.f., Baudrillard, 1993; Procacci, 1991, 1994; Rose, 1996a; Stenson and Watt, 1999). The concept of the social that this ethos embraced implied 'the minimal, necessary conditions for a discursive realm free of coercion or manipulation' (Johnson, 1994: 427). It represents that belief in an arena of philosophical and political discussion neither coerced by specific policy assumptions nor relentlessly manipulated by the 'hidden hand' of market mechanisms.

Defending the presumed 'sanctity' of this 'public sphere' social policy has become trapped within an encompassing rhetoric - an epistemology of the 'ought' or 'what should be'. Neo-liberal welfare theory and administration is grounded in the new contractualism that argued for the relative privatization of welfare. Any possible future argument, one that represents a particular reliance on the social - on the idea that there can be some valid attribution of and call to mutual obligation as the ground of our particular social supports - will require a different rhetoric (c.f., Fraser, 1995a, 1995b, 1997).

Contending with neo-liberal assumptions that 'there is no alternative' requires new initiatives; new ways of thinking and new models to challenge or subvert neo-liberal patterns of thought (Maclntyre, 1988: 401). Public service restructuring reflected the new managerialist themes of public choice theory, agency theory and transaction cost analysis (c.f., Boston, et al. 1996; Culpitt, 1999). My concern in this thesis is to see how durable the rhetoric of principal, agent and contract may be. What would it mean for social policy if we could determine implicit aspects of neo-liberal policy that were not grounded in a defence of individualism and a minimalist contract state? 


\section{Can social policy mount an effective dissensus?}

Social policy no longer has command of a rhetoric that can galvanize political and public opinion. The moral gravity of Titmuss, in writings such as The Gift Relationship, which established an intellectual position for an independent social policy theory, remains but seems rather an echo of a 'social' world that has been superseded. In this, arguably the most famous of his books, he set out to dispute the 'philistine resurrection of economic man in social policy' (1970: 14). He suggested that social policy must be concerned with the 'unquantifiable and unmethodical aspects of man as well as with those aspects that can be identified and counted' (1970: 224). Titmuss' intent was to invite consideration of the assumption that anonymous voluntary gift giving elevated us all and would serve to overcome individual alienation. This is a curious precursor to some of the subsequent 'Thatcheresque' assumptions about voluntary support of welfare systems (1993: 626; c.f., Dean, 1999a: 151-153; Kingdom, 1992). It was an eloquent manifesto for social obligation. His conclusions, about the risks associated with a comparative analysis of American and British blood donors, are that altruistic concerns 'derive from our own characters and are not contractual in nature ... [and that] it is these concerns and their expression which distinguish social policy from economic policy' (1970: 212).

The rhetorical power of those arguments that collapse the distinctions between economic and social policy, so central to the initial rhetoric of welfare states, needs to be respected. Social policy theory that cleaves to a simple juxtaposition of the venality of the market and the morality of social justice concerns will have no sway in the contemporary redrafting of welfare states into welfare societies (c.f., Le Grand, 1997). iv This is not to deny the place and the power of such distinctions in the history of social policy thought. For the moment, however, attempting to resurrect them as the mainstay of contemporary debate condemns social policy to marginality. The dominance of the neo-liberal, deregulated contract state, with its emphasis on market-based solutions to the distribution of social goods, has collapsed the force of this previous distinction. The paramount reality is competition and risk (c.f., Beck, 1992; Hindess, 1998b; Mishra, 1999; O'Brien and Penna, 1998; O'Malley, 1996, 1999). 
Increasingly public sentiment decries interventionist governing except in times of major crisis. Railing against the 'blitzkrieg' speed of these public sector reforms, or decrying their 'philistine' intent, is no substitute for trying to understand the force of the intellectual imperatives that uphold them. While there is an anti-bureaucratic and anti-biggovernment strain to neo-liberal thinking one of the paradoxes of the application of neoliberal welfare policy is that it actually strengthens the centralizing functions of the state (c.f., Rose, 1999). As Pratt argues, the application of these policy agendas:

... does not mean, then, that the state fades from view altogether. Indeed, in certain respects it has been prepared to centralise more power in itself ... setting national objectives and standards for public organisations such as universities and the criminal justice bureaucracies that must be adhered to, to ensure that its objectives are not undercut or challenged, or that new rules for government that it has set in place are not subverted by individuals or institutions with vested interests or differing political agendas. (1997: 135)

If social policy theory remains yoked to rigid articulation and defence of a normative epistemology in support of traditional welfare systems - promoting the rhetoric of what ought to be rather than to an analysis of what is - then it will remain isolated and marginal (c.f., Hewitt, 1992; Mink, 1994).

We will make no progress in this debate unless we approach the eclipse of such social arguments from a new perspective, one that stands apart from the rigid polemics surrounding the change itself. The critical task is to understand the fundamental constraints built into how we say that we know the world. Knowledge that only establishes a normative critical perspective is no longer effective. It is not knowledge towards something else (obligatory injunctions) that can advance the debate. Knowledge and reason, for Foucault, can have no valid teleological intent only knowledge of and about knowledge - hence his focus on practices and patterns as 'limit-experiences' that shape modernity.

Thus critique, for Foucault, 'is the movement by which the subject gives himself the right to question truth on its effects of power and question power on its discourses of truth' (1997a: 32). It emphasizes process, patterns and practices not magisterial and compelling certainties. Critique means finding the discursive ground on which to challenge neo-liberal rationalizations whereby contingency is ignored and equal debate denied. 
Consequently, the rhetorical and 'packaged' certainties, that allowed neo-liberal policies to be promoted as the only viable political 'game in town', need to be revealed as discursive practices and not ineluctable 'truths'. How the 'truths' of common sense policy rationalizations are enacted does typify 'effects of power' - well expressed in Foucault's phrase 'the least glimmer of truth is conditioned by politics' (1990: 5). His view of truth does not involve ways to discern truth per se but that we describe the 'procedures, proceedings, and processes' involved in willing it (Deleuze, 1995: 117). He was 'adept at reorganizing past events in order to rethink the present. He engagingly turns familiar truisms into doubt or chaos' (Hacking, 1981: 32).

Similarly, power, for Foucault, never resided or could be contained within its particular expressive form. It was not 'owned' by particular dominant groups and could not be explained hierarchically. He had a 'predilection for 'how' questions, for the immanent conditions and constraints of practices' (Gordon, 1991: 7). He was interested in the 'how of action' - the mass of shaping and defining 'practices'. So the critical challenge is never to particular political groupings, per se, as if power resided in their facticity. His core argument was that knowledge/power is both capillary and ubiquitous (1980a: 89). Power was always more omnipresent and dispersed, it can neither be 'given', 'exchanged' or 'recovered', only exercized. " Consequently, he argued that power 'exists only in action'; in the manner of its 'doing'. Examining the 'practices' of our current social dispensations, the actuality and not the why of them, provides a pathway away from the 'seductions' of grand design theory.

\section{Reprivatization and the 'Death'/Eclipse of the Welfare State?}

The former injunctive and 'magisterial' arguments that supported initial patterns of welfare state rhetoric are no longer persuasive. There has been a 'sea-change' in social ideas - from a welfare state to a welfare society - one that is breath-taking in its hegemonic compass. One public management theorist, who set out one of the more influential arguments depicting an administrative 'crisis' in the old welfare state, that prompted the push for a welfare society, was Peter Drucker (1969). The neo-liberal reforming principles that support the dismantling of the public sector bureaucracies, and introduced new contractual managerial performance measures, have dominated New Zealand's public sector management since the fourth Labour government in 1984 . vi There are many intellectual precursors for these changes but one of the most interesting 
sets of arguments justifying this dramatic revamping is expressed in Drucker's 1969 paper 'The Sickness of Government'. Here he set out some arguments for 'reprivatization' - the type of public sector restructuring which we have witnessed since 1984 - that provided much of the intellectual impetus and rationale for these public sector reforms.

There are some key assumptions imbedded in Drucker's paper that highlight the imperatives that guided New Zealand's public sector reforms - reliance on contracts and the rigorous application of agency theory. Agency theory argues that our social and bureaucratic arrangements will be more efficient when they are based on clear enforceable contracts between a principal and an agent rather than on the old ethic of 'public service' obligations and allegiances. vii In this view the public service is better constructed as a tiered hierarchy of contractual arrangements ranging from Ministers of the Crown downwards. Drucker thus argues that:

- All institutions should be autonomous. They should, he suggests, be reduced to their 'core business' activities.

- All social structures would have in common 'a principle of performance rather than a principle of authority'. That is that they be based on contracts between agents and not on some amorphous ideology of service that reflects a certain ethical authority but no measurable performance criteria.

- 'Reprivatization' substantiates arguments for contracted social and health services rather than universal provision.

- 'Reprivatization' denies that the private individual market and public communal world are intrinsically antagonistic and separate.

- He suggests that economic choices should follow the basic assumption that we need an 'organic diversity in which institutions are used to do what they are best equipped to do'. (1969)

Throughout all of the complex rationales for political and social restructuring, based on 'more-market' principles, run the threads of his argument that analysis of social policy is best derived by a principle of performance rather than one of authority. Support for principles of 'reprivatization', and the pre-eminence of performance over authority, is echoed in the pattern of the welfare paradigm shift from that of structured and responsible authority to the legitimacy of sectorial interests and rights (c.f., Culpitt, 1992).

There is an important paradox at work here. When social justice claims-making remains stubbornly normative, clinging to a 'false nostalgia' for those institutions that have been so powerfully socially deconstructed, the innately defensive rhetoric of individualism is reinforced. In the current policy climate such normative claims, even when 
acknowledged, are quickly dismissed, and are not engaged with or much debated. To re-establish an effective 'voice' for social policy requires that we enter the debate and not stand outside it. However, the typical concerns of social policy were not always normative (c.f., Esping-Andersen, 1996).

The traditional concerns of social administration in the Titmuss oeuvre, for example, had been strongly empirical and positivist. The stubborn growth of social need and demand, within Western economies that were recasting their economies towards service-based and globalized models, undercut these traditional arguments for a social democratic political economy (c.f., Beck, 1997b; Deacon, 1997; Hindess, 1998b). The increasing financial demands required to meet an ever-expanding social need was considered too burdensome for national budgets (c.f., Esping-Andersen, 1996; Offe, 1996). From these economic analyses and assessments arose all the arguments for cutting back public bureaucracies and ushering in the 'minimalist state' (c.f., Boston et al. 1996)

Social justice models, that empirically demonstrated the legitimacy of social need, became side tracked and were ineffectual in delivering any challenge to the neo-liberal dominance of public sector and financial policy. We need to understand the power of the neo-liberal political rhetoric (typified by Drucker's thesis) that so swiftly captured the public policy debate during the 1980s and established rationales for the deregulation of the public sector welfare and health bureaucracies. Overturning these bureaucracies, that had institutionalized social security, swept away the former justifications for welfare states. The drive within social policy to strengthen theory led away from the patient presentation of detailed accounts of policies and services, as they exist.

Neo-liberal social policy ignored such empirical studies in support of various social needs (the 'raft' of shelved social impact studies, for example) and scuttled them by an emphasis on pragmatism. viii Rather than deal with questions of social justice or social obligation these reports, social surveys and policy debates were relegated to the technical issues of fiscal probity alone. This process has often been depicted as the 'affordability crisis of welfare' (c.f., Hindess, 1998b; Offe, 1996; Taylor-Gooby, 1993). The rhetorical ground for political and public sector administrative debate had shifted. 
The study of the governmentality of welfare 'takes it as axiomatic that government is a 'problem-solving activity' and 'tends to conceptualise these problems and fields through the perceptual grid of the programmes and rationalities that the authorities generate to deal with them' (Garland, 1997: 200-201). This emphasis on the tasks of government as problem-solving activity undercuts any argument that these issues of how we are governed might be examined independently. Neo-liberalism thus stands apart from any evaluation of the normative debate and insists only on the relevance of practical and manageable solutions. Part of the appeal of neo-liberalism was that its political plausibility lies in the claim that the market, if given free rein, limits the persuasive power of ideology' (Hewitt, 1992: 40).

The apparent excesses of social justice claims-making, typical of the previously dominant welfarist epistemology, are either relegated to the past or projected out into the future (Dean, 1999a: 171-175, c.f., Drover and Kerans, 1993). So much so that the current era in welfare policy debate is described as 'a post-welfarist regime of the social' (Dean, 1999a: 171). These old welfarist imperatives are seen either as the remnants of a defeated former socialist perspective, or as possible future goals, only feasible as a by-product of a strong economy. In either case, such rhetoric depends upon the manner in which the practical and common sense are subsumed within the 'frame' of managed risk.

The structure of that dominance depends upon the use of definitions of social life that are appealed to as basic and incontrovertible. Typical of such rhetoric is the expression of an instinctive pragmatism. The gist of these basic assumptions, from public choice theory, is that people are primarily selfish; they are presumed to be 'rational utility maximizers', ix and are better equipped themselves to rank order the priority of their needs (Reddy, 1996: 234). Similarly, it is argued that only through clear specification of contracts - the mechanism of purchaser/provider split - and by applying the reward system of agency theory can the true nature of market exchange be realized. The rhetoric of liberal deregulation depends upon an assumption of obviousness. What is being created in our economic and social exchanges can derive meaning only from what is, not from what ought to be. ${ }^{x}$ This is not to argue that neo-liberal social policy has no vision of the future in respect of welfare and social policy discourses but that it is inevitably constrained by an excessive focus on the pragmatism of market-place 
solutions. If social policy is about what we do, setting out the actions taken to deliver certain sets of political and social assumptions, then examining the patterning of these governance assumptions may yield a renewed defence of the social.

Reconsidering the pattern of these assumptions has led me to consider how relevant Foucault's thought might be to the task of challenging or subverting the particular dominance of neo-liberalism within current debates about what are effective and achievable social policies. His thesis that with 'the new techniques of subjection the 'dynamics' of continuous evolutions tends to replace the 'dynastics' of solemn events' (1979a: 160) established a new way to understand the place of normative argumentation. He contrasted the rigid imperatives that support universal welfare policy prescription (defined as dynastics of solemnity) while still alluding to the disciplinary and control aspects implicit in a new focus on experimentation and 'evolutionary dynamics'. $\mathrm{He}$ would never allow for a simple analysis that would divide the functioning of knowledge/power in policy formation and practice (c.f., Garland, 1997). If social policy remains caught within an epistemology of the social that can only discuss its concerns within a magisterial rhetoric (Foucault's 'dynastics') then it cannot contend dynamically with the constant and dynamic 'chatter of politics'. It will have no tools to reflect on 'failure' as an intrinsic aspect of governance (c.f., Malpas and Wickham, 1995).

\section{Welfare Discourses: Some Preliminary Comments}

The discourses of welfare, at least insofar as they relate to some form of State responsibility, have been variously shaped and debated since the original legislation adumbrating the Elizabethan Poor Laws. The distinction between the 'deserving' and 'the undeserving poor' has almost become a maxim of public discussion about eligibility for social assistance. There is nothing intrinsically contemporary about anti-welfare discourses. What kind and level of assistance to provide for the deprived and the 'unsuccessful' has been salient in the shaping of modernity and the formation of the nation state.

My emphasis is more explicitly on how the negative aspect of this long held descriptive dichotomy of 'deserving and undeserving' has been sharpened within neo-liberal discussions of welfare. When he set out to describe his ideas about how we might apply new analytical tools to analyze such discourses Foucault located this task within his 
fundamental aim to mount an effective challenge to current intellectual hegemonies. $\mathrm{He}$ rejected any form of reasoning that depended on a teleological trust in transcendent universal human themes, and he deprived the 'author' of any objectively central place in these analyses. There is an old/new dichotomy to such studies but my contention is that neo-liberal discourses about risk have served to shape the power of the current rhetoric that sees a return to the themes of blaming and shaming.

The idea that neo-liberalism has re-established the 'truth about politics' in reaction to the presumed aberration of the welfare state reflects a particular aspect of that discourse which needs examination. We need rather to see, as Foucault suggests, "how effects of truth are produced within discourses which in themselves are neither true or false' (1984b: 60). The search for a former truth and its reinstitution sets up patterns of action regarding certain key ideas. For example, it establishes that the functioning of discursive regimes essentially involves forms of social constraint' (Fraser, 1989b: 20). Whatever the rhetoric, the patterns of constraint instituted to express these dominant ideologies may reveal how power is really exercized. Fraser suggests that:

... the valorization of some statement forms and the concomitant devaluation of others; the institutional licensing of some persons as authorized to offer authoritative knowledge claims and the concomitant exclusion of others; procedures for the extraction of information from and about persons involving various forms of coercion; and the proliferation of discourses oriented to objects of inquiry that are, at the same time, targets for the application of social policy. (1989b: 20)

The pejorative assertions about the problems of welfare dependency, and arguments for eliminating the 'passive' welfare state and establishing 'active' welfare societies, can be evaluated against these valorizations. The task is not just to untangle these patterns of belief but also consider how current assumptions about 'power/knowledge' (to apply Foucault's term) establish certain forms of 'institutional licensing'. For example, how the idea of risk permeates the creation of these new patterns of power and sets new standards for how to respond to and evaluate both need and dependency. Fraser argues that the 'formation and functioning of incommensurable networks of social practices ... [involve] the mutual interrelationship of constraint and discourse' (1989b).

That revaluation of risk within neo-liberalism depends upon discourses about constraint. For this reason questions about the patterning of this constraint are more useful than continuing 'slanging matches' about the 'new right' and public choice theory being an outmoded philosophy of individualism. Effective analysis needs to move past the frozen 
rhetoric of either individual or community bantering. We deliver welfare services in precise ways because it suits us to do so - in order to maintain discourses of access that keep salient the more fundamental discourse about risk. These new risk discourses have removed 'security' from the social and aligned it with independence. Attacking welfare dependency is thus revealed as an essential prop to the more fundamental perception of risk as threat, rather than happenstance - which is the bedrock of the neoliberal position.

The other aspect of this discourse, which needs unpacking, is the notion that 'communities' of autonomous individuals can and should be governed through consent of their members. Processes by which welfare clients are 'disciplined' on account of their dependency are hidden in this notion of governance through consent (Dean, 1995: 567; Hindess, 1997b: 24-25). To enjoin the same acceptance of risk responsibility of welfare recipients is to invite them into the singular vision of neo-liberalism. Countering implicit aspects of such analyses requires careful articulations of difference. It also requires us to see the implication of Foucault's manifest paradox that the history of such discourses (about apparent mutual consent) represents 'a set of specified and descriptive forms of non-identity' (1991a: 62). Generalized welfare discourses create a disdained 'population' that has no specific individual identity. They reflect the subjectifications and normalizations of welfare 'limit-experiences'. Challenging the power of such social 'discrediting' depends upon making explicit the implicit aspects of such generalized and apparently obvious welfare discourses. We need, as Beck argues, 'an eye for the rule-governed character of what is apparently, natural ... so that the train of argument and action will travel in the opposite direction' (1995a: 171).

Relying on the political metaphors of the past will not assist us to understand the real reasons for the dominance of neo-liberalism. If it is the case that the demand that politics and policy respect an irreducible individualism cannot be tightly linked to the past, then we may turn to an analysis of risk in order to highlight the essential aspects of this new but not old right. It is the argument that individuals must accept responsibility for dealing with risk that has helped shape the anti-welfare lobby. While this needs to be described as a set of beliefs, there are limits to this form of exegesis. Epistemological analysis will only take us so far. Revealing hidden meanings has not proved an effective strategy so far in challenging the dominance of neo-liberalism. The anti-welfare 
discourses of neo-liberalism are not easily amenable to argument. Those sets of ideas about the 'perils of welfare dependency', the failure of the state as a 'guardian of our best interests', the absolute requirement for tax reductions and a 'minimalist state' have become resolute modern mantras.

What has brought about this sea change in an acknowledgement of legitimate social need? The crisis of affordability is an important strand in seeking answers to this question. These arguments are discussed, not just as if they had a coherent internal logic, but in the context of the changes that we see in how the individual interacts with and relates to the state. As Foucault suggests, the political power of these discourses depends not so much on the espoused systems of belief but on the actions and processes engendered by these beliefs. Epistemological challenge does not reveal action and debate process. Focusing on welfare practices and not ideologies raises the following questions:

- What are the imperatives of 'tribal' knowledge that are revealed in the new social movements?

- Can we have a legitimate separate or 'tribal' knowledge in a world increasingly globalized?

- What unique 'knowledges' are possible for us in the new risk society?

- Does neo-liberalism represent an expansion of a political logic or a constraint and contraction into the solitary perception of individual risk?

- What are the institutional and managerial forms of how power is exercized and legitimated that alter, not only our beliefs, but also how states must practise welfare?

- What does it mean for states to define the proper role of the individual in terms of managing their own risk?

- Why has 'being dependent', previously part of the natural cycle of life, become so pejorative?

- How has the very notion of 'welfare' become so derisory?

Answering these questions requires a dual focus - on the sets of normative ideas but also on the practice of these ideas. It will be important to join Foucault in refusing to place the notion of a power, which is based on consent, at the centre of an analysis of government. He argued that 'the idea of a sovereign power based on the consent of its subjects should be regarded simply as one rationality of government amongst others that are at play in contemporary societies - and as one that need be accorded no special analytical or explanatory privilege' (Hindess, 1996b: 145). Neo-liberal reliance on 'governance through consent', which sustains an attack on social risk management formerly assumed through systems of social security, can be critiqued as a specific instance of welfare 'limit-experience'. 


\section{Foucault's 'Subverting' of Knowledge}

Foucault famously declared in the epigraph at the beginning of this chapter that the point of philosophical activity involved the endeavour to know how and to what extent it might be possible to think differently - to examine the functioning of such 'limit-experiences'. This reconsideration of his ideas from a social policy perspective will not necessarily yield a new compelling normative rhetoric but it will provide an opportunity for us to think differently about the taken-for-granted nature of so much social policy theorizing. We do need to think differently or at least to see if it is possible to do so. Imagining difference, strategizing for it, and welcoming it, mark us out as constantly restless - a personal style that Foucault embraced with some gusto (c.f., Macey, 1993)!

This thesis represents one set of reflections about Foucault in order to see if his ideas might still be useful in 'thinking differently' about social policy - to construct a different 'chatter'. As Garland suggests, some of his concepts developing from his analysis of governmentality 'are neologisms ('bio-power', 'pastoral power' 'governmentality'); [while] others are historic terms ('police', 'raison d'etat')' (1997: 193). That he 'resists' any new paradigmatic use of his ideas raises some cautions in an uncritical application of his ideas to sociological and social policy analysis (Garland, 1997: 193-194). Osborne, similarly guarded and even more doubtful, scorns an over-reliance on Foucault's wellknown theories of power, discipline and the Panopticon (1994: 485). Any effective future application of Foucault's ideas will have to move carefully past a zealous application of the 'carceral society' (c.f., Lacombe, 1996). As Osborne argues, 'if there is a utility-value for sociology in Foucault's work, it comes not from a passive 'application' of his thought but rather by way of a broad re-channelling of existing themes' (1994: 488). Osborne argues that neo-liberalism avoids any possible loopholes in its discursive certainties about welfare by focusing only on the technical issues of policy implementation - a 'kind of governmental anxiety-made-technical' (1994: 488; c.f., Rose, 1996b).

Foucault's work may help to identify these themes but we have first to understand something of the 'meaning' he gave to his work, his place within the debates about modernism/postmodernism, and the vastly polarized intellectual opinion about his relevance to these debates within social policy. Applying his concepts indiscriminately will obfuscate rather than enlighten. We cannot easily look to him for paradigmatic or normative 'answers' but we can examine his ideas to enlarge our own sense of what it 
might be to think differently about social policy. Despite the obvious potential for confusion his ideas do provide a unique perspective from which to examine the disciplinary and governance functions of modern welfare and social policy. However, this examination is no intellectual hagiography (c.f., Halperin's Saint Foucault 1995) but places itself within the whimsical yet acute observation of Hacking:

Foucault carved numerous turns of phrase into ice-sculptures, which had, for a moment, sharp contours. Then he walked away from them insouciant, and let them melt, for he no longer needed them. His less gifted readers put the half-melted shapes in the freezer and, without thinking, reproduce these figures as if they still glistened in the midnight sun and meant something. (1998b: 85 )

One particular example of this was the way Stanley Cohen seized upon Foucault's phrase from Discipline and Punish about the 'punitive city' and 'hundreds of tiny theatres of punishment' (1979a: 113) and built his critique about social control and modern criminological studies on the tantalizing threads of that allusion. Cohen's was an influential but quite mistaken reading of Foucault. One of Hacking's 'ice-sculptures' perhaps? Bottoms challenged Cohen's uncritical and mistaken reliance on Foucault's imaginative discussion of a 'disciplinary society', since, as Bottoms reminds us, 'the punitive city' was in fact a reference by Foucault to pre-disciplinary penal arrangements in the early $19^{\text {th }}$ century, not a consequence of modern disciplinary power itself.

In my recent book Social Policy and Risk (1999) I invited a discussion about whether the pre-eminent political philosophy of neo-liberalism could be challenged applying an analysis of the discourse and function of risk to such anti-welfare rhetoric. That task drew heavily on an application of Foucault's ideas within a new critique of social policy theory. 'Locating' Foucault within a sociological framework and explaining his importance continues to exercize considerable critical reflection (c.f., Dean, 1994a, 1994b; Fox, 1998; Osborne, 1994, 1998b; Pavlich, 1995; Szakolczai, 1998b).

Reflecting on the patterning rather than the polemics of rhetorical and historical change, as well as denying the teleological logic of Enlightenment Reason itself, earned Foucault a particular 'notoriety'. Considering the patterning of this critical acclaim provides a specific opportunity to assess the conundrum - how to find within social policy an acceptable language for critical reflection. I will examine the nature of the critical as well as the positive reception of his ideas, and offer some commentary on how Foucault presented himself as well as his thought. As we shall see he can be used within social 
policy to support diametrically opposite conclusions. How such conflicts and interpretations arise provides a valuable reflection on the use of critical theory in our contemporary world.

Foucault has had a remarkable impact on the style of intellectual debate. For some, of course, he is a villain, recondite, elusive and ultimately irrelevant (c.f., Fox, 1998; Merquior, 1985; Taylor, 1986, 1992, 1995). For others, he has touched on the elements of how we have 'made ourselves how we are' and therefore how we might unmake that which we take to be immutable (c.f., Bernauer and Mahon, 1994; Halperin, 1995; Hiley, 1988; Moussa and Scapp, 1996; Veyne, 1993, 1997). What Foucault offers us in relation to social policy is altogether more elusive and fragmentary, but precisely because of that his ideas have power to compel and illuminate.

We do need to understand the political function of taken-for-granted certainty - all those 'truths' he questioned. But always mindful of his own ironic (and self mocking) assertion that:

Folly also has its academic pastimes; it is the object of argument, it contends against itself; it is denounced, and defends itself by claiming that it is closer to happiness and truth than reason, that it is closer to reason than reason itself. (1965: 14)

How social policy theory has operated within such immanent 'givens' of Enlightenment Reason has been the focus for the development of a small but important body of social theory within social policy (c.f., Hewitt, 1983, 1992, 1994; Hillyard and Watson, 1996; Leonard, 1997; O'Brien and Penna, 1998; Squires, 1990). What we can discover in Foucault's writing are many allusions, stratagems, discourses and depiction of social practices of power that can elucidate the resistances of 'society against the State'. We will not discover a social 'blueprint' so much as indications of what it might mean to live without those normatively generated theories about the nation-state that he thought so 'indigestible' (1988a; 1991d). His analyses of the normalizing power of the state could never lead him back into any simple support for the idea that nation-states embody some intrinsically valuable political accommodations that stand apart from their discursive formation. All was grist for his mill in this respect. It is precisely this longing for explanations that imprint themselves with some version of teleological intent that he deconstructs. 
The great benefit of Foucault's analysis is to relate the meaning of any current set of political assumptions to how they are constructed and 'known'. Similarly, we can apply this analysis to social policy. As Hewitt has suggested:

The subjects of social policy, e.g. dependency and social needs, are not caused merely by social forces and do not exist as pure facts. They are constructed within the discourse of social policy as categories, classification systems and forms of knowledge by individuals and groups within the political, administrative and economic spheres. (1983: 67-68)

It was the processes of categorization and measurement that established social policy as the 'social arena' within which the issues of social problems were to be debated. Hewitt goes on to argue that social policy 'in particular becomes one of the apparatuses of the state for harnessing and circulating power' (1983: 68). Similarly, Dean argues that:

... in displacing attention from both the constitutional state and the analysis of ideology, the analytic of government reveal the complex and irreducible domain of practices that form the conditions of social policy. Such an analysis thus directs our attention to the need for the analysis and description of the practical rationalities and minor 'arts of government' that are the conditions of existence of a social security system. (1995a: 571572)

An important question is the degree of reflexivity built into this process. While the facts of need were attested and obvious, it is also the mechanisms for responding to them that created the separate arena of 'welfare'. This is an arena which by its very difference and distinctiveness became the mechanism of governance, one which would increasingly measure, sort and differentiate the 'problematic'. What is being constructed under the guise of arguing the need for accurate information are the patterns of how the welfare recipient is to be moralized into the role of client; what Hacking (1986c) calls 'making up people'. This reflects all the manifold ways in which the state will intersect with welfare recipients to demand obedience to an agreed lesser status. For Foucault this internalization of a moral demand arose out of the subordinate role required of those undergoing any aspect of the 'professional gaze'.

Foucault's radical reflections are still vital to us as we seek to understand what it means to participate freely in the world we continually recreate as well as inherit. These debates are never finished and whether it is possible even to bridge the theoretical 'divide' is problematic. How the hegemony of neo-liberalism might be weakened, or how its 'anxiety' to control the threat of excessive welfare dependency (c.f., Osborne, 1994) might be demonstrated, has led me to focus that 'hope' on a rethinking of Foucault. 
Nonetheless, any investigation into his relevance for social policy must respect his unwillingness to develop any new overarching paradigm of the social. Applying his ideas to an investigation of social policy must first acknowledge that such searches were not ones that he, himself, tried to accomplish or those with which he would have had much patience. After all, for Foucault, such normative 'reasonings' were simply another spin of the wheel of power and could not provide any 'surrogate for whatever it is that springs eternal in the human breast' (Hacking, 1981: 37 ).

\section{Conclusion}

Foucault is one of those writers whose ideas seem to leap freshly off the page despite the investigations and interpretations of others. Where he is located (in the process of our social reflections on the on-going debates about welfare access, obligation, dependency and purpose) will continue to trouble contemporary opinion. However, he cannot be easily dismissed, his oeuvre is substantial, there is great seriousness in his work and, at times, it reflects the pained jousting of a man who was continually restless with 'the difficulties and absurdities of all men'. As he wrote, death's 'annihilation is no longer anything because it was already everything, because life itself was only futility, vain words, a squabble of cap and bells' (1965: 16). He does provide us with an opportunity to think again about those things on which we rely most fundamentally in our own internal discourses of meaning in the face of death. There is always that anxiety he would contend and what is in question is still the nothingness of existence, but this nothingness is no longer considered an external, final term, both threat and conclusion; it is experienced from within as the continuous and constant form of existence (1965: 16).

We do not often, within social policy, stay very close to that personal pervasive anxiety but Foucault's intellectual journey does offer an important way to re-connect the structures and plans of differing social analyses within the very sharp observations of that lived anxiety. Setting out a new way to examine these 'limit-experiences' is his most salient legacy. We shall see how woven right through all of his complex investigations runs the thread of his comment that 'things that are made can be unmade'. He set out to describe the 'shape' of our existence, to have us look again or differently at all the intellectuals' 'props' and 'masks' that are so susceptible to the 'squabbling of cap and bells'. It is important that we not lose sight of the fact that he never quite found an 
answer to that which drove him. He remained, as he said, 'more or less imprisoned or wrapped up in this tangle of problems' (1991d: 71).

Considering how Foucault has been 'explained' and appropriated provides some insight about his significance for social policy. We do need a new genealogy of welfare, risk and social policy if we are to revivify debates about the social. Recent political debates, for example, about the 'Third Way' still require more consideration and theoretical reflection before we can assume that it represents a major new political synthesis (c.f., Giddens, 1998). It is by no means clear that we have theoretically moved past the old dichotomies represented by the clash between the 'one and the many'. Foucault did provide an analysis of complex systems of knowledge, and the sophisticated structures of power that have made us what we are, but would not provide any basis for the normative use of his investigations.

How and why we quote him then becomes a separate intellectual journey into the patterns and limits of our own reflection - it is a process with which, it seems, he was well aware (1987b, 1988b, 1993, 1997c). No matter how we 'read' him we are forced to go on dealing with the subjectivity of our own interpretation, it never seems quite to have come to rest (c.f., Deleuze, 1988). Considering the rationales of Foucault's radical questioning of reason, power, history and meaning sets out the logic of Korsten's assertion 'that in terms of theory we find ourselves after Foucault. In terms of practice we may wonder if Foucault is not a spectre in front of us' (1998: 64). What that 'spectre' of Foucault might be, what his relevance to social policy theory might entail and how useful his analyses can be are the issues this thesis addresses in setting out the terms of a revamped social critique. 


\title{
Chapter Two
}

\section{Foucault Revisited: Foucault's 'Place' in the Modernist/Postmodernist Debate}

\begin{abstract}
The postmodern is not a moment (neither, contra Habermas, future utopian nor retronostalgic) beyond the modern. Instead, what is represented by the postmodern is the unmasterable, disappointed condition of the Enlightenment ideal of modernity "after Auschwitz". That is, the postmodern is the modern in the wake of the impossible conflagration - disintegration - of the ideal of progress. The rational image of the modern, of the ideal of progress, is the representational essence of the scientific project of the West. This logical essence has suffered an irrefragable eclipse, and the postmodern simply names the persistence of its occlusion. (Babich, 1992: 98-99)
\end{abstract}

Whether it is indeed possible to consider Foucault a social or political theorist is for many of his commentators not even an open question. Nonetheless, his view of politics as the 'freeing of difference' does establish his relevance to contemporary political reflection about modernity and postmodernity (c.f., Penna and O'Brien, 1996). For, as he indicated, 'freeing of difference requires thought without contradiction, without dialectics, without negation; thought that accepts divergence' (1977c: 185). My purpose in yet one more excursion into this area is not to resolve the question of the place of Foucault per se within postmodernist thought. That is more properly resolved (if it ever can be) within the sociology of ideas and philosophy itself (c.f., Freundlieb, 1988; Harpham, 1994; Rorty, 1990, 1991). Rather it is to examine the contemporary usage of his ideas within these and other disciplines in order to consider whether we can still argue for political and social visions of mutual obligation, recognition of need and support, previously so intrinsic to social policy theory and which are characteristic of modernity. His intellectual journey still contains allusions, hints, stratagems and analytical practices that relate to the odd mix of certainty and risk that is our present politics.

Any attempt to evaluate his thought in relation to the sociology of ideas, the viability of social theory, and an analysis of social policy must negotiate some aspects of the modernist/postmodernist debate. Postmodernism may be 'primarily concerned with the discontinuities of discourse and how any discursive economy simultaneously silences and gives voice to ideas, interests, and identities' (Schram, 1995: 377). However, because Foucault's rhetorical style lends credence to the functioning of such ideas it does not necessarily mean that we can 'place' him as a postmodernist, for he certainly made no such assumption about his work. On one of the specific occasions (in an 
interview with Gerrard Raulet, 1983) when he discussed the idea of postmodernism he declared himself puzzled by the use of the term 'modernity' let alone postmodernity!

Considering Foucault's 'place' within the ongoing sociological debates about modernism or postmodernism provides a different standpoint from which to evaluate his overall significance for social policy theory. For example, his critical perspective about the function of reason in modernity is a search for ways to demonstrate the 'historically instantiated' nature of reason 'which criticizes, not reason tout court, but the relationship between reason, power, and subjectivity' (1993: 119). This approach reflects a pattern of social critique that 'uses the knowledge of limits to establish political options without prescribing resolutions' (Dean, 1994a: 54, my italics). It can be applied to social policy's concerns to implode the logic of typical welfare rationalizations and to ask what it might mean for us to 'start again' and examine the actual practices of welfare politics as specific examples of the various rationalizations that shape modernity. His concept of 'limit experience' - the ways in which Western societies construct experiences that form particular patterns of subjectification - sets out the grounds for his analysis of how we might recognize the limits of the ideal of progress that lay at the core of modernity's self absorption. Elaborating on this dispute about Foucault's 'place', and aligning it with the more specific focus of my concern with theory building within social policy, provides some new reflections on 'our present' and how this critical appraisal might accord with his depiction of 'limit-experience'.

Applying such a critical stance to an analysis of the subjectifications of social policy theorizing seems imminently 'rational' and 'reasonable' for it invites an examination of process and the ineluctability of change and vitiates any reliance on fixed discursive positions. As Richters has argued:

Foucault's thinking or 'theory' does not have a justificatory role, but an analytic one. The thrust of Foucault's work is not to subvert one notion of rationality, as capitalist, instrumental and technical, with another, 'higher' notion, which is socialist, intrinsically emancipatory and enlightening. Rather he undertakes to analyse rationalities, and in particular how relations of power are rationalized. (1988: 620)

It was this willingness to question such ideals while not providing any new answers that has been his most troublesome legacy (c.f., Touey, 1998). The consequent debate about Foucault and his relevance to social theory was threefold. What value can we attribute to these clever and almost 'violent' flights of ideas, where does it lead us and 
what solutions does Foucault proffer? Assessing him in relation to social policy theory might best start with his own question that the "coexistence in political structures of large destructive mechanisms and institutions oriented toward the care of individual life is something puzzling and needs some investigation. It is one of the central antinomies of our political reason' (1988c: 148).

\section{Limits and the 'Heroism' of Modernity}

He stated in his famous paper, What is Enlightenment, that modernity was not an 'epoch' and that it might be better understood as 'an attitude than as a period of history' (1984a: 39). It was this idea that modernity was more accurately perceived as an ethos that he refined into the concept of 'limit-attitude' or 'limit-experience'. It implied limiting the possibility of the present by valorizing certain choices that dictated how the present was to be apprehended and interpreted. He said that some saw modernity as a 'break with tradition, a feeling of novelty, of vertigo in the face of the passing moment' (1984a: 39). However, perhaps of most relevance to his idea about the dominating function of 'limit-experience' is his conclusion that modernity 'is not a phenomenon of sensitivity to the fleeting present' but rather reflects the 'will to "heroize" the present' (1984a: 40). Criticizing the 'limits' inherent in this attitude he argued that we are connected to the Enlightenment not through 'faithfulness to doctrinal elements' but in how we establish a 'permanent critique of our historical era' (1984a: 42). It is this oppositional stance to what he sees as false 'heroics', one that constrains our present and limits our possibility, that shaped much of his work.

We cannot simply 'isolate' Foucault as if he was a postmodern iconoclast, espousing an impotent irrationalism. Right throughout his work he did insist 'that his philosophy exemplifies the Enlightenment ethos of self-critique' (Cook, 1993: 119). Nonetheless, even though he vigorously rejected such a role, setting out the structure of the 'dark side' that could not be dismissed within the reasoned ideals of a modernist perspective has earned him a certain prophetic aura. Cook summarized this misappropriation well when she concluded that 'Foucault and Derrida are to a certain extent the prophets of a postmodern age without themselves being post-modern' (1990: 40).

Posed simply in relation to social policy theory, the questions that postmodernism highlights are not just the issue of specific differences between conflicting policies but 
whether the parameters of social policy itself are still possible? Other related questions are the following.

- Can we ever again seek to explain our politics, our social relations and our theories of the person, in any expansive or overarching way?

- What are we to make of Foucault's assertion that we require 'affirmative thought ... that is not limited or confined by the constraints of similarity' (1977c: 185)?

- What might it mean for our social theorizing if we do, as Foucault asks, 'think problematically rather than question and answer dialectically' (1977c: 186)?

Foucault's dilemma is also ours. In prose that often polarizes, he sets out the possible ground for the 'transgression' of the specific definitions and representations that determine who we are and how we should behave. For example, what personal and political choices are available in a world that is 'governed thus' (c.f., Pavlich, 1995)? What are the processes by which we are made subjects and 'how has the individual become a problem for knowledge in Western culture' (Cousins and Hussain, 1986: 175)? This is an examination, in his terms, of 'limit-experiences' and represents his ethical demand that we consider openly the constraints built into our perception of the normalizing present.

\section{Finding Foucault?}

A secondary aim in revisiting this debate about the 'place' and thus the significance of Foucault is to set a discursive context that demonstrates how it is that there are so many and varying 'Foucaults' all jostling for their interpretive truth. The plethora of these raises some interesting questions. Does our inability easily to 'place' him reveal something of the epistemological confusion that riddles our politics and which also renders debate about social policy provision in rhetoric that is stylised and ideologically entrenched? Can we redraft a 'common' definition and recognition of need that is not eviscerated by a postmodern focus in social policy (c.f., Goodin, 1985, 1988; Hewitt, 1996; Leonard, 1997)? Alternatively, can we apply Foucault's ideas to an examination of social policy within a postmodern framework that does allow for a fuller examination of how do we govern ourselves (c.f., Leonard, 1997)? The question really is whether there can be any convergence between the multitude of social movements (in themselves representative of postmodern 'difference'), with their explicit or particular sense of needs, and how political policy-makers respond to this 'clamour' of needs and rights talk?

Whether we can fashion any effective political rhetoric that reflects the old metaphors of social obligation within prevailing contemporary discourses of individual risk is doubtful. 
Nikolas Rose's initial work on the presumed 'death of the social', and how we are governed through independent communities of self-interest, would suggest not (c.f., 1996a, 1996b) - although he subsequently wrote that it was not so much a 'death' but how 'the social space of welfare [was fragmented] into a multitude of diverse pockets' (Rose, 1999: 160).

The individualization of risk does not accurately represent the 'death of the social' but rather the 'transformations of the liberal and social problematic of security' (Dean, 1999a: 197). We can, therefore, use Foucault to examine the rationalizations and subjectifications that govern our present politics and critique neo-liberal welfare policies. Brenner, for example, offers an interesting view that comparative work on the relationship of Foucault's notion of 'bio-power' to variations in welfare state capitalism is only now enjoined. He refers to some work done in Germany by Joachim Hirsch on the German welfare system where Foucault's analysis of power can be more properly associated with a 'Fordist' modernism. He suggests that much is still to be done to unravel Foucault's relevance in a 'post-Fordist', postmodern context (1994: 701 and note 47 p. 708). How we resolve this question determines how well his ideas can be used to develop a critical theory of modernity within which most of the idioms and rationalizations (the 'ethos' of welfare) are grounded.

My purpose in returning to this well-canvassed debate about Foucault's 'place' in modern thought is not to attempt to resolve the impasse that it represents in critical theory, or even to focus solely on his contribution to this debate, but to set the arguments within a social policy theory-building context. For my inquiry it is the patterning of that debate that is most useful provokes the following questions.

- What aspects of this contentious reflection about Foucault can we ascribe to the task of understanding how we make social theory and determine policies?

- What does the debate about Foucault demonstrate about how we justify certain policies and winnow others?

- What are the rationalizations for action (Habermas' 'juridification' process - the complex legalizing of social life) that might be clarified if we apply Foucault's analysis to reveal the practice rather than the rhetoric of policies?

- What impact on social policy can be drawn from Foucault's governmentality thesis?

- What will it mean if Drucker's interpretations are correct that the present is an era when our social relationships are based more upon contract and performance than authority (1969)?

- Has Foucault destroyed the basis for trust in Enlightenment Reason, and by implication any justification for universal or comprehensive social policies? 
Canvassing some aspects of these questions provides an opportunity to assess the status and purpose of general social theories. Because Foucault 'dialectically evades simple reversals' (O'Hara, 1992: 76) the nature of his investigations will not allow for an analysis of welfare to be grounded in descriptive metaphors that involve simple binary opposites. Welfare and social policy cannot be adequately explained simply by distinguishing between independence and dependence, or laziness and industriousness, to list just two possible pejorative pairings. He did not seek some new and persuasive 'articulation of the views of a subordinate class, or a judgement of the competing claims to validity of different modes of programming behaviour' (Smart, 1986: 171). Nor would he give support to the assumption that welfare systems were some essential bourgeois ruse, or equally that welfare recipients per se were innocent victims of power.

What he sought was a new way to examine how we govern ourselves. That led him to re-conceptualize the relationship between reason, power and subjectivity. His thesis of 'bio-power' (set out in The History of Sexuality, Vol. 1, 1990) provides analytical tools that we can use to challenge the inevitable discontinuities of various welfare and social policy discourses that represent particular forms of subjectification. He challenged 'what is' but refused to offer any replacement paradigm. To accede to that would have 'frozen' his ideas within the very tradition of epistemological inquiry he criticized. He never claimed to have 'escaped the effects of power or assumed that the critical detachment of authorship would give him any special claim on its "truth"' (Aladjem, 1996: 284). His own view, influenced by Nietzsche, was that the 'forces operating in history are not controlled by destiny or regulative mechanisms, but respond to haphazard conflicts' (1984c: 88). This allows for a quite different set of reflections - his thesis of 'limit-experience', for example - on the meaning and articulation of social policies and how they depict aspects of the social processes of subjectification and normalization.

Foucault's refusal of a separate moral or ethical dimension to welfare practice and policy does not mean that we cannot apply his ideas to an analysis of 'the complex constitution of social hegemony' reflected in our welfare systems (Smart, 1986: 171). Towards the end of his life, he did, in the three volumes of the History of Sexuality', shift his focus towards a 'technology of the self'; one that 'would allow him to attribute historical events to moral agents - that is, to give power back to subjects' (Cook, 1993: 130). As Scott suggests, Foucault's refusal to articulate any 'inherent meanings does not plunge us into 
an abyss; rather, it makes the production of meaning a human, albeit historically variable and contested, activity' - the core aspect of his idea of 'limit-experience'. She continues that in the absence of 'inherent landmarks or points of reference' we humans have still tried to establish them. "Indeed the "lesson of history" is that human agency consists in imposing sense, differently and mutably, upon our worlds' (1996: 20). It was this that made it possible to argue that Foucault 'was progressively working towards the theoretical grounding of the struggles of the disempowered' (Cook, 1993: 144). This reflected, as Hacking argued, an ethical orientation influenced by the bleaker aspects of 'post-Auschwitz' reflection (1990: 10).

\section{The Dark Side of Modernity}

Foucault was deeply affected by the 'disappointed condition of the Enlightenment ideal of modernity "after Auschwitz"', and the nature of his critique - particularly in Discipline and Punish, arguably with The History of Sexuality Volume One the most famous of his books - does represent the 'dark side of modernity' (c.f., Garland, 1997; Habermas, 1986a, 1986b; Hacking, 1990; Lash, 1985; Nehamas, 1993). It is this aspect of his thought that sets up his appropriation by some current writers as a postmodernist. It lends substance to the view that Foucault was caught up in the 'wilder' labyrinths of 'post Auschwitz' modernist reflection (c.f., Nehamas, 1993; Ray, 1988: 101-2). Because his rhetorical style, as well as the content of his ideas, reflects aspects of the denied or occluded 'appealing' to his thought as a postmodernist is understandable. Nonetheless, it is a misguided application of his ideas for Foucault is more properly termed a modernist than a post-modern theorist (c.f., Flynn, 1991; Hoy, 1991; Johnson, 1997; Rajchman, 1983a).

While he could write poetically and imaginatively, often demonstrating an allusive and compelling rhetoric, he refused to be anyone else's ally or guide. To frame his questions, as he often did, in such prose as the following - will we reflect on 'the morning of being or [be imprisoned within] the noon of representation' (Flynn, 1989: 197) suggest images that are anathema to the typical linguistic metaphors of much social science. So much so, that this aspect itself, is often used to sidetrack debate from the significance of his ideas. 
Stylistically and idiomatically he does not 'fit' within the idioms of sociological and historical analysis and he can, therefore, be wrongly rejected as an irrelevant 'social' theorist. But his prose, while sometimes couched in such poetic language, was not designed deliberately to create yet more obfuscation. Rather it reflected what Aladjem calls a 'profound humility before the complex enclosures of the historical past and the variety of human existence' (1996: 284). For many, as we shall see, any conclusion that Foucault could be humble is risible but Deleuze argues that such sentiments are intrinsic to the 'passion' that drove Foucault (1995: $98 \mathrm{ff}$.).

Entering into Foucault's 'thought-world', in whatever way possible, is to glimpse the dilemma of political change at its most paradoxical (c.f., Deleuze, 1995). Given the nature of his rhetorical style (and his translators) it is easy to take extracts of Foucault's ideas and fashion a pejorative exegesis. He refused simply to take the side of the subordinate or the oppressed for that 'would be to indulge power from another direction, to attempt to raise what power has stunted as a principle of opposition to power' (Aladjem, 1996: 285). He framed his critique differently in order to challenge the overweening nature of the processes of normalization and subjectification. This 'refusal' to echo the great normative 'rhetorics' of radical change and possibility set him on a particular path which can seem nihilistic and uncompromisingly indifferent to any expectation of progressive social change. One possible reason for this was his disgust at the brutal excesses of the Second World War and how this affected his centrally modernist consciousness (c.f., Foucault, 1980b). Whether he was 'successful' or not his intellectual journey does echo something of our beleaguered present.

\section{Auschwitz and the 'Progress' of Reason}

The depiction of postmodernism in the prefacing quote described it is a 'disappointed condition', reflecting modernism's inability to counter the disintegration 'of the ideal of progress', consequent upon the horrors of two World Wars and particularly Auschwitz (c.f., Fackenheim, 1985). It is a sentiment similarly echoed in the later Foucault (c.f., Cook, 1990; Bernauer, 1988; Milchman and Rosenberg, 1996). Miller, one of Foucault's major but contentious biographers (see also Deleuze, 1988; Eribon, 1991; Macey, 1993), stated that all through his life Foucault 'was haunted by the memory of Hitler's total war and the nazi death camps' (1993a: 171). 
Hacking commented on this bleaker aspect of Foucault's thought and suggested that:

... parallel to the taming of chance ... [modernism's great goal] there arose a self conscious conception of pure irregularity, of something wilder than the kinds of chance that had been excluded by the Age of Reason. It harked back in part to something ancient or vestigial. It also looked into the future, to new, and often darker visions of the person. (1990: 10)

Bernauer also recounts his personal reaction to a photo of Foucault visiting yet 'another prison', only to recognize that it was indeed the infamous Auschwitz prison (1988: 260). In one of his later articles Foucault argued that the Second World War demonstrated an unprecedented 'butchery' and, interestingly in relation to the typical themes of social policy, went on to say that:

$\ldots$ it is precisely this period, this moment, [of 'butchery'] when the great welfare, public health, and medical assistance programs were instigated ... One could symbolize such a coincidence by a slogan: Go get slaughtered and we promise you a long and pleasant life. Life insurance is connected with a death command. (1988c: 147)

However his overall intellectual place is assessed, his ability to 'upset' considered reflection is nowhere better demonstrated than in the above quote. He did ask thorny questions about Enlightenment ideals of reason and progress (c.f., 1984a, 1986), an observation often taken up by those who argued for Foucault's 'place' as an exemplary postmodernist (c.f., Leonard, 1997). His great rhetorical skill was to pose new and awkward juxtapositions of ideas that led to the 'opening up' of accepted complacencies the notion of 'seeing things differently' that Deleuze (1988: 32, see also $50 \mathrm{ff}$.) captured so well. This was the rationale behind his theory of 'limit experience' and how various rationalizations shaped the processes of subjectification.

While he vigorously 'resisted' the idea that he could be 'explained' or easily 'located' (c.f., 1977a, 1977b, 1988d, 1991d) some aspects of his preoccupation with discipline, power, punishment and the creation of 'docile bodies' echoes as the tribulations of a post war intellectual. Foucault has thus often been associated with the 'wilder' aspects of postmodernism and ushering in such 'darker visions of the person'. Lash, for example, argues that his preoccupation with the 'Other' demonstrates that 'the realm of darkness', excluded from Enlightenment discourse, 'are the figures of madness, sexuality, desire and death' (1985: 4).

There is much in his writings that can lead to this interpretation. He was fascinated with the irrational and because of this his efforts to rethink knowledge, power and reason can 
be rejected as illogical. It is, however, too easy to argue that he embraced an antireason or some new ethic of the self, based upon a theory of desire or the released irrationality that lurks underneath reason. His work did embrace meanings that depend upon re-opening the discursive realms of the 'Other', but what we are invited to examine is the interaction between what we mean by reason, not that reason per se has no point (Cook, 1993: 119). For example, as Foucault argued in a discussion about postmodernity:

... if it is extremely dangerous to say that reason is the enemy that should be eliminated, it is just as dangerous to say that that any critical reasoning of this rationality risks sending us into irrationality ... This is the situation we are in and that we must combat. If intellectuals in general are to have a function, if critical thought itself has a function, and even more specifically, if philosophy has a function within critical thought, it is precisely to accept this sort of spiral, this sort of revolving door of rationality that refers us to its necessity, to its indispensability, and at the same time, to its intrinsic dangers. (1984g: 249)

These are not the sentiments of someone totally committed to the place of irrationality as the sole driving motif! They are about examining the discursive meanings of what we rationally hold dear and opening them to scrutiny. Often it is his idiosyncratic and apparently random juxtaposition of ideas that is important. 'Go get slaughtered and we promise you a long and pleasant life', for example, is the kind of epithet that reflects an expression of that 'disappointed condition' which Babich (1992) identifies in the preface.

\section{Postmodern 'Anxiety': Pessimisms and Irrationality}

Whatever the interpretative substance of the prefacing quote it does express one kind of 'voice' that exemplifies something of the wounded or anxious 'spirit', implicit in some current debates about the status and nature of postmodernism. There is an apparent regret, embedded in the relentless assumption in much of this discourse, that there has been an eclipse (betrayal?) of the ideal of progress and that the metaphors of dispassionate reason are no longer fruitful. Johnson defines such postmodern political thought as 'corrosively skeptical' (1997: 559). It exemplifies a kind of lost innocence and expresses a dispirited mood, often articulated in the form of intellectual victimized complaint about that loss. Cook describes this mind-set as 'cautionary despair' and 'ambivalent pessimism' (1993: 109). It is a kind of quasi-grumbling at the 'failure' of those ideas that were presumed to be immutable (the magisterial rationality of the Enlightenment 'project'). Antonio, for example, constructs an imaginative list of what such postmodern philosophical conjecture covers, namely: 'pastiche, radical pluralism, eroded standards, disjunction, decenteredness, uncertainty, indeterminacy, immediacy, 
nostalgia, ahistoricism, floating signifiers, blurred sociocultural borders, and restructuring of post-World War Two organizational and political economic arrangements' (1998: 4041).

Foucault, as we shall see, is often 'placed' within this postmodern intellectual stream and scorned as a major exemplar of the presumed 'irrationalism' implied in such stances (c.f., Antonio, 1998; Fraser, 1989b, 1997; Freundlieb, 1988). These assumptions about where to locate Foucault are reflexively revealing for he is not easily 'placed' as a postmodernist. Simply to equate postmodernism with 'irrationality', and see Foucault as its high-priest, is to miss the point that these sets of ideas are also aligned with an analysis of 'how discursive practices produce 'remainders' or what is inevitably left out' (Schram, 1995: 377).

The notion of remainders not only includes various groupings of people in their particular subjectifications but also indicates those sets of ideas that are determined to be unacceptable and 'dangerous' (c.f., Deleuze, 1995; Katznelson, 1986). Valverde, discussing Derrida's recent book Politics of Friendship, suggests that his question about the nature of justice was not what is justice but more significantly 'how can we, in our particular time and place, work in the direction of justice' (1999: 302, my italics). Similarly, Foucault in his discussion of discursive practices was not interested in reason as such but how we understand differing practices of reason. His research style and methodology provided new ways to examine the 'constrictions' of these discursive practices.

Tully, discussing Foucault's 'debt' to Arendt, suggests that both theorists thought freedom resulted from the renouncing (or agonistic contention with) whatever it was that undue sovereignty required (1999a: 162, c. f., Johnson, 1997). As he continues, 'the prevailing modern theories of politics (modern 'humanism') ... universalize a certain state of play and so obscure rather than illuminate how we constitute and are constituted by the games and practices in which we think and act' (1999a: 166). There are important conjunctions between the rigidity of neo-liberal welfare policy prescriptions and postmodernism. To reveal that 'certain state of play', and to 'think and act differently', was Foucault's driving purpose (1985: 8; c.f., Hewitt, 1994). It required an analysis of 
the limits that must be transgressed (his notion of 'limit-experience') if any effective challenge to these rationalizations were to be mounted.

Part of that quest will be to reflect, along with Babich, that the preoccupation with postmodernism is 'not merely the elliptical fancy of a new rage'. As she argues, 'it will not do to convert the "post" of the postmodern into an anti-or amodernity. The implication of transit, of a passage through modernity is essential' (1992: 106). As we examine the restrictions now placed on social policy theory by defensive attitudes about the legitimization of need and the plethora of social claim rights it will be necessary to demonstrate the connection between postmodern anxiety and the lack of any real political will to proffer solutions. Carter, for example, discussing the status of contemporary social policy theory, wonders whether a 'postmodern welfare template has [now] been forged for the new age of anxiety' (1998: 2, my italics).

Foucault and his polarized 'interpreters', as I will argue, offer some guide to the apparent contradiction that the attack on normative prescription, exemplified in postmodern theorizing far from being simply irrational has an ethical dimension. It illuminates the impotent fallacy of the neo-liberal assertion that 'there are no alternatives'. Babich's notion that postmodernism is part of a journey or transit is significant. Particularly if we are to argue that neo-liberal market solutions, presumed in the cachet of 'there is no alternative', while a normative rupture in welfare and social policy theory, nonetheless, still represent themes about a constantly changing political 'journey'.

Curiously the notion of magisterial certainty in neo-liberal policy prescriptions echoes the specific mind-set of the social democratic welfarism it sought to criticize. At the very least we might argue that postmodern welfare theory presents the conundrum that some new reflection is needed (c.f., Bauman, 1997; Hewitt, 1994, 1996; Leonard, 1994, 1997; O'Brien and Penna, 1998b). Whatever 'shape' our future welfare politics might take it will be post-Foucaultian in the critical effect of his governmentality thesis (1979b). How we assess welfare policy as a 'practice', as well as debate the validity of social theory, how we recognize and 'free our differences', are questions for which Foucault provides, if not answers, nonetheless a way to critique taken-for-granted assumptions of neo-liberal social theory. 


\section{Locating Foucault: 'Rebel' but in what cause'?}

Questions about Foucault's 'place' in contemporary intellectual debates - for example, is he a modernist or a postmodernist, is he a philosopher or a historian and how he is to be explained - have generated a great deal of polarized critical reflection (c.f., Allen, 1998; Hekman, 1996; McGowen, 1994; Noiriel, 1994; Rorty, 1990, Touey, 1998). What brought him to prominence, and stimulated these contentious debates about his significance and intellectual 'identity', is that he seemed to have provided new ways to reflect on the patterning rather than the polemics of rhetorical and historical change. Deleuze, for example, argued that Foucault's approach to historical analysis was determined by his thesis of 'limit-experience' and suggested that:

History, according to Foucault, circumscribes us and sets limits, it doesn't determine what we are, but what we're in the process of differing from; it doesn't fix our identity, but disperses it into essential otherness ... Actuality is what interests Foucault, though that is what Nietzsche called the inactual or untimely; it's what is in actu, philosophy as the act of thinking. (1995: 95)

The specific nature of his inquiry undermined the legitimacy of typical patterns of historical reflection that relied on the stance of the clever, reasoning, but necessarily dispassionate observer. He argued that we could no longer rely on the possibility of a valid 'general history' that pursued what he called the 'privileged shelter for the sovereignty of consciousness' (1972: 12; c.f., Goldstein, 1984, 1994, 1998; Korsten, 1998; Scott, 1996). This stance eventually led him further to question the logic of Enlightenment reason that was deliberately uncritical of the historical bases of that 'sovereign consciousness'. This was one reason for the scorn he received and for his being vilified as an irrational postmodernist (c.f., Foucault, 1984c; Freundlieb, 1988; Castel, 1994; Megill, 1979, 1987; Taylor, 1986; Veyne, 1997). He invited controversy even if he sometimes seemed to affect a perplexity about it all (1991d: 169). To all the jousts that he was a postmodernist, with no effective methodology to distinguish totalitarian regimes from democratic ones, his insouciant riposte was that just proved how 'contemporary' were his ideas!

It is a truism that Foucault has continued to 'trouble', as well as inform, excite and support, scholars in a wide range of intellectual arenas, including criminology, philosophy, historical analysis and methodology, literary criticism, gay studies, feminist analysis and, increasingly, sociology and social policy. In some disciplines, such as criminological theory, and in semiotics, his ideas have already redrafted the nature of 
theoretical argument (c.f., Cohen, 1985; Garland, 1990, 1997; Holub, 1985; Pratt, 1985; O'Hara, 1992). Pratt suggested that it was 'hard to overestimate the impact that Michel Foucault's Discipline and Punish had on criminological thought ... and the ferocity, vitality and volubility of the debates that it inspired' (1992: 7). Cohen also suggested that criminology had finally found in Foucault's ideas on discipline 'a vocabulary with which to comprehend more recent changes' in penal theory and practice (1985: 8). He describes this contribution as so vital to criminology that 'to write today about punishment and classification without Foucault, is like talking about the unconscious without Freud' (1985: 10). Garland, in similar vein, suggested that:

The work of Michel Foucault, and particularly his book Discipline and Punish has recently become a central reference-point in the sociology of punishment. In fact Foucault's influence has been such as virtually to eclipse the other, more established traditions ... and to set a new agenda for contemporary research in this field. (1990: 131)

$\mathrm{He}$ is yet to have the same impact in social policy possibly because there is no obviously similar critical text for social policy as that place held by Discipline and Punish in criminology. However, Foucault's own statement about the function of criticism provides a perspective from which to analyse the taken-for-granted 'truths' of neo-liberal social policy. As he stated:

... criticism is no longer going to be practised in the search for formal structures with universal value, but rather as a historical investigation into the events that have led us to constitute ourselves and to recognise ourselves as subjects of what we are doing, thinking, saying. (1984a: 45-6)

Whatever Foucault meant by his theory of 'bio-politics' (1981a; c.f., Hewitt, 1983; Rose, 1999 ) it was not to contribute to that fractious debate within the left of an appropriate or effective 'theory of the state'. In fact, Gordon suggested that he 'was inclined to make fun of what he called a tendency, shared by the Left, towards "State phobia"' (1996: 263). He argued that much of the criticism of Foucault, that he proffered no adequate theory of agency, came not from 'his insufficient aversion to the State, as in his unwillingness to take the side of society against the State' (1986: 263). He suggested that he was not contemptuous of the social bond but rather that he mistrusted it. As Foucault argued:

The coexistence in political structures of large destructive mechanisms and institutions oriented toward the care of individual life is something puzzling and needs some investigation. It is one of the central antinomies of our political reason ... when we ask for support as unemployed, even when we vote for or against a government which cuts social security expenses and increases defence spending, even in these cases, we are thinking beings, and we do these things not only on the ground of universal rules of behaviour but also on the specific ground of a historical rationality. (1988c: 147-148) 
Discussing the polarized opinions about Foucault as a discrete inquiry affords a separate insight into the nature, or more particularly the practice of social debate - thus providing a new perspective on the social policy and welfarist discourses that are an intrinsic aspect of our Western cultural history. I agree with O'Brien's observation that the 'body of Foucault's writing has seldom been recognized for what it is: an alternative model for writing the history of culture' (1989: 25; c.f., Poster, 1997). If it is a cultural 'model' for the 'freeing of difference' (c.f., Hekman, 1996) then we may usefully apply his ideas to critique the rigidities of neo-liberal social theory and practice. The question, framed more generally, is does Foucault's cultural 'history-making' introduce a new reflective critique (analysis of patterning and practices rather than advocating some new polemics) capable of generating new insights into the ideology of welfare and the making of social policy?

\section{Normative Theory: What Possibility?}

Simply put, the issue facing critical theory is how to gain leverage within a milieu of obvious common sense individualism. Philosophical legitimization of the social, 'what [does] it mean to create some legitimate commonality ... with "legitimate" here carrying the sense of reciprocity and mutual respect' (White, 1988a: 154), is vital for critical reflection. Foucault's genealogical project challenges critical theory to elaborate explicit discourses that give 'expression to those voices that have been marginalized by specific power-knowledge arrangements', more specifically to 'revitalise lost discursive events' and facilitate the 'insurrection of subjugated knowledges' (Pavlich, 1995: 556). Foucault's assumption that there is no 'neutral rationality' and that 'social practices condition cognitive discourse' (c.f., Nielsen, 1997) does not demolish the possibility that 'subjugated knowledges' can be used to challenge current hegemonies. Indeed he argued that it was through the re-emergence of 'disqualified knowledges' (Schram's 'remainders' 1995: 377) that 'criticism performs its work' (1980a: 82).

Being critical, Foucault argued, reflects an attitude, a process, and never a project to be completed. He would have rejected this possibility of a non-coercive world and seen all calls for such 'freedoms' as false 'siren calls'. He did not seek for some new or radical emancipatory ideology. He refused to see social shifts and patterns as 'ruses' of some dominating particular power. He argues against the Marxists that bourgeois support for welfare was not a stratagem that masked a deliberate private concern for individual 
welfare. As Cousins and Hussain conclude, Foucault did not consider any one particular aspect of the modern state, in this instance welfare policy and practice, to be 'outside of power, or lacking in power'. They suggest that welfare systems are 'not founded in compassion or noble sentiments; it is a 'thing of this world' embedded in constraints bearing on individuals (1986: 178). It is this the practices of these specific constraints that require reflection, not the simple clash of ideologies and the fight to establish some new normative superiority. It is rather to see how 'welfare' is embedded in the normalizations of power.

What seems obvious, nevertheless, about Foucault's oeuvre is that he did see 'the struggle for interpretative dominance as a defining feature of the genealogical method' (O'Malley et al., 1997: 506). While he might explicitly reject any emancipatory ethic that seeks normative closure, his work, nonetheless, sought to 'ground' our social hurts within a 'discursive realm free of coercion or manipulation'. Specific constrictions of the public sphere can be challenged, applying his genealogical critique. In the light of this understanding of Foucault, Nielsen has passionately argued:

All analysis and criticism must work from within some distinctive cluster of social practices, and, if as genealogists we are to do critical history, we should recognise and acknowledge right at the start our polemical interests motivating our investigation and critique of the emergence of contemporary social power. We should not seek to disguise from ourselves that we are political animals in the midst of political struggle. Our intent as political animals is to rectify the malignancies in our social practices. To do that effectively we must understand them in a genealogical manner. (1997: 13)

Nielsen's valuable insight is to see how important it is to set such genealogical searches within a diachronic and not a synchronic perspective. It is part of the power of neoliberalism's incorporation of risk into its anti-welfare rhetoric to depict welfare beneficiaries as part of a synchronic reality.

While it is clear (from within a neo-liberal perspective) that historical overviews can be made about the structural problems of institutional welfare, verification of personal history is not granted to the welfare recipient. ${ }^{x i}$ The implicit 'stone' of such social stigmatism is that the 'welfare - other' will be accorded no 'historical' or precursive reality. To do that would be to ground their experience within some description or understanding of a legitimacy extending over time. The implication of this for critical theory is clear. Revealing 'subjugated knowledges' requires that they be studied and argued diachronically (c.f., Hekman, 1996). Those who fall outside the brave new world 
of the marketplace become 'impotent, indolent players' (c.f., Bauman, 1997). Consequently, they are relegated to some current stigmatized class or grouping by a synchronic constriction of their experience. They are excluded from the market 'game' and thus have no 'right' to their history. ${ }^{\text {xi }}$

Neo-liberalism collapses the individual complexity of welfare discourses into the relative simplicities of risk and scarcity. These reflect various 'mantra-like' discourses: the welfare state, for example, cannot sustain such high levels of expenditure; or people would rather accept welfare than work. Security is no longer related to the social, about the satisfaction of an 'infinite' range of hopes and fears, but is now associated with the protection of privilege. In this respect the notion of 'subjugated knowledges' has its sharpest relevance, and Foucault's genealogies, which explicate these 'knowledges', have their ethical grounding. Any critical reflective task that would reveal these 'subjugated knowledges' must also demonstrate that neo-liberalism has 'continuously excluded 'otherness' in its one-way history of modernism'. It is a political perspective that exemplifies the consequences of an implicit trust in one of modernism's central assumptions that there can be 'no alternatives' to the logic of a fiscal or free-market reality. Reliance on such 'givens' provides the rationale for the structures of welfare politics that Fraser unravels (1989a, 1989b, 1993, 1997).

Successfully revealing that otherness gives some hope that we might yet create 'a postmodernism of resistance to the series of exclusions that that modernism was based on' (Richters, 1988: 630). This concept of otherness is significant in Foucault's oeuvre and has some correspondence to the importance of the 'silences of social policy', discussed previously, where specific welfare discourses exclude completely such

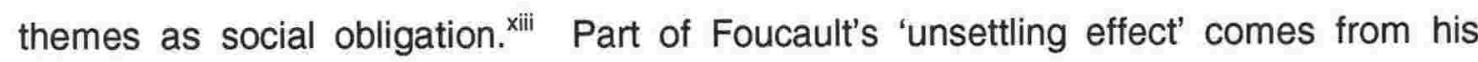
'moral-aesthetic' focus on what 'one might call a sense of responsibility to otherness', which White argues is not only neglected but actively 'shunted aside in modern life' (1988b: 191). What this notion of otherness indicates is the same elusive awareness that preoccupied Katznelson who enjoined us to 'develop a taste for thinking about possible worlds that are not very far away, but seem to be just beyond our grasp' (1986: 325). Such a shift in imagination is discomfiting to a 'logocentric style of thinking' that cannot easily tolerate such intentional voiding of rationality. It certainly is not commonsensical! 
The moral-aesthetic force of such thinking which led Foucault to pose a 'responsibility to otherness' is counter-posed with the obverse, currently dominant in Western political thought, which seeks to develop 'a sense of responsibility to act in the world in a justifiable way' (White, 1988b: 191). He argues that the language of politics must embrace both the practical aspects of co-ordinating action and the 'world opening' otherness of Foucault. Acting responsibly to otherness 'means inevitably ... treating people as alike for the purposes of making consistent and defensible decisions about alternative courses of action' (1988b: 192). It represents a different aspect of common sense that we certainly require if we are to mount any effective challenge to the rejection and stigmatising of welfare recipients.

Foucault's somewhat infamous aim to make an ethics of the self, 'to create ourselves as a work of art' (1984d: 351), makes more sense when seen in this light. xiv As Deleuze argued:

The key thing for Foucault, is that subjectification isn't to do with morality, with any moral code: it's ethical and aesthetic, as opposed to morality, which partakes of knowledge and power ... what is our ethics, how do we produce an artistic existence, what are our processes of subjectification, irreducible to our moral codes? Where and how are new subjectivities being produced? What can we look for in present-day communities? (1995: 114-115)

The potential to recognize fully the diachronic reality of the welfare 'other' is clearly 'there' in Foucault's commitment to the making of personal histories. What is not always so clear is how these histories might be used in the 'realm of contestation and struggle' (McNay, 1992: 190). That is still the key question for critical theory. Post-modernism may sit uncomfortably with acknowledging the 'violence' of such abstractions and has little patience with trying to draft these personal histories into 'meta-narratives' but, as Foucault argued, if 'everything is dangerous, then we always have something to do' (1984d: 343)! It is how we articulate that danger and the means we find to enlarge the arena of this discursive debate that is significant.

\section{'Foucault' and Postmodernity - a Contested Site}

Foucault generated an intensely polarized debate about his significance as a commentator on the 'disappointed condition of the Enlightenment ideal of modernity' as well as his personal style. He can never be tightly woven into any one facet of philosophical, historical or sociological theory. Both in his person as well as in the structure of his arguments he became the 'site of continued contestation, struggle and 
appropriation' (Dean, 1998: 182). This arises, in part, because these analyses are often lodged within explanatory categories, methods and metaphors intrinsic to a particular epistemology that shapes the boundaries of the various disciplines. Foucault's 'problem' for many commentators is that he does not adhere to the discursive rules familiar to the pattern of reasoned debate within which they are required to couch the idioms of their particular critiques. His cleverness that seemed so prescient and 'sharply contoured', as Hacking described (1998b: 85), could melt away in an apparent 'elusiveness' that for many critics rendered his ideas interesting as poetry, but little else (Rorty, 1991: 196).

For example, Giddens' consideration of Foucault is cursory and somewhat dismissive (1991: 57; 1995: $262 \mathrm{ff}$.). Lash and Urry (1994) make the assumption that this hostility occurs because he regards Foucault's ideas as 'a threat to ontological security'. ${ }^{x}$ It is certainly true that they differed markedly about the human subject. Gordon also suggests 'that Foucault's representation of society as a network of omnipresent relations of subjugating power seemed to preclude the possibility of meaningful individual freedom' (1991: 1). The implicit assumption of ontology that the human subject was the 'fount of meaning' and social relationships are one consequence of that prior subjective knowing was anathema to Foucault. He insisted on 'the efficacy and logical priority of social relations in the analysis of knowledge and social practice' (Cousins and Hussain, 1984: 252). Modernity, for him, is an 'attitude' not a valid 'period of history': it is a 'vertigo in the face of the passing moment' (1984a: 39).

Clearly such ideas are an affront to Giddens, who presented a theory of 'structuration' which maintained that humans 'are always and everywhere regarded as knowledgeable agents, although acting within historically specific bounds of the unacknowledged conditions and unintended consequences of their acts' (1995: 265). He presents a view of tacit knowledge which is inherently static and ignores Wittgenstein's assumption that the 'important thing about knowledge ... is that it is always potentially open to challenge' (Pleasants, 1997: 32). Foucault's privileging of social relations in an analysis of knowledge is useful in allowing us to stand back from the dominance of neo-liberal thought. Giddens, however, appears to see the self as heroic and ultimately triumphing in the battle 'against ontological insecurity', so apparently typical of the 'high modern self' (Lash and Urry, 1994: 42). It is a 'warrior' narrative in which the 'fight' is against real, 
rather than imagined hurts. Imaginatively, Giddens battles against 'principalities and powers' while Foucault undermines the legitimacy of the 'battle'!

\section{Has Foucault no 'fight' in him?}

Foucault has often been criticized for providing no real answers to the intellectual problems of the age (c.f., Keenan, 1987; Taylor, 1986; Fraser, 1989b). Smith, somewhat fancifully, suggests that Foucault's philosophical stance was as Lear's fool who could only assist 'the descent into madness' (1991: 53). The 'wild' and various responses to his ideas do stand as a separate commentary on our contemporary worldviews! Habermas' proto-typical argument with Foucault was that his anti-normative stance destroyed any reason to fight for a better society (1986b, 1992). The defenders of Habermas set their 'champion' against the 'interloper'. The major outlines of this have been well discussed already in two significant books Critique and Power: Recasting the Foucault/Habermas Debate (Kelly, 1994) and Foucault Contra Habermas: Recasting the dialogue between Genealogy and Critical Theory (Ashenden and Owen, 1999).

The implication in both of these titles, and in many of the articles written on this topic, is that it was and still is a hotly contested issue. Foucault's response to these charges, that he provides no rationale for any reformist agendas, reveals why he is often mistaken as a postmodernist. This ferment, however, represents a particular gloss on the exchange between Habermas and Foucault (c.f., Bevir, 1999; Campbell, 1998; Dumm, 1988; Fleming, 1996; Flyvbjerg, 1998; Lash, 1985; Nielsen, 1997; Owen, 1996; Tully, 1999b). Nonetheless, as Owen argues, it can hardly be called a debate since both men 'manifestly failed to engage each other' in any kind of open and mutual contested dispute (1996: 119; c.f., Lash, 1985: 11; Richters, 1988: 614).

That this 'conflict' between Foucault and Habermas has been so heralded is more indicative of the relative floundering that has overwhelmed critical theory in the presumed postmodern era. It indicates the difficulty in generating a 'post Auschwitz' rationale for trust in reasoned progress. The disjunctions in our social life, the intellectual dislocations representative of Foucault's ideas, do mirror something of the 'disappointed condition of Enlightenment' reason. It is interesting to note that the movement from 'debate' to 'dialogue', albeit idiosyncratic to these specific references, suggests that the initial dismissal of Foucault by those critical theorists, supporting 
Habermas, has not been so simply achieved. Clarifying that debate about what is effective critical theory does provide new ways to examine the present state of our policy politics. His investigations into the 'radical contingency of discourses ... makes Foucault's "histories" forms of social critique, a fact seemingly lost on such critics as Habermas and Rorty' (Flynn, 1991: 169).

There is a growing body of more general social and philosophical scholarship that is reworking Foucault's ideas in relation to the discussion of the social (c.f., Harpham, 1994; Owen, 1995; Leonard, 1994, 1997; Tully, 1999a, 1999b). In a recent article Touey suggests that Foucault's well-known essay 'What is Enlightenment? is really his 'apology' to all those who accused him of having no agency. As Touey expressed it the:

... essay seems in large part addressed to those critics who claim that he has eliminated any such emancipatory critical project. Foucault insists that, on the contrary, he is very much within the critical and liberatory tradition of modern philosophy, it is just that, necessarily, he must go about it in a different way. "What is Enlightenment?" is an apology in the best Socratic sense: an argument on the part of Foucault that his life's work was not meant to destroy the critical tradition handed down by the Enlightenment but to reinterpret it in contemporary terms. (1998: 88)

What necessarily made Foucault articulate his particular defence of a 'liberatory tradition' in contradistinction to the usual canons of Enlightenment reason is discussed throughout this thesis. Touey's interpretation of this essay as 'apology' is an interesting one shared also by Allen (1998). Whether it is indeed a kind of 'apology' needs some investigation for certainly Foucault's challenge to that canon was extreme.

It is too easy to dismiss him as 'standing nowhere' and thus of little relevance to a genuine critique of contemporary neo-liberalism (c.f., Taylor, 1986). Equally, it might be too eliding of Foucault's overall work to assume that he was never 'outside the tent' and that this essay is an 'apology' in order to be seen to have been part of the Enlightenment project all along! ${ }^{x v i}$ However, Touey's interpretation does point towards an application of Foucault's work that assumes that he can speak to our hopes for the future. As he concluded:

... we may put Foucault aside because of the stress he puts on our hopes for a progressive philosophical project. But we may also use the aporias he creates as a chance to examine our own revulsion at them, our instinct to reject any philosophical outlook that suppresses our instinct to engage in traditional forms of critique. For that impulse is itself an effect of history - a trope, a structure that we follow naturally but is the result of a complex series of events in politics, economics, and social and intellectual history. To engage in a genealogy of our critical impulse, to try to discover its contingent historical genesis, is not to try to tear it down ...To admit the unresolved ambiguity of the 
situation is to set ourselves on a new course of philosophical inquiry into the problem of human freedom. (1998: 102-3)

Asking the question about how much it is possible to 'rely' on the various 'fortresses of order' that buttressed previous arguments for welfare states is imperative. Particularly so, if we are to develop any new social 'voice', any new possible perspective with which to think again about that which we have so ardently defended as the truths of our social dispositions. We can hardly claim to have got it right - despite that being the underlying assumption within a neo-liberal view of common sense social policy arrangements.

While I will apply and discuss the relevance of Foucault's ideas to this task of reexamining welfare politics as the 'antinomy of our political reason', clarifying the intellectual ferment about Foucault, provides a separate reference point. It serves as a commentary about the intellectual 'tools' we can apply to critique the normative discussions that so often pass for social policy theorizing. Foucault refused to buy into the easy dichotomies of citizenship theory, where the State is seen as intrinsically oppositional to more fundamental fraternal social bonds. He preferred to examine the processes of rationalization that 'formed' such concepts as 'citizen' and 'fraternal bonds'. It is an examination represented in his notion of 'limit-experience' - where his analysis of the processes of subjectification calls the whole structure of our welfare politics into question. It leads on to his central thesis of governmentality, so essential to critical reflection within social policy that we should first understand these processes in order to see how we might breach these limitations.

\section{Conclusion}

At first glance, applying Foucault's ideas to any possible theoretical development within social policy seems a forlorn task. As we shall see, there is a considerable body of opinion that is hostile to that possibility - including, at times, his expressed opinion. After all, he was seen to be the architect of a new 'unreason' that has delivered social debate into a recursive labyrinth from which there can be no escape (c.f., Taylor, 1986; Fraser, 1989b). Nonetheless, in all of these 'squabbles', it is the very strength of the polarized opinion about Foucault's intellectual standing that continues to exercize us, as well as the value of his extraordinary body of sadly truncated work. How we might be able to apply his ideas does need to respect his unwillingness to write explicitly within the Western canon of Enlightenment reasoning (c.f., Touey, 1998). 
Given the nature of his difficult and sometimes idiosyncratic prose it is so easy and tempting to quote him as if this sentence or perhaps that paragraph provides the textual proof of what it was he really intended. I am mindful that this is an academic problem that will not go away, no matter how astute our perspective or how we might couch it. That is why I have placed the next chapter on the various 'Foucaults' at the beginning of this thesis. I agree with Halperin's assertion that the:

... almost ritualistic invocation of [Foucault's] ... name by academic practitioners of cultural theory, has had the effect of reducing the operative range of his thought to a small set of received ideas, slogans, and bits of jargon that have now become so commonplace and so familiar as to make a more direct engagement with Foucault's texts entirely dispensable. As a result we are so far from remembering Foucault that there is little point in entertaining the possibility of forgetting him. (1998: 93-94) 


\title{
Chapter Three
}

\section{The Various 'Foucaults'}

\begin{abstract}
Poet, Romantic, Blakean heretic, romantic pessimist, imaginative rationalist thriving on the lure of the Platonic "One and Many", universalist terrified of the possibility of an empty nominalist universe, child of Hegel and brother of Nietzsche - Foucault is all of these. (Rousseau, 1972-3: 256)

I think I have in fact been situated in most of the squares on the political checkerboard, one after another and sometimes simultaneously: as an anarchist, leftist, ostentatious or disguised Marxist, nihilist, explicit or secret anti-Marxist, technocrat in the service of Gaullism, new liberal, etc.... None of these descriptions is important by itself: taken together, on the other hand, they mean something. And I must admit that I rather like what they mean. (Foucault, 1984f: 383-384)
\end{abstract}

The challenge that Foucault's ideas represented to the traditional canons of historical investigation, philosophical reflection and sociological analysis has sparked a fascinating and ongoing debate about 'who' or 'what' is Foucault? He developed a unique rhetorical and prose style, upset the traditional canons of scholarly reflection, and eluded 'easy capture' (c.f., Davidson, 1984; Flynn, 1987; Goldstein, 1994; Merquior, 1985; Megill, 1979, 1987; Murphy, 1984; Noiriel, 1994; Poster, 1982; Rajchman, 1983b; Roth, 1991). This chapter examines the polarized assessments and descriptions of the various 'Foucaults' - those separate and often contentious descriptions of him and his work that claimed to know what was his 'truth'. It continues and extends the theme of the previous chapter about where we might 'place' Foucault. Here the emphasis is on the range of interpretive opinion - the 'usage' of Foucault rather than any explicit discussion of Foucault personally.

Reflecting on the patterns involved in the polarized review of his ideas serves as a reflexive mirror of modern critical opinion. One such critical 'image' of him was that he was not consistent and that the grounds and focus of his concerns changed over time (c.f., Megill, 1985; Merquior, 1985). Why Foucault per se should shoulder such a 'burden' reflects some of the failed 'hopes' that he might have articulated a new critically normative view of political change (c.f., Allen, 1998; Bernstein, 1995; Rorty, 1982, 1990 , 1991). For example, Hiley almost wistfully describes the aborted personal meeting where Foucault had invited Habermas to discuss Kant's famous essay 'What is Enlightenment' as 'the lost intellectual opportunity of the decade' (1988: 89). 
Whatever 'synthesis' or rapprochement might have been engineered between Foucault and the Frankfurt School remained stillborn. Habermas recognized that Foucault was 'rich in values' ... not least of all because of the seriousness with which he perseveres under productive contradictions'. However, he still adhered to the commonly held belief amongst the Frankfurt School that Foucault's normative inconsistency forbade him from 'asking what makes ethical questions possible at all' (1984: 6; Honneth and Joas, 1988 : 150). As Philp describes, although 'strong threads of consistency can be recognised through ... [Foucault's] works, he repeatedly went back over his earlier works and reworked his ideas - much to the delight of his many followers, and to the confusion and irritation of his equally numerous critics' (1985: 68).

Shouldering Foucault with the burden to 'explain' his intellectual shifts is facile at one level and yet instructive at another. For example, Nehamas' opinion that Foucault's 'progress from the detached quasi-structuralist of the 60's to the committed and nihilistic intellectual of the 70 's to the paradoxical neohumanist of the 80 's is a parable of our time' sets out the reflexive nature of such Foucaultian criticism (1993: 36; Hiley, 1988). Certainly he was bemused with the demands that he ought to have been consistent (c.f., 1991d). He was 'amused by the diversity of ways l've been judged and classified. Something tells me that by now a more or less approximate place should have been found for me' (1997c: 113). He could at other times be quite dismissive and teasing of the concerns that he was inconsistent, evincing a tone that borders on open hostility (1972: 17).

There is no doubt a degree of personal animus in the introduction to The Archaeology of Knowledge where he lists a series of questions that he speculates have already arisen about him and to which he makes reply. I list them in bullet point for emphasis:

- Aren't you sure of what you're saying?

- Are you going to change yet again, shift your position according to the questions that are put to you, and say that the objections are not really directed at the place from which you are speaking?

- Are you going to declare yet again that you have never been what you have been reproached with being?

- Are you really preparing the way out that will enable you in your next book to spring up somewhere else and declare as you're now doing: no, no, l'm not where you are lying in wait for me, but over here, laughing at you? (1972: 17)

$\mathrm{He}$ answers these questions about his real intent by suggesting that his critics should respect the efforts he puts into his writing and understand (perhaps if they can) that he is 
entering a confusing and elusive labyrinth that will deform any typical interpretive 'itinerary'. He ends this dismissive 'repartee' with that famous intellectual joust to his erstwhile critics that he was 'not the only one who writes in order to have no face'. Together with the injunction that his readers should not ask who he was and that equally he should not be required to 'remain the same'! He mockingly concludes that such demands for consistency should ultimately be left to 'our bureaucrats to see that our papers are in order' (1972: 17).

It was such flights of verbal bravado that led many critics to the conclusion that he had spent too long with Nietzsche! For example, Megill's (1985) depiction of Foucault as one of the 'Prophets of Extremity' associated with Nietzsche, Heidegger, and Derrida represents one important view of Foucault's private and idiosyncratic journey. Much of the counter-reaction to his ideas relegated him to the 'mists' that it was assumed befell anyone taking the same journey into Romantic individualism. They became Nietzschean 'knights of autonomy' and were thus lost to reason (Rorty, 1991: 194-5; c.f., Megill, 1985; Merquior, 1985; Minson, 1985; Owen, 1984; Rorty, 1990; Schneck, 1997; Thiele, 1990, 1991).

Speculating on what he really meant by evincing such a hidden personal style is idle for his 'debt' to Nietzsche is clear (Foucault, 1984c; c.f., Nehamas, 1993; Shaw, 1999).

Deleuze argued that when Foucault developed his ideas of subjectification and 'limitexperience' he demonstrated he was a 'Nietzschean, discovering an artistic will out on the final line' (1995: 114). Faced with the question about his Nietzscheanism in an interview with Gilles Barbadette and André Scala in 1984 he agreed 'I am simply Nietzschean' (1985b: 9). Was this reply challenging, teasing, elusive or contemptuous?

Presuming to answer why he made those personal decisions is facile because his reasons remain subjectively hidden and in death absolute. It is, however, possible to assume that in promoting the notion of disengagement from 'authorship' (1977a) one of his ironic intentions was to challenge the expert controls, functions, and independent commentary of the disengaged and/or lofty intellectual (c.f., Kolodny, 1996; Nehamas, 1993). He explicitly stated that he wanted no Foucaultian 'disciples' (1991d) xvii and sought the apparent 'anonymity' of being a 'masked philosopher' (1988d; c.f., Rabinow, 1998). 
Foucault skewered the very same attributes implicit in such negative commentary made about his own political usefulness. He decried the 'privileged shelter' of such apparently objective stances (1972: 12) and would provide no surrogate, as Hacking declared, for any essentialist hope in fraternal humanistic reason (1981: 37). For example, Rorty, while praising Foucault's ability to master a useful commentary on a 'new set of dangers to democratic societies' dismisses him because he refuses to engage in the common humanity of politics. He was, Rorty wrote, 'trying to serve human liberty, but he was also, in the interests of his personal autonomy, trying to be a faceless, rootless, homeless stranger to humanity and to history' (1991: 195).

Rajchman held a similar view (termed the 'interpretive dilemma' by Hiley, 1988: 89) when he suggested that Foucault 'was someone who supported many struggles and yet found it next to impossible to speak the language of morality' (1986: 166). He had, it was suggested by Taylor, no Augustinian 'inwardness' and therefore no ability to contribute to that which is common to all - our humanity (1986: 77). Rorty's view has more of the 'feel of truth' than Taylor's personal rejection in that Foucault's style does lend credence to the idea that he was an intellectual nomad (c.f., Patton, 1989, 1994). He rejected the modernist demands that he clarify and specify his arguments. Rajchman's assertion that Foucault had no 'language of morality' reflects the first 'flush of criticism' - particularly those indebted to Habermas (c.f., Ashenden and Owen, 1999; Cohen, 1988; Fraser, 1992; Flyvbjerg, 1998; Honneth, 1995a, 1995b, 1997).

The idea that he was explicitly an antihumanist bears still more examination for these assumptions are reflexively revealing of the very presumptions Foucault would have us examine more closely. Such criticisms are ultimately about his use of ideas and his challenge to the inclusive liberal 'we' that he thought ontologically based and uncritical of the presumption that informs such common 'knowledge' of the inner moral life. These criticisms do not adequately reflect the trajectory of his thought, nor respect that he was unafraid to change his mind. In an interesting counter to Rorty's 'regretful' dismissal of Foucault as a Romantic quasi-anarchic 'poet' Colapietro contends that such sentiments represent an 'American evasion of Foucault' (1998; c.f., Hinkle, 1986). For example, Rorty's consideration of the value of Foucault to American scholarship was that most of the explicit Nietzschean anarchism had necessarily to be 'drained away'. He wished that Foucault 'could have managed, just once, what Walzer rightly says he always resisted: 
"some positive evaluation of the liberal state"' (1991: 194-5). He ought to have been shaping his arguments within their discursive understandings! For Shaw this was a misguided effort by Rorty 'to shoehorn Foucault into liberalism' (1999: 275).

Foucault had little patience with any notion of transcendent or foundationalist humanism. He shared 'with Wittgenstein the sceptical or therapeutic aim of removing what is assumed to be inner from ontology or nature and bringing it down to the earth of changing practices' (Rajchman, 1986: 168). However, the opinion that he had no 'common humanity of politics' does not reflect his actual political activity (c.f., McNay, 
you try to do something, not knowing what you're trying to do until you begin to fight' (1995: 88).

The particular place that Foucault held within the Parisian intelligentsia saw him enjoined in a 'battle' with Sartre for an intellectual status where such jousts are unique to French intellectual concerns (c.f., Fillion, 1995: 665; Flynn, 1997; Rybalka, 1985; Shaw, 1999). As Davidson somewhat cynically suggested, 'it is the cultural obligation of every twentieth - century French philosopher to seem brilliant' (1984: 109). When Foucault was admitted to life membership at the Collège de France he achieved the pinnacle of French intellectual aspiration for he was now part of 'the most prestigious institution in France' (Macey, 1995: 236). Such elevations have a particular meaning within France.

It is an ironic but understandable stance that having been given the accolade of a general or explicitly public intellectual Foucault should have teasingly spent so much effort arguing the place of 'a specific intellectual'. That this was a coded part of his public quarrels with Sartre was not lost on the Parisian intelligentsia, an observation reflected by all his major biographers (c.f., Deleuze, 1988; Eribon, 1991; Miller, 1993a; Macey, 1995). Megill, reviewing the cited references to Foucault, suggested that one 'needs a high degree of intellectual refinement to get much out of its "analytic of finitude' or its account of the "form of the human sciences". Yet in Paris in 1966 The Order of Things sold "like hotcakes" - an amazing 20,000 copies in four months - and turned Foucault into an intellectual celebrity over night. Such a reception was only possible within a highly coded intellectual environment, and even then it is hard to believe that many of its purchasers actually finished reading it' (1987: 122). ${ }^{\text {xvii }}$ Such was the view of a Parisian manqué!

The ready dismissals of Foucault, as Rorty and Taylor provide, run the danger of being reflexive in the sense that they are written out of a still questing stance that seeks confirmation that he is 'one of us'. Foucault's response to Rorty is fascinating and is a quite uniquely non-defensive statement of his own ethical intent. Such public rebuttal, however, was something to which he rarely succumbed - not quite the style of the 'masked philosopher'! Here he declines the 'offers' that Rorty and Taylor have made that he ought to locate himself within the generic 'we' of a liberal humanism. He equally declines to critique specific instances of destructive networks of power. Nor would he 
proffer what might replace these destructive institutions (Rorty, 1991: 197). What he argues does, nonetheless, create the grounds of possible a future critique:

... the problem is, precisely, to decide if it is actually suitable to place oneself within a "we" in order to assert the principles one recognizes and the values one accepts; or if it is not, rather, necessary to make the future formation of a "we" possible by elaborating the question. Because it seems to me that the "we" must not be previous to the question; it can only be the result - and the necessarily temporary result - of the question as it is posed in the new terms in which one formulates it. (1984f: 385)

Foucault would admit of no easy solidarity with some abstracted 'we'. He always asked what questions were implied in the choices to associate with some specific sub-group. For example, in the same article he describes his 'discomfort' at being appropriated by R.D. Laing and the early anti-psychiatry movement, simply on the basis of his thought in Madness and Civilization (c.f., 1991d, his revealing 1978 interview with the Italian journalist Duccio Trombadori). His stance was 'always to ask politics what it had to say about the problems that it confronted' (1984f: 385). The issue for Foucault was constantly to interrogate practices and not to try and argue from within any one set of opinions. As well as being concerned to analyse the problematic ways we have been constituted as who we are, he sought to raise questions about who we might become in our thinking as well as in our lives ... It is the question of a modern practical philosophy' (Rajchman, 1986: 179).

Part of the problem for modern scholarship was that Foucault's intellectual journey was one in which he was prepared to revisit and even re-examine the core of his argument. He refused to be 'tied' to a personal history of his thought. Some of his most telling comments, particularly about himself, were made in interviews. For example, in one discussion with Trombadori he said:

If I look today at my past, I recall having thought that I was working essentially on a "genealogical" history of knowledge. But the true motivating force was really this problem of power. Ultimately I had done nothing but attempt to trace the way in which certain institutions, in the name of "reason" or "normality", had ended up exercising their power on groups of individuals, in relation to established ways of behavior, of being, of acting or speaking, by labelling them as anomalies, madness, etc. In the end, I had only produced a history of power. (1991d: 145)

His investigations into how power has been exercized are represented in his oeuvre. In chronological order his early works were:

- Madness and Civilization: A History of Insanity in the Age of Reason, 1965 (published in French in 1961).

- Birth of the Clinic: An Archaeology of Medical Perception, 1973 (published in French in 1963). 
- The Order of Things: An Archaeology of the Human Sciences, 1970 (published in French in 1966).

- The Archaeology of Knowledge, 1972 (published in French in 1969).

- Discipline and Punish: The Birth of the Prison, 1977 (published in French in 1975).

- The History of Sexuality, Volume 1: An introduction, 1978 (published in French in 1976).

It is interesting to note that he was 'ambivalent' about the success of The Order of Things. It was not 'a point of arrival and conclusion' for him, nor did he 'resolve all ... [his] worries in that book' (1991d: 97). As he continues, 'The Order of Things is not my "true" book: it has its "marginality" compared to the depth of participation and interest which is present in and which subtended the others' (1991d: 100). It is obvious that he could happily write in order to 'deduce a methodology from the completed experience'. He said of his books (shortly before publishing The History of Sexuality) that:

Each of my books is a way of dismantling an object, and of constructing a method of analysis toward that end. Once a work is finished, I can, of course, more or less through hindsight, deduce a methodology from the completed experience. And thus, I happen to write alternatively what l'd call books of exploration and books of method. Books of exploration: The History of Madness, The Birth of the Clinic, etc. Books of method: The Order of Things, The Archaeology of Knowledge. And now, after having finished Discipline and Punish and while waiting to finish The History of Sexuality, I am setting down certain thoughts, in articles, interviews, etc. (1991d: 28)

Submitting Foucault to a tight historical exegesis about his methodologies (whether archaeology or genealogy) misses the point of what he set out to achieve. ${ }^{\text {xix }}$ Elucidating the periodization of his ideas and requiring him to be accountable for the changes from archaeology to genealogy and then to techniques of the self is unlikely to elicit or illuminate the real or essential Foucault. Searching 'for the 'true' Foucault, even adequate exposition is illusory' (Gane, 1986: 121).

It is a nice irony that having argued against the significance of the 'author' (1977a, c.f., Hollier, 1985) it is possible that Foucault, far from averting our 'gaze' from him, has established his very uniqueness! To argue that it 'is impossible to treat him as an authorial presence in his text' (Racevskis, 1980: 41) is absurd. As Nehamas rightly observed, Foucault 'did not make the silly claim that writers do not exist or that books get written by themselves, any more than his notion of "the death of Man" [Foucault's famous/infamous conclusion to The Order of Things] implies that people are not real. He was arguing, rather, that certain apparently natural ways of treating both books and human beings are specific to given historical periods' (1993: 28; c.f., Nehamas, 1986, 1987). He is, despite himself, a man of words, borne of ideas! ${ }^{x x}$ 
Foucault's famous 'elusiveness' is demonstrated nowhere better than in the well known prefacing quote and we would be churlish to deny his personal enjoyment! He does not easily allow himself to be 'captured'. Nor can he be held within any particular philosophical or sociological analytical system and it may be that an allusive application of his ideas best captures respect for his task. While he dismisses any single attempt to situate him he does assume that these independent but vain attempts, taken as a whole, do apparently 'mean something'. He does not explain why - only that he enjoys that collective 'something'. $x x^{\prime}$ That 'something', however, was unlikely to be personal in that it could bespeak Foucault himself. He was at pains to remove 'himself' from much of his arguments, but this was a deliberate stance that did not mean that he was personally untouched by his fame (c.f., Miller, 1993a). It reflects rather his desire to de-subjectify himself in the writing. What he means by this is that 'no matter how boring and erudite my resulting books have been, this lesson [to remove the 'author'] has always allowed me to conceive them as direct experiences to "tear" me from myself to prevent me from always being the same' (1991d: 32).

That he eludes such simple 'capture' is interesting in that it does raise deeper questions about whether his patterns of thinking can provide a new form of intellectual inquiry and commentary? Attempting to destroy, or at least reveal, the 'privileges' of any havens of the mind - part of Foucault's poststructuralist intent - does hint at the interrelatedness of our power/knowledge prescriptions and where we need to go to 'explain ourselves to ourselves'. It is this critical stance, represented in his analysis of the practices of knowledge, which seems so vital if we are to radically examine the taken-for-granted aspects of our welfare politics and the social policies that mediate and administer them. What is interesting is how the various efforts to 'solve the problem of Foucault' are reflexively valuable in revealing the practices of criticism. How social policy theorizing defends against trenchant criticism of its core social welfare practices is similarly revealing.

The issues of the 'one and the many' (Omnes et Singulatim, Foucault, 1981b) highlight the central questions that social policy theory and policy practice have often magisterially presumed to have solved through universal social legislation. An examination of the patterning of the efforts to 'explain' Foucault is, in itself, a different history of our present that we can use to rethink the practices of various sets of ideas - in this instance welfare 
politics and social policy. It is a different kind of 'mirror' that while apparently endlessly recursive still can bend back new ideas into our present political discussions about social policies. Foucault supplied us with 'watchwords, metaphors and neologisms to interpret our experience in novel ways. These interpretations may then help us in deciding how to proceed with the business of life' (Weaver, 1997: 46).

\section{Interpretive Fashions and Trends}

Trying to 'capture' and thus explain Foucault has almost developed into a separate academic industry (c.f., Sprinker, 1980). Some have suggested that it 'would be tiresome to give names to this new generation of Foucault's' (Dean, 1998: 182). We have, nonetheless, reached a stage in the critical appreciation of Foucault where the first flush of amazement at his brilliance (and the intellectual 'hagiography' accorded such texts as The History of Sexuality, Volume One) is muted and more considered (c.f., Halperin, 1995, 1998). In the ongoing revision of his impact on the world of ideas no one has yet put it better than Osborne who, rejecting an uncritical application of the 'trendy Foucault', nonetheless concluded that:

The sort of Foucault that appeals to me is not, anyway, the Foucault that appears in the cribs; the subversive continental philosopher, the arcane prophet of transgression, the iconoclastic poststructuralist, the meta-theorist of power, the functionalist theorist of social control, or the gloomy prophet of the totally administered society. These sorts of Foucault can all safely be forgotten. The Foucault that motivates [Osborne] ... is a more buttoned up animal: an ethical thinker with a Kantian heritage, a good modernist rather than a faddish postmodernist, a rigorous and not so conventional historical epistemologist concerned with the "immature" human sciences and, most unlikely of all, even something of an Anglo-Saxon empiricist manqué ... not the naughty, transgressive Foucault, but rather ... Foucault with his clothes on. (1998b: $x$ )

While, in one sense, Osborne is suggesting something less dramatic, less global in our application of Foucault's ideas - the more 'buttoned-up' Foucault - there is a gleam in the eye in such commentary. If I take him correctly then we do need an approach to our selves and our politics that is a little less serious, less unrelievedly sententious, more willing to cock a snoot at our constant desire to 'explain it right'.

Gloomy prophet or not, within sociology, Foucault's ideas have elicited both powerful support and equally forceful rejection (c.f., Bauman, 1992, 1997; Cohen, 1998; Dean, 1994a, 1994b, 1997, 1999a; Fox, 1998; Goldstein, 1984; Osborne, 1994; Turner, 1985). As Bové wrote, 'there is commonly such a buzz of contradictory comment going on around him - as his friends and enemies push him to the left, right, and center or 
sometimes out of the political spectrum altogether' (1988: viii). For example, Fox concluded that the 'translation of Foucault into sociology is largely vapid' (1998: 429)! xxii Only recently in the investigations of Foucault's thesis on governmentality can we see major sociological efforts within English speaking countries to consider the importance of French social theory.

Foucault's thesis of governmentality suggests that government 'is not the suppression of individual subjectivity, but rather the cultivation of that subjectivity in specific forms, aligned to specific governmental aims' (Garland, 1997: 175). It stresses that we are all 'active subjects'. Power is exercised through our willing participation. We are not simply victims of power for the exercize of governmental power is not 'objectifying' but 'subjectifying'. It is part of the form of rationalization that shapes the 'limit-experiences' of modernity whereby individuals are constructed with free choice 'as active subjects, and [which] seeks to align their choices with the objectives of governing authorities' (Garland, 1997: 175). It is this approach to the practice of governing power that leads Foucault into his theory of genealogical practice, to focus not on the valorization of the 'State', as such, but 'upon particular practices of governing, located in a variety of different sites' (Garland, 1997: 175).

Foucault's governmentality thesis is therefore one of the more exciting developments in current sociological thought (c.f., Allen, 1991; Burchell, G. 1991; Burchell, D. 1996; Dean, 1999a; O'Malley, 1993, 1996, 1999; Rose, 1996a, 1996b). That is not to say that Foucault had not been used in numerous sociological studies about the disciplinary aspects of power/knowledge. It is, however, to stress that the governmentality literature represents a unique attempt to take him seriously at the level of theory formulation already successfully undertaken in criminology and literary criticism (c.f., Cohen, 1985; Pratt, 1992; Bové, 1988; Garland, 1997). Some important efforts to apply Foucaultian themes to the development of a critical social policy stand out (c.f., Hewitt, 1983, 1992; Leonard, 1994, 1997; Squires, 1990, 1992; Hillyard and Watson, 1996; O'Brien and Penna, 1998a, 1998b).

Despite these efforts we still await a fuller analysis of Foucaultian themes within social policy, although some important work towards developing a genealogical approach to poverty has already been done in European social theory (c.f., Procacci, 1989, 
1991,1994). Stenson and Watt's recent work on governmentality and the presumed 'death of the social' (1999a, 1999b; and Stenson, 1999) are significant. While the various uses to which Foucault has been applied are considerable, my concern is more explicitly with the relevance of his ideas to social policy - to an analysis of risk and how his ideas might be used to shape a new critique of neo-liberal welfare assumptions.

\section{Explaining Foucault: Philosopher, Poet, Intellectual Nomad or What?}

What can we discern from the various attempts made to 'appropriate' him, both to provide an exegesis of his prose and to clarify his 'face'? Bové has already undertaken something similar in respect of philosophy and literary criticism. He said that:

... examining how ... academic circles function in dealing with Foucault, whose work is so forcefully critical of their knowledge politics, will provide a privileged insight into some aspect of these structure's workings while reclaiming something of the original critical force of Foucault's work. (1988: viii)

This discussion of the various 'Foucaults' seeks to clarify how the varied usage of his ideas illuminates his themes of power/knowledge, the formation of discourses and how they can be used to generate a more critical view of theory within social policy. Given my particular focus on social policy I am aware that there are many other 'Foucaults' than those examined here.

Two obvious and important ones that I omit are his undoubted importance as a gay intellectual (c.f., Bersani, 1995; Cohen, 1988; Halperin, 1995, 1998; Miller, 1993a) and his relevance to feminist studies, especially the 'politics of refusal' (c.f., McNay, 1992; Mill, 1994; Mouffe, 1995; Sawicki, 1988, 1991). There is already an extensive and important literature that critically examines Foucault's thought in relation to these areas (c.f., Aladjem, 1996; Cook, 1990b, 1993; Fisher, 1998; Fraser, 1997; Hartsock, 1996; Hekman, 1996; Valverde, 1999). To consider and take up these separate analyses moves the discussion away from my focus on social policy and risk and into a consideration of Foucault per se - that is not my prime focus. However, the themes that relate to resistance and the politics of difference, so essential to feminist and gay applications of his work, are clearly central to my analysis of social policies. My caveat is that a separate consideration of them is not justified in relation to my explicit focus but is intrinsically part of my overall thesis. 
It is little wonder that efforts to 'locate' and interpret Foucault have fallen foul, for as Gutting suggests, interpretation 'distorts because Foucault's work is at root ad hoc, fragmentary and incomplete' (1994: 22). Reading Foucault it is unclear whether he would have perceived that as criticism or praise! Certainly from within his analysis of 'limit-experience' he would have presumed that such 'fragmentation' was an accurate depiction of modernity. The 'forms of rationalization' that shaped modernity presented him with a 'tangle of problems' that he happily admitted he hadn't fully solved. He said of himself that 'I do not wish, as an intellectual, to play the moralist or prophet' (1991d: 172). He had no desire to create a new paradigm but stated that 'when I write, I do it above all to change myself and not to think the same thing as before' (1991d: 27). His rejection of the valorization of the 'author' was a strategic and not a personal choice (c.f., Nehamas, 1993: 28). Given such an orientation to his writing it is no surprise that books and papers about him have been written with such speculative titles as 'After Foucaul' (Arac, 1991) and the 'Foucault Effect' (Burchell, 1991) or 'What Was Foucault' (O'Hara, 1991). They are all, even in their titles, suggestive of how hard it was to encompass or follow in Foucault's footsteps.

It is as if the range of polarized opinion provided the private 'cloak' Foucault sought. Strategically, it was a rhetorical device to remind us that the very notion of authorship, and the supposed independent aspects of individual critique, might best be seen as elements of a wider discourse that has 'made us how we are'. xxiii It is part of his continued examination of 'limit-experience' and his analysis of the form of rationalizations that shape 'truth' and 'knowledge'. He examined reason as an intrinsic part of the discourses of rationality that shaped knowledge itself. He did not consider reason the arbiter of knowledge and morality but argued that it was explicitly part of the discursive ground, the social practice of knowledge building. It is this broader intent which has often had him labelled and dismissed as a structuralist or a nihilist, as having no ethical gravitas, providing no grounds for any social hope or moral community, or some other refraction of the critical checkerboard symbolism.

\section{What Manner or Nature of 'Foucault'?}

We turn now to a more detailed consideration of the question of the various 'Foucaults', for it is in the search to define him that we can see the patterning of the criticism of his ideas. He would not be so easily 'captured' in life and his intellectual legacy is still 
elusive. Understanding that patterning gives us new insights into the ways that knowledge and interpretive critique are determined. It is precisely this conjunction of power/knowledge that Foucault sought to explain. The 'language' that he uses is certainly abstruse and operates at several levels. While this has generated a wide range of criticism, concentrating on the single aspect of his recondite prose as a disparagement of him does not equate to a full evaluation of his work. It is a rather ineffectual defence of specific and venerated 'sacred cows'. His ideas need to be approached in a novel way. The elusive prose of the 'Masked Philosopher' is well captured by Merquior who suggested that Foucault's writings are 'strewn with gnomic utterances, tantalising hints, and a taste for verbal drama rather than logical argument' (1985: 56). Merquior's critical perspective is not without substance but, as with many analytical philosophers, the totality of it 'falls' precisely because it seeks to explain, to locate, to confine and thus, ultimately to 'know'.

The paradox of 'what was Foucault' lies more in our own uncertainties that we confront when reading him. There is a wildness of spirit in his work. It reflects both the longing to build, to have found 'solid' ground for our self-understandings and also requires us to deal with 'the singular randomness of events' - which undercuts the false security of various epistemological 'solid' grounds. Despite the appearance of such radical relativism in his arguments the paradox may well be that there is a 'common' echoing in Foucault. It may be possible to find in his ideas, after all, a way to respond to Derrida's apparent conundrum that 'the establishing of relations between differences is also the promised complicity of a common element' (1982: 112).

The 'dying in us' of unsatisfying language, the descriptive categories that confine and do not liberate, reminds us that we are 'the animal that loses its truth only in order to find it again, illuminated; the self-estranged who once again recovers the unity of the selfsame' (Foucault, 1997b: 98). This is not the prose or the sentiments of a complete nihilist or an anarchic destroyer. Nor is his prose that of a Romantic 'quasi-anarchist' as Rorty would have us believe, though one can understand why reading it led Rorty to the conclusion that Foucault was best described as a 'poet' (1991: 196; c.f., Flynn, 1991; Rousseau, 1972-3). It is rather the prose of someone very elusive, often deliberately so, as his position as a prominent French intellectual allowed him to be (1977b, 1997c; c.f., Beaud and Panese, 1995 on the 'trajectories of French intellectuals'). 


\section{The 'Shape' of Foucault's Various Masks}

In an interesting review article, discussing this question of the various Foucaultian masks, Descombes (1987) suggests that there are indeed several 'Foucaults' xxiv . He distinguishes four. Paraphrasing him he suggests that 'Foucault $l$ ' is a subversive historian - an 'archaeologist of the human sciences'. 'Foucault II', deeply affected by the events of May 1968 in Paris, is a 'microphysicist of power' who minutely examined the techniques of contemporary social control. 'Foucault III' turned to a 'comparative study of the pagan morality of the Greeks and Christian morality, with the aim of clarifying our own moral assumptions'. 'Foucault IV', Descombes suggests, offers two possibilities; one is a 'French philosopher whose unfinished system is reconstructed by Gilles Deleuze ... the second is a sort of perennial visiting philosopher in the US'!

For Descombes, the 'French Foucault and the American Foucault are not two sides of one and the same thinker: they are philosophers who hold entirely incompatible doctrines' (1987: 20). It is interesting to speculate whether Foucault would have been irritated or amused by such 'differentiations' - one suspects the latter. Such problems of consistency or focus were not of great consequence to him. As he said of any approach to his work:

All my books ... are, if you like, little toolboxes. ${ }^{x x v}$ If people want to open them, to use a particular sentence, a particular idea, a particular analysis like a screwdriver or a spanner to short circuit, to discredit, to break system of power, including perhaps even those that my books issue from ... well, so much the better. (Mottier, 1995: 27)

In general terms the question is whether Foucault can be considered a historiographer of knowledge (as Rorty, 1982 suggests) or a philosopher (as Deleuze, 1988 argues). ${ }^{x x v i}$ Foucault argued that 'what the philosophers say cannot be considered history (what passes through someone's head is a social phenomenon but does not belong to the

order of history' (1991d: 125-126). The question, therefore, which both Rorty and Deleuze were negotiating in their respective commentary about Foucault, is how to deal with his preoccupation with the effects of power. For Rorty, Foucault's genealogies were more significantly located within the methodology of history. ${ }^{x x v i i}$ For Deleuze on the other hand, claiming that Foucault is a philosopher was to lay claim to him as a 'visionary intellectual' within the French philosophical tradition.

The various 'Foucaults' and how these might be understood provide a context for my overall purpose setting out the elements for how the sociology of welfare and risk could 
be developed. Like all social theorists we can use him indiscriminately, as bits and pieces out of his 'toolbox'. As Descombes concludes, the 'American Foucault may take our concerns and practices very seriously. Yet it may be the 'anarchist' Foucault who keeps fascinating his readers' (1987: 21). It is not useful to seek a resolution of this interpretative conflict so much as to recognize the patterning that the respective dismissals take. Efforts 'to reconcile continental and analytic philosophy are at best bland, lacking the savour or pungency of either' (Hacking, 1989: 343; see also Rorty: 1982 for a full discussion of these differences and his argument for maintaining the unfinished 'conversation' of philosophy). That unfinished conversation needs some respect for the fact of difference and not some new synthesis that would transcend these differences. One way to respect the rhetorical difference of Foucault is to reflect on his use of language.

\section{Foucault's 'Visual' Language: The Rupture of Reason?}

What a 'reading' of Foucault requires is a willingness to embrace not only the logic but also the 'playfulness' of his ideas (c.f., Colapietro, 1998). Turner comments that 'it is difficult to know whether we are to take Foucault's obscurities seriously, since there is a sort of gaiety in the dark corners traversed by Foucauldian inquiry' (1985: 196, my italics). For example, he wrote that 'genealogy is history in the form of a concerted carnival', or consider this, 'knowledge is not made for understanding: it is made for cutting' (1984c). These phrases are 'word-pictures' which engage the mind deeply below the logical, or at least apart from the strictly verbal and logical.

'Seeing' Foucault is as important as 'reading' him and Turner touches on this in his recognition of his 'gaiety' but obviously is still caught up with his own vital sets of rationalizations that indicate an uncertainty about Foucault's attempt to 'defamiliarize' history. The logic of such analyses often seek to exclude the outrageous flights of Foucault's prose that draws us into the irrational aspects of our knowingness as well as respects the 'safe' patterns of our logical reason. English sociological analysis is 'uncomfortable' with such apparently radical relativism or equally with the notion that there can be any challenge to the continuous evolution of history. Roth argued that:

Foucault's critical history can be portrayed as an antihistory because it is attempting to make the present into a past which we leave behind, and not into a history which we tightly embrace as our own ... Foucault uncovers the past to rupture the present into a future that will leave the very function of history behind it; a future that will have no need 
of a past to be endlessly recaptured, but that will be situated merely "in the scattering of the profound stream of time". (1981: 44)

The English suspicion of French intellectual life (as representing 'a certain cant of words') is nothing new. Gordon, one of Foucault's most articulate English 'interpreters' suggested that 'many people know [sic] who Foucault is, but ... have difficulty in knowing what they should think about him' (1996: 253). Part of this difficulty is the result of an inability to respect or understand Foucault's celebration of the peculiar and the esoteric as a healthy caesura to the 'iron-cages' of Weberian or Freudian explanations. It is not too difficult to understand why English commentators consider this quote from Veyne to be barely comprehensible:

Foucault's importance is precisely that he is not "doing" Marx or Freud; he is not a dualist, he does not claim to be contrasting reality with appearance, as rationalism does when all else fails, with the return of the repressed as the reward. Foucault, for his part, strips away the reassuring banalities, the natural objects in their horizon of promising rationality in order to restore to reality - the only reality, the unique reality, our reality - its irrational, "exceptional", uncanny historical originality. (1997: 182)

It is easy to be 'irritated' by such an implicitly transcendent rhetoric. While the analytic cast of English social philosophy can dismiss such 'Continental' ideas of caesura or rupture, the attempt to 'break open' rigid analytical certainties must be taken seriously. At the very least posing a challenge to the rigid hegemony of contemporary political rhetoric serves a renewing function.

Foucault is an intellectual 'enrage' whose oeuvre was premised on rethinking the whole structure and pattern of social thought. He not only 'elevates' the esoteric but also undermines those justifications for the place of fundamental 'truths' in our various discourses. It is the second intention that causes the most critical reaction. His celebration of the unusual, the occluded and the forgotten, liberated 'history from the tutelage of epistemology' and 'showed that what history had hitherto excluded was that which made possible the very knowledge that history placed in the limelight' (Delaporte, 1998: 292). It was, in substance, a stunning attack on the arrogant and dismissive traditions of social analysis that relied on the super-ordinate notions of reason and criticism.

The 'problem' that was 'Foucault' for contemporary critical theory is that seeking to understand him by dissecting or requiring a certain epistemological reckoning of him is vapid. The founding stone of the Western intellectual tradition is that it 'exists in a state 
of continuous transformation ... [and] is ruled by evolution within continuity' (Poster, 1997: 135). Foucault laid siege to that continuity by revealing the practices that shaped such formative political knowledge. As he stated:

Nothing is fundamental. That is what is interesting in the analysis of society. That is why nothing irritates me as much as these inquiries - which are by definition metaphysical on the foundations of power in society or the self-institution of a society, etc. These are not fundamental phenomena. There are only reciprocal relations, and the perpetual gaps between intentions in relation to one another. (1989: 267)

The rigid discourses of common sense depend on the denial of reciprocal relations - all is to be subsumed into the 'normality' of market place winners and the 'abnormality' of losers. Foucault's emphasis on challenging all metaphysical explanations of social relations has, at times, seen his thought appropriated in neo-liberal discourses about individuality. There is a paradox at work here for while Foucault's importance lies precisely in his singularity - in his exceptional 'uncanny historical originality' - his analyses are not simple accounts of the value of individual privacy. Understanding what he means by such singularity requires respect for his work as a whole and a reluctance to privilege the single-focused 'toilers' who flail away at bits of his corpus.

The language of our social critique has become stale and pallid. It is caught within an endlessly recursive demand that any valid social critique must distinguish 'acceptable from unacceptable forms of power' (Fraser, 1989b: 33). The problem is that so much of that language implies a wistful voice, a longing for some sense of social solidarity that was enshrined in the citizenship expectations of the former welfare state (c.f., Turner, $1985,1993)$. Foucault may indeed not have succeeded in providing clues for how to overcome the problem of ineffectual normative social critique. While this was never his intent (c.f., Garland, 1997) it is, nonetheless, useful to raise the question whether his oeuvre can challenge the hegemony of neo-liberal common sense. The 'invitation', if such it is, to use his books and his ideas like tools out of a toolbox is both possible and yet may be illusory. It may not be the equivalent of the old aphorism of 'beware the Greeks bearing gifts' but it can be seen as a clever foil aimed at the heart of precisely such dissection or use of his work.

The irony is that we cannot but use his ideas as 'bits and pieces' because he provided no overall explanatory paradigms and he explicitly 'resists' any new paradigmatic use of his ideas (Garland, 1997: 193-194). We can, however, decline to assume that any one 
particular quotation actually does encompass his intent. If we are to attempt an overall consideration of Foucault then he cannot simply be approached in terms of the prose itself. The question is whether there is an overall intent that is not exclusively logocentric that needed to be 'seen' as well as articulated. This notion then of 'seeing' represented the 'space' surrounding precise discourses that Foucault so often alluded to in his use of spatial language and metaphors. What it might mean for social theory to 'take him whole' is an interesting speculation; hence we might say of most critical commentary 'Ceci n'est pas Foucault'!

Deleuze notes that in his early work Foucault was preoccupied with how disciplinary processes were deliberately 'visible' before they were 'articulated' into the closure of punishment. Thus discursive practices (that which must be 'seen') precedes any the non-discursive practices (that which must be 'said' or 'done'). These disciplinary processes reflected, in Deleuze's own idiosyncratic prose, 'a system of light before being a figure of stone'. He suggests that the 'form' that haunted Foucault's work was 'the form of the visible, as opposed to the form of whatever can be articulated' (1988: 32; see also $50 \mathrm{ff}$.). As he said:

Visibilities are not forms of objects, nor even forms that would show up under light, but rather forms of luminosity which are created by the light itself and allow a thing or object to exist only as a flash, sparkle or shimmer. (1988: 52)

This distinction provides an added understanding - a fresh 'light' - to our understanding of Foucault's subsequent analysis of power/knowledge. It is this 'theory of visibilities', knowledge that is initially related to display (to the discursive rather than the nondiscursive; to that which 'breaks open' rather than to that which confines or contains), which establishes Foucault's core argument that knowledge/power is both capillary and ubiquitous. An identifiable Foucaultian archaeology 'must open up words, phrases and propositions, open up qualities, things and objects', argued Deleuze (1988: 53).

Narrowing this to the focus of this thesis my concern is to see if welfare rhetorical and cultural change similarly reflects this distinction between the 'visual' and the 'spoken'. In what ways might welfare discourses reflect the 'opening up' of discursive display (the 'evils and perils of dependency') before being confined in new sets of non-discursive elements? Positing a relationship between discursive and non-discursive analyses of welfare dependency, based on various sociological theories of risk, confronts neo-liberal political analyses of common sense. 
Deleuze provides, in this analysis of the 'visible' and that which can be articulated, one obvious reason why Foucault cannot be contained within the boundaries of contemporary analytical philosophy. Perhaps it is not too fanciful to imagine that we need to 'see' Foucault's prose before we can 'understand' it? These 'word-pictures', pivotal to the uniqueness of his prose-style, evoke a 'yes' that is not rational but comes from the 'otherness' to which he often refers. Together with the allusive conception of 'otherness' is Foucault's insight about 'rarity' or 'scarcity', mentioned earlier, which he applies to his idea that our 'speaking' can never be finished. For example, in the play Vita \& Virginia, Virginia Woolf, reflecting on her writing, states:

I believe that the main thing in beginning a novel is to feel, not that you can write it, but that it exists on the far side of a gulf which words can't cross; that it's to be pulled through only in a breathless anguish. (Atkins, 1993: 28)

The value of Foucault's oeuvre, ultimately, is that such insights enliven our imaginations (c.f., Connolly, 1993a). He presents, as Deleuze imaginatively describes, 'a theatre of statements, or a sculpture made from articulable elements, 'monuments' and not "documents" (1988: 54). Foucault seeks to dance at the carnival of knowledge as well as deal with the sharp and possibly dangerous consequence of so doing. There is a cost to ideas - the carnival might reveal that what we know is not so certain! In the Archaeology of Knowledge he set out his objection to the historian's reliance on the 'document' as such:

... scholars have asked not only what these documents meant, but also whether they were telling the truth, and by what right they could claim to be doing so, whether they were sincere or deliberately misleading, well informed or ignorant, authentic or tampered with. (1972: 6)

Foucault's problem with this is not just with the legitimacy of the historian's craft but also with the overall intent of the practice of that craft. It is this practice, and not the explicit or verifiable content of the document, that he attacks. Accordingly, he rejects the power of the canonical document that hints at a 'past from which they emanate and which has now disappeared far behind them; the document was always treated as the language of a voice since reduced to silence, its fragile, but possible decipherable trace' (1972: 6). It is the 'ferreting' complexity of historical analysis, based around that belief in continuity, one that promises the illusion of a former lost 'truth' that needs to be examined. $\mathrm{He}$ argued that the notion of the 'continuity of history' is a massive fiction that dictates so much of our contemporary consciousness:

... history, in its traditional form, undertook to 'memorize' the monuments of the past, transform them into documents, and lend speech to those traces which, in themselves, 
are often not verbal, or which say in silence something other than what they actually say; in our time, history is that which transforms documents into monuments. (1972: 7)

Historical investigation, thus conceived, was primarily oriented towards explanation - to finding the 'words of truth' and removing ambiguity and discontinuity. For the traditional historian discontinuity 'was the stigma of temporal dislocation that it was the historian's task to remove from history' (1972: 8).

What Foucault postulated, however, was a vastly different view of history where discontinuity, far from being that which must be removed, had now to be integrated into the 'discourse of the historian'. It was not, he argued, 'an external condition that must be reduced'. On the contrary, discontinuity was intrinsic to the historian's 'working concept'. Foucault thus established himself as an anti-historian who sought to 'invert the signs' so that discontinuity 'is no longer the negative of the historical reading (its underside, its failure, the limit of its power), but [is] the positive element that determines its object and validates its analysis' (1972: 9). He thought these discontinuities needed to be 'seen' and not always articulated in explanatory series or categories of reason. Such a 'seeing' implies a recognition and acknowledgement and not always an explanation.

The value of Foucault is this ability to point towards the ways in which the politics of obviousness and common sense may be re-visioned. He provides a method to raise the validity of the exceptional within the normative power of neo-liberal politics. His analysis of power/knowledge provides analytical tools to investigate how 'standards of coherence and intelligibility ... function as a kind of disciplinary "common-sense"' (Scott, 1996: 9). Scott too establishes historical reflection as inevitably entwined within 'the pursuit of an ever-elusive "real" [that] leads to new objects of knowledge and new interpretations that reorganize reality' (1996: 9). It is in this elaboration of rarity and exceptionality that Foucault can be 'aligned' with the normative expectations of current Critical Theory. After all, privileging 'rarity' has some coherence with Honneth's paradigm of recognition. That Critical Theorists have so often been at odds with Foucault's view of 'History' is an additional theme in this thesis that requires further explication of this apparent impasse the anti-historian, yet another 'Foucault'!

The differing uses of him represent various 'gatherings' from his toolbox and, consequently, differing representations of his ideas. What is perhaps more clearly 
needed in respect of Foucaultian scholarship is more exegesis of what he actually did argue - given that such a task is very elusive. The specific focus of this thesis is to consider Foucault in relation to social policy and risk. While that cannot exclude consideration of his overall intellectual impact within late modernity there will be aspects of the 'philosopher' and the 'historiographer' that bear only tangentially on this specific intent. What is crucial to the articulation of difference and to 'not being governed thus' is the way such ideas are 'seen' and not necessarily 'articulated'. Deconstructing the dictates of neo-liberal common sense that determine the analytical structure of contemporary welfare rhetoric draws on the power of Foucault to articulate a 'vision' of the other.

\section{Hacking's Singular Vision}

Amongst all the current commentaries on Foucault lan Hacking's expresses a respectful but particular independence. One senses that Hacking has captured the 'feel of Foucault' and he always paid tribute to him even when he disagreed with him. For example, he regularly acknowledged 'the profound influence of that wonderful thinker on my work. I used his thoughts but did not copy his vocabulary' (1998b: 86). At an earlier point in a whimsical, perhaps consciousiy self-deprecating manner (but mindful of the task) Hacking said that any commentary on Foucault needed to respect:

... one of Addison's warnings in The Spectator [291, Saturday $2^{\text {nd }}$ February 1711-12]. 'A few general rules, extracted out of the French authors, with a certain cant of words, has sometimes set up an illiterate and heavy writer for a most judicious and formidable critic'. (1984: 119)

His perspective about, and application of Foucault's ideas, has a singularity and a rhetorical power of their own such that Hacking's 'Foucault' bears some examination in its own right. His particular vision was to see how Foucault's task was not as nihilistic or as esoteric as is often argued. Hacking believed that he 'was in the terrible predicament of being rich in values and able in action, yet at the same time asking what makes the ethical question possible at all' (1986b: 238). The fact that asking such questions about 'limit-experience' earned him scorn is instructive in its own light. It is as if the Kantian notion that we construct individual ethical positions 'fitted' within a teleological intent but that Foucault's ethical questions about how we construct our discourses of morality were sufficient to 'bring down the temple'. 
It is hard not to see such harassing reactions as paradoxical. They are representative of a flawed and anguished self-conscious 'certainty' rather than a careful questioning of the nature of his ethical concerns. In an amusing anecdote Hacking recounts how just before David Hume's death the rabble crowd wanted to know when and if Hume had recanted of his professed atheism. He similarly wondered how long it might be 'before the solemn clamour of the intellectuals' attacking Foucault might sound as 'quaint as the baying of the Edinburgh mob' (1986b: 238). ${ }^{\text {xxviii }}$

Hacking's most clear association with Foucault's ideas can be seen in his theorizing about the significance of statistical analyses to construct the complex discourses of the modern state - how people are 'made'. Part metaphor, part carefully argued fact, Hacking's thesis has the ability to enliven the past and renew our jaded future hopes. He suggests that Foucault can be reread as a 'storyteller' who creates a 'connection between certain kinds of description coming into being or going out of existence, and certain kinds of people coming into being or going out of existence' (1984: 122). The construction and reification of populations adds considerably to an analysis of the hegemonic rhetoric of neo-liberalism particularly how the auditing function of statistical researches - Hacking's imaginative phrase 'making up people' - 'has profoundly transformed what we choose to do, who we try to be, and what we think of ourselves'.

Hacking argues that 'enumeration requires categorization, and ... defining new classes of people for the purposes of statistics has consequences for the ways in which we conceive of others and think of our own possibilities and potentialities' (1990: 6). Developing links between the disciplinary technologies of Foucault and how this 'makes up' the welfare client is a necessary obverse to all of those arguments that seek to justify and support autonomous individualism. Foucault posed the possibility of a relationship of power/knowledge (a particular savoir) between how specific populations were to be governed and how the resources available to governments could be most efficiently used. The political mechanism for achieving this was, he argued, dependent on the ability of the state to form the individual as an object of knowledge. Governing through individuals and their complex patterns of individual allegiances (their solidarities) became the norm of these new aspects of political control. The forms of political coercion became personal. 
Hacking's musings about what comes first, the discovery of the methodology or the need to control and measure, raise sets of questions about meaning and intent that are reflected in these Foucaultian assumptions about disciplinary society and the 'gaze'. 'Great webs of bureaucracy', Hacking suggested 'evolve endless ways to count and classify people. Birth, death, sickness, suicide, fertility: these inaugurate the modern era, the era of statistical data' (1981: 34). Hacking often depicts his work as poring over dry as dust statistical tomes but informed by the brilliance of Foucault to find oddly esoteric material and form them into new associations in his elaboration of the 'science of counting'.

His genius, as Hacking argues:

$\ldots$ is to go down to the little dramas, dress them in facts hardly anyone else had noticed, and turn these stage settings into clues to a hitherto unthought series of confrontations out of which, he contends, the orderly structure of society is composed. For all the abstract schemes for which Foucault has become famous, he is also the most concrete of writers. He is a fact-lover. (1986a: 28)

In his various conceptions about 'making up people' - the manifold ways in which various populations are reified out of singularities - it is interesting to note that Hacking juxtaposed 'making up people' with 'making up the world'. As he claimed:

... we 'make up people' in a stronger sense than we make up' the world .... Because the objects of the social sciences - peoples and groups of people - are constituted by an historical process, while the objects of the natural sciences, particular experimental apparatus, are created in time, but, in some sense, they are not constituted historically. (1984: 115)

This distinction between 'making up people' and 'making up society' sets out a similar approach to the nature of scientific and historical knowledge which preoccupied Foucault. He was concerned to elucidate the practices of how we form ourselves as subjects; in Hacking's words 'the interrelations of 'power' and 'knowledge' that literally constitutes us as human beings' (1984: 124). He does not stay 'locked in a cell of words' but through such intellectual work 'directs our attention away from our talk and on to our practices' (Hacking, 1984: 121).

This painstaking discussion of the practices of thinking leads Hacking to assume that Foucault is less fascinated with words as such rather 'than with people and institutions, with what we do for and to people' (1984: 121). It is the 'action' or the 'practices' of such investigations that is important, not that they constitute some new explanatory paradigm. 
They reflect aspects of Deleuze's analysis of how we must also 'see' Foucault's ideas. As Hacking argues:

Although we may find it useful to arrange influences according to Foucault's poles and my vectors, such metaphors are mere suggestions of what to look for next. I see no reason to suppose that we shall ever tell two identical stories of two different instances of making up people. (1986c: 236)

Criticism of Foucault that neglects the nature of this intent and tries to compel his arguments into a Procrustean bed of its own making reveals the false absorption into its own explanatory epistemologies. Such criticisms, Hacking assumed, are 'trapped within the cell of [their own] words': a form of hermeneutics that Foucault rejects. What such traps entail and their entrancements to our preoccupation are vividly expressed in Hacking's insight about 'Foucault's fork'. He describes it as a 'teasing device' that 'surprises us by stating that competing bodies of belief have the same underlying rules of formation' (1979: 41). Again, if such an assessment of Foucault is sustainable, and I think it is, labelling him as a nihilist reflects a precursive 'need', 'desire' or 'wish' and denies any ethical intent to his thought. It represents, in part, a defence of 'overt hypotheses' and 'written out deductions' that encapsulate strongly defended differences that Foucault seeks to find ways to associate rather than differentiate. At the core of their differences they are the 'self-same'.

In some ways the task he set himself attacks the formerly heroic defence of 'truths' that were seen as essential to a philosophical humanism (c.f., Hooke, 1987). He maintained that knowledge could not be grounded in some foundationalist human nature but rather in beliefs about knowledge (Paden, 1987: 135; c.f., Bovè, 1980). In Hacking's terms Foucault does have a 'noble obsession with what he takes to be oppression'. Foucault's 'heroes take a new form. Hope is no longer primarily in the lightening flashes of artistic genius but in the struggles and suffering of marginalized individuals and groups' (Gutting, 1994: 24). By surveying an extraordinarily disparate range of information in respect of various discourses of knowledge Foucault ushers in an 'anti-heroic' view of intellectual excellence. Studying the practices of such knowledge 'edifices' leads Foucault into 'a vast terrain of discourse that includes tentative starts, wordy prolegomena, brief flysheets, and occasional journalism' (Hacking, 1979: 42). 
The problem of such investigations is, as Hacking concludes, that:

Foucault's "revolutions" (he does not use the word) are, on the surface, spontaneous events that are so widespread, and so lacking in individual models, that we come to fear that his inquiries will degenerate into vague and unexplanatory waffle about the spirit of the times. (1979: 46)

Hacking's conclusion that 'attempting to understand how objects constitute themselves in discourse must be a central topic of the theory of knowledge' is important (1979: 51), and is reflected in the plethora of discourse analyses. That they have been used to bolster differences and not to take account of 'Foucault's fork' is one aspect of the continuous search for certainty or implicit teleological intent. However, all such processes, Hacking concludes, reflect the fact that there:

$\ldots$ is of course a rich plethora of things around us, really existing anterior to any thought. Moreover we cannot help but sort many things as we do: we are, it seems, made to sort things much as we do. Not only translation and mutual understanding but also our sheer existence seems to depend upon this fact. (1979: 50)

Despite the idiosyncratic nature of his own reflections, reading Hacking on Foucault demonstrates that he is both critic and intellectual companion. Hacking's analysis accords with Foucault's own expressed position, contained within his thesis of 'limitexperience' that we cannot know the 'ideal Man of Reason'. This willingness to take such a 'journey' with him is an extraordinary accolade and one that stands irrelevant and alienating. Hacking seems neither surprised nor concerned about his 'unsettled nature' or his 'famous changes of mind':

Foucault, let's say, has been completing a dialogue with Kant. Each question of Kant's is deliberately inverted or destroyed. "What is Man?" asked Kant. Nothing, says Foucault. "For what may we hope?" asked Kant. Does Foucault give the same nothing in reply? To think so is to misunderstand Foucault's reply to the question about Man. Foucault said that the concept of Man is a fraud, not that you and I are nothing.... Optimism, pessimism, nihilism, and the like are all concepts that make sense only within the idea of a transcendent or enduring subject. Foucault is not the least incoherent about all of this. If we're not satisfied, it should not be because he is pessimistic. It is because he has given no surrogate for whatever it is that springs eternal in the human breast. (1981: 37)

Foucault will provide no simple answer to what we may hope for' but rather wanted to indicate how our knowledge is bounded by the 'limit-experiences' that express our subjectification through all the rationalizations we readily assume to be the truth. His 'hope', if it could ever be expressed in this way, was that we should know what were the limits to reason. 


\section{Conclusion}

At the start of this chapter I suggested that arriving at a firm conclusion about any single interpretation of Foucault, trying to locate and define him personally, might be hopelessly fraught. We can leave him with his privacy and facelessness and, like him, make of ourselves our own private 'project'. We can, on the other hand, locate all his intellectual effort within, rather than without, the history of Western ideas. We can see that his moral search for autonomy was refracted in a way that despite such eminent critics as Taylor (1996: 77) does imply something of what we mean by a humanist vision of the future. Summarizing Foucault's impact, Roth suggested that 'his uncanny ability to see the limits of our present discourse from a point sometimes beyond it, and his inability, or refusal, to enunciate a praxis appropriate to that 'beyond' has been extraordinary. That has set out an agenda for a 'new politics' that refuses the 'comforts' of past certainties and does allow 'the search for some new morality' (1981: 45-46; c.f., Tully, 1999a, 1999b).

All that which was the various 'Foucaults' did not end with his death. The endless debate about 'what was Foucault' continues apace and reflects a hopeful restlessness that will not settle for easy accommodation to present political certainties. Despite his rigid enjoinders he did leave a legacy that is important as we consider our own entrapments and disciplinary 'realities' and ask again what does liberation mean? What space might there yet be apart from the 'iron cage' of our rational dispensations? It may well be that Rorty is right when he says Foucault was essentially a poet or at least 'a philosopher who claimed poet's privileges' (1990: 8). For Rousseau he remains, 'au fond ... a philosophical poet' (1972-3: 239). Given, as Gutting suggests, that the 'volcanic subtexts of mythological struggles almost entirely disappear [in the later Foucault] in favour of the cool exploration of aesthetic forms of human existence' (1994: 24; c.f., Dews, 1989) perhaps the poet is no longer claiming 'philosopher's privileges' but has become one in his own right!

Foucault challenged us to rethink the discourses about Man and the Whole of Society in order to examine the utility of such unquestioned constructs (c.f., Bernauer, 1987; Hiley, 1988; Philp, 1985; Poster, 1980; Ross, 1986; Shapiro, 1981). This was not an injunction to find a better form of discourse but rather than we should understand how we are 
governed. Hacking also had little regard for the notion that discourse analysis itself would yield up the 'answers' to our anguished search for meaning. As he contended:

... discourse does not do the work. Of course language has a great deal to do with the formation of an ecological niche, but so does what people do, how they live, the larger world of the material existence they inhabit. That world must be described in all its peculiar and idiosyncratic detail. (1997: 86)

Foucault's search for an answer to the 'detail' that Hacking describes was an ethical journey into the possibility that so-called paramount realities might be able to be deconstructed. He was not sure that he would arrive at the 'answer; but that does not mean that we don't have to ask the question' (1981: 240).

We should not, as Nehamas reminds us, be too literal about the 'death of the author' or the 'End of Man' (1986, 1987, 1993; c.f., Hiley, 1988; Parsons, 1988). It has been so easy for critics to bridle at these Foucaultian linguistic 'symbols' and thus label him an antihumanist. ${ }^{x x i x}$ They represented a way to get at the socially derived and constructed elements, the processes of rationalization that had created the slogans as necessary shibboleths. Foucault's criticism of humanism also involved his disdain for a word that had attracted too many varied and contradictory associations. As he argued, "the humanistic thematic, is in itself too supple, too diverse, too inconsistent to serve as an axis for reflection' (1984a: 44). Foucault implied no denigration 'of man's unique existence ... quite the reverse: Humanism is opposed because it does not set the humanitas of man high enough' (Burke, 1992: 114; c.f., Mahon, 1993). 


\section{Chapter Four}

\section{Reviewing Foucault: The Critical Oscillation}

The Order of Things ... has taught me (reminded me) of the essential and marvellous poetry of language, always brought back to itself where it is given its power of transformation: to say something else with the same words, to give the same words another meaning. (Howard, 1971: 22) ${ }^{x \times x}$

Who or what is 'Foucault' is still 'a site of continued contestation, struggle and appropriation' (Dean, 1998: 182). This chapter investigates another facet of this critical oscillation about Foucault through an assessment of the various reviews of his books. This list of the reviews of Foucault's major publications was worked through during research leave in 1999 at the University of Toronto, and those that I have used are included in a separate section of the bibliography. These reviews were complied from two main sources: the Book Review Digest available online through OCLC FirstSearch, and the Book Review Index 1965-1984 from Gale Research Inc. Not all of the reviews, especially the short paragraph reviews in book publishers' introductory lists (e.g., Best Sellers, Booklist, Bookworld, Kirkus Reviews and Publishers' Weekly), were relevant to my inquiry. My purpose is to consider the overall impact and the patterning of these reviews rather than to debate any one of them in any great detail. That would require a separate piece of research. ${ }^{x x x i}$ These reviews do provide patterned examples of how Foucault was initially assessed outside of France. The idioms and assumptions applied in them, and whether we can reasonably respond to these reviews generically, is the focus of this chapter.

One of the reasons that I have undertaken an analysis of the various 'Foucault's' is to see how the effort to locate and place him serves to counterpoint the patterning of social critique. Reflecting on the themes of these reviews indicates how rigidly our critical 'maps' have been drawn. It is also an opportunity to consider what impact Foucault's ideas might have on any revaluation or reconsideration of that 'critical rigidity'. Certainly much of this critical opinion reveals prejudices, assumptions, rigid patterns of analysis, fearfulness, even crude disdain of his person, which can only be seen as reflexive. They are misunderstandings that Deleuze considers malicious and stupid because there 'are some who can only feel intelligent by discovering "contradictions" in a great thinker' (1995: 90). Foucault's shifting theoretical emphases - from 'modes of inquiry' to 'dividing 
practices' and then finally (but truncated because of his early death) to ways in which we 'turn ourselves into subjects' - does reflect something of the particular radicalism of late modernity' (Seigel, 1990: 274). Would that those who knew how clearly to comment on the 'subject' of Foucault could understand that!

Sometimes particular reviews of his books adopt an explicitly hostile or alternatively an enchanted stance, but often the oscillation and indecision about Foucault is expressed in the same review. Making up one's mind about Foucault was for some clearly quite a challenge! For example, Foucault's 'intent is suspicious at best and malicious at worst ... he speaks from a place that is new and strange and perhaps threatening' declared Poster (1997: 143). White, similarly uncertain, suggested that Foucault, as a 'prophet of the coming age of totalitarianism is either an exemplary exception to its oppressive power or a masochistic participant in the processes of mind that will bring it about' (1978: 172). The reader is left to choose! Then there is the vexed issue of Foucault's language. For some reviewers, like White and Poster, his prose was a calculated and ideological decision to obfuscate and deceive. While for others, like R. D. Laing who enjoyed his radical style, Foucault's was a 'new voice' of 'undoubted distinction' (1967: 843). Said captures a similar excitement about Foucault's work when he wrote that his style evinced 'high seriousness and eloquence' and, perspicaciously, that he combined great conceptual power with a kind of 'ascetic nonchalance' (1972: 2).

The paradoxes, neologisms and linguistic devices of his books were too troublesome, apparently, for many of his reviewers to resolve. Typical of that response is the following comment by Bossy reviewing The Order of Things: An Archaeology of the Human Sciences. 'Who is going to be able - and who exactly, you wonder, is meant - to read it' (1971: 775). Was Foucault, as Geertz suggests, that 'impossible object: a nonhistorical historian, an antihumanistic human scientist, and a counter-structural structuralist' (1978: 3)? Whatever or whoever Foucault was for these reviewers, that he garnered such a wide-ranging response was an impressive achievement! It is interesting how the comments about Foucault's intentions and meanings often use a form of descriptive language that echoes his own. For example, Geertz' prose with its complex juxtaposed associations is similar to Foucault's. ${ }^{x x x i i}$ The assumption that Foucault's prose was knowingly obfuscating and that he was deliberately toying with his readers is a conclusion drawn by some (c.f., Bossy, 1971; Friedenberg, 1965; Kermode, 1973; 
Zeldin, 1973). Some have argued that this reflects the problems of translation (c.f., Caws, 1972; Gordon, 1990a, 1990b; Howard, 1971). Nonetheless, the 'unmasked philosopher' did, at times, reveal himself and discuss his thinking, especially in that wellknown interview with Trombadori (1991d; c.f., Rybalka, 1985).

It is tempting to ask retrospectively the very 'human' question - did he read his own reviews? Impossible to answer, obviously, but we do have some evidence that he was at times angered by the reviewing of his work, and often puzzled (Foucault, 1991d; Bernauer, 1986). He did engage in a public spat with Lawrence Stone in the New York Review of Books in the edition of March $31^{\text {st }} 1983$, and, earlier, involved himself in public cut and thrust with George Steiner in 1971. The subsequent brouhaha with Steiner is discussed later as a coda to the overview of the extracts from the separate reviews. Scanning the range of problems that many reviewers had in 'locating' Foucault, as well as the rapturous reception he received from others, provides a valuable perspective about his ability to disconcert and challenge prevailing ways of thinking. It presents a different perspective on the various 'Foucault's' and demonstrates the variety of ways in which it is possible to draw upon his ideas and shape a critique of the normative assumptions typically expressed in social policy (c.f., Fraser, 1981; Leonard, 1997; Pels, 1995).

\section{Reviewing Foucault: What Manner of Task?}

This chapter brings together some original material only partly hitherto assessed as a whole by Macey (1993) and Miller (1993a) in their respective biographies of Foucault. Clark, earlier, had compiled an annotated bibliography but that was essentially a descriptive overview and citation list and involved no commentary or exegesis (1983). Megill (1987) has undertaken a review of the citation and usage of Foucault within the discipline of history. What I present here are extracts of the reviews of his major works. This is not essentially to weigh them in some balance, though I acknowledge an implicit commentary in the selection, but to provide an overview of the intriguing 'problem' that Foucault posed for those who would interpret and review him. ${ }^{x x x i i}$ Some of them are quite funny, others scurrilous, many striving for an understanding of Foucault that obviously eludes them. But all add to the 'drama' that is such a fascinating aspect of the ongoing consideration of the 'Foucault effect' on the patterning of our intellectual criticism and our awareness of the 'history' of the present. Said provides an interesting 
commentary on the phrase 'Foucault Effect'. Reviewing The Archaeology of Knowledge, he suggested that for Foucault:

$\ldots$ any form of understanding that sends one away to given or assured ontologically prior forms such as an author, a period, an idea, a source, a world-view - in short, a genealogy of order - discounts the presence of the evidence, its sheer persistence as event or as evidence, in favour of deterministic hypostatizations. Moreover these determinisms assume a privilege in the understanding without account being taken of their very circumstantial nature. (1974: 35)

Two 'central premises' govern Foucault's thought. The first was that 'most of the situations in which we find ourselves are products of history, though we are convinced they are natural facts' - his thesis of 'limit-experience'. This blinds us to the realization that our 'particular views, habits, and institutions are contingent'. As Nehamas, comments, Foucault 'had an uncanny ability to discern history and contingency where others had seen only nature and necessity'. The second 'central premise' 'which he modified in his later years, was a relentless suspiciousness (sic) of progress' and that all efforts to reform institutions - 'clinics, madhouses and prisons' - were doomed to perpetuate them. Foucault was always able, and indeed eager, as Nehamas thought, to examine the hidden and occluded aspects of progress and to argue that the price paid for such progress 'was never a bargain' (1998: 169-170).

This view of Foucault's fundamental negativity - a preoccupation with what Nehamas describes as the 'seamy side of the Enlightenment' - does reflect aspects of his initial research style but it has become something of a trope in respect of his overall focus. It swirls around as a critically reflective 'cloud' that sometimes blinded Foucault's reviewers and critics to any alternative view of his significance. Partly because of this negative cast Foucaultian scholarship has been denigrated as little more than a cultic or sectarian activity (c.f., Merquior, 1990; Scull, 1990). We will see later, in the tenor of so many reviews, how implicitly and explicitly xenophobic they are about the 'false' importation of 'impossible' and 'untranslatable' French intellectualizing into the context of English social theory. However, what that initially negative view of Foucault avoids is what Eribon in his biography (quoting Michel Serres) describes as a 'cry'. As he quotes Serres, 'at the very heart of the logical argument [in Madness and Civilization], at the heart of the meticulous erudition of historical inquiry, a deep love circulates ... This book, therefore, is also a cry' (Eribon, 1991: 117). 
Whether 'deep love' is the kind of description many of his English reviewers would subscribe to, his writings do embody something of a cri de coeur, albeit often an idiosyncratic one (c.f., Sennett, 1981). French intellectuals had less trouble than their English or American counterparts in considering that there is 'passion' in Foucault's ideas (c.f., Deleuze, 1995). That 'deep cry' to which Serres refers obviously involved aspects of his sexual orientation. One commentator sees this as a prefigurative aspect of Foucault's work (c.f., Seigel, 1990). But it also involves Foucault's clearly expressed general concern for the excluded - for he was not immune to the personal anguish such exclusions entailed. Rybalka (a personal friend) said that he 'was an écorché vif (a man skinned alive), an immensely likeable person who had been irreparably wounded and who was therefore incredibly modest about his person and his achievements' (1985: 197). This is not a typical perspective that we find amongst his reviewers, and perhaps not one that we might have expected of such an international celebrity but it was Rybalka's opinion that Foucault could be very 'hurt' by the reception of his work! Geertz, reviewing Discipline and Punish, thought Foucault expressed his ideas in a style that was 'imperious and doubt-ridden at the same time' (1978: 3).

Because his reviewers had difficulty in knowing how to respond to Foucault, and where to pitch their analysis, his work is often located in some isolated position that will admit of no companionship, no surcease. What that solitude means for him is often hinted at but little examined. Deleuze assumed that Foucault 'wanted to be left alone, to go where none but his closest friends could follow him. I needed him more than he needed me' (1995: 83). Sennett, in an article in the London Review of Books, has provided the clearest exposition of what this meant for Foucault where he discussed, in conjunction with him, the topics of sexuality and solitude:

We know solitude imposed by power. This is the solitude of isolation, the solitude of anomie. We know a solitude which arouses fear on the part of those who are powerful. This is the solitude of the dreamer, of the homme révolté, the solitude of rebellion. And, finally, there is a solitude which transcends the terms of power. It is a solitude based on the idea of Epictetus that there is a difference between being lonely and being alone. This third solitude is the sense of being one among many, of having an inner life which is more a reflection of the lives of others. It is the solitude of difference. (1981: 3 )

Reviewers of Foucault's work must distinguish therefore which of these 'solitudes' best depicts the 'Foucault' they wish to present. Whether it is the isolated and anomic 'Foucault', the 'Foucault' who was seen by so many to be a modern homme révolté, or the 'Foucault' who articulated the solitude of difference and, by so doing, sought to 
transform our knowledge and experience of modernity. We can, perhaps, see Foucault's solitude as most clearly approximating the third of Sennett's descriptions for while he was intensely private and resisted any generalizing of his personal assumptions he did give 'voice' to the excluded. This is particularly so in relation to his homosexuality which was an obvious fact of difference (c.f., Bersani, 1995; Cohen, 1988; Halperin, 1995, 1998; Miller, 1991, 1993a, 1993b; Seigel, 1990). He probed the forgotten 'solitude of difference'.

While Foucault's writing does demonstrate an elusive style, perhaps even at times an uncertainty (or perhaps that it indicated a mind racing from one 'seismic crisis' to another, as Deleuze (1995) suggested), there is always an ethical respect for those excluded, for whatever reason, from the opportunity to 'become themselves'. Rybalka contended that Foucault's epithet, apparently often made in private conversation - 'listen to the victims, not to the theoreticians' (1985: 197) - lay at the core of all his work. This sentiment that the excluded might have a voice is more than just ethical intent for it informed a major proportion of his work and the 'question of madness runs right through Foucault's work' (Deleuze, 1995: 104). As Bersani suggests, in 'contrast to the pallidly glamorous absorption in absence which has become the dominant fashion in academia, Foucault offers us rigorously traced diagrams of the real historical constraints under which we live' (1977: 20). It was, however, not just about giving a voice to the mad, the excluded or the imprisoned but also about knowing the processes of their exclusions. It involved recognizing the subjectifications that defined these exclusions as specific instances of 'limit-experience'.

Bernauer (a Jesuit and close friend of Foucault's) also suggests that the ethical features of his research work are revealed in his determination to know the 'forgotten', not the powerful. For example:

Michel Foucault was a thinker of prodigious passion and his words frequently flash with intense feelings and shrill formulations. He once expressed his astonishment to me about the violent denunciations his works sometimes provoked, I was surprised, for how could it be otherwise? His work sabotages both our culture's official portrait of the human being and the authority of the human scientists who are its guardians. He pressed on them a series of invitations to look beyond apparently liberal values to the many social and political strategies with which they merge and within which they might play roles not originally anticipated for them; to be more conscious of the limits of our modern sciences and of their ability to tell us who we are; to be less trusting that current concepts of freedom and dignity are self-evident and do not bring with them different enslavements. Behind his attack on systematic knowledge, often regarded as beyond question, was a 
deliberate strategy of subversion, he succeeded in conveying to his listeners and readers a feeling of entrapment within cages of ideas that would not be easy to escape. The rhetorical excess which sometimes accompanied that subversion often irritated and distracted critics from his purpose, which always remained liberation. (1986: 19)

In line with his argument about 'limit-experience' Foucault set out to erode our quiet reliance on existing political structures 'by making them manifest, by showing them to be neither universal nor coherent, and by tracing back their 'lowly origins'. This erosion might not be a sufficient condition for emancipation, but it may well be a necessary condition' (Baert, 1998: 124). He argued that there were limits to our certainties and that we were often engaged in activities that worked against the precise 'freedoms' considered essential to reasons' certainty. He did not believe that modernity contained the elements for freedom and he did, as Bernauer suggests, try to sabotage modernity's trust in reason as guardian. His theme of 'limit-experience' encompasses all these attempts to transgress our trust in the progress of history and reliance on the reasonableness of 'Reason'. His methodologies were designed to probe the irrational and the irrelevant: the minutiae of the lived lives of people who were not registered as important in the discourses of traditional historical analysis (c.f., Bernauer, 1987; Bernauer and Mahon, 1994).

In Foucault's 'new history', as Said outlined, 'there is no quasi-divine arché, or telos, no Weltanschauung, no smug continuity, no immobile structures' (1974: 30). There is nothing intrinsic that we can point to that can be elevated into some form of archetype. However Foucault is to be criticized, and his work addressed, he founded no sect nor would he support any hint of a Foucaultian 'movement', posthumous or otherwise (c.f., Eribon, 1991). He explicitly wished for no acolytes and eschewed any possible paradigmatic application of his ideas (c.f., Garland, 1997: 193-194; Aladjem, 1996; Ignatieff, 1984). For example, Pasquino, commenting on his personal response to Foucault's lectures, acknowledged that as he:

... demanded of everyone who attended his courses, I have followed him in my own way. And this, perhaps, is the paradox of Foucault's teaching: while he affected each one of us very deeply, he kept those closest to him from remaining faithful. (1993: 84)

There was an irony in his self-presentation. He could even happily pretend not to be the intellectual he so obviously was and, mischievously perhaps, informed Trombadori that he wrote only in order to 'change himself' (1991d: 27). Denying any possible exemplary function for his thought he once whimsically said 'I am a merchant selling instruments, a 
recipe-maker, a cartographer, one who maps out power relations and draws diagrams' (Bersani, 1977: 6). On another occasion he wrote that 'I am not a structuralist, and I confess, with the appropriate chagrin, that I am not an analytic philosopher. Nobody is perfect' (1981c: 3).

Obviously Foucault was not interested in 'the noisy appeal of a cult or doctrine, or apocalypse, or dogma', as Said argued. He was much more 'interested in the [private] responsibilities and offices of his method'. But above all, as Said argued, Foucault's work habits were prodigious - almost monastic. He was, Said stated, entranced with 'the untidiness and the swarming profuseness of detail' (1972: 6). This preoccupation with masses of previously unreported and unexamined detail, with odd and strangely juxtaposed material, led Foucault into a style of scholarship that would not pile up logical evidence, argument by patient argument, but rather demonstrated 'reckless, synthesizing moves'. It was a scintillating bravura performance, as Bersani argued (1977: 6). While there are no obviously anointed 'disciples' Gordon's conclusion, based on his review of the continuing and unabated Foucaultian academic 'industry' (c.f., Megill, 1987), that Foucault 'has [nonetheless] become a whole climate of opinion' seems apt (1996: 10).

\section{Foucault's Self-Critique}

Despite his famous elusiveness Foucault did offer something approximating a personal overview in his revealing interview with the Italian journalist Duccio Trombadori (1991d). He defined three critically important aspects to how he interpreted the meaning of his various experiences. There was, firstly, the idea that 'no continuous and systematic theoretical "background" or rule of method' ... [governed] his work' and that his interpreters would look in vain if they set out to discover it. Secondly, he suggests that 'there is not a book I have written that does not grow, at least in part, out of a direct, personal experience'. For example, the statement that everything he wrote evolved out of his personal experience led Miller to conclude that all Foucault's 'books amount to a kind of involuntary and unnoticed memoir' and that they should be considered in this light (1993b: 33). The third aspect was that he was preoccupied with 'limit-experiences'.

This neologism, as I described earlier, is essential to understanding the 'enigmatic stitching' that unites 'Foucault's death, life and work' (Miller, 1993a: 29). It established 
an orientation to how we might best understand his own assessment of his writing and the purposes that informed it. For example, he argued that it was:

... this de-subjectifying undertaking, the idea of a "limit-experience" that tears the subject from itself, which is the fundamental lesson that I have learned from [Nietzsche, Bataille and Blanchot] ... And no matter how boring and erudite my resulting books have been, this lesson has always allowed me to conceive them as direct experiences to "tear' me from myself, to prevent me from always being the same. (1991d: 31-32)

The intent of all of this was to construct 'an experience of our modernity that might permit us to emerge from it transformed'. How unsettling this might be he described in respect of Madness and Civilization where he stated to Trombadori that it is 'necessary that what it asserts is somehow "true", in terms of historically verifiable truth'. But he confounds our immediate response to the idea that verifiable facts are important for he goes on to argue that, nonetheless, what is essential is not found in a series of historically verifiable proofs; it lies rather in the experience which the book permits us to have' (my italics). He moves our critical consciousness away from reliance on 'facts' historically verifiable proofs - and back into the particularity of our experiences. He did not consider modernity and its fetish for facts as truth, per se, but as an experience of 'truth'. As he continues, 'an experience is neither true nor false: it is always a fiction, something constructed, which exists only after it has been made, not before'.

Within this Foucaultian 'frame' we can only reflect on our experience as it 'has been made', for any a priori interpretive assumptions that we make on the basis of such 'experience' must necessarily be 'fictions'. As he goes on, 'it isn't something that is "true" but it has been a reality'. But it is our reality alone. What he is arguing for is our acceptance that truth can only be determined 'as used within an experience' and not in an interpretation of it. It is this core assumption that informs his research approach (1991d: 34). As Deleuze explains: "Truth, in other words, doesn't imply some method for discovering it but procedures, proceedings, and processes for willing it' (1995: 117).

Foucault says of Discipline and Punish that while "the investigation makes use of "true" documents' his intention is not to 'furnish ... just the evidence of truth but also an experience that might permit an alteration, a transformation, of the relationship we have with ourselves and our cultural universe: in a word with our knowledge'. He called these the 'games of truth and fiction' or 'evidence and fabrication'. He offered an explanation for modernity but presented it in such a way that our experience of his rhetoric did not lead simply an intellectual yes or no. He had a dual expectation to "permit us to see 
clearly what links us to our modernity and at the same time will make it appear modified to us'. It was rather that responding to his critique 'might permit an alteration, a transformation' of our knowledge.

Trombadori, querying Foucault, asked whether he might then best be described as a 'teacher'? His response is very illuminating because it does present further insight into his overall intentions. He uses the reaction to Discipline and Punish to 'answer' Trombadori's question. He rejects the idea that the approaches in his books could be some sort of implied teaching. Precisely because to define his books as instructive, in that sense, implies that they are systematic and could lead 'to a method that could be generalized, a method full of positive directions, of a body of "teachings" for the readers'. What he intends is to issue more of an 'invitation'; they are 'public gestures, for those who may want eventually to do the same thing, or something like it, or, in any case, who intend to slip into this kind of experience'. He stated that 'in a certain sense' Discipline and Punish 'is an historical investigation. But its audience appreciated or detested it not as a historical work'. He thought the strong public response to it arose from an 'immediate' affect on his readers - that it provided an experience in which they might say that the book 'was about them, the world today, or their relations with "contemporaneity"'. He wanted the book to be read as an experience that changes us, that prevents us from being the same, or from having the same kind of relationship with things and with others that we had before reading it".

On the face of it that is an extraordinary and perhaps arrogant claim. However, if the experience of reading his books 'worked' in the way that he intended then perhaps his claim to have established the "transformation of contemporary man ... in relation to his sense of self' made some sense. This transformation represented his understanding of what 'agency' might properly be. It was not an invitation to participate in yet one more normative truth 'claim' but to reflect more deeply on the dominating rationalizations of modernity. Thus each of his books, as he sees them, are best understood as 'an "experience-book" as opposed to a "truth-book" or a "demonstration-book". Unfortunately, very few of his readers and reviewers really understood the nature of this 'invitation'; or if they did, they declined to take it up (1991d: 31-42)! 


\section{Sighting', 'Inciting' or Citing Foucault!}

Megill (1987) has provided a more novel assessment of Foucault's 'place' within historical scholarship by undertaking that most respectable of tasks (being the empirical historian that he is) and charting references to Foucault in the Arts and Humanities Citation Index $(\mathrm{A} \& \mathrm{HCl})$ as well as in the Social Sciences Citation Index (SSCI). Megill reports that in the $\mathrm{A} \& \mathrm{HCl}$ Foucault is the twenty-fourth most heavily cited. This is impressive for an author so recent. He is the eighth-youngest writer to appear on the list; among those younger than he, only Chomsky and Derrida are more cited' (1987: 118-119). Megill considers that this represents the fascination within Arts and Humanities about the nature of language and the topicality of discourse analysis - one of Foucault's prime concerns. However in the SSCl Foucault only rated $60 \%$ of the citations recorded in the $\mathrm{A} \& \mathrm{HCl}$, though Megill notes that this 'understates the difference, for in any given period the SSCl contains about twice as many citations as does the $\mathrm{A} \& \mathrm{HCl}^{\prime}(1987: 120)$.

Megill's conclusion about the respective value of the two indexes is that being cited in the $\mathrm{SSCl}$ has some relationship to the relation of scholarly articles to respective academic disciplines, since that work adds to the research programs of these separate academic disciplines. While in the $\mathrm{A} \& \mathrm{HCl}$ index 'many authors would be highly cited because they present an original and provocative world view' (1987: 121). The SSCI reflected the value of work accomplished 'within' the originating discipline of the writer, while popular citation within the $\mathrm{A} \& \mathrm{HCl}$ was more indicative of the writer's ability to transcend disciplinary boundaries and protocols. The fact that Freud and Marx appear at the top of both indexes is proof, Megill argues, that they are the best examples of writers who can both be 'iconoclasts and producers of disconcerting insights'.

True significance, in terms of these indexes, represents the ability to provide a 'provocative world view' and demonstrate how that iconoclasm is located within a particular discipline. It provided an obvious opportunity for other scholars to replicate, falsify or challenge the ideas not only expressed as a 'world view' but also as representative of an academic discipline. As Megill states: it 'is clear that Foucault provides a worldview. The extent to which his work can contribute to the carrying forward of research programs is less certain' (1987: 121). Megill's research also demonstrated which of Foucault's books were most frequently cited. Discipline and 
Punish was at the top, followed by The History of Sexuality, Madness and Civilization, and The Order of Things. Megill's conclusion is that this ordering in the citation indexes represents Foucault's particular relevance to 'social history - the books on prisons, sexuality, and madness' (1987: 122).

One reason that Foucault provoked such disdain amongst empirical historians was that he 'was simply not an accredited member of the guild' (Megill, 1987: 127; though there is reason to be cautious about Megill's accuracy - see the following footnote). ${ }^{\text {xxxiv }}$ Even more challenging of Foucault's view of history was Said's opinion that it 'is but one discourse among many' (1972: 13). Given that Foucault's 'main aim was to elucidate and undercut present belief and ethical systems' it was inevitable that aims such as these would earn considerable wrath with 'guild historians' (Baert, 1998: 124). Equally, we can readily understand why such disciplinary sentiments (the 'policing function of the closed academic 'shop' of the historian's guild) were not acceptable to Foucault. It was proof, to him, if he needed more, of the restricted nature of 'reason's excuses'. His disdain of intellectuals, as a presumed elite caste, was revealed in his famous ironic aside in The Masked Philosopher that he understood 'people who teach, people who paint, and people of whom I have never really understood what they do. But intellectuals, never' (1988d: 324).

\section{The 'Hanged Theoretician': Skinning Foucault Alive (an écorché vif)}

Megill's 'difficulties' with Foucault are not idiosyncratic: they are widespread - examples such as this are found in much of the critical assessment of Foucault and more specific examples will be presented later in this chapter. He was such an 'easy target' for the smart, sharp-edged quip. That the language and the sentiments of such personal vilifications 'found its mark', and hurt him, is clear. It is an example of his peculiar sensitivity in that someone as famous as he was had not developed some immunity to such negativity. Indeed we might wonder why he did not embrace such 'fame' - the lot many public intellectuals would envy! However we interpret this he did write with so much obvious personal feeling:

I have an unfortunate habit. When people speak about this or that, I try to imagine what the result would be if translated into reality. When they "criticize" someone, when they "denounce" his ideas, when they "condemn" what he writes, I imagine them in an ideal situation in which they would have complete power over him. I take the words they use demolish, destroy, reduce to silence, bury - and see what the effect would be if it were taken literally. And I catch a glimpse of the radiant city in which the intellectual would be 
in prison or, if he were also a theoretician, hanged, of course. (1988d: 324 , emphasis in the original)

Megill's ambivalent commentary about Foucault as the 'non-historical historian' who was not really acceptable to the guild of historians demonstrates that common inability of scholars to write about him from anywhere other than the relative epistemologies dictated by the canons of their respective disciplines. He certainly had to deal with an amazing public reaction to his ideas as he alluded in the above quote - he was the incipiently the 'hanged theoretician'! As a result, much of the commentary is polarized or ambivalent. That Foucault 'straddled' so many different intellectual fields is one reason for how vainly the respective disciplinary 'fishermen' sought their prey! As Megill concludes:

Foucault is solitary, he has nonetheless become part of a collective machinery of research, reflection and argument. Though he is not of the discipline, he is important to it, partly because he has called attention to hitherto neglected fields of research, but mostly because he fosters a self-reflection that is needed to counter the sclerosis, the self-satisfaction, the smugness that constantly threaten. (1987: 134)

Equally outrageous, as the guild mentality of the scholarship Megill describes, is how easily reviewers apply ad hominem language. This was something that astonished and surprised Foucault, even though Bernauer thought he ought not to have been (1986: 19). What provoked such explicit disdain? Is it a solely the reaction of an academic protecting his 'patch'? Are the reviewers of Foucault's complex arguments inevitably reduced to one-liners? And if so, what might that reflexively demonstrate about our respective criticisms? Is Seigel's suggestion correct (1990) that Foucault's overall work cannot be fully assessed apart from a detailed awareness that his homosexuality 'appears' in a coded form right throughout his writings? Did his sexual orientation serve as a constant counterpoint to the academic criticisms of his books (c.f., Bersani, 1995; Cohen, 1988; Halperin, 1995, 1998; Miller, 1993a; Smart, 1991)?

These questions are not easily resolved but considering them in respect of the place of Foucaultian scholarship sets the context of the debate, since Foucault continues to have a significant place in our contemporary thinking in quite widely diverse fields. For example, he was a theoretician who was 'of overriding interest to literary critics, to novelists, to psychologists, medical men, biologists, and linguists (and in general to all those professionals who are interested in the past and contemporary states of their disciplines)' (Said, 1972: 1). Said's 'list' has echoes of that famous list cited by Foucault 
in The Order of Things which included 'the embalmed, sirens, sucking pigs, stray dogs, a fine camel hair brush'. These lists of apparently disparate 'things' or 'ideas' are strung together by Foucault not to obfuscate in order to play elusive word games but to unsettle the patterns of particular academic discourses. He demonstrated how this Chinese taxonomy was quixotic, different and strange but yet perfectly understandable within its self-referential frame. It was a set of 'bewildering discontinuities' often similarly seen as intrinsic to Foucault's own methodology (Baert, 1998: 115).

\section{'Solitary Explorer, Opening Up Silent Seas': Assessing Foucault's Career xxxv}

One of the initial conventions in Foucaultian scholarship has been to suggest a marked difference between the earlier and the later Foucault (Gutting, 1994: 24; c.f., Gane, 1986; Philp, 1985; Smart, 1985). However, this is weakened by the various attempts to cite his major works within some overall schema (c.f., Seigel, 1990: 275; Major-Poetzl, 1990; Miller, 1993b). Foucault even provided one of his own, and so heightened the debate about the continuity of his ideas and not the 'rupture' (1984i: 336-338). Reflecting back on the writing of Madness and Civilization he stated that he had three intentions. The first was to analyze the genesis of how the "formation of a domain of recognitions ... [constituted] themselves as specific knowledge of "mental illness"'. The second was to consider the 'organization of a normative system built on a whole technical, administrative, juridical, and medical apparatus whose purpose was to isolate and take custody of the insane'. The third was to evaluate all of this emergent 'disciplinary' activity and its relationship 'to oneself and to others as possible subjects of madness' (1984i: 336).

We can now align Seigel's, Major-Poetzl's and Miller's schemas together with Foucault's 'three axes' which he discussed in the preface to The History of Sexuality, Volume 2; namely, 'modes of inquiry', 'dividing practices' and 'the way a human being turns him or herself into a subject (1984i). ${ }^{\text {xxvi }}$ Another way to consider the first axis is to regard it as the study of the transformation of knowledge (the core of his archaeological work). The second axis reflects his discussion of the relationship of knowledge to the formation and function of normative discursive rules (i.e. his genealogical studies). The third axis reflects his later thinking about the relation of knowledge to the self - where there is a steady transformation from genealogical work to the 'care for the self'. While expressed differently the sense of these threefold axes is the same. We can locate his major 
publications in relation to this threefold schema. Under the first axis Foucault listed Madness and Civilization: A History of Insanity in the Age of Reason, Birth of the Clinic: An archaeology of Medical Perception, The Order of Things: An Archaeology of the Human Sciences, The Archaeology of Knowledge. Under the second axis Foucault listed Discipline and Punish: The Birth of the Prison, 1977, and under the third the three volumes of The History of Sexuality.

This schema obviously establishes some sense of a pattern to the evolution of his ideas, but not a necessary progression. For example, Deleuze suggested that 'Foucault's thought is a thought that didn't evolve but went from one crisis to another' (1995: 104). It emphasizes the differences between his archaeological phase and a shift to genealogical phase. It suggests, as Gutting argues, that Foucault's early books might well have been 'volcanic subtexts of mythological struggles' but that this initial 'heat' and fervour disappears in the later Foucault and is transmuted into 'the cool exploration of aesthetic forms of human existence' (1994: 24). Although we can recognize 'strong threads of consistency' it is also true that Foucault 'repeatedly went back over his earlier works and reworked his ideas - much to the delight of his many followers, and to the confusion and irritation of his equally numerous critics' (Philp, 1985: 68). It is obvious that Foucault's emphasis changed. He said 'I'm perfectly aware of having continuously made shifts both in the things that have interested me and in what I have already thought' (1991d: 26).

Baert recently argued that 'new light can be thrown on both Foucault's archaeology and his genealogy: both are directed towards a self-referential form of knowledge, and as such the two periods are shown to have more in common than conventionally assumed' (1998: 111). We are, with some time and distance, more able to see Foucault 'whole', to seek out some 'stable features behind his projected facelessness and a definable pattern underneath his labyrinthine movements' (Seigel, 1990: 274; c.f., Lloyd, 1986; O'Hara, 1991b). Though that has never been an easy task and what we mean by 'whole' must still be made explicit! Which is not, as Seigel urges, to assume that by so doing we fall into the trap of 'doing the work' of the police or bureaucrats who would inquire whether our 'papers are in order' (Foucault, 1972: 17). He always defined himself as 'more an experimenter than a theorist; I don't develop deductive systems to apply uniformly in different fields of research. When I write, I do it above all to change 
myself and not to think the same thing as before' (1991d: 27). It is obviously hard to draw overall patterns out of the work of such an unrelievedly 'personal' experimenter! What we have are his explicitly personal reflections and his clear statement that 'I don't construct a general method of definitive value for myself or others. At most, its character is instrumental and visionary or dream-like' (1991d: 29).

Seigel, similarly to Baert, has suggested that irrespective of Foucault's protestations there was a 'strong line of continuity' in his career despite the heralded, and much discussed, discontinuities in the apparent shift from archaeology to genealogy to the techniques of the self. ${ }^{\text {xxxvii }}$ As he argues, the 'aspiration to theorize a radical subjective freedom that inspired his writings of 1954 never wholly disappeared from his work' (1990: 297). The 'arc marking the entire trajectory of Foucault's thought' inscribed a journey from 'epistemology through strategy to ontology' (Dean, 1995b: 21). O'Hara also sees Foucault's career 'as one comprehensive critical meditation on the subject of knowledge as the dialectically related masks of modern reason' (1991b: 89). It is this career-long preoccupation with subjectification and 'limit-experience' that generated the counter reaction that Foucault had no expressed agency - no way to contextualize his actual agonistic assertions about freedom and truth (c.f., Habermas, 1986a, 1986b, 1987; Fraser, 1989b). Seigel suggests that it 'was the inner force of these contradictions' that prompted the emphasis on 'care for the self' and how this ethic required 'a "practice of liberty" that once more gave recognition to an autonomous subject' (1990: 298). There was a 'return' to that initial preoccupation with the possibility of truth and freedom and thus a strong challenge to the assumption that he had no real political fight.

\section{Periodization, Accountability and Process}

Trying to compress Foucault into a tight periodization of his ideas, and demand that he should undertake a historical exegesis about the alterations in his thinking and the changes in methodology - from archaeology to genealogy to techniques of the self - will never elicit or illuminate the real or essential Foucault. It certainly bears no relation to his expressed purpose in writing his books. Criticizing him for such failures is vapid for this was never his articulated intention and it fails too at the fundamental level for it demonstrates a complete lack of awareness of the subtlety of his arguments involved in his analysis of power/knowledge. Seeking 'the 'true' Foucault, even adequate exposition 
is illusory' (Gane, 1986: 121). Foucault would not have us believe that there was much 'mileage' in progress generally, and specifically trying to understand and chart the shifts in his ideas as some form of internal and private progress is equally illusory. His concept of genealogy presumed that we cannot rely on any sense of continuity and that all notions of progress are flawed. As he said in Discipline and Punish, 'Humanity does not gradually progress from combat to combat until it arrives at universal reciprocity, where the rule of law finally replaces warfare; humanity installs each of its violences in a system of rules and thus proceeds from domination to domination' (1979a: 151).

That phrase - 'limit-experience' - has occasioned much debate about the implication of this idea in relation to his homosexuality as well as being a commentary on the subtlety of his research methodology. It was seen to imply more than just his expression of how his books ought properly to be 'read' (c.f., Halperin, 1995, 1998; Miller, 1993a; Seigel, 1990). Foucault may well have been wrestling with Nietzsche's comment that 'the riddle which man must solve' - [was] the riddle of his own singular being and that this was what he meant by making of the self an ethos - the technology of the self (1993a: 245)? For example, as Said argues, one:

... reason ... that Foucault seems to give artists, visionaries, madmen and deviants (Hölderlin, Sade, Nietzsche, Beckett) so important a place in his historical and theoretical studies is that they, more than the average user of discourse, exaggerate and make plain in their solitude and alienation the exteriority of discursive practice by outdoing discourse. What is heroic about such men is, paradoxically, their willingness to accept the terrifying freedom that comes from hyper-individuality. (1974:36)

Seeing Foucault's work as more of a whole, and more explicitly related to him personally, does provide a different perspective on his disdain of traditional intellectuals. The traditional conception of the intellectual 'assumes that the intellectual is a messianic figure, who preaches from above, and who incites political action in the name of truth' (Baert, 1998: 123). Foucault would have none of this, as the notion of a dispassionate observing distance was anathema to him, especially to his ideas about 'limit-experience'. For he constantly argued that we should examine the 'practices' of our respective knowledges and not presume to rely on the status of the speaker or the author. As he wryly declared, demonstrating perhaps that Foucault was a 'terrible joker', as Deleuze argued (1995):

'What can the ethics of an intellectual be - I claim this title of intellectual, though at the present time, it seems to make certain people sick - if not this: to make oneself permanently capable of detaching oneself from oneself. (1988g: 263, 1977a) 


\section{The Role of the Author}

As Said concluded, Foucault's oeuvre has a unity all its own, and indeed a beginning all its own in the perceptions he has of history and language. As author, then, he dramatizes an oscillation between writing as discourse (the author is a function of the discourse in this case, of interpretation) and writing against discourse (1974: 37). This is much traversed ground within a social policy perspective and a full exposition of this is beyond the scope of this thesis (c.f., Archambault, 1985; Burke, 1992; Foucault, 1977a, 1979; Hollier, 1985; Nehamas, 1986, 1987, 1993, 1998; Said, 1972, 1973; Silverman, 1993; Stenson and Watt, 1999). However, while Foucault's 'self-revision is theoretically consistent with one of the principal themes of his historical research, the disappearance in contemporary knowledge of man's role as central subject, author and actor', it was not 'practically consistent', as Said argued. Despite his protestations he was 'the unusually impressive author of his work ... An anonymous writer he clearly is not' (Said, 1974: 28). Hacking similarly argued that Foucault's 'obsession with words was too fragile to stand. Foucault had to return to the material conditions under which the words were spoken' (1981: 34).

While there is a common perception that Foucault was intellectually reclusive there are 'flashes' of his self, as friends found him, that present a different picture. Nehamas suggests that for Foucault any contemporary:

... critical practice is centrally characterized by an effort to show that the texts of an author are continuous and not inconsistent, internally or with one another. This practice he believes is motivated by the hope that in this manner we may capture the unique mental state, meaning, or message, which we assume all authored texts to express and communicate. But this vain hope directs us to the wrong enterprise. (1987: 271)

Foucault's theories were 'not intended to be used as a kind of pass-key for unlocking texts' (Said, 1972: 2). What he intended was to work within the complex themes of anonymity, hence his attempt to deny the author per se any centrality. Foucault suggested that: 'whenever and however the author emerged in modern times, it is not so much a person as a figure, or a function, or a role' (1987: 270).

He argued that if we accord authorship and writing a 'primal status' we risk retranslating what is contingent and particular into 'transcendental terms' that falsely accords our interpretations primacy over experience. Relying on descriptive forms of interpretation, he suggested, inscribed certain texts with a quasi-theological sacred character, and so 
the 'critical affirmation of its creative character' is located in the past and has little to do with modernity (1998: 208). His attack on the author 'is nothing less than an attack on this descriptive and interpretive conception of criticism as a whole' (Nehamas, 1987: 272 , my italics). He queried the assumption that the inevitable historical transience of writing means that it must be subject to interpretation because of the 'religious principle of the hidden meaning'. This was the assumption that something that is now lost, because of death, can still be recovered through superior interpretation of what the original author 'really' meant. He rejected the idea that commentary can elicit 'implicit significations, silent determinations, and obscured contents'.

Edward Said sets out an imaginative perspective on what Foucault aimed at in his arguments about authorship and the possibility of interpretative critique. He thought that Foucault described his 'attitude to the past is that of a spectator watching an exhibition of many events' and that what we watch with Foucault 'is an exciting exhibition - and I do not by any means intend this to be a pejorative description' (1972: 5). For Said, that implies that 'there must first be a re-ordering of documents so that they shed their inertness and become a sort of measurable activity; this re-ordering, or re-orienting of texts from the past takes a maximum of intellectual and scholarly energy' (1972: 5). It is an interesting notion that the reviews that follow should equally 'shed their inertness' for there is the sense in so many of the comments about Foucault that they are striving to have their ideas 'written in stone'. Very rarely is there a sense of developmental 'engagement' with Foucault's ideas.

\section{Different 'Cages of Ideas': What Manner of Review?}

Collectively, these reviews demonstrate a critical oscillation ranging from clever and insightful awareness of Foucault and his intellectual purposes to florid and totally reflexive excesses where different reviewer's fashion their interpretations with no subtle awareness of him at all. So many think that they had cleverly 'captured' Foucault or elegantly skewered him in some succinct riposte! While there are some that adopt a more balanced tone in their assessments others are explicitly polarized. Many reject Foucault's querying the legitimacy of authorship - and would agree more with Nehamas that their respective critiques did give 'concrete expression of the idea that the purpose of criticism is to provide definitive interpretations of texts, revelations of their meaning' (1987: 271). And in that sense they avoid the critical reflection on modernity - the 
invitation to reflective engagement that Foucault's work offers - which deconstructs the imperial 'presence' or magisterial 'command' of the Author.

I intend to let these reviews 'speak for themselves', being one more point of reference to the 'problem' of 'who or what, is Michel Foucault' (Faubion, 1998: xiii). That so many of them write from 'within' the epistemological sets of their respective disciplines is an obvious but nonetheless fascinating aspect. Perhaps none more so than the following comments from a review of Madness and Civilization:

A reading of Foucault offers a radical challenge to much of the traditional sociology of health and illness ... problems remain and the apparent precipices of relativism and regression, of solipsism and language lie ahead. Perhaps his influence, limited though it is, will not long survive his death, but certainly within a brief period of twenty years, he has turned the human sciences inside out.

Foucault is difficult to place (and difficult to summarise!), interdisciplinary, crossdisciplinary, denying a lineage. But, like every other body, it was inevitably subject to the very analysis it had sought to lay bare. Medicine pronounced the cause of his death as a 'rare brain infection': a fairly non-specific diagnosis for what seems to have been a somewhat mysterious death. It is perhaps the ultimate irony that the author of Madness and Civilization which radicalised our view of insanity and of Birth of the Clinic which revealed the hollow triumph of a reductionist model of illness should have died from a rare inflammation of the cerebral tissues. For only a passing moment the medicine of pathological anatomy had managed to grasp in death the life of a very fevered brain. (Armstrong, 1985: 116)

There is much in this quotation that reveals the approach commonly found in many of the reviews that sought to encompass, explain, define, and reveal 'Foucault', or, alternatively to demolish, destroy, reduce to silence and bury to use Foucault's own descriptive list (1988d: 324).

The way this reviewer shifts his ground from some assessment of Foucault's intellectual significance towards an implicit personal criticism that reflects the safe or at least the known grounds and epistemology of his own medical discipline is interesting, to say the least. For example, he states that medicine 'grasps in death' that which had eluded previous assessment; the 'body' of Foucault 'was inevitably subject to the very analysis it had sought to lay bare'! The 'body' is both Foucault's corporeality and also implies his overall oeuvre. Is this, indeed, an example of the 'loquacious [medical] gaze', which Foucault describes in The Birth of the Clinic? We might politely demur that analysis of a 'body' of knowledge is not quite the same as an analysis of a 'body' riddled with AIDS! There is no real sense that the reviewer really wants to 'grasp in life': its as if the ultimate 
discipline of death is the best critic and as a representative of the medical profession who best to comment on that?

It is clever wordplay for Armstrong to end with an apparently 'medical' assessment about Foucault's 'very fevered brain'. But it also reveals the internal critical bias - the irresolution and contingency of ideas that Foucault captured so well - for Armstrong clearly associates the phrase 'fevered brain' as a referent to Foucault's intellectual work as well. This review, quite powerfully, expresses one common feature in the critical oscillation about Foucault. It did not just assess his ideas on some binary axis of good/bad, relevant/irrelevant. It is yet one more example of how easily the language of critique, arising out of the 'guild mentality' of a particular professional bias, shifts to an ad hominem position that is presumed to be the 'final' 'definitive' answer to 'who or what is Foucault'. Foucault had imaginatively captured his sense of what this critique meant; 'a meaning has taken shape that hangs over us, leading us forward in our blindness, but awaiting in the darkness for us to attain awareness before emerging into the light of day and speaking' (1973: xvi). It is ironic that he should have argued so passionately that we apply his genealogical analysis to the patient discovery of the minute details of 'forgotten lives' but that so often his reviewers and interpreters would not accord him the same intellectual respect!

\section{The Reviews: Patterns and Processes.}

Foucault provoked widely polarized opinions, oscillating from genuine delight at his originality (Laing, 1967: 843 ) to even recommending that no one actually read The History of Sexuality because it is so bad and dangerous (Robinson, 1978: 29). Nehamas observed that Foucault's 'controversial views and his unconventional life have provoked admiration and disdain, adulation and disgust'. As he continues, he 'was that extremely rare creature, a genuine intellectual who was an international celebrity' (1993: 27). In order to provide a sense of this oscillation it is important to indicate the full range responses both for and against Foucault. There are few that find a balance within that continuum but they are separately useful. He had little to fear, it seems, from that injunction in the Book of Revelations 'because you were nether hot nor cold I will spit you out of my mouth'. He is certainly very 'hot' for some and clearly 'cold' for others. It is as if this very notoriety or celebrity is a separate 'target' that the reviewers hold in 
their sights as they assess a particular book. This holds for both positive and negative opinions.

I have attempted to discover as many of the individual reviews of his books as possible and distil from them something of that 'collective' but clearly singular and idiosyncratic response to Foucault. While many reviewers tried to set their opinions of his books within their appreciation of a wider intellectual context for Foucault's ideas Turkle, reviewing The History of Sexuality, Volume 1, set out one of the clearest arguments for why Foucault has prompted such vilification in certain of his reviewer's minds:

It is interesting to reflect on the violence of the reactions to Foucault and his colleagues. What makes them so infuriating? Critics ... make much of their opacity and their failure to cite evidence. I myself find that I can come to terms with the French task for putting poetry in science by understanding its function. In order to put into question assumptions deeply imbedded in our ordinary language, one has to use language in extraordinary ways.

I believe that there is another and perhaps more fundamental element in Foucault's capacity to infuriate. It is very hard to cope with theories which include an explanation for why we might reject them, it is as though in rejecting them we prove their truth. The classic example of such a closed system is psychoanalysis, but we find the same circular pattern in Foucault's work. He claims that he speaks truths about power which are unacceptable in much the same way Freud believed that his theory of infantile sexuality was unacceptable, an inassimilable element which made psychoanalysis a subversive doctrine. Times have changed ... But if there is any doctrine which threatens us today as Freud's theory of sexuality threatened the Victorians, it must surely lie in the direction of questioning man's autonomy. (1979: 94)

I have set out the extracts from these reviews in a format that highlights the various reviewers' comments. They are grouped into 'The Doubters' initially, then 'Those Who Praise' and finally 'The Fence Sitters'. I have not set out a detailed discussion of the content of these reviews such, but rather of their expressed attitudes to Foucault. They do speak for themselves. These extracts are things taken from various reviewers' 'tool boxes'. They are ideas that the 'merchant selling instruments' or the 'recipe-maker', the cartographer perhaps, the one who 'maps out power relations' or even the one who 'draws diagrams' might well have taken some delight in, but equally well may have not (Bersani, 1977: 6)! It is framed as 'ideas in progress' within the same sense of 'invitation' that Foucault intended when he defined all his books as 'little toolboxes'. He saw such use as being essential to his view of knowledge so that if we ' want to open them, to use a particular sentence, a particular idea, a particular analysis ... well, so much the better' (Mottier, 1995: 27). 


\section{Madness and Civilization: A History of Insanity in the Age of Reason [1965]}

\section{The Doubters:}

- 'Foucault is a French psychopathologist and litterateur. Absolutely essential for any collection in abnormal psychology' (Howard, 1965-66: 735).

- 'The book ends with a satanistic encomium of madness ... [Foucault's 'language of unreason'] is the idea of an endless delirious monologue, which neither the man of reason nor the madman himself can understand' (Scruton, 1971: 513).

- "Madness and Civilization" is not only difficult, but often irritating reading. When he is dealing with the classical, pre-scientific view of natural phenomena, Foucault is much too detailed for my taste; when he is dealing with the subtly inflected moral issues from which he weaves his argument he is sometimes too abstract for my comprehension' (Friedenberg, 1965: 6).

- No one should try to dismiss the argument simply because the Marxist-Existentialist world of intellectual Paris makes a habit of turning all conventional assumptions upside down or because Foucault himself is too fond of barely meaningful aphorisms' (Leitch, 1967: 753).

- 'More serious is Foucault's willful opacity; again and again he clothes his thought in formulations in which dim echoes take the place of precision, and pretentiousness borrows the shape of profundity' (Gay, 1965: 94).

\section{Those Who Praise:}

- 'Madness and Civilization is truly an important book, one of those rare events in the history of social sciences - a book that merits not only reading but rereading' (Rieff, 1967: 258).

- ' $\ldots$ we can surmise that if Foucault continues to survive the torrent of his intellect he will be one of the writers to whom we shall in our life time continue to turn with a somewhat terrified delight, to be instructed when we are not too dazzled' (Laing, 1967: 843).

- 'Any attempt to summarize the transformations described in this book would give little idea of the richness of its analyses and classifications, and of the sociological insights which make it one of the best studies in the historical sociology of knowledge' (Peters, 1971: 637).

- 'The real achievement of this book (and without being rhapsodic, I am perfectly well aware of its shortcomings) - is its invention' (Rousseau, 1970: 95).

- 'Foucault writes this little chapter of exclusion with poetic skill, ascribing significance to the symbolism of the navigational journey, the water and the polarity of the confinement and the freedom of movement. Foucault 'makes no pitch for any modern dialectics as an approach to mental illness. He never mentions unconscious vs. conscious, id vs. ego, a primary process or a secondary process. This is admirable, scholarly and stubborn (Reider, 1965: 22-23).

- It is brilliant, a landmark in social thought that is both the first truly original treatise on mental illness since Freud and the first successful attempt to actually apply the phenomenal method, rather than simply commending, promoting or elaborating it. 
Foucault's account of madness strives for the deepest level of human understanding. Consequently he neither denies the pathetic or desperate reality of madness, something which is au courant in Sociology, nor does he reduce the phenomena to a set of symptoms, draining it of significant human content, something which has been endemic in the prevalent psychiatric rendition. Instead, he grapples with the intricate processes by which the human meaning of madness has been assembled and then obscured or suppressed by historical persons in different epochs. The result is a work in which the gulf between humanism and science miraculously disappears' (Matza, 1966: 551).

\section{The Fence Sitters:}

- If 'one does not take the muddy metaphysics too seriously, there is a good deal of solid substance in this book' (Rosen, 1967: 211).

- 'There is no greater damnation possible of the pseudo-scientific psychiatries of the present than to grant a tolerant understanding to these psychiatries of the past. There absurdities seem so comprehensive ... It is essentially a discursive (and ultra-literary) account of the stages in the evolution of Western mythology about 'science' (Peters, 1971: 636).

\section{Birth of the Clinic: An Archaeology of Medical Perception [1973]}

\section{The Doubters:}

- 'His following must consist largely of masochists, and those who can admire while they do not understand, for Foucault, though ultimately intelligible, is flamboyantly difficult: more interested in turning a phrase or framing a paradox than in making himself understood ... if Sartre looked bloodless before, he looks effusively Mediterranean now' (Howe, 1974: 117).

- Foucault 'envelops his thought in the verbal fog that is one of the by-products of the otherwise fruitful marriage of Freud and German philosophy. In translation, he emerges as the archetypal foreigner - barely comprehensible, vaguely suspicious but avoided' (Zeldin, 1973: 861).

\section{Those Who Praise:}

- 'By this time it should be unnecessary to add that Foucault's work is indispensable for cultural historians, amply rewarding the effort required to understand it' (Lasch, 1974: 6).

- In tracing the birth of modern clinical practice as a creature of the Enlightenment and the Revolution, Foucault has performed a marvellous task of cultural analysis' (Aronson, 1974: 474).

- 'The depth of Foucault's vision, encased in often esoteric but always stimulating prose makes the Birth of the Clinic an important source of new insights' (Kupers, 1975: 238).

- ' $\ldots$ the book is fascinating and unlike anything else written on the subject' (SheridanSmith, 1974-5: 114).

- When he describes the break which separates the new clinical science from all preceding scientific discourse, Foucault is perhaps depicting in emblematic form his own undertaking, his own break with traditional intellectual history. Not the least of the book's attractions is that it repeatedly allows us to glimpse the face, the personal and distinctive features of a philosopher-historian whose educated aim is nevertheless to get rid of the 
subject and subjectivity, to disappear in his own discourse (perhaps to disappear from his discourse) and to leave the way open for a formulation of the anonymous rules which govern human knowledge and behavior' (Starobinski, 1976: 22).

\section{The Fence Sitter:}

- 'But it is not on its historical accuracy that the merits of this book, or any other book by Foucault, depend, but rather on its clustering of a set of individually brilliant and collectively original insights, drawn from a domain that as yet has not found a settled form for historical purposes' (Caws, 1973: 30).

\section{The Order of Things: An Archaeology of the Human Sciences [1970]}

\section{The Doubters:}

- 'Anyone who can turn Foucault's prose into something resembling English deserves a medal ... [This kind of French writing being] 'over-argued, over-sophisticated, affected, pretentious and given to esoteric word games' (Bossy, 1971: 775).

- Is this kind of thing to be taken seriously or does it belong ... to "the murmur of the ontological continuum"? Is anything being said here, which can be grasped and verified in any rational way? ... a thinner, more scrupulous book is struggling to emerge from this oracular corpus ... Yet even where its sibylline loftiness is damaging, one is left with a sense of real and original force' (Steiner, 1971: 28-31).

- 'Even more parochial is Michel Foucault's insistence on finding French antecedents for British ideas' (Moore, 1971: 490).

\section{Those Who Praise:}

- '... there was nothing - or almost nothing - freakish or parochial about Foucault after all; that he is carrying out, in the noblest way, the promiscuous aim of true culture, which is, as Matthew Arnold used to say, to do away with classes, or at least as we would now append, with classifications. That when Foucault says that for us literature has become "a silent, cautious disposition of the word upon the whiteness of a piece of paper, where it can possess neither sound or interlocutor, where it has nothing to say but itself, nothing to do but shine in the brightness of its being", he is speaking with the same eloquence we may hear in Northrop Frye ("the sense of an identity in literary experience which is the objective counterpart to the reader's own identity")' (Howard, 1971: 22).

- The realization that all historical evidence is contemporary (just as fossils, mummies, Roman villas exist now, not in the past of which they are now the remains), while obvious enough when it is pointed out, puts things in a genuinely new light' (Caws, 1971: 32).

\section{The Fence Sitters:}

- 'Having worked hard for his erudition, his insights, his subtle deviations from more ordinary ways of thinking, Foucault sees no reason why his reader should reap the results without sharing the toil. If you want to think in a way that affects more than a selfenclosed game of thought, Foucault gives only tantalizing hints of any changes of outlook, feeling and action that his cultural analysis might eventually suggest' (Harding, 1971: 22). 
- If Foucault's writing is "attuned to the style of the universe", it is the universe of St. Germain des Près ... Foucault's 'subject is nothing less than the making of the modern mind' (Huppert, 1974: 191).

\section{The Archaeology of Knowledge (and The Discourse on Language)}

\section{The Doubters:}

- 'The peculiar, and I think the crucial, problem of The Archaeology of Knowledge is its attempt to define effectiveness without theory, that is, to regard practice not as a cause of effectiveness but as the main part of it' (Said, 1974: 34).

- 'Foucault has always been a repetitive as well as obscure writer, prone to a kind of selfintoxication that can, at times, produce prose resembling erudite poetry. The new book has moments, but it is for the most part an elaborate set of methodological doodles in the margin of the old, and one easily grows impatient. An increasing number of people seem to want to know what Michel Foucault is saying, even though the news has gotten around that he makes it very hard to find out. The reviewer's first message to these brave spirits must be a negative one: do not begin here. Defenders of French opacity would reply that we ancient champions of lucidity are craftily concealing a desire to "recuperate" a body of disquietingly-revolutionary body of thought - to domesticate it, make it fit our own obsolete intellectual procedures. Just as we are troubled by what seem wanton neologisms and gratuitous syntactical inventions ... so we are troubled by what seems a xenophobic narrowness of reference ... I no more think he should be ignored than that he should be imitated' (Kermode, 1973: 37).

- 'By Foucault's own admission his method is more an exploratory series of questions and reflections that a finished theory; its usefulness lies in opening up a rather chaotic domain and in its implicit challenge to the neat but abstract categories of the history of the economy of ideas. This usefulness, however, is seriously damaged by a kind of conspiracy of unreadability between author and translator... All this is a great shame. Good ideas ought not to be encumbered with bad prose; readers ought not to have to endure such linguistic torture to get at them' (Caws, 1972: 6).

\section{One Who Praises:}

- 'Foucault is like a man who runs across rooftops, never descending into the houses, never going straight, always really moving from side to side. This perhaps silly picture begins to get at the combination of realism, freedom and discipline with which he negotiates the discontinuous order of knowledge ...The coherence of Foucault's work, despite its visions and revisions, is that he has always returned to the past in order to release from their silence those utterances blanketed by discourse. The Archaeology of Knowledge constructs, with a terminology that often threatens to overcome the matter with which it purports to deal. The skeleton of discourse, archive and statement, whose ethic is hidden in the exteriority of practice' (Said, 1974: 35-36).

\section{The Fence Sitter:}

- 'Foucault's strategies for historical analysis are deeply rooted in a rejection of traditional approaches to the history of thought where the analysis of thought is allegorical in relation to the discourse that it employs ... Archaeology is a radical interrogation of transcendental thought, a questioning of humanistic ideologies, and a reversal of the order of anthropological thought which focuses its questions on man's being. Foucault 
refuses to refer discourse to a subjectivity, an original project, a fundamental teleology' (Leland, 1975: 226).

\section{Discipline and Punish: The Birth of the Prison [1978]}

\section{The Doubters:}

- 'Michel Foucault has become widely known as both a historian of malevolent ideas and a critic of the punitive institutions which most fully express them ...'Its one of the consequences of Foucault's labyrinthine style and the intellectual self-indulgence which it effectively protects, that he gives no attention to the dissimilarities between "What matter to the speaker who's speaking?" and "what matter to the audience who's speaking?"' (Brown, 1978: 658).

- 'Part of the intellectual dazzle of Foucault's book depends on his implying that a bold underlying concept unites his variety of ideas and multiplicity of historical materials; but on closer examination some of these seem to be an assemblage, rather than facets of a complex unity' (Harding, 1977: 803).

\section{Those Who Praise:}

- 'Foucault should not be read as rejecting macro frameworks in preference for micro frameworks, but rather of insisting that the same voice not attempt to cover all registers. His works can certainly be stretched into a kind of global social theory, but with results that seem surprisingly thin ... almost all of Foucault's work situates itself at the level of particular institutions and it is here that his insights are most effective' (Simon, 1996: 319).

- 'Foucault brings under question the criteria by which we establish what is "proper" and what is not. It is a remarkable achievement, significant especially for intellectual history, and Surveilleur et Punir is an important addition to his growing corpus' (White, 1977: 606).

- "Of such "historians" (a description which does not really cover his method) Foucault is the most dazzlingly creative' (Sheridan, 1978-9: 471).

- 'Foucault with his extraordinary subtlety, his ironic trendiness will not be the last to catch the wind' (Kaplan, 1978: 86).

- Whatever the disagreements, "Discipline and Punish" is that rare kind of book whose methods and conclusions must be reckoned with by humanists, social scientists and political activists' (Rothman, 1978: 26).

- 'Foucault's "histories" are filled with sensuous images, bizarre events, dark ironies, and always the drama of a mind interrogating its own origin. Furthermore, Foucault can write with severe, almost epigrammatic, power' (Di Piero, 1978: 314).

\section{The Fence Sitters:}

- 'He regards modern penology as a means by which inmates become servile in the name of medical, psychiatric, and social enlightenment' (Coles, 1979: 97).

- 'By traditional (or rather currently conventional) standards of scholarship the book is a scandal, lacking in "original research" and making only the merest gesture towards 
modern scholarship in the field of penology ...Foucault brings under question the criteria by which we establish what is "proper" and what is not. It is a remarkable achievement, significant especially for intellectual history, and Surveilleur et Punir is an important addition to his growing corpus' (White, 1977: 605-606).

- 'Foucault 'must be given much of the credit for the painful reassessment of the relations between liberty and the Communist revolution which is currently being expressed by the "new Philosophers" ... There are armies of specialists today in the techniques of observation and normalization - to begin with, all the boondogglers in the Department of Health, Education and Welfare' (Kaplan, 1978: 83-85).

- 'He opposes the humanist position that, once we gain power, we cease to know - it makes us blind - and that only those who keep their distance from power, who are in no way implicate in tyranny, can attain the truth' (Cohen, 1978: 566).

- 'One finishes Discipline and Punish burdened with new insights and old despair: the problems are as serious as one thought, but the reasons far more complex, the solutions far more distant' (Jackson, 1978: 251).

- Whether they be images of madness, theories of pedagogy, definitions of sexuality, medical routines, literary styles, research methods, views of language, or procedures for the organization of work, the conceptual systems within which an age is immured define its pattern of dominations' (Geertz, 1978: 3).

- 'In a review of Discipline and Punish Deleuze called Foucault a cartographer; one might say that Foucauldian analyses are more like cartography than hermeneutics' (Cousins and Hussain, 1986: 178).

\section{The History of Sexuality, Volume 1: An Introduction [1978] (including The Use of pleasure: Volume 2 of The History of Sexuality, and The Care of the Self: Volume 3 of The History of Sexuality)}

\section{The Doubters:}

- 'Foucault's theory is less history than a fable ... [it is] 'grim' and 'sinister ... Here we have a new and nasty version of orality: not sex in the head, which used to be the intellectual's ailment, but sex sur la langue ... Recoiling from rude nature, the French want to make sex, like eating, an art - which means making it a frigidly rigid science ... Foucault himself is not only the historian of scienta sexualis but also a practitioner. His structuralist pseudo-science is an agent of the induced confession, the extorted discourse. He demands that everything be articulated, and provides a glossary of clinical neologisms for the purpose. His concern is not the classification of error and the assignment of punishments, like the medieval father-confessor: it is, even more mortifyingly, the reduction of sex into a vocabulary, sin to syntax. 'Foucault has locked himself up within his own structure. In his linguistic prison, all sex becomes a solitary vice, an end-game played not with bodies but with words. Foucault's method inflicts a psychological torture by denying us our right to remain silent' (Conrad, 1979: 452).

- 'Foucault's methods ... defy conventional canons of research' (Vera, 1979: 590).

- 'Michel Foucault writes books faster than the responsible reader can consume them ... His books are speculative essays, deductive in natural reflections on the most problematic aspects of Western society, more important for what they suggest than what they prove' (White, 1977: 565). 
- 'Reader there is a secret you must grasp if you would understand ... [this book it is] not about sex-love ...Foucault may make an occasional effort to convince us he is interested, finally, in the flesh; but it is painfully evident throughout his work that he regards sex which he writes "sex' and describes it as 'the center around which sexuality distributes its effects" and "a complex idea that was formed inside the deployment of sexuality" - as no more than a troublesome excitation of the glands, the largest gland being the brain' (Vine, 1979: 918-920).

- 'In Foucault's account there never was a dirty little secret. With a repetitiveness bordering on insult, he insists that for generations we have been compulsorily prolix about sex. But if the smiles of others are at issue, psychoanalysts will grin when they read that such chronic jabbering is evidence that we are not repressed. Nor will it do to cite My Secret Life as evidence of Victorian sexual prattle. The canonical texts of England are more discrete' (Adamowski, 1979: 41).

- "Is he trying to discover some new and true fact about our sexuality, or is his "history" merely an exercise in virtuosity and futility - an entertainment for dilettantes at Columbia, Johns Hopkins and Yale? Does "charlatan", a French word, order a French thing like the Foucault phenomenon?' (Adams, 1979: 86).

- 'The trouble is that a method that worked well enough in earlier books is here imposed on a subject altogether more elusive, a subject in which every reader is a kind of expert. Having been deprived not too long ago of the mysteries of God and the soul, we are not anxious to be deprived of the mystery of sex. This is not the fault of Foucault's book. It is, instead, the result of the extraordinary mystifications that surround its subject and envelop even its most sympathetic readers' (Poirier, 1979: 29).

- 'Foucault's foray into the field of the interpretation of classical antiquity is, then, only partially successful. It is more valuable for the problems it sets than for the answers it offers, though it establishes well enough that our preoccupations with sexuality were not those of the ancient Greeks: they had no sciences as psychology pronouncing on sexuality, no popular obsession with the subject, let alone any equivalent to its modern commercial exploitation. But when he deals with the themes that are made explicit in the ancient debates, pleasure, desire, love and so on, while he has much to say that is subtle and penetrating, one of the chief weaknesses of his analysis turns out to be one that we might least have expected from a critic who had earlier insisted on the need for a total archaeological excavation of the past. It is as if the long immersion in unfamiliar source material diverted his attention from one of the more important lessons he had himself taught about the need to study ideas in the full complexity of their political setting' (Lloyd, 1986: 28).

\section{Those Who Praise:}

- 'In one short and powerful volume the noted French historian and philosopher Michel Foucault has dramatically changed the field of sexual history' (Gilbert, 1979: 1020).

- 'Foucault's books 'involve the meaning of liberty in the modern world. Michel Foucault is one of the few living writers who can, I think, write about this subject deeply, interestingly, and without the least trace of cant' (Sennett, 1979: 101).

- The later Foucault disavows any wish to reduce questions about subjects to questions about power. His last books offer, alongside his earlier studies of relations of knowledges and types of power relating to individuals, a study of relations of individual self to self, of a pagan "culture of the self". They do not, as has sometimes been supposed, mark Foucault's late conversion to the cause of a "theory of the subject". For Foucault, the 
"subject" never means a basic knowable substratum of our being but only a mode of existence shaped and formed by particular practices; ancient ethics illustrates this point because it is not centered on a science of the soul or psyche, but on an art or technique of living; and ancient sexual ethics is largely concerned with an art of everyday living which maintains the individual in a posture of autonomy. Reconstructing the ways in which early Christianity inherits various parts of this culture is the later Foucault research strategy for explaining the genealogy of the Western "man of desire". In some later interviews Foucault makes clear his lack of nostalgia for the specific (and conspicuously phallocentric) content of these Greek and Roman doctrines of sexual conduct. What he does seem to appreciate, or at least commend as an option worthy of consideration, is the notion of a morality of personal conduct in the form of an "aesthetics of existence', the idea that inventing different styles or ways of living can be an intellectually and morally interesting pursuit. People who themselves favour a militant style of existence are apt to interpret ideas like these as indicating Foucault's final lapse into an irresponsible, depoliticised aestheticism, a vice which some sections of the left are traditionally quick to suspect homosexuals of' (Gordon, 1988: 22).

- 'His work is aimed at destroying belief in a relatively fixed human nature - especially in a fixed nature of desire. The truth of the "The History of Sexuality", as opposed to its undoubted intellectual fire, depends on whether or not he can do this. If he can, "The History of Sexuality" will be a landmark of twentieth-century thought' (Sennett, 1979: 106).

\section{The Fence Sitters:}

- The old model of oppression says there is a who: some identifiable party is organizing the lives of other people; or, as a result we are not allowed to do certain things. Volume 1 of The History of Sexuality (1976) is a polemic against that old model ... This book is, as Foucault remarks in one interview, not about sex' (Hacking, 1981: 34).

- 'this introductory volume seems so disconcertingly to balance between true brilliance and graceless pedantry' (Amato, 1981: 200).

- 'Once Kierkegaard urged the claims of the existing self against Hegelian "system". Now we have a systems-analyst who urges - against our over-sexed self - the claims of nonexistent bodies. One thinks of Lear: "Nothing will come of nothing"' (Adamowski, 1979: 42).

\section{Power/Knowledge: Selected Interviews \& Other Writings 1972-1977 [1980]}

\section{The Doubters:}

- 'Foucault 'writes with that mixture of authority, arrogance and paradox, that in Paris are signifiers of Mind ... One of the marvellous tactics of contemporary French intellectual rhetoric is a lofty refusal to name one's foes (real or straw). Small fry can engage in polemics, but among the great a belle indifference secretes charisma ... Foucault becomes the kind of academic who spawned that nasty reply to the question, "Why are academic politics so bitter?" "Because the stakes are so low." (Adamowski, 1981: 3132). 
The One Who Praises:

- 'Scholars remind us that the facts are vastly more complex than what Foucault describes ... No matter. His histories stick in the mind. We can add our own corrective footnotes at leisure. These histories matter because they are in part political statements. They are also what I call philosophy: a way of analyzing and coming to $\mathrm{n}$ understand the conditions of possibility for ideas - not only ideas of disease or insanity or imprisonment but also the traditional concept of epistemology, namely knowledge, and of ethics, namely power' (Hacking, 1981: 32).

\section{Dits et Ecrits, 1954-1988}

- 'Virtues which one can see Foucault himself striving to demonstrate here, and which have not always figured in his international reputation, include perseverance, restraint and responsibility. From the 1980s, a decade after his semi-revolutionary campaigning activity, loosely allied with the Maoists, over conditions in the French prisons, one finds Foucault in sober dialogue with criminologists at Louvain on forms of punishment alternative to the prison, and in searching discussion with a French trade-unionist from the CFDT (a contact made during campaigns to support Solidarity) on changes in the welfare state and health-service policy, principles of government and relations between government and the governed: themes and ideas which anticipate much of the tone and substance of current reformist discourse in Britain ... Foucault's distinctive form of action seems to have been a kind of straining at the bounds of identity ... He has become a whole climate of opinion' (Gordon, 1996: 10).

\section{The 'Death of French Intellectual Hegemony': George Steiner's Splenetic View!}

I prefaced this survey of these reviews with a brief analysis of Armstrong's review of Foucault and offered an analysis of how his review exemplified a personal reflexiveness, displaying an ad hominem style that denigrates both the reviewer as well as the subject. The difficulty he had with much commentary is that it expresses 'an exegesis, which listens, through the prohibitions, the symbol, the concrete images ... ever secret, ever beyond itself' (1973: xvii). It was a representative example of the type of critical opinion that Foucault found so distasteful. For example, in the preface to The Birth of the Clinic he sets out his thoughts on the function of 'commentary' (1973; c.f., 1991d: 180). He wanted to rescue 'history from the density of discourse'. His belief being that if we can determine what 'systematizes ... [discourses] from the outset' then we can apply that knowledge in such a way that we remain open to new discourses and 'to the task of transforming them' (1973: xix). How densely and solidly so many reviewers remain caught up in their own discourses has been apparent. I conclude this section on the reviews themselves by reassessing the substance of George Steiner's attack on Foucault as another example of the scurrilous style of ad hominem attack that he disdained. 
Steiner's general review of Foucault's major works, called Power Play, in the New Yorker on March $17^{\text {th }} 1986$ is an extraordinary diatribe. Before undertaking a reconsideration of Foucault's work, some of which he does value - Madness and Civilization, for example, is defined as a 'masterpiece' - he sets out to demolish him personally. For example, he defines Foucault's homosexuality as an enforced secrecy and evasion. It is perhaps revealing of Steiner's concern that the substance of his review is to refute Foucault's arguments in The History of Sexuality, the reading of which he describes as 'encountering banality'. The review starts with an evocation of the death of those French intellectuals of whom he has endured perhaps too much of their force within American intellectual life (c.f., Colapietro, 1988):

Death, sometimes in a bizarre cruel humor, has all but ended a period of French sovereignty over philosophic, linguistic and anthropological speculations in the West. In rapid succession, Sartre, Roland Barthes, Jacques Lacan, and Michel Foucault have died. (Steiner, 1986: 1)

He sees power as the 'constant - indeed obsessive - pivot of Foucault's concerns' and defines his portrayal of these ideas as 'close-clustered and rhetorically hectoring'. This wilfully disregards Foucault's revision of his own thought since he explicitly moved away from a consideration of power per se. Together with his earlier similarly caustic review of The Order of Things in the New York Times Book Review of February $28^{\text {th }}$ 1971, his splenetic view of Foucault merits separate commentary. If only because it represents the strength of that section of American intelligentsia, represented by Steiner, which was never able to 'digest' Foucault.

For whatever reason Foucault responded publicly to Steiner's 1971 review - a most out of character action. We can only speculate as to the reason for this intellectual flurry. Steiner wrote:

French intellectual life is a scenario. It has its stars and polemics, its claques and fiascoes. It is susceptible, to a degree remarkable in a society so obviously literate and ironic, to sudden gusts of lunatic fashion ... Now the Mandarin of the Hour is Michel Foucault. His arresting features look out of the pages of glossy magazines. (1971: 8)

The most obvious 'fact' to be taken from Steiner's two separate reviews is his long-term apprehension about the possible hegemony of French intellectualism. One looks in vain in these two reviews for any reflective awareness, let alone appreciation, of his personal xenophobia. Whatever the nature of the turgid and illogical prose that he objects to in Foucault one finds little of this specific ad hominem repartee in Foucault's work that 
Steiner adopts as his norm. Foucault was uncharacteristically goaded to respond to Steiner's attack on his integrity. Indirectly and obliquely he aims his arrows:

All criticism will appear as transformations, proximate or far-ranging transformations, but which all have their principles and their laws. And these petits textes with the sloping brow, the crooked legs, and the veering eye, that one commonly despises, will enter the dance where they execute movements more or less honorable than the others. One will no longer seek to reply to them or silence their din, but rather to find reason for their misshapenness, their lameness, their sightless eyes, their long ears. (1971b: 57)

This is happily mischievous stuff but leaving aside the obvious hyperbole there are clear indications of the differences in the two men's approach to the world of the intellect. In both of his reviews Steiner attacks the person of Foucault before considering the import of his ideas. Anecdotally one wonders whether it was actually these attacks Foucault had in mind when he wrote, some years later, about the hurtful use of words like 'demolish, destroy, reduce to silence, bury' (1988d: 324). Consider Steiner again, elaborating in the same critical vein: 'an honest first reading produces an almost intolerable sense of verbosity, arrogance and obscure platitude. Page after page could be the rhetoric of a somewhat weary sybil indulging in free association' (1971: 8).

In another 'feint and jab' Steiner (while acknowledging that The Order of Things was a serious work of scholarship and intellectual analysis) still argued that Foucault 'must draw, at many points, on the work of predecessors and contemporaries'. He found Foucault's lack of rigorous cross-referencing totally unacceptable. Though, in respect of Madness and Civilization, Gordon attributes the blame for this to the translators who left out nearly two-thirds of Foucault's references and footnotes (1990a, 1990b). As Steiner continues, the 'trouble is that Foucault speaks as if he were a solitary explorer, opening up silent seas ...The consequence ... is a kind of breathless parochial grandeur' (1971: 29). Foucault's riposte to this jibe about referencing was to argue that 'with this assertion by Mr. Steiner, one is in the domain of pure invention' (1971b: 60).

When Foucault accuses Steiner of attacking his book from a position of 'decreasing entropy' we can see why he saw it as 'greatly more seducing, more difficult, and more creative' than other critical opinions. The reason why he thought this is an example of his sustained criticism of the 'limits' of a 'reason' that will not examine its 'practices'. He defined Steiner as 'parting from the actual book, with all that he can muster of the familiar, the all-ready known, and the probable, of fabricating the most improbable phantasm imaginable' (1971b: 59). This was in response to Steiner's description that 
Foucault's ideas were a 'weary sybil' - a phantasm'. It is clear that, for Foucault, such imaginative hyperbole is totally distracting and he despaired at the imagery that went with such metaphors, especially the requirement to identify your protagonist as an enemy, whether of class or society, and to triumph over them. As he described to Trombadori, what 'is tiresome in ideological arguments is that one is necessarily swept away by the "model of war". This "grand scheme of ideological struggle has really disturbed me [he continued]. First of all because the theoretical coordinates of each of us are often, no, always confused and fluctuating, especially if they are observed in their genesis (1991d: 180).

The misuse of criticism and denial of the personal reality of those with whom you disagreed were aspects that troubled Foucault (1988d: 324). For what he so often railed against was precisely this misuse of ideas because he thought it would lead to greater oppression. He sees Steiner 'mustering' all that is familiar and applying the 'all-ready known' to attack ideas which seem to threaten that reasoned 'citadel. He was disgusted with this form of ad hominem attack because it represented an unwillingness to examine its own reasoned exclusions and judgments. He thought Steiner had transformed his book 'into a sort of monster of incoherence that only a furious mind, and by only the most improbable of chances, could have imagined' (1971b: 59).

Steiner concludes his initial review by stating that 'something of originality, and perhaps, of very real importance is being argued in these often rebarbative pages. Can it be hammered out, though necessarily in a simplified, abbreviated form' (1971: 8)? 
Steiner's final riposte is to dismiss Foucault's unusual public disclaimer as the commentary of 'an enraged prima donna' (1971: 59). That exchange occurred in 1971 but Steiner returns to the fray in 1986, obviously, we note, after Foucault's death. Is it too much to see the 'gloat of the survivor' in Steiner's phrase with which he begins his review article which talks of death's 'cruel humor"? To be more explicit, how else can we interpret the following:

... certain enforced secrecies and evasions veiled his personal existence. This obsessed inquirer into disease and sexuality - into the mind's constructs of Eros and into the effects of such constructs on the body politic and on the individual flesh - was done to death by the most hideous and symbolically charged of current diseases' (1986: 105).

Such personal attacks must ultimately be reflexive of our own hidden 'enforced secrecies and evasions'. Foucault made no secret of his homosexuality as all of his biographers make clear (c.f., Deleuze, 1988; Eribon, 1991; Macey, 1993; Miller, 1993a).

Steiner explicitly declares his hand when he says that 'Foucault's vision ... belongs to the ever more fascinating and exemplary history of the relations between homoeroticism and modernity' (1986: 105). Steiner certainly has had time to polish his stiletto! Yet one wonders in Foucault's earlier response, where he rejected the criticisms of those who wrote from within the 'familiar, the all-ready-known, and the probable', whether there was not a greater respect shown in that approach to the issues of humanitarian and communitarian life that Steiner so obviously believes he represents! Nonetheless, after an execrable start Steiner's 1986 commentary elides into a much more reflective and 'softer' view of Foucault's significance. As he concludes, Foucault's:

... finer work does stand. Seizing upon the inheritance of Nietzsche and on something of the Master's rebellious impatience, Foucault has, in his studies of repressive institutions and of the mind's servitude to what is frozen in language, been a powerful god. What enfeebles his last, and posthumous, enterprise is not only the intractable immensity of the topic - not even in Freud do we find a coherent inward genealogy of the sexual - but, it may be, a terminal isolation and unresolved dark in Foucault's own consciousness. There are needs that the mind articulates at its peril. (1986: 109)

But did all of this more considered reflection and personally revisionist sympathy for Foucault have first to travel through Steiner's explicit anti-French xenophobia and his implicit as well as explicit homophobic disdain? Is not his mind and language frozen in the very self-same servitude with which he so cavalierly admonished of Foucault? This stance, which demonstrates the 'unresolved dark' in Steiner's mind as well, weakens the ethical force of his critique. It adds nothing to it, for it so obviously reveals the righteous and magisterial traps of modernist 'authorship' that Foucault laboured hard 
for us all to recognize. The exchange between the two men stands then as an exemplar of misunderstanding, envy, disdain but, ultimately, not of total rejection. Such contretemps are revealing not only in outlining the content they are explicitly framed around but, equally, because they fashion another kind of awareness of what we fight so strenuously about in wanting to get our social analyses 'right'!

\section{Conclusion}

This chapter marks the end of this discussion of the various 'Foucault's' and the amazing response that has swirled around him personally as well as in the more formal criticism of his ideas. Given the nature of that critical response I have argued that much of it bespeaks a particular reflexivity, an intellectual projection of indecipherability and incomprehension, or the assumption that there is a quality of understanding in his work that is elusive and arcane.

Generally, as I have briefly indicated in selecting the previous extracts of these reviews, one does not find often the considered reflection about Foucault that satisfies the mind. These reviews are too quick to assign him to irrelevancy or, alternatively, too ready to align him with their own preconceptions. So often the descriptive metaphors are rigidly dismissive or equally rigidly praising of Foucault. For example, the critical language is, as he suggested, so often expressed in words like 'demolish, destroy, reduce to silence, bury' (1988d: 324).

It is a feature of his overall work that his ideas can be taken up like bits and pieces from his 'toolbox'. Foucault, as we have seen, explicitly encouraged this (Mottier, 1995: 27). While we can understand that he so often cast his ideas as 'experiments' and not theories ('I don't develop deductive systems to apply uniformly in different fields of research. When I write, I do it above all to change myself and not to think the same thing as before' (1991d: 27), that style has reinforced an approach to his work that is often 'spotty and full of gaps' (Goldstein, 1984: 172). His contention that we should not in fact ask 'who he was' or require him to 'remain the same '(1972: 17) is not sustainable, for as a 'man of ideas' he will be assessed and/or appreciated as an important interpreter of modernity. 
Said's conclusion, that Foucault was 'the unusually impressive author of his work' and that he could not be anonymous, is incontrovertible (1974: 28). We may well accept his claim that 'I don't construct a general method of definitive value for myself or others' and we may equally well consider that the character of his work 'is instrumental and visionary or dream-like' (1991d: 29). When he argued that our 'speaking' can never be finished then we should perhaps be less critical of his reviewers efforts to find a way to 'speak' about him (c.f., Goldstein, 1984). He did, as Said argued later, have an 'uncanny ability to invent whole fields of investigation' but it is clear that so many of his reviewers were unequal to the task of assessing the importance of this (1991: 5). However, he could not fashion such an impenetrable 'mask' that all efforts to 'peer beneath it' are illusory.

We are now more able to consider his overall significance within the history of ideas and to determine the 'stable features behind his projected facelessness and a definable pattern underneath his labyrinthine movements' (Seigel, 1990: 274). The efforts to understand Foucault, despite his protestations about authorship, are valid forms of inquiry. While undoubtedly the style of his prose and ideas are never easy to apprehend, let alone appropriate, his enduring 'effect' is that we cannot begin again the tasks of social inquiry without traversing some of his 'ground'.

Perhaps it is a measure of the difficulty that so many reviewers had in critically appraising Foucault's works that so few understood how to approach his ideas from the point of view of 'experience' and not the 'Truth'. So many of the reviews we have considered are written from within the epistemological framework of specific precursive rationalizations. So few understood, or valued, Howard's argument that Foucault's 'marvellous' poetic language had the power to transform and to invest words with new meanings (1971: 22). That he explicitly challenged the rationalizations of reason, implicit in the assumption of the dispassionate intellectual, eluded many of his commentators. He wrote, as he said to Trombadori, in order to 'tear the subject from itself' (1991d: 31 32). He wanted his readers to enter into their own world of 'limit-experiences' and desubjectify the rationalizations that he defined as the 'prison' of normalization.

Few, however, were able to understand his metaphorical notions of the 'journey' or 'travelling' expressed, for example, in his depiction of the water-borne journeys of the mad on the Narrenschiff in Madness and Civilization. We are left with the images of a 
'carceral archipelago' - the complex notions of how various societies continue to oppress 'its citizens in the name of an original spirit of laws'. It is no longer possible for any writer to assume an automatic place of magisterial inquiry and to mask the 'opportunism [of their ideas] behind a common original "tradition"' (Said, 1974: 37). If Foucault's most enduring legacy is this ability to unsettle reasons' settled sensibilities then perhaps he will have provided us with a language of critique that does allow us to imagine that 'one can begin again to study, act, write - again' (Said, 1974: 37). 


\section{Chapter Five}

\section{'Il faut défendre la société': xxxviii Omnes and Singulatim}

Man spins his web over the past and subdues it, thus he gives expression to his artistic drive - but not to his drive toward truth or justice. Objectivity and justice have nothing to do with one another. (Nietzsche, 1983: 91)

The characteristic feature of power is that some men can more or less entirely determine other men's conduct - but never exhaustively or coercively. A man who is chained up and beaten is subject to force being exerted over him. Not power. But if he can be induced to speak, when his ultimate recourse would have been to hold his tongue, preferring death, then he has been caused to behave in a certain way. His freedom has been subject to power. He has been submitted to government. If an individual can remain free, however little his freedom may be, power can subject him to government. There is no power without potential refusal or revolt. (Foucault, 1991b: 253)

Social policy theory has generally drawn heavily on distinctive sociological approaches to the study of power, politics and socialization. I will take up these concerns by first surveying and discussing the reception of Foucault by sociologists and whether his ideas can reasonably contribute to a possible reformulation of social theory. These preliminary sections lead into a review of several major sociological criticisms of Foucault. Namely, that he had no progressive epistemology; that he provided no sustainable analysis of history; and that his complex reworking of what sociologists had traditionally interpreted power to mean was unsustainable. How the governmentality literature has contributed to a Foucaultian perspective in current speculations and debates about the eclipse of the welfare state and its 'transmutation' into a welfare society is briefly outlined. The chapter ends with some comments on Foucault's intellectual nomadism and shows how neither sociology, philosophy nor history (constantly ambivalent about Foucault) could either 'lay claim to him', nor easily 'dismiss' him.

The controversial 'place' that Foucault has assumed within sociology reflects some of the problems that social policy, given its close alliance with sociology, similarly has in applying his insights to its characteristic concerns. For example, the issues surrounding unemployment (one of social policy's major themes) have almost become 'taken for granted as an ahistorical descriptor in much sociological writing'. Given that the theoretical interests of both sociology and social policy are necessarily interwoven some overlap is inevitable (c.f., Helliwell and Hindess, 1998b; Pearce and Tombs, 1998). Rose outlines how in European debates social policy, as a defined category is even 
further constricted, and 'has come to be understood as policy around work' (1999: 164). The 'limitation' this imputes to the scope of social policy theory requires a renewed challenge. As O'Malley et al. contend, new research 'shows ... [unemployment] to have emerged as a category of governance linked directly to the envisaging of worklessness as a characteristic of populations or, more precisely, of 'economies', rather than of individuals' (1997: 502). Analyzing the practices of welfare policy - as specific instances of Foucaultian 'limit-experience' and normalization - serves a critically reflective purpose within social policy (c.f., Hewitt, 1983, 1992, 1994; Leonard, 1997; O'Brien and Penna, 1998a, 1998b; Rose, 1999; Squires, 1990).

\section{Foucault and Sociology: An Ambivalent Involvement}

What Foucault meant by 'Il faut défendre la société' is perhaps best translated as 'we must defend our social constructs', that is the kind of society that has been built including the notion (in France) of republic, of social programs, of government participation in the affairs of the nation. It is too compressing of his intention simply to elide the phrase into the English 'social' or 'society'. He provides no formula for such an extensive critique since his approach to genealogical research is that it must 'begin from an analytic of relations of power', not investigate 'structures, or ideological defences erected to justify explicit forms of power' (Caputo and Yount, 1993: 7; Rose, 1999, my italics). He examined the genesis of fluctuating ideological certainties, not at the level of the expressed rhetoric but as it was variously practised - which is the core of his genealogical method (c.f., Bové, 1980; Gutting, 1990; Schneck, 1997). ${ }^{\text {xxxix }}$

Characteristically, sociological approaches to the study of power, politics and socialization involve themes of 'what actually happened' and 'what government is really about' (O'Malley, et al., 1997: 502). While the 'information' that sociology draws upon has apparent similarities to Foucault's genealogical analysis of the detailed practices of politics and administration he constructs no progressive or alternative view of history. His was no alternative 'theory of modernity, but - more modestly - some theoretical pointers, some substantive insights, and what might be called principles of dedramatization that may be of use for those working in historical sociology' (Osborne, 1994: 487). Sociologists can argue that consideration of his work, couched as 'both a social fact and a problem to be explained', would provide one reason to take him seriously. Nonetheless, it is undeniable that Foucault posed considerable dilemmas for 
traditional sociology, and many are disinclined to consider that he has any effective 'place' within the discipline (c.f., Free, 1993; Fox, 1998; Garland, 1997; Lemert and Gillan, 1977; Malpas and Wickham, 1995; Osborne, 1994; Pavlich, 1995; Procacci, 1989). For example, Szakolczai suggests, more than somewhat defensively, that a:

... proper sociological analysis of the reception [of Foucault's work] would not only have to collect and digest a huge amount of facts and texts, but should also manage the sensitivities both personal and collective it is bound to provoke. (1998a: 1403, my italics)

Such an approach to theoretical analysis frames such questions in an a priori fashion namely, how do powerful interests interpret, construe, manoeuvre, implement, and shape the social and political world? Sociology presents 'itself as a generalising or 'nomothetic' discipline, one that formulates theories to be applied across a range of phenomena, while it attributes to history the 'idiographic' description of the unique and the singular' (Dean, 1994a: 7).

In line with his emphasis on 'limit-experience', and the processes of normalization Foucault's work does intentionally cross both disciplines. He was interested to apply the information he discovered to critique 'discourses as rule-governed systems for the production of thought'. But he did not 'allow his own heuristics to congeal into a fixed, formal method. His genealogies looked towards different 'data' on which to base research assumptions. His work led him to the 'gray, meticulous, and patiently documentary' record of information, not typically applied within sociology. Every 'statement of method, ostensibly committed to the same overall framework, reveals subtle, and sometimes gross, shifts and reconfigurations' (Dean, 1994a: 14). He provided no 'system', no over-arching explanatory paradigm, and consequently those sociologists who sought such explanations have not found Foucault much to their taste!

Foucault's imagery of palimpsests, an original manuscript that is effaced and overwritten, aptly describes the orientation of his research work and provides a clear description of how his approach straddled both sociological and historical methods. It is his 'mix' of singular inquiry that is presented in ways that can appear to have such far-reaching implications which reflects the difference between his ideas and mainstream sociology. It involved the careful unscrambling of 'entangled and confused parchments' and the deciphering of 'documents that have been scratched over and recopied many times' (1984c: 76). His unique methodology and its particular research focus helps us to 
understand why his 'invitation' was to use his ideas as 'bits and pieces' out of his toolbox (Mottier, 1995). Expressed succinctly, his 'ethos of analytics of governmentality is very different from that of sociologies of governance' (Rose, 1999: 19). And for this reason we cannot easily refashion Foucault as a social theorist or consider that he is really a 'masked' sociologist.

What Foucault proposed in his analysis of the 'practices' of power was a different theoretical viewpoint, a new perspective - a constant quest for the possibility and meaning of a freedom that was not 'subject to government' (c.f., Rose, 1999). He saw freedom, however elusive, residing in an examination of 'limit-experience' where freedom meant understanding the form of rationalization that establishes the grounds of our politics, and the particular practices of normalization and subjectification. More radically, perhaps, he also saw it as exposing the narrow limits of the sociological perspectives that Osborne is quick to defend.

Establishing his thesis of 'limit-experience' was essential to Foucault's explication of exclusion. It involved asking 'what rules permit certain statements to be made' (Philp, 1985: 69). For some of this he turned to historical analysis. For example, as Goldstein argued, "no historian has disputed that a "normalization" through supposedly humanitarian means was what the men in bourgeois government typically strove to achieve' (1987: 284). Foucault's histories were 'directed towards those whom a society deprives of acceptable discourse, or excludes from its self-definition'. Indeed, for some, ideas about 'modern citizenship ... [are] bound to the exclusions of the nation-state' (Rajchman, 1991: 105). As Foucault argued:

Traditional sociology, sociology of the Durkheim type presented the problem rather in this way: How can society hold individuals together? What is the form of relationship, of symbolic or affective communication that is established among individuals? What is the organizational system that permits society to constitute a totality? I was interested by the somewhat opposite problem, or, if you will, by the opposite response to this problem, which is: Through what system of exclusion, by eliminating whom, by creating what division, through what game of negation and rejection can society begin to function? (1991e: 28, my italics)

$\mathrm{He}$ could write of the requisite transgressive aspects of such self-reflection about 'limitexperience' yet, paradoxically, remind us of the difficulty inherent in this. For example, he also argued that 'power is co-extensive with the social body; there are no spaces of primal liberty between the meshes of its network' (1980a: 142). Bevir, echoing this argument, commented that 'modern power renders us insipid and uniform while 
pretending to liberate our true, inner selves (1999: 75). The paradox at the heart of this conjunction of ideas is that, both metaphorically and practically, it presumes that it is possible - even within the context of his overwhelming analysis of power, subjectification and the inescapable processes of normalization - to achieve a measure of individual freedom. However, as Rose correctly concludes, freedom is always considered an 'artefact of government' (1999: $61 \mathrm{ff}$.).

How to resist what he called the 'determinate situation of power' (his phrase that captures the processes of subjectification that fashioned the need for such paradigms) was a question that preoccupied Foucault all his life (1991d: 157). Implicit in this critique of 'our present' that he thought relied too heavily on the objectivity of reason lies an ethical challenge, vital to social critique. Nonetheless, where he looked to find the ground for such effective resistance has often disturbed his critics (c.f., Osborne, 1994; Pels, 1995). He neither looked to rework any Freudian themes of psychological liberation, nor would he apply his genealogical analytical themes to develop some revamped Marxian quest for political liberation (c.f., Gold, 1990; Hiley, 1988; Minson, 1980). He did not want to get involved in any 'grand schemes of ideological struggle ... because [as he argued] the theoretical coordinates of each of us are often, no, always, confused and fluctuating, especially if they are observed in their genesis' (1991d: 180). What he rather celebrated was the ambiguity of politics, and while he assumed that something was 'always out of joint ethically' this did not eviscerate any political application of his ideas (Connolly, 1993a: 378). He proffered a different commentary, one unencumbered with the discursive 'controls' of the past. His approach, as Rose (echoing Nietzsche) suggested, was an untimely use of history (1999: 13).

\section{The 'Masked Sociologist'!}

Whether we can finally resolve Foucault's paradox about the power of the state and the demands of idiosyncratic privacy is still an open question. Travelling some distance with him in this quest sheds some light on the complex functions, strategies and purposes of our current welfare and social politics. However, it is the Foucault who pays 'careful attention to the techniques of person-formation and the institutional programming of conduct' that is central to how his ideas may be applied to social policy theory (Osborne, 1994: 487). Philp interprets this as Foucault's aim 'to unmask the operation of power in order to enable those who suffer from it to resist' (1985: 76). 
Deliberately understating it, Foucault described this 'unmasking' as 'a little idiosyncrasy which has found itself a system'. He wanted to give 'voice' to 'obscure personages ... [those] destined to pass away without a trace' (Morris and Patton, 1979: 78-79). We need not, even if we could, look toward the 'Masked Sociologist' for guidance! It is Hacking's 'fact-lover' (1981: 32), and not Megill's 'Prophet of Extremity' (1985) - the 'wilder' Foucault, denizen of a carceral archipelago, that is applicable here (c.f., Osborne, 1998b).

Foucault would not allow much 'free-space' within this analysis where somehow the totalizing effects of normalization and subjectification could all be 'pushed-away' for a while. The metaphor implicit in his analysis of governmentality is that there can be no such 'rest' from all of this - no 'holiday' from power - for what we need to understand more profoundly is our requisite complicity with the facts of our own governance. 'Practicing criticism [he therefore argued] is a matter of making facile gestures difficult' (1988f: 155). As Goldstein outlines, he:

... questioned the necessary continuity of history. Even after he abandoned his focus on radical epistemic ruptures that marked his "archaeology", and began in the 1970's to call his investigations of the past 'genealogy", historical time for him still moved in a kind of staccato fashion. He continued to suppress those gradual processes of historical transition and transformation through which the components of modern rational civilization, including psychiatry, had come into existence ... Foucauldian "genealogy" was, after all, a deliberately polemical use of the past to designed to debunk the most cherished values and institutions of liberal culture by showing that they had originated in mere historical contingency. To locate them at the end of a long, continuous development would have been, for Foucault, only to dignify them. (1987: 3)

Such an approach to disrupting the function of power and undermining an understanding of the trustworthiness of knowledge sets in train much of the typical style and pattern of criticism made of him (c.f., Digeser, 1992). For example, if 'government' is inescapable, the functioning of power capillary and ubiquitous, and there are no reliable normative dramas and expectations to serve as moral or ethical guides (no canonical 'texts' to provide internal maps, indeed no 'history' to guide choices), then why fight? And further, if we could, where could the fight possibly be enjoined (c.f., Campbell, 1998; Osborne, 1994, 1998a, 1998b)?

These were also Foucault's questions - they were his 'daemons' too. They are part of his restless dissatisfaction that led to his theory of 'limit-experience', and reflected his sense that life proceeded from a series of 'seismic crises', as Deleuze highlighted in his 
survey of Foucault's intellectual career (1995: 104). However, because his 'answers' were different we cannot simply presume that he had no ethical base and no politics (c.f., Patton, 1989). Whether we dismiss his work and rail against his overall project as if he were an extreme example of Nietzschean nihilism his impact has been such that the structures and patterns of our social theories are inevitably now to be interpreted in a post-Foucaultian manner. Kemp summarises this initial critical theme well when he suggests that Foucault provided the tools to analyse the 'history of the power of oppression' but now we need 'someone to write a supplementary history of the power of emancipation. This would be the history of resistance and generosity' (1984: 105). ${ }^{x l}$ As Rose proposed:

It would ask if there were ways of organizing our concern for others that did not seek to set them free - relations of obligation, of commitment, perhaps evoking an older sense of care. It would help us to calculate the costs of being what we have become; hence it might allow us to invent ways of becoming other than we are. (Rose, 1999: 97)

To exclude Foucault from this 'promise' ignores the latter Foucault of The History of Sexuality (c.f., Lamb, 1995). It also excludes the Foucault who did suggest that he had a social and political purpose in writing Madness and Civilization (1991d: 77, c.f., Gordon, 1990a, 1990b).

\section{A Sociological Critique of Foucault}

English speaking sociology generally has not found it easy to 'digest' the fully French 'Foucault' (c.f., Dean, 1994a, 1997; Donzelot, 1977; Fox, 1998; Goldstein, 1984; Harpham, 1988; Lemert and Gillan, 1977; Osborne, 1994; Smart, 1990; Turner, 1985, 1997). Nor has it valued even the watered down American version that disdained any of Foucault's apparent Nietzscheanism (c.f., Hinkle, 1986; O'Hara, 1992; Szakolczai, 1998a, 1998b; Thiele, 1990, 1991). Thiele commented that this American 'suspicion' about Foucault is so strong that it represents a particular hermeneutics within American sociology that 'resists' the excesses, as it sees it, of French social theory (1991). Colapietro also discusses what he sees as the American evasions of Foucault, and the unwillingness to accept his criticism of liberal reason (1998). From across the Atlantic Gordon wryly noted that 'trying to introduce Foucault's work into British intellectual life was like entering Cerberus at Cruft's' (1990b: 381)!

One way to attempt to respond to this question about his significance within sociological and social policy theory is to set out the general nature of the criticisms of Foucault that 
collectively deny the relevance of his work to any analysis of the social. That is an invitation to see whether the 'Foucault' that is revealed in these general sociological critiques is recognisable, or whether his ideas have sparked such reflexive negativity because of the 'critical shortfall' in their own assumptions? Denting the apparent hegemony of neo-liberalism in relation to social policy questions has proven no easy task? It is still an open question whether, generally speaking, his ideas have become a kind of negative focus for the relative impotence of critical theorists to 'reclaim' the power of their own former normative rhetoric? I do not intend a full rebuttal of such arguments it is the collective force of it (the patterning) that I want to highlight. This is an emphasis, in Rose's instructive phrase, that draws upon the power of 'small differences and weak generalities' (1999: 13).

\section{(1) Foucault's 'Epistemology': Is He Anarchist or Nihilist?}

Foucault posed an altogether more problematic task for critical theorists. While it is not too hard to understand what his position is, the problem seems to be what to do with it. He wanted, in creating a new theory of discourse, to dissociate it from the usual anchors that located critical theory (c.f., Ross, 1985). For example, he said that he wanted to:

... abandon any attempt ... to see discourse as a phenomenon of expression - the verbal
translation of a previously established synthesis; instead I shall look for a field of
regularity for various positions of subjectivity. Thus conceived discourse is not the
majestically unfolding manifestation of a thinking, knowing, speaking subject, but on the
contrary a totality, in which the dispersion of the subject and his discontinuity with himself
may be determined. It is a space of exteriority in which a network of distinct sites is
deployed ... It was neither by 'words' nor by 'things' that the regulation of the objects
proper to a discursive formation should be defined; similarly it must now be recognised
that it is neither by recourse to a transcendental subject nor by recourse to a
psychological subjectivity that the regulation of its enunciation should be defined. (1972:
55) It is Foucault's notion of caesura, his denial of an established synthesis and approach to discourse that is most troubling to the social 'scientist'. He lifted the idea of discourse away from individual inter-subjectivity and located it within what he described as 'fields of regularity' - the patterns and practices that construct the notion of subjective discourse. This emphasis on the form of structural analysis has occasioned much recent debate (c.f., Campbell, 1998; Dreyfus and Rabinow, 1982; Dumont, 1998; Hacking, 1998a, 1998b, 1999; Osborne, 1998a, 1998b; Poster, 1989; Raulet, 1983; Schram, 1995; Valverde, 1999; White, 1988b). 
What is more interesting though is how he split apart the paradox whereby we desperately defend our own subjective knowing within the traditions of reasoned debate. It is paradoxical because the privileging of subjectivity is made within the constraints of a certain tradition of knowledge making. This has led the human sciences, he argues, into a cul-de-sac whereby we avoid the self-critical recognition that we are 'avatars of the hermeneutic that has always existed in the Western world' (Foucault, 1998: 257). This hermeneutic, it appears, 'demands' an obeisance to the idea of progress, continuity and eschews Foucault's ideas of 'rupture', or more properly resistance to domination. What he claimed is that we are trapped within the very definitions of freedom that inform the patterns of discourses about reason and freedom. As he says, 'discourse is not the majestically unfolding manifestation of a thinking, knowing, speaking subject'.

This marks an enormous challenge to the Western history of ideas that so ardently seems to need the notion of an unbroken thread as part of an intrinsic self and cultural understanding. Certainly this is so in respect of the search for 'truth'. Whereas Foucault was initially preoccupied with power/knowledge, he came later in his life to the conclusion that what he was always really more preoccupied with were questions about truth - his exposition of 'limit-experience' (c.f., 1991d). He wanted to understand how differing preoccupations with truth had led to so much apparent bloodshed and that political power did 'turn around this obligation to truth' (1988b, 1988c). Querying the 'limits' inherent in such assumptions, he argued:

After all, why truth? And why are we concerned with truth, and more so than with the
self? And why do we care for ourselves, only through the care for truth? I think we are
touching on a question which is very fundamental and which is, I would say, the question
of the Western world. What caused all Western culture to begin to turn around this
obligation to truth, which has taken on a variety of different forms? Things being what
they are, nothing has, up to the present, proved that we could define a strategy exterior to
it. It is indeed in this field of obligation to truth that we sometimes can avoid in one way
or another the effects of a domination, linked to structures of truth or to institutions
charged with truth. (1987: 126) He did not see that we had yet determined any alternatives to these discourses - there was no 'strategy exterior to it' - but he did pose a fundamental attack on reasoned truth as the final arbiter of our politics. What he debates is not the subjective singularity of such activity but that it is 'a totality, in which the dispersion of the subject and his discontinuity with himself may be determined'. 
This apparent denial of 'truth' results in one of the most enduring patterns of the critical view of Foucault that he has snapped the thread of rational and reasonable discourse that holds the fragility of our human experience together. Dealing with the contingent nature of our own discontinuity is seen as a major threat to the defence of democratic institutions but it is vital to ask why this might be so.

- What is it that makes us so scared to re-examine these so-called 'fundamentals'?

- What is it that makes defence of 'truth' such a bastion of our security and epistemology, and why should such questions promote such counter-defensive hostility?

- Does it suggest that there is an uncertainty that is denied that lies at the core of such arguments?

The other major pattern of criticism revolves around Foucault's unwillingness to rely on 'words', as such, being able to carry within themselves all that he wanted to demonstrate. This takes us back into Deleuze's analysis that 'space' and 'seeing' are intrinsic to an understanding of his writing (1988). Discursive formation, the actual patterning of discourses cannot, according to Foucault, be contained solely within the speaking of words because the act of speaking - authorship - is only possible within a context mandated and regulated by a wider and more dispersed set of discursive rules and practices. Consequently, we come to the centrality of his argument that 'it is neither by recourse to a transcendental subject nor by recourse to a psychological subjectivity that the regulation of its enunciation should be defined' (my italics). Foucault lodged the problems of philosophy 'within the domain that can be called that of human finitude' (1998: 250, my italics).

This rejection of a transcendental subject highlights one of the most important patterned objections to his ideas, namely that our historical and discursive understandings must reflect agreement that the:

Western intellectual tradition exists in a state of continuous transformation. It is ruled by evolution within continuity. Changes do occur, more or less dramatically, but they only enrich the corpus as a whole, a corpus whose keepers are the intellectual historians themselves. (Poster, 1997: 135)

May similarly argues that the 'foundations of much of our knowledge - those subjective foundations whose locus is the human mind - are bound to a project which is at least political as it is epistemological' (1993: 70; c.f., Taylor, 1986, 1992, 1995). Such criticism of Foucault relies on an assumption that valid intellectual analysis 'obey' certain discursive rules. That precursive requirement, as May continues, 'imposes a burden on ... [any] discourse' that would challenge the foundations of modern knowledge. Turner, 
similarly, suggests that Foucault's work is fundamentally suspect because he celebrates 'the peculiar and esoteric as evidence of the irredeemable otherness and variety of human nature rather than [attempting] to locate those deep structures which ultimately organise the diversity of human culture' (1985: 197). But he completely misses Foucault's intention! The so-called 'antihumanist' is nothing of the sort. For example, as a counter to these assumptions about Foucaultian critique that he was nihilistic there:

... may be a certain irony in the fact that antihumanist discourse has provided the most significant directions in the theory of the subject [not sociology per se], but there is no paradox: for the thought of the death of man cannot but be - in the most insistent, engaged form - the thinking of man about man. (Burke, 1992: 115)

Foucault's challenge to these Humanist assumptions, as we shall see later in the discussion of his theories of historical analysis and power, is that these 'deep structures', on which Turner (1985), as a representative of much mainstream sociology, wishes to 'stand', are themselves discursively generated. They are not immutable and eternal. Bové presents the 'interpretive dilemma' accurately when he wonders how 'reasonable' it was for Foucault's 'reasoned' critics to oblige him to answer their questions 'about issues raised within the very systems of discourse that, as Foucault once put it, come from the very 'mind set' he was trying to critique' (1988: viii-xi).

The implicit pattern in all these criticisms is that it is not possible, as Foucault argued, for us to 'think differently'. Valid discourse, it is contended, can only operate within given patterns. For example, May argues, he 'does not have to offer a foundationalist metanarrative of his genealogical writings; he does, however, have to tell us how we can justify his discourse without one' (1993: 72). He continues, how can Foucault 'argue that the picture of the relationship between knowledge and power he has painted is a valid one, even in specific instances, unless he offers a means for justifying the validity of that picture?' (1993: 73). Without such justification, May asserts, Foucault's analyses can be dismissed as little more than ideology. However, this is always such an easy and empty mantra of abuse for adhering to such an injunction would render most of us dumb!

Foucault, to the contrary, suggested that how we resolve issues of 'validity' could not be separated from explicit aspects of systems of domination. The patterning of such criticism obviously depends upon a different set of ideological assumptions that the only 'valid' forms of knowledge are those that which extend, elaborate or criticize the 'unbroken strand of Western intellectual endeavour'. For example, the structure of this 
criticism is that valid discourse cannot accept that the 'world contains an infinity of meanings and thus that any interpretation is true only in relation to the meaning it explicates' (May, 1993: 79). Rejecting what he defines as an inherent relativism leads him to assume that Foucault's arguments are ultimately constricting - that the effort to 'think differently' leads nowhere:

$\ldots$ if the world really does have many meanings, then there is one interpretation of the world that embraces them all - the very interpretation which claims it has many meanings. Thus the ontological pluralism of the relativist is defeated in the very gesture by which it tries to establish itself: the world can contain many meanings, and thus be susceptible to many interpretations, only inasmuch as it sustains an embracing interpretation (corresponding to a single meaning) which is precisely what the relativist wants to deny. (1993: 80)

That such patterns of Foucaultian critique dismiss his challenge by arguing that he abandoned the 'rules' of discourse is instructive. But equally, that this may be an argument more indicative of the reflexivity of their thought, rather than Foucault's, needs further examination (c.f., Rose, 1999). Nonetheless, his ethical position and relevance to social theory does not depend on resolving such particular criticisms - the paralysis of the relativist or nihilist - but in applying his ideas to assess whether these discursive 'rules' are as immutable as May and others would contend (c.f., Blair and Cooper, 1987)?

There was, previously, a certain 'nobility' of thought in the apparent hope that freedom and reason might be able to be set within a metaphysical grounding that would establish the ineluctableness of such ideas. It is also clear that such 'longings' have remained just that. Foucault's disdain of the teleological and romantic in normative thinking is based on a similar recognition of the banality of being trapped within forms of social and political critique that will not acknowledge the possibility of contingency (c.f., Kolodny, 1996). For example, Ransom has argued that 'both violence and selection are involved in [Foucault's] ...construction of subjectivity' (1997: 40). He would have no truck with the arguments that indicated a moral source 'ambiguously lodged between established practices and a higher fugitive experience of intrinsic purpose floating above them' (Connolly, 1993b: 141). It was precisely this contingent aspect of our selves that preoccupied him. He said of any diagnosis of the present that it:

... does not consist in a simple characterization of what we are but, instead - by following lines of fragility in the present - in managing to grasp why and how that-which-is might no longer be that-which-is. In a sense, any description must always be made in accordance with these kinds of virtual fracture which open up the space of freedom understood as a space of concrete freedom, i.e., of possible transformation. (1983: 206) 
It is a reasonable assumption that much of the critical anguish about Foucault was generated because he explicitly disavowed locating arguments for freedom and reason within any discursive form that was metaphysical. In addition he abandoned the archetypal 'political calculus of domination and liberation' (Rose, 1999: 95). That the Left has remained wedded to such essentialist or foundationalist searches is at least one explanation for their relative impotence vis-à-vis neo-liberalism. As Foucault wrote:

To describe a group of statements not as the closed, plethoric totality of a meaning, but as an incomplete, fragmented figure; to describe a group of statements not with reference to the interiority of an intention, a thought, or a subject, but in accordance with the dispersion of an exteriority; to describe a group of statements, in order to rediscover not the moment or trace of their origin, but the specific forms of an accumulation, is certainly not to uncover an interpretation, to discover a foundation, or to free constituent acts; nor is it to decide on a rationality, or to embrace a teleology. It is to establish what I am quite willing to call a positivity ... If, by substituting the analysis of rarity for the search for totalities, the description of relations of exteriority for the theme of transcendental foundation, the analysis of accumulations for the quest of an origin, one is a positivist, then I am happy to be one. (1972: 125)

Laying out the 'dispersion of an exteriority' (namely, the rhetoric of common sense and obviousness) without being willing to examine the 'interiority' of such an intention does need to be debated. A form of political rhetoric that depends upon 'specific forms of accumulation' uses the weight of its rhetoric to overwhelm and not its specific 'trace of an origin'.

The overwhelming pattern of the complaint that some sociologists make against Foucault is that his ideas provide no agency. That there is no clear consequential path towards the 'march for freedom and progress' and that this represents the 'performative contradiction' that Habermas levelled at him (c.f., Habermas, 1986a, 1986b, 1987; Fraser, 1989b). Turner assumes that Foucault's reluctance to develop a 'proper' or defensible theory of agency must inevitably lead to the conclusion that he is a pessimistic nihilist (1985: 200). What is not clear is whether we can argue that his decentering of the subject is intrinsically pessimistic? Opening up the 'spatial' surround of specific discourses is not necessarily pessimistic. What he challenges is our uncritical reliance on the 'majestically unfolding manifestation of a thinking, knowing, speaking subject' (1972: 55$)$.

It can immediately be levelled that by establishing a patterning of Foucault's criticism I have fallen into the same 'search for a totality' that he disdains. This is a differing 'form' of the 'visionary intellectual' that Deleuze saw in Foucault. However, I think this can be 
resisted, for trying to 'see' Foucault may be more reflective of his subtle purpose than trying to 'unpack' him. That he did cause so much offence to the settled rationality of 'continuous transformation' - the core of the Western intellectual tradition - ought not to be surprising. The complex conceptual 'traps' that he laid are easy enough to see, but not to avoid (Poster, 1997: 152).

\section{(2) What Manner of Historian - Did Foucault Really 'Murder History? xli}

Davidson has wryly commented that 'many people seem to agree that Foucault is very good at something; if they are historians, he is a great philosopher, and if philosophers, a great historian' (1984: 108). Foucault had little patience with an approach to history that implied any reverence for the 'facts' of the past. Some critics consider his critical history of madness, and the loops and whorls of reason, as a kind of 'antihistory'. For example, he made 'the present into a past which we leave behind, and not into a history which we tightly embrace as our own ... [It is] a "disremembrance of things past"' (Roth, 1981: 44). Philp, similarly, concluded that Foucault could have no 'progressive view of history. Against order he sets haphazard conflicts - against consensus, incessant struggle. There is and can be no end to struggle' (1985: 78). However, what he argued for was an eclipse of the 'form of history not history itself' (Foucault, 1972: 14).

It was the rationalizations of 'limit-experience' he questioned. For example, typical of his assumptions about writing historical analysis was this allegation:

I think history has been the object of a curious sacralization. For many intellectuals the distant, uninformed, and conservative respect for history was the simplest way to reconcile their political consciousness and their research or writing activity. Under the sign of the history cross, all discourse became a prayer to the god of just causes. (1998: 280)

Megill had argued that 'there is a genuine element of liberation in Foucault's opting for the free play of interpretation rather than the circumscribed work of the interpretation of things' (1979: 503). He did not consider that Foucault could ever be an historian because he was 'not interested in the interpretation of the past'. He wrote in 'myths', Megill suggests, that bear no relationship to anything that actually happened in the past. Nonetheless, reflecting something of the typical critical 'indecision' about him Megill still concludes that 'if Foucault should not be taken seriously as a historian, he most 
emphatically should be taken seriously as an indication of where history now stands' (1979: 502, emphasis in original).

Foucault continues to cast a long shadow over these research methodologies that arise out of his analyses of power/knowledge (c.f., McGowen, 1994). He rejected the idea that history is the complete record of a reliable narrative that only remained to be discovered, interpreted and explained (c.f., Murphy, 1984; Poster, 1982). He suggested that explanation 'would be the bad epistemological model; understanding is the mythical figure of a human science restored to its radical meaning in exegesis' (1998: 257-8). Such an approach to historical knowledge, he contended, 'rather than opening onto the truth of the world, is deeply rooted in the "errors" of life' (1998: 477). He famously clashed with the French historians - long before their English counterparts joined the 'fray' - about how elusive was the notion of society (c.f., Noiriel, 1994). As Noiriel argued, Foucault's 'general theme is not society but the discourse of the true and the false' (1994: 549).

His claim to be a new 'historian of the true' - while simultaneously attacking the historian's ability ever to know the true - for some historians was not only methodological nonsense but also a stunning piece of arrogance. He was 'less concerned with being faithful to a source of authority than with working within a certain ethos of enquiry, with fabricating some conceptual tools that can be set to work in relation to the particular questions that trouble contemporary thought and politics' (Rose, 1999: 5). As a result, he has sometimes been described as more a 'wild romantic' than a measured and responsible historian (c.f., Megill, 1979; Merquior, 1985)!

Others, less certain of their ability to dismiss him, suggested that 'there is a transformational system built into Foucault's conception of the succession of forms of the human sciences, even though Foucault appears not to know that it is there' (White, 1973: 45). Rorty has similarly argued that Descombes' depiction of the differences between an 'American' and a 'French' Foucault xlii suggests a particular tension in Foucault's thought - 'characteristic of the Romantic intellectual who is also a citizen of a democratic society' (1990:1). Moral tension between radical respect for others and the search for individual autonomy leads inevitably, Rorty suggests, to the process of self- 
invention. He thus dismisses Foucault as an irrelevant Nietzschean 'knight of autonomy'.

It is, nonetheless, precisely this wilful jousting that characterizes Foucault's sense of history. Clearly, Rorty thought him a 'quasi-anarchist' in that he was trying to 'envisage a society as free of its historical past as the Romantic intellectual hopes to be free of his private past' (1990: 5). And it is this that most enrages those critics whose philosophy of history was grounded in more empirical argument. While Rorty approved of some aspects of Foucault's ideas he also sharply criticized him for failing to provide some 'suggestions about how our children might inhabit a better world in the future'. $\mathrm{He}$ assumed that he gave up on the 'notion of a common human nature', denying a joint subjectivity which might lead to what he called the 'untheoretical sense of social solidarity'. As he continues:

It as if thinkers like Foucault and Lyotard were so afraid of being caught up in one more metanarrative about the fortunes of "the subject" that they cannot bring themselves to say "we" long enough to identify with the culture of the generation to which they belong. (1991: 174)

Clever enough on the face of it but such commentary depends upon a particular discursive assumption that Foucault's intent was fundamentally to explicate a 'rapport à soi' - an ethics of the self, alone (Nehamas, 1998: 180 ff.; Aladjem, 1996: 295). Rorty can reject the notion of the textual 'we' in Foucault, as Foucault equally rejected the earlier invitation from Rorty to be part of a liberal political 'we' (1984f: 385)! Nonetheless, Foucault's efforts were not simply an expression of 'himself in the present' - his writings often referred to 'ourselves in the present'; by implication a 'we' and not essentially an 'l' totally alone.

While often a solitary he was, as we have seen, preoccupied with the issues of the excluded and disposed. He was at pains to recognize the unique culture of his generation albeit that he could comment that it was a 'time like any other, or rather a time which is never quite like any other' (Raulet, 1983: 206). What he rejected was not the idea of cultural uniqueness, or analysis of power of the present, but that kind of rationalizing about the present that relied on certain historically derived discursive patterns - his theme, again, of 'limit-experience'. 
Perhaps the pivotal problem that historians have had with Foucault is that they did not consider his analyses accurate or systematic. He did understand this but chose not to contend within the discursive structures that informed such an opinion of him. As he wrote, his studies:

... are studies of "history" by reason of the domain they deal with and the references they appeal to; but they are not the work of a "historian." Which does not mean that they summarize or synthesize work done by others. Considered from the standpoint of their "pragmatics," they are the record of a long and tentative exercise that needed to be revised and corrected again and again. It was a philosophical exercise. The object was to learn to what extent the effort to think one's own history can free thought from what it silently thinks, and so enable it to think differently. (1985: 9)

What that thinking differently entailed is contained in his reflection on 'certain paradoxes and difficulties, to substitute a history of ethical problematizations based on practices of the self, for a history of systems of morality based, hypothetically, on interdictions' (1985: 13). He was not asking the 'historian's question' - the validation of interpretations that depended upon 'systems of morality' which, from his perspective, subsumed the subject within broad analytical sweeps of social and political change. Such analyses were, he argued, based upon systems of 'limits' and 'interdictions' - the complex controls exerted upon the subject (c.f., Gearhart, 1995, 1997). ${ }^{\text {xiii }}$ These controls were indicative of the 'limit-experiences' that he critiqued. What he focused on was the 'microphysics of power' - all the manifold ways in which power (and not Power) was internalized within the discourses of subjectification (c.f., Dean, 1994a). He was always more concerned with how power was refracted into the core 'practices of the self'.

Foucault was quite clear in studying these 'power relations', or what he also termed the 'rationality of dominations', that he was not discussing power as it was manifested in the political processes of interdiction that shaped citizenship requirements and constitutional processes. In his study of power (the rationality of dominations) he looked for 'interconnections that were not isomorphisms'. He was not trying to demystify or explain interconnections in any systematic way, since it was not the exactness of the connection between disparate events that he sought. As he stated:

... when I speak of power relations, of the forms of rationality which can rule and regulate them, I am not referring to Power - with a capital P - dominating and imposing its rationality upon the totality of the social body. In fact, there are power relations. They are multiple; they have different forms, they can be in play in family relations, or within an institution, or an administration - or between a dominating and a dominated class power relations having specific forms of rationality, forms which are common to them, etc. It is a field of analysis and not at all a reference to any unique instance. (Raulet, 1983: 207, my italics) 
He was more concerned to explore the multitude of small ' $p$ ' power relations. This represents his remarkable challenge to orthodox historical analysis that we 'get inside' the functioning of such power relations to see how fundamentally they construe 'thatwhich-is' and delimit 'that-which-might-be'. Studying these power relations did not allow him license to construct a new paradigm of power. As he stated, "I in no way construct a theory of Power. But I wish to know how the reflexivity of the subject and the discourse of truth are linked' (Raulet, 1983: 207). What he was always concerned to reflect was the enduring question he posed himself - 'How can the subject [formed through the rationalizations of 'limit-experience'] tell the truth about itself?'

If we accept that the point of his analysis was to examine the 'way reflexivity of self upon self is established' then we can utilize his critique to re-examine the taken-for-granted 'truths' of separate political hegemonies. He cannot be criticized for not developing a general theory of power or an analysis of power, as it exists now. These were not the tasks he set for himself. Nonetheless, my contention is that there is a radical implication to his analysis that has the capacity to lever the dominance of current neo-liberal political imperatives. The question Foucault leaves with us is whether the 'microphysics of power' - the 'reflexivity of self upon self' - is a more crucial set of inquiries than determining general theories or arguing with current political hegemonies at the point of their obvious strength?

Simply put, his question is an invitation for us to 'think differently' about our how we define present. As he wrote with some obvious personal feeling:

As to those for whom to work hard, to begin and begin again, to attempt and be mistaken, to go back and rework everything from top to bottom, and still find reason to hesitate from one step to the next - as to those, in short, for whom to work in the midst of uncertainty and apprehension is tantamount to failure, all I can say is that clearly we are not from the same planet. (1985: 7)

What then might we make of those initial critics who were so trenchant in their dismissal of Foucault's invitation (c.f., Arac, 1980; Merquior, 1985; Midelfort, 1980; Said, 1972; White, 1973)? A more considered and 'second-wave' of historical reflection about his importance is represented in the recent journal Arcadia which contained papers from an important Zeitschrift für Allegmeine und Vergleichende Literaturwissenschaft on Foucaultian history (c.f., Goldstein, 1998; Korsten, 1998). This collection is a significant reinstatement of Foucault within the field of cultural history (see also Gordon 1990a and 
$1990 \mathrm{~b}$ for an example of this in the reworking of Foucaultian historiography in respect of Madness and Civilization).

Veyne's defence of Foucault's use of history, in relation to the 'problem' that he has posed for those historians still imbued with discovering the 'true' past is instructive. It points towards the intellectual divisions within the 'human sciences' that his genealogical critique of the 'history' of power/knowledge functions 'in the present' was specifically aimed at dispelling. ${ }^{x i v}$ As Veyne argues:

Sociology is born and lives on he incompleteness of history; when it is not an empty phraseology, it is contemporary history or comparative history without the name, and good sociology, the one that deserves to be read and is read with interest, is one of those histories. It is therefore proper that historians should be conscious that sociology is history that they neglect to write, and whose absence mutilates what they do write. (1971: 281)

Foucault was constantly preoccupied with this 'tangle of problems' in his depiction of 'limit-experiences' and whether it might be possible to break out of the intellectual straitjackets that 'history' and 'sociology' prescribe in their various definitions about the 'truth' of human experience. His challenge to 'think differently' about the 'facts' of theoretical analysis that historians or sociologists take for granted remains a goad and stumbling block. His analysis of 'limit-experience' and how we are made subject to particular forms of rationalization are insights into the 'truth' of knowledge that are an irritant to those preoccupations about the universality of reason. His efforts to unravel this 'tangle of problems' that preoccupied him may not have been resolved. Nonetheless, his invitation that we should not settle for anything less in our thinking about how we have created the social and political 'truths' that define us is still, for me, an ethical challenge that deserves our full respect.

\section{(3) Foucault: A 'False' Prophet of Power?}

Charles Taylor is one of the principal critics of Foucault's analysis of power/knowledge and set out his own rebuttal. ${ }^{x / v}$ For example, he rejected Foucault's notion of the capillary or ubiquitous notion of power and argued that depicting power as ubiquitous made no sense without also outlining the corollary of liberation from power - hence freedom. He argues that capillary and ubiquitous power (such as Foucault depicts) requires 'disguises and masks' and determinedly proceeds by way of 'falsehoods'. As he outlined: 
If some external situation or agency wreaks some change in me which in no way lies athwart some such desire/purpose/aspiration/interest, then there is no call to speak of an exercise of power/domination. (1986: 91)

Taylor's perspective is that analysis of power is ineluctably tied to the mutuality of 'imposition/liberation': to the very notion of agency that Foucault questions - who preferred to discuss 'relations of power'. Any idea of power as 'imposition', without a corresponding analysis of the possibility of 'liberation' equates to 'illusion', Taylor thought, and to 'speak of power and to want to deny a place to 'liberation' and 'truth', as well as the link between them, is to speak incoherently' (1986: 93). We can see how Taylor impresses his own interpretive patterning. His criticism is constrained within the patterns of his analysis since he cannot see outside of the interpretative structure of power that he constructed and has foisted onto Foucault (c.f., Patton, 1989). It is this equation and patterning of ideas that forms the substance of the attack on Foucault as nihilistic. This is to utilize a precursive set of analyses that restrict and constrain an understanding of Foucault. Given that this is the 'representative' strand of the criticism of Foucault's presumed ultimate nihilism - what are we to make of it?

The first point is that the intent and process of such criticism regards 'truth' as having a releasing or, more explicitly, some kind of redemptive force. Consequently, the patterned ground of such critical scrutiny is that 'truth' is release from - an aspect of redemption - and not an examination of any accurate observation of the processes of power. Such criticisms of Foucault seem unable to deal with his 'philosophy of the present' where he suggests that:

Nothing is more foreign to me than the idea that philosophy strayed at a certain moment of time, and that it has forgotten something and that somewhere in her history there exists a principle, a basis that must be rediscovered. (1987: 125)

What he challenged was any notion of power that could imply the containing or incubation of a transcendent stance. He argued that his analyses of the 'games of truth' were not concealed or implicit 'relationships of power'. He thought this interpretation 'a terrible caricature' (1987:127).

Against the flurry of such criticism that labels him a relativist and even nihilist are the valuable insights of Maslan who suggests that 'the argument for Foucault is finally not a theoretical argument against political action, but a pragmatist argument against theory' (1988: 96). His notion of transgression in 'limit-experience' clearly set out his argument 
for resistance to local exercises of power. There was, for him, sufficient opportunity for resistance in the present. He did not need any notion of a 'free space' where there were no effects of power, or more properly an arena in which 'relations of power' were curtailed so that 'freedom' might be. What he attacked was 'the remnants of holistic, metaphysical assumptions in other social theories' (1981: 61-62).

Even though he relinquished all forms of argument that relied on the notion of universal progress that did not mean that his ideas had no relevance to emancipation or that he could be dismissed as a relativist with no ethical gravitas. For example, the question how to resist the 'universal reign of the normative' was something that preoccupied him until the end of his life. It is an intrinsic aspect of the 'tangle of problems' that he was not able to resolve but which expressed his sense of how these processes created limitexperiences' that defined, construed and controlled what was possible. As he argued:

These relations of power are then changeable, reversible and unstable. One must observe also that there cannot be relations of power unless the subjects are free. If one or the other were completely at the disposition of the other and became his thing, an object on which he can exercise an infinite and unlimited violence, then there would not be relations of power. In order to exercise a relation of power, there must be on both sides at least a certain form of liberty ... That means in the relations of power, there is necessarily the possibility of resistance, for if there were no possibility of resistance - of violent resistance, of escape, of ruse, of strategies that reverse the situation - there would be no relations of power. This being the general form, I refuse to answer the question that I am often asked: "but if power is everywhere, then there is no liberty." (1987: 123)

His notion of 'freedom' was thus contained within his depiction of power - something that Taylor as an exemplar of such criticism completely misunderstands. This exposes the difficulty in trying to 'locate' Foucault by tying him to a periodization of his ideas. In his later writings he does seem to have shifted his ground about the possibility of an 'aesthetics of freedom' in order to convey 'the liberating effect of thinking the history of one's own truth' (Flynn, 1985: 539; c.f., Huijer, 1999).

In his analysis of power Foucault set out three separate levels - 'strategic relationships', 'techniques of government', and 'levels of domination'. As he stated:

... we must distinguish the relationships of power as strategic games between liberties strategic games that result in the fact that some people try to determine the conduct of others - and the states of domination, which are what we ordinarily call power. And, between the two, between the games of power and the states of domination, you have governmental technologies. (1987: 130) 
Not only did he refashion the ground on which such debates about power and freedom took place, but he also challenged the role of the dispassionate social critic. Perhaps it is this rupture with the implicit 'hope' of freedom that so angers Foucault's normative critics? For example, in addition to arguing that he is a relativist and has no grounds for fight or resistance to countervailing power is the variant that his arguments are too general, and his analyses too ubiquitous. This position holds that 'while appearing to criticise everything ... [Foucault] reduces everything to a single dimension, and ends up criticising nothing' (Ray, 1988: 101; c.f., Freundlieb, 1988; Philp, 1983; Wartenberg, 1984). Another common criticism was that he proffered no rational grounds for deciding between theories, options, programmes, moral views or political goals. While it was suggested that 'he could not theorise such choices other than [as] a clash of subjectivities', such arguments deliberately avoid Foucault's ethical reasons in his thesis of 'limit-experience' for wanting to expose such grand philosophical meta-narratives (Ray, 1988: 101).

It is hard to see how such assumptions about his inability to 'see' any aspect of human liberation can be sustained if we are to respect the integrity of his own arguments. Maslan, for example, suggests that to believe that Foucault removes the possibility of genuine resistance is 'to believe that the only kind of freedom worth having is not freedom to act as one chooses, but freedom from the limits of action itself' (1988: 98). It is true that he was 'a little distrustful of the general theme of liberation'. He feared that using such ideas loosely increased the possibility that recourse would again be made to some essentialist arguments for a pre-existing human foundation. While his notion of transgression and 'limit-experience' assumes that challenges to the various systems of power do require 'conflict, confrontation, struggle, resistance' (c.f., Tully, 1999a) he would never allow his ideas to serve as a programme for progressive political action. He saw such assumptions as seductive 'bolt-holes', always to be vigorously avoided. His analysis of the 'omnipresence of power relations' suggested that 'an account of power relations is sufficient for social explanations' (Lynch, 1998: 68).

What he argued was that conflict should be made more 'visible' and that this was of greater significance than simply engaging in yet one more polemical debate. He thought it more valuable to understand the forms of rationalization and that this was more radical and revealing than some transcendental stance that sought to ascertain some 
precursive and therefore compelling truth. He rejected any alignment of his ideas with any such essentialist perspectives and contended that no valid analysis of liberation could ever proceed from the assumption that 'truth' be seen as 'concealed, alienated or imprisoned in and by some repressive mechanism' (1987: 113). It was from an investigation of 'our present', he contended, and not from any reliance on a transcendental or essentialist past that 'new power relation[s] must emerge, whose first, temporary expression will be a reform' (1988f: 155-156).

Foucault's notion of the subject, shaped by the normalizations and subjectifications of 'limit-experiences', 'does provide a basis on which to understand the inevitability of resistance to domination' (Patton, 1994, 61). Connolly similarly argued that Foucault, following Nietzsche, did set out the ground for a 'politicization of an ethical sensibility' (1993b: $141 \mathrm{ff}$.$) . It was this that so many of his critics failed properly to consider.$ Foucault's 'problem' was not that he was required to formulate 'the moral norms that accord with our present moral constitution but rather the Nietzschean problem of suggesting ways in which we might become other than what we are' (Patton, 1994: 71).

Connolly's description of what such a 'post-Nietzschean ethical sensibility' might entail echoes Foucault's description of the elements of 'limit-experience'. He outlines four aspects to such a sensibility. It would 'expose artifice in hegemonic identities and the definitions of otherness ... through which they propel their self-certainty'. It would 'destabilize codes of moral order within which prevailing identities are set' and reveal how crucial was resentment in 'these constructions of difference'. It would attempt to 'cultivate generosity' in polemical contests by pointing to their inevitability and the consequent requirement to respect the other - what Connolly, echoing Nietzsche, termed a 'pathos of distance'. Finally such a sensibility would seek to implement what Foucault tried himself to do which was to 'contest moral visions that suppress the constructed, contingent, relational character of identity with a positive alternative that goes some distance in specifying the ideal of political life inspiring it' (c.f., Connolly, 1993b). Foucault's concept of power, and how it might be analyzed, was more wideranging than any specific expression of power simply defined as malign or dominating. This is hardly an ethical position that has no normative gravitas or agency! 


\section{Sociology and Theories of the State: Did Foucault Have One?}

The 'problem' for anyone attempting to apply Foucault's work as commentary on the State is that he does not ontologise power, or discuss the State in the way that sociologists usually do. Instead of 'addressing the State as a theoretical problem, he approaches it through the perspective of the practices and rationalities that compose the means and rule of government' (Dean, 1994a: 153). As Osborne argued, 'the raison d'être of the concept of governmentality really centres on the need to find a concept that will not reduce the question of power to that specifically of public power, and above all the State' (1998b: 133). Perhaps his famous use of Nietzsche's dictum that the 'state is the coldest of all cold monsters' has forced a false construction of the historical tension he criticized? Consider, for example his conclusion to Omnes et Singulatim:

For several centuries, the state has been one of the most remarkable, one of the most redoubtable, forms of human government. Very significantly, political criticism has reproached the state with being simultaneously a factor for individualisation and a totalitarian principle. Just to look at nascent rationality, just to see what its first policing project was, makes it clear that, right from the start, the state is both individualising and totalitarian. Opposing the individual and his interests to it is just as hazardous as opposing it with the community and its requirements. (1981b: 254, my italics)

This brings any examination of Foucault's relevance to social theorizing sharply up against his own expressed purposes where he sought to 'study power, not starting from the primitive terms of relation, civil subject, State, law, sovereign, and so on, but starting from relation itself' (Veyne, 1997: 111). Such an examination of the present has proven difficult given the widespread reification of the past within the analytical structures of contemporary critical theory. Nonetheless, despite his clear 'reservations' about the applicability of Foucault in relation to social theory Osborne offers one of the more useful threads of how Foucault may yet be used to do precisely this! Foucault, he suggests, has presented the clearest argument for why we should escape from the:

... blackmail of being for or against the enlightenment, for or against modernity; not least in order to resurrect for today's conditions some of the principles of the enlightenment as ethos. Enlightenment is not a doctrine but an attitude, the will to keep ourselves on the move, to find a way out of our predicaments ... enlightenment would be as much the object as the medium of such an attitude. (1998b: 136)

Foucault argues that relying on reason itself to challenge the processes of subjectification and normalization has proven ineffective because 'the field [of his investigations] has nothing to do with guilt or innocence' (c.f., Bernauer, 1988). It is senseless, he continues, 'to refer to 'reason' as the contrary entity to no-reason'. $\mathrm{He}$ has no interest in the binary 'games' of any academic argument that sought to 
apportion guilt or expound on innocence. The 'morality' of reason is, for Foucault, an implicit aspect of the discourse of reason - it is better seen as 'experience' and not the 'truth'. He saw 'his own project as "the eclipse" of this philosophy of interiority', one that under-pinned the idea of the 'morality of reason' (Lilly, 1991: 145).

Foucault was neither for the one or the many. His was a more radical intent - to examine the processes of rationalization that constructed what we mean when we say 'Omnes' or 'Singulatim'. That important paper (1981b) is his reflection on how 'philosophy ... might keep watch over the excessive powers of political rationality which is rather a promising life expectancy' (1981b: 225, my italics). Keeping watch over the 'excessive powers of political rationality' may indeed be banal, as he states, but in the phrase 'a promising life expectancy' he intends that we discover 'which specific and perhaps original problems are connected with' such banalities. The radical possibility that such challenges pose to current political orthodoxies does not evacuate or eviscerate the social. What it does is call into question the 'Social' - the "Whole of Society" - as a paramount reality within which we do our social thinking. It reopens the classic Kantian question (c.f., Parsons, 1988) - 'For what may we hope?' The emotional force that lies behind such analyses is revealed in Foucault's next assertion:

The relationship between rationalisation and the excesses of political power is evident. And we should not need to wait for bureaucracy or concentration camps to recognise the existence of such relations. But the problem is: what to do with such an evident fact? (1981b: 226)

The question he poses is whether we can ever resolve the distinction between the 'one and the many'? Paraphrasing Hacking, I contend that while Foucault might argue that the society as a whole is a fraud that is not to say that society and the social is nothing. For Foucault, the 'residual and enduring demand of these discourses is not to think without man but to rethink the question of man within a post-metaphysical ontology' (Burke, 1992: 114, my italics).

If we were ever able to distil his arguments into one particular statement - an obvious absurdity - it might just be that it is encapsulated in that expressed desire to know what kinds of rationality people caught up in systems of power are using. Certainly it represents the core of his 'tangle of problems' where he probed the 'relationship between limit-experience and the history of truth' (Foucault, 1991d: 71). As Maslan argued, the 'inherence of power is not the destruction of truth or freedom, but instead the 
inherence of practice' (1988: 110). The rationale for these 'searches' into the practices of power reflect aspects of Veyne's aphorism that 'there comes a moment, in the evolution of ideas, when old problems are basically liquidated, even if we go on speaking of them out of habit' (1971: 289). Foucault's dispute with traditional sociological investigations is that they restrict analyses of power to the themes and mechanisms of exchange, production and communication. These investigations start from a set of reflective 'givens' he rejects. His investigations into the excesses of power led him in very different directions, particularly to posit his theory of governmentality that we willingly submit to being governed (c.f., Free, 1993; McWhorter, 1994).

\section{Reformulating Social Theory: Hints Nuances, Paradoxes - Insights?}

Defending the possibility of '/a société' is a set of assumptions not often associated with Foucault, but simply arguing that he really had no 'politics' at all (Cohen, 1988: 87; c.f., Ray, 1988), as did his early polemicists, is a reductionist misreading of his work. It is easy to assume that any 'valid' critique must necessarily propose answers. What prompted such conclusions is Foucault's deliberate blurring of some of the 'boundaries' between ideas that were normally differently described in social theory. For example, as Bevir argues, many 'of the difficulties, but also some of the excitement, of Foucault's work, derive ... from his characteristic elision of the distinction between autonomy and agency' (1999: 68). If this distinction could really be collapsed then it makes possible a new ethics 'that would have no recourse to religious, transcendental or scientific truths' (Osborne, 1994: 487). The rationale for political action would arise out of the practices of how we defend our choices, disbursements, and social arrangements. They would not be defended by recourse to something that is immutably a priori. We made it so, not God, is Foucault's constant injunction to critical reflection.

Foucault abandoned such thinking because he concluded that the 'main problem when people try to rationalise something is not to investigate whether or not they conform to principles of rationality, but to discover what kinds of rationality they are using (1981b: 226, my italics). Understanding his defence of such an orientation to social theory making is fundamental to any grasp of his purposes. It sets up the rationale for his research methodology. He was not interested in discussing compliance to reason but rather capturing and revealing the processes and 'sites' of rationality. He even thought the word 'rationalization' to be dangerous. 
The distinction he makes here is crucial. He is not interested in 'conforming' or 'fitting' his ideas within the given structures of Enlightenment reason - nor did he seek to associate them with any classical sociological themes - he wanted rather to know what kinds of rationality are being used. Following out the implications of his concept of "limitexperience' he thought that revealing the form and practices of rationality was a more productive strategy. It led to an analysis of the practices of power and thus confronted all such assumptions with their contingency and their practical rather than their ideological and normative intent.

The inevitable focus of his investigations into those mechanisms and discourses that normalize, dominate and fashion the disciplinary society provoked a certain orientation to state power. It was this denial that there could be any intellectual 'havens' in our reflections on modernity that led Foucault to some conclusions that appeared irresolvable and despairing. For example, he said society as a whole 'is precisely that which should not be considered except as something to be destroyed. And then, we can only hope it will never exist again' (Bouchard, 1977: 233). This is often seen as his bleakest 'social' message, even by his quite articulate defenders who stumbled over its intent (c.f., Hiley, 1988). Nonetheless, as I have argued, he never lost 'a certain loving despair over the fate of people whose past offers little reason to forget the omnipresence of barbarism as the underside not only of our cultural monuments but [also] of our everyday institutions and rhetorics' (Bové, 1988: xxxiv). While he was preoccupied with the destructive aspects of modernity he still asserted ' do not conduct my analyses in order to say: this is how things are, look how trapped you are. I say certain things only to the extent to which I see them as capable of permitting the transformation of reality' (1991d: 174).

\section{Rationalizations and 'Limits': Foucault's Challenge to Power}

In his 1979 lectures Omnes et Singulatim he presented the clearest explanation for his unique approach to the study of power. He argued that:

Our civilisation has developed the most complex system of knowledge, the most sophisticated structures of power: what has this kind of knowledge, this type of power made of us? In what way are those fundamental experiences of madness, suffering, death, crime, desire, individuality connected, even if we are not aware of it, with knowledge and power? I am sure I'I never get the answer; but that does not mean that we don't have to ask the question. (1981: 239-240, my italics) 
The question though was very important and reflected his attack on Enlightenment assumptions that modernity had solved those 'fundamental experiences of madness, suffering, death, crime, desire, [and] individuality'. Foucault was despairing of much critical opinion that he saw as sterile and banal. He wanted to step outside the frozen rhetoric that oscillated between an elucidation of reason's ability to reflect the 'truth', and various arguments for a normative curb on excessive political rationality. His assertion that he may 'never get the answer' emerged from his assumption that there is nothing 'given', no transcendent teleological intent, in the patterns and practices of our politics. Extending this thesis, Hacking presents Foucault's core belief as follows: 'every way in which I can think of myself as a person and an agent is something that has been constituted within a web of historical events' (1986a: 36, my italics).

There was no possibility, Foucault argued, to define the self as possessing some innate intuitiveness that could locate some personal sense of meaning outside of historical events. It reflects aspects of Elias' assumption that civilization was 'a process of shifting powerful and disturbing emotions and experiences, such as sadism and violence, from the centre to the borderlines of society' (Alford, 2000: 139. There, he contends, 'they are not lessened or mitigated, but contained and stored up in behind the scenes, in military barracks, police stations, and prisons, ready to be called upon in times of unrest, and exerting a continuous threat to those who would challenge the regime' (2000: 139).

The relationship between rationalization and the excesses of political power seemed self-evident to Foucault. To continue to challenge it from within the discursive rationalizations of contemporary criticism did not provide him with sufficient answers to his impelling question about 'what has this kind of knowledge, this type of power made of us?' His 'problem', as he stated it, was to deal:

... with the relations between experiences (like madness, illness, transgression of laws, sexuality, self-identity) knowledge (like psychiatry, medicine, criminology, sexology, psychology), and power (such as the power which is wielded in psychiatric and penal institutions, and in all other institutions which deal with individual control). (1981: 239)

This intellectual 'problem' has aroused, as we have seen, so much antipathy and reflected his famous 'elusiveness', and apparent idiosyncrasy, as well as his unwillingness to 'locate' his own criticism within established post-Kantian discursive streams. His unwillingness to 'stand' explicitly within processes of intentional critical opinion, and even to pose the possibility of a different discourse (in effect, a plague on 
all your houses), has earned, as we have seen, some scornful rejection within sociology (c.f., Osborne, 1994; Fox, 1998). Effectively, the 'problem' that he posed to sociology is that he would not support 'the fundamental claim of sociology ... to have captured the historical moment embodied' in Polanyi's depiction of the Great Transformation (Dean, 1994a: 7). Osborne considered that Foucault's dismissal of the notion of the 'State', as a specific problem of research, was sufficient reason to reject his relevance to sociology (1998b: 133).

Foucault would not agree that the tools of sociological analysis that set out to describe the transforming aspects of modernity could ever be seen to transcend historical particularity. His genealogical emphasis on the mass of contradictory data that we must draw on to understand the structure of our 'limit-experiences' led him to critique the methodological theories that sociology and history developed to validate their separate research activities. Both the generalizing ('nomothetic') processes of sociology as well as the 'idiographic' processes of historical reflection that concentrated on what was specific and singular (c.f., Dean, 1994a: 7 ff.) drew his ire.

However, the very same unwillingness to pose a new methodological paradigm has

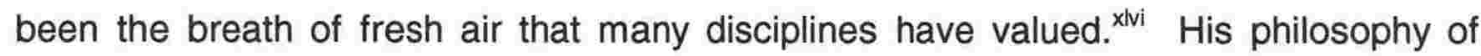
history, his factual accuracy, his prose, his unwillingness to clearly and accurately reference his sources, his wilful and capricious reworking of linguistic meanings, his fanciful notions of caesura, all of this and more form the substance of the attack on his ideas. That these sets of criticism can be grouped into patterns provides a reflexive view of the nature of contemporary critical theory. However, all these negative assessments that he was ultimately a relativist do not really vitiate his importance. He did challenge the structure of hermeneutics which he saw as trapping 'us into playing the arbitrary and boring part of either the rationalist or the irrationalist', but we have much to gain from respecting and applying that challenge (1981: 226). He did not want to be drawn inexorably into a defence of reason and freedom as such. Nor did he see much point in defending the specific epistolary or normative truth of any one specific text. He argued that many intellectuals maintained:

... against all probability, a conception of history organized on the model of the narrative as a great sequence of events taken up in a hierarchy of determinations: individuals are caught within that totality which transcends them and trifles with them, but of which they are perhaps at the same time the unwitting authors. So that for some people, this history, 
both an individual project and a totality, became untouchable; to refuse that form of historical assertion (dire) would be to attack the great cause of the revolution. (1998: 280)

\section{Being 'Submitted to Government'}

In an increasingly packaged time (a time of 'spin-doctors' and 'massaged' information) the slogan 'there is no alternative' has been supremely successful in setting the agenda for welfare reform. Neo-liberalism declaims that it alone represents a reliable guide to the future. An aspect of that welfare rhetoric is that no valid form of comprehensive mutual or social obligation (an aspect of the former welfare state) will again be possible (c.f., Barry, Osborne and Rose, 1993; Burchell, G. 1993; Burchell, D, 1996; Hindess, 1996a, 1996b; Pratt, 1997; Rose, 1996a, 1996b). The social follies of 'welfarism' are presented as an awkward and impossible aberration - individualism is prized and privileged as the pre-eminently rational political state.

Foucault argued that power was always contingent and that there was no easy way to recognize what was progressive or harmful, certainly not at the rhetorical level, and that we have no clear way of knowing what may emerge. He thought it important to see how restrictive such arguments are and how they constrain debate to some transcendent, implicit or teleological presupposition. The 'ought' they express comes from the past even when it alludes to the future. This is the reason for his profound criticism of such ideas. For him, these arguments inevitably fail because they are sustained by the very patterns of thought they seek to criticize. They do not take into account that the normative 'ought' is really only an obverse of what is.

Spinning the cycle of such arguments simply exchanges one form of domination for another - part of the serried system of dominations that we need to understand in respect of social policy theory and various welfare practices. Foucault re-interpreted the use of reason that 'justified' such normalizations and asked much larger questions. To 'see' his larger purpose allows for a different view of the 'social'. What manner of society might we create if we allow for the possibility of a radical contingency such as he envisions? The assertion that this is necessarily and essentially nihilistic and anarchic misses the larger perspective in Foucault for, ironically, in challenging us to understand the forms of rationality that shape our present he 'invites not anarchy but another view of individuality' (Hooke, 1987: 58). It also ignores the possibility of a complex mix of internal and external beliefs; for example, as Hacking argued, those 'who accuse him of 
nihilism fail to see that one can be extrinsically metamoral and intrinsically moral at the same time, or at least, in the same person' (1989: 361).

\section{Foucault: The Imaginative Nomad}

Sociology was not able to secure sufficient 'purchase' on the intellectual nomadism that was Foucault's style. Social philosophers like Habermas 'complained' that his thought establishes no reliable ground for any progressive view of politics let alone develop any normative method that might lead us anywhere. For Foucault, of course, this simply reflected his intention. Empirical historians (like Megill, Merquior and Midelfort) have disparaged and dismissed his 'cultural history', ruing the odd admixture of fact and literature. All three disciplines have struggled to 'make sense' out of his complex theories about power. In all three we can find echoes that Foucault 'ought' to have brought his ideas to some conclusion; that he ought to have established a bastion of a paradigmatic method that could be clearly rejected or alternatively relied on. However, as Patton concluded, Foucault's 'work neither approaches nor sought completion. It is rather a patchwork of studies which when viewed from a distance may produce a pattern' (1984/5: 78).

We may now more clearly see that the patchwork of studies demonstrates a consistent theme in his writing to challenge the 'knowledge politics' of those who would dissect and locate him within their own descriptive reflections. He did seek to explain the constructs that underpin specific assumptions and contentions in order that we might better understand how these individual or localized meanings become reified into obvious and immutable 'truths'. Inevitably, the search for such 'anonymous rules' led him to question the centrality of those assumptions that magisterially stood above patterns of particular discourse and pronounced judgement about them. His self-defined task was to reveal the limitations of such super-ordinate commentary and he somewhat caustically acknowledged that doing so would be 'unpleasant' to those 'used to seeing [the intent of their ideas], in all its pure transparency, [as] the expression of genius and freedom' (1972: 210). Undercutting reliance on any triumphant sense of human wisdom remains his most contentious legacy. The specific elusiveness of his ideas mirrors his fundamental criticism of the 'certainties' of the 'universal intellectual' 
That he could so often be depicted as an anti-humanist reflects a wilful disregard of his own personal political commitments as well as a deliberate misreading of what he wrote (c.f., Patton, 1994; Gandal, 1986; Moussa and Scapp, 1996). Said is much closer to the mark (1991: 10). Foucault rejected the discourse of 'Man', not the nature of human subjectivity. How persuasive can such negative assumptions be when confronted with his own stated intent? For example, he thought that 'one of the most harmful habits in contemporary thought' was to analyze the present applying such discursive descriptors as 'high point', or 'completion' or 'a returning dawn':

The solemnity with which everyone who engages in philosophical discourse reflects on his own time strikes me as a flaw. I can say so all the more firmly since it is something I have done myself; and since, in someone like Nietzsche, we find this incessantly - or, at least, insistently enough. I think we should have the modesty to say to ourselves that, on the other hand, the time we live in is not the unique or fundamental or irruptive point in history where everything is completed and begun again. We must also have the modesty to say, on the other hand, that - even without this solemnity - the time we live in is very interesting; it needs to be analyzed and broken down, and that we would do well to ask ourselves, "What is the nature of our present?" I wonder if one of the great roles of philosophical thought since the Kantian "Was ist Aufklärung?" might not be characterized by saying that the task of philosophy is to describe the nature of the present, and of "ourselves in the present." With the proviso that we do not allow ourselves the facile, rather theatrical declaration that this moment in which we exist is one of total perdition, in the abyss of darkness, or a triumphant daybreak, etc. It is a time like any other, or rather, a time which is never quite like any other. (Raulet, 1983: 206)

Foucault is clearly skewering the logic of intellectual pretence. He could see no point in the great narratives of Hegelian 'thesis, antithesis, synthesis'. Our particular point of history does not arise out of any sense of progression or historical inevitability. It can never be seen, he argued, as a 'unique or fundamental or irruptive point'.

Instead of the 'grand' Kantian question about the nature of our reason he preferred to ask 'what is our present?' That is such an enlightening question if we will allow ourselves to consider the full import of his contention. As Hacking suggests, 'optimism, pessimism, nihilism, and the like are all concepts that make sense only within the idea of a transcendent or enduring subject' (1981: 37). In order to sustain this argument Foucault did rail against the notion of the infinite. He argued that following Kant 'there is a reversal: the problem of man will be raised as a kind of cast shadow, but this will not be in terms of the infinite or the truth. Since Kant, the infinite is no longer given, there is no longer anything but finitude' (1998: 257). He rejected any reliance on those reifications that supported the idea of 'Man' intrinsic to sociology's depiction of the major transformations involved in the history of 'Man'. 
Defending historical 'truth' in tight exegeses about the validity of specific or polemical arguments he saw as vain and misguided. He thought this an empty or mistaken isomorphism that reinforced the very discursive patterns he criticized. It was more important, he argued, 'to refer to more remote processes if we want to understand how we have been trapped in our own history' (1981: 226). His thesis about 'limit-experience' defined our entrapment in particular discourses. He argued that our forms of rationality 'reside on a base of human practice and human history; and that since these things have been made, they can be unmade, as long as we know how it was that they were made' (Raulet, 1983: 206). Reminding us that we have constructed a 'hierarchy of determinations' and that we are the 'authors', even unwittingly, of our assumptions about history is not a debunking but an ethical task of the imagination. That is a manifesto, of sorts, for responsible ethical freedom - it is not just to know the carceral 'walls' but to seek to unmake them as well!

Setting out the various 'Foucaults', previously, established the grounds for why I think he can be used to clarify the competing discourses of welfare and social policy theory. Entering far into the thought-world of a man who wrote 'in order to have no face' poses its own unique difficulties. Nonetheless, in our current reflections about the conflictual world of social policy analysis his ideas 'fit' our perceptions about the troubled certainties of our particular politics. Goldstein summed this up well. She suggested there is something in Foucault's very unsettled nature - his famous changes of mind; his alterations between an icily cold, critical eye and shows of passion, between disdain for our old, self-deceptive liberal humanism and attachment to it - that fits the unsettled world' (1994: 15). Locking horns with him on specific semantics or methodology misses the point. His method was deliberately more inclusive - but he refused to synthesize knowledge into a new 'frozen' paradigm.

What Foucault would not do was apply the tools of the past, as he saw them, to articulate what freedom might mean in the present. It is also too easy to misinterpret his complex debates about a possible 'technology of the self' - often termed the later Foucault - as intrinsically antihuman. His position is that there is no true self to discover and that our ethical task, therefore, involves 'self-creation' and 'self-enlargement' (an examination of the history of our present) rather than 'self-knowledge' and 'purification' (an examination and judging of our present through the received 'wisdom' of the past). 
While he is sometimes quite critical of Foucault, Edward Said is able to set the flurry of this particular criticism - that such assumptions 'proved' Foucault has no concern for collective human experience - in context. As he suggested, Foucault's:

... great critical contribution was to dissolve the anthropological models of identity and subjecthood underlying research in the humanistic and social sciences. Instead of seeing everything emanating either from a sort of unchanging Cartesian ego, or a heroic solitary artist, Foucault proposed the much juster notion that all work, like social life itself, is collective. (1991: 10)

Foucault was well aware how disconcerting and irritating such an approach to the study of knowledge might be. He recognized that considering the study of discourses not as expressions of 'gentle, silent intimate consciousness' but as indicating 'an obscure set of anonymous rules' would provoke an angry disdain, particularly from sociologists. $\mathrm{He}$ was more interested to understand the rationalizations that formed ideas independently of the subject who articulated them. Hence his incidental delight in the overall patterns of the attempts to 'locate' him politically and philosophically. It may be that his politics is more transparent than it seems. As Rorty has suggested, 'Foucault was trying to serve human liberty, but he was also, in the interest of his personal autonomy, trying to be a faceless, rootless, homeless stranger to humanity and history' (1990: 4).

\section{Conclusion}

Given such a radical challenge to academic orthodoxies it is little wonder that Foucault, as well as his ideas, 'resists' the typical processes of academic classification. He looked at oddities, the excluded and occluded, in his search for the "ensemble of relations which maintain themselves and transform themselves independently of the things they connect' (Major-Poetzl, 1983: 10). He described possibilities rather than conclusions for he argued that 'nothing is fundamental'. There is only, for Foucault, the interplay of 'reciprocal relations' and how we connect or maintain irresolvable gaps (1989: 267). He denied any legitimacy to the possibility of a 'grand narrative'. Such narratives always take us away from the present and make of our present something that can only be understood in relation to that which had preceded it. It is an indication of his enduring, but troublesome, importance in the Western history of ideas that there have been so many inconclusive attempts, both during his lifetime (and subsequently), to situate him, as he said, 'in most of the squares on the political checkerboard'. The dilemma of 'What Was Foucaule remains (c.f., Hoy, 1991). 
Where he is located often results from his ability, to offend or scandalize certain critical canons that reify the Western history of ideas into a search for freedom and truth. The difficulty that he poses still to English and American philosophy (and historical theory) reflects something of the great 'divide' between French and English thought (c.f., Rorty, 1982, 1991). While there have been many attempts to 'locate' and 'explain' Foucault generically, the more informed academic critique of him follows a narrower binary pattern (c.f., Fraser, 1989; Patton, 1994). He is vilified for providing no basis for the assessment and analysis of coercive power on the one hand, thus denying the possibility of searching for any 'alternative ideal' on the other. The pattern of this binary criticism - the moral 'search for truth' resulting in normative and imperative obligations seems to have become almost canonical within critical theory. That this was not his explicit intent is ignored. It was precisely this reliance on the 'documents' and 'texts' that support the Western intellectual tradition that he questioned. Indeed this stance has been so trenchantly criticized that attacking him, while simultaneously rejecting the 'excesses' and 'posturing' of late modernity, has become almost a canard of contemporary criticism (c.f., Connolly, 1993b). On the other hand, for some, defending him has taken on all the aspects of a 'noble cause' (c.f., Halperin, 1995).

I have not intended such a defence - after all he needs no such hagiography. He does, however, merit respect for the integrity of what he set out to do. As we have seen in the previous chapter, much of the criticism of Foucault is reflexive of the specific critic's own presuppositions. Any attempt to remove the subjective critical mind from its pivotal reflective role in history is likely to cause offence. The axiomatic assumption of his nihilism and the assertion that he is, in some ways, Nietzsche's more limited 'clone' is derisory (c.f., Rorty, 1990). Even when the criticism of him is substantial it still fails to take into account the overall ethical import of his writing. The following is surely not the prose or intent of a committed nihilist or relativist:

I can't help but dream of a kind of criticism that would try not to judge but to bring an oeuvre, a book, a sentence, an idea to life; it would light fires, watch the grass grow, listen to the wind, and catch the sea foam in the breeze and scatter it. It would multiply not judgments but signs of existence; it would summon them, drag them from their sleep ... l'd like a criticism of scintillating leaps of the imagination. It would not be sovereign or dressed in red. It would bear the lightning of possible storms. (1997c: 323)

How we might, nonetheless, apply some of his ideas to just such a quest for new 'signs of existence' and 'listen to the wind' is the purpose of this inquiry into Foucault's 'social' theory. Things that have been made, not 'given', can be unmade if we understand the 
process of their formation. Seeking to understand the process of how our beliefs are made can be a 'scintillating leap of imagination' - it is surely one legitimate aspect of agency and belief that we try? Such an approach to intellectual inquiry, as Foucault outlines above, is not the 'usual' defence of agency. But there is ethical intent in his 'dream' - ironically not a word often used when commentating on Foucault! It is a dream that implies something of a 'historically grounded belief in the human capacity to transcend limits to the autonomous use and development of human powers' (Patton, 1994: 61). This belief in the possibility of human progress and the transcending of limits is of course, a summary of the great Kantian Enlightenment claim. His dream does reveal itself as an analogue of Kant's famous assertion. It has ethical gravitas but in 'dragging new ideas from their sleep' it has borne, as we have seen, 'the lightning of possible storms'!

Some of the 'storms' and major criticisms of Foucault were surveyed previously to see whether they could be grouped into patterns. Applying something of his own research method to the vast range of critical opinion allowed for an examination of these criticisms as 'practices'; to see what intellectual 'practices' they reflected and to examine what reasoned 'truths' they exemplified. Uniquely, it seems to me, the task is to understand why he should have 'earned' so polarized a reaction. Why his ideas were greeted with such disdain, on the one hand, but with such excitement on the other has been a subtext of this thesis. Perhaps it was his attempt to deconstruct the subjectivity of such arguments into practices that has left so many so angrily defensive because they needed the subjective 'truths he assailed'? He did not regard them as reasoned examples of the enduring 'grand narrative' of freedom in the Western history of ideas: his search for 'freedom' led him in very different directions.

Those tired of such 'empty' grand narratives found in Foucault a new way to see and interpret their theoretical worlds (c.f., Bové, 1988; Cohen, 1985, 1992; Garland, 1997). Nonetheless, he poses some important questions to those commentators who apply his ideas too uncritically and try to bend them too unreflectively to their own theoretical tasks. As Dean contends:

We should be concerned, then, not so much about the recuperation of his work for philosophy, history or the social sciences, than with undertaking a form of analysis concerned with the limits and possibilities of how we have come to think about who we are, what we do, and the present in which we find ourselves. We can use Foucault to form or reform ourselves as philosophers, historians and sociologists, but we can use 
Foucault to inaugurate a critical engagement with our present, with its limits and its practical potential. (1993b: 18)

How we might apply Foucault's work to these tasks suggests requires an examination of a set of questions about how his ideas, particularly his thesis of governmentality, might relate to the development of theory within social policy. This will be an opportunity to think more clearly about the 'limits' and 'possibilities' of welfare practices and various social policy discourses in order effectively to 'inaugurate a critical engagement with our present'. 


\title{
Chapter Six
}

\section{'What matter who's speaking?' - Social Inquiry Following Foucault}

\begin{abstract}
When a society oppresses its citizens in the name of an original spirit of laws, or when a writer masks his opportunism behind a common original "tradition", or conversely, when revolution is derided as the repetition of hopeless utopianism, then in response one can begin again to study, act, write - again. (Said, 1974: 37)

The main point is that the social sciences, if sciences there must be, cannot be a rationalization of natural objects, a body of knowledge for the elite. They presuppose first and foremost a historical analysis of natural objects that is a genealogy, a bringing to light of the practice or discourse in question. (Veyne, 1997: 173)
\end{abstract}

Considering the relevance of Foucault's thought from the perspective of social policy raises two sets of interrelated questions. The first arises in response to his argument about 'limit-experience' that the 'forms of rationality' that determine the rationalizations of current welfare policy and practice are more important in shaping the actual lives of those on welfare than the ideological content of those rationalizations. His thesis about governmentality, for example, set out an argument that social conflicts between the 'one and the many' are structural political dilemmas, intrinsic to rationalizations of the nation state (c.f., van Krieken, 1996). The second develops from his contention that the state is both 'simultaneously a factor of individualisation and a totalitarian principle' (1981b: 254). $\mathrm{He}$ considered that the problems of the welfare state were created by this 'tricky adjustment' where the state is both an instrument of individual rationality while simultaneously expressing a 'totalitarian principle'. This paradox is reflected in the polarized ideological conflicts that swirl around the presumed 'crisis of the welfare state' (c.f., Rose, 1999: 98 ff.), where universal social protection, typical of welfare state dispensations, is no longer deemed affordable.

The strength of that rhetorical crisis undermined general social assumptions that had coalesced around welfare state shibboleths such as social solidarity and mutual obligation. The development of the welfare state may be considered a triumph of classbased and union initiatives, or, alternatively, it can be seen as an outgrowth of the social gospel together with secular humanist claims. Neither of these explanatory mantras, no matter how laudable, adequately encompasses the new governing politics of welfare that replaced citizenship systems of obligation and universal state-mandated provision with 
the logic of markets and the imperatives of consumers. What is expressed in these arguments is a particular 'form' of discourse that reorientates the actual practices of welfare - away from universal welfare states towards targeted welfare societies.

Paul Veyne's point, above, that the social sciences cannot fashion their inquiries solely around a 'rationalization of natural objects' without, thereby, reinforcing existing governing elites echoes Foucault's notion of governmentality. He did not presume that the 'art of government' lay in some pre-existing natural right, or arose out of some superordinate reason, ordained of God (1979b: 7). He rejected the idea that society contained 'a variety of 'natural' processes - to do with economic activity, the development of population, language and morality' (Hindess, 1997a: 267). All of which separately and 'naturally', it might be argued, determined the 'real and unchallenged' ground of political activity. He assumed, to the contrary, that there were no natural objects of 'truth' in any sociological or social policy sense and that we are therefore 'free' to examine even the most stringently applied and apparently effective social and political practices as discourses and 'forms' of rationality.

In this challenge to the 'speaking of the self', and the 'limit-experiences' that define welfare policies, Foucault fashions the grounds for an aesthetic politics (a 'life politics') that has the potential to 'break open' the immanent rationalizations of hegemonic welfare politics. Deleuze suggested that there is a 'vitalism in Foucault' in that his ideas reflected a 'play of forces that operate along a line of life and death that is always folding and unfolding, tracing out the very limit of thought'. Foucault's ideas traced the 'filigrees' of this intersection of life and death. Deleuze commented that Foucault's preoccupation with subjectification (the themes of 'limit-experience') 'amounts essentially to inventing new possibilities of life ... to establishing what one may truly call styles of life: here it's a vitalism rooted in aesthetics' (1995: 91; c.f., Ransom, 1997). As Rose similarly argues:

The suggestion that we might each try to make our own life 'a work of art' was an invitation to creativity and experimentation, not a retreat to consumerized narcissism. This life politics was defined, in part, by what it was not - it was not conducted under the sign of a morality (in the name of a heteronomous moral code), not conducted under the sign of an epistemology (in the name of a hidden truth or desire revealed by knowledge which it was one's aspiration to realize), not conducted under the sign of a regime of authority (subordination to the organizational demands of a party) and not conducted in relation to an absolute end point at some future time (to which the present must be subordinated). Rather than subordinate oneself in the name of an external code, truth, authority or goal, such a politics would operate under a different slogan: each person's life should be its own telos. (1999: 282-283, italics in original) 
However, this critical examination of the processes of rationalization, while it did not preclude public and political contestation, represented no blind rebellion against the status quo. For Foucault argued that simply denouncing institutional power or control was ineffectual (c.f., Pickett, 1996; Schram, 1995; Lemert and Gillian, 1982; O'Connor, 1988). It was not enough, he suggested, simply to 'cast the blame on reason in general'. The pre-eminent question is to discern what form of rationality determines the shape and limits of specific policies (1981b: 254). Foucault applied his genealogical criticisms to reveal the 'fugitive, deniable and contestable experience, always resistant to articulation' of hegemonic politics (Connolly, 1993: 146-147). He was interested in an agonistic process, involved in an assessment of 'limit-experience', which brought to the surface the unacknowledged practices of politics - what Connolly describes as disturbing 'the closure of dogmatic identities'.

What Foucault meant by an agonistic politics involved 'transgressing' the limits of specific rationalizations and subjectifications without falling back upon the tired ideological and polemical struggles of the past. This calls for a 'politics which is itself an active art of living. And it would accord itself the right, perhaps the duty, to oppose all that which blocks or subverts the capacity of others asserting for themselves their own vitalism, their own will to live through the active shaping of their lives' (Rose, 1999: 283). The challenge posed by bio-politics was that social critique ought to examine the form and patterning of political rationalizations and not adjudicate between contending polemics that constantly pressured the language of critique to 'reinstate the fundamental "logic" of good and evil into the experience of being' (Connolly, 1993: 147).

What Foucault offered in his analyses cannot be used as some new form of 'higher' or more effective critique - a new ineluctable polemics, but rather to indicate a 'certain vitalism' that would 'be in favour of life, of 'the obstinate, stubborn and indominatable will to live', of the conditions that make possible the challenge to existing modes of life and the creation of new modes of existence' (Rose, 1999: 283). Arguing from within a particular critical position and disputing polemically with separate ideologies was useless, Foucault thought. Examining the ethic of how we are governed and how we govern others are important tasks of reflection that do not depend on the epistemology of a more explicit political or sociological critique but rather discerns 'the possibilities and the limits for ways of existing that it embodies' (Rose, 1999: 293, my italics). 
Foucault did not go looking into 'what is affirmed and valorized in a society' but rather studied 'what is rejected and excluded' (1998: 335). We cannot assume that the normative enquiry 'what is to be done' can be answered in an application of his genealogical analysis. Foucault's 'politics' provides no legislative programme or prophetic 'edge' since 'it seeks to disrupt rather than to replace one 'regime of truth' with another' (Smart, 1983: 82). Given this intention to disrupt the structure of discourses, and to study the excluded, Beckett's question, 'What matter who's speaking?' does, for Foucault, matter a great deal! xivii

Questioning the idea of 'who's speaking' and what does it matter has been uniquely 'offensive' to those for whom authorship, as such, is a mark of identity or reasoned endeavour (c.f., Burke, 1992; Hollier, 1985; Nehamas, 1986, 1987, 1993). Foucault's unwillingness to be located, to claim a distinctive voice for himself as author, was both personal and contentious. As we have seen, he argued that language cannot reveal reality and that the 'history of words [should be kept] in its proper place'. He did not enjoy the thought of having 'acolytes' and his wanting to remain 'masked' reflects something of his private intent. There is some irony in all of this. That he was deeply hurt by some aspects of his critical acclaim is well attested (c.f., Bernaeur, 1986, 1988; Rybalka, 1985). Whether or not he wished for acolytes his public reception did matter to him (1991d). ${ }^{x \text { viii }}$ As Patton suggests, 'The Order of Things combines an anonymous and objective style of writing with a work which is nevertheless "violently personal"' (1984: 22-23). That personal passion was combined with a public, ironic and elusive style that was equally passionate (c.f., Deleuze, 1995).

Who is actually speaking and how is their 'voice' heard has a particular relevance in relation to the various discourses that have shaped the ethos of welfare (Dean and Melrose, 1999: $20 \mathrm{ff}$.). What was formerly considered to be a moral-political discourse by writers such as Titmuss, and other defenders of the Beveridgean welfare state, is now framed within the market discourses of liberal economics (c.f., Dahrendorf, 1995; Rose, 1996a, 1999; Titmuss, 1974). This new language of welfare (government from the social point of view) ${ }^{x l i x}$ is based primarily, Rose argues, on the politics of exclusion where welfare recipients are seen as abject 'despicable, lacking courage and self abasing'. He suggests that the 'characteristics of vile and degraded subjectivity are frequently ascribed to the subjects of the practices of security, charity, welfare and 
reformation'. They are 'cast into a zone of shame, disgrace or debasement, rendered beyond the limits of the liveable, denied the warrant of tolerability, accorded purely a negative value' (1999: 253; c.f., Pratt, 1997). Within social policy who is actually speaking, and why, must be weighed against the obverse - the discursive functions of silence and exclusion (c.f., Asen, 1996; Babich, 1992; Cook, 1993; Katznelson, 1986).

Who is actually speaking, from within a welfare and social policy perspective, can also be balanced against Foucault's radical prescription that 'all knowledge rests upon injustice' (1984c: 95). For example, he argued in Discipline and Punish that the forms of knowledge which welfare and bureaucratic professionals use to describe their tasks are circumscribed and inevitably reflect an implicitly judgmental system. Moreover, he contended 'the activity of judging has increased precisely to the extent that the normalizing power has spread' (1979a: 304). Consequently, 'knowledge' of welfare clients cannot but be mediated through the more powerful mechanisms of normalization and subjectification that his concept of 'limit-experience' helped to clarify. These new policies, he argued, 'required the involvement of definite relations of knowledge in relations of power, it called for a technique of overlapping subjection and objectification; it brought with it new processes of individualization' (1979a: 305). Spending time with the idea that knowledge and injustice are intertwined and letting it 'stick in the mind', as Hacking muses (1981: 32), does not mark out Foucault as an 'empty' nihilist. It is not tout lasse, tout casse, tout passe but a challenge that we ethically confront the contingency of our received 'truths'.

Examining the form of rationality that shapes current patterns of welfare policy and politics provides the clearest and most direct application of Foucault's ideas within social policy (c.f., Leonard, 1997). What matter who's speaking sets the ground for further reflections in social policy that reveals what particular 'limit-experiences' dominate current welfare policies. For as Foucault argued:

The judges of normality are present everywhere. We are in the society of the teacherjudge, the doctor-judge, the educator-judge, the 'social worker'-judge; it is on them that the universal reign of the normative is based; and each individual, wherever he may find himself, subjects to it his body, his gestures, his behaviour, his aptitudes, his achievements. The carceral network, in its compact or disseminated forms, with its systems of insertion, distribution, surveillance, observation, has been the greatest support, in modern society, of the normalizing power. (1979a: 304) 
However, the set of questions that arise in relation to the structural interweaving of individualism and totalitarianism within the nature of the state, while important, can only posit Foucault's significance (c.f., van Krieken, 1996). The enduring question of how to recognize, respond and attend to social need admits of no easy answer. There is much work still to be done to analyse what personal freedom might mean or, indeed, whether it is possible within the descriptive categories typically applied to the notion of freedom (c.f., Rose, 1999). In respect of welfare 'politics' Fraser's observation is incontrovertible that the politics of 'needs interpretation' jostles constantly with the 'factual' claims of need (1987).

This chapter, as well as the following, considers the nature and applicability of Foucault's thesis of governmentality and his relevance to social policy. The emphasis here is on the reflexive function of various 'discourses of truth' expressed within the justifications for and criticisms of welfare dependency and therefore how relevant Foucault's writing is to social policy analysis and theory. Welfare discourses about the perils of dependency rely on such binary opposites as 'good mothers and bad mothers, workers and shirkers, productive consumers and unproductive dependents, deserving and undeserving' Leonard, 1997: 20). These perniciously juxtaposed distinctions are integral to contemporary anti-welfare rhetoric. They have become mantras that embrace coded understandings of the 'limits' that shape contemporary discourses of 'appropriate' welfare policy.

Whether to focus on policies and schemes that universalize and generalize issues of social support within some ethos of social solidarity or to develop programmes and rationalizations that accord with an individualistic approach to need, risk, and provision is an ongoing debate within social policy. Because the welfare state developed in nation states that were 'both individualising and totalitarian', requiring contradictory processes of care and control, Foucault construed the welfare state as a 'problem' both of governance and structure. Thus the contested ground of the welfare debate is not a discrete aspect of modern governance. It is inseparable from the issues surrounding the rationalization of the state itself. Foucault's 'ethic of 'talking truth to power' was one that never really left him. His claim that all governing structures could be critiqued as examples of specific rationalizations represented his agonistic challenge to the politics 
and 'history of the present' (c.f., Connolly, 1987, 1993b; McNay, 1998; Owen, 1995; Thiele, 1990; Tully, 1999a, 1999b).

These questions can be examined using aspects of his theories about the nature and function of discourses - especially those relating to the normalization and formation of the subject. Foucault's important lecture On Governmentality is reviewed and some of his ideas expressed in that paper, relevant to social policy theory, are outlined. The secondary literature on governmentality and subsequent commentaries are also discussed, and particularly relevant to my emphasis is the realignment of governmentality studies within a critical theory perspective (c.f., O'Malley et al. 1997;

Stenson, 1998). Having discussed this debate the subsequent section (on governing poverty and ordering welfare) considers some aspects of the various discourses of welfare. Themes of autonomy, privacy, security and risk will be described before considering the implication of those linguistic paradoxes that shape social policy debates. Particularly important are how the 'silences of social policy' construe the ground of that debate and determine various discursive rhetorics of welfare in relation to individual rather than social perceptions of risk.

\section{On Governmentality: Foucault's 'Art of Government'}

This lecture, On Governmentality, has assumed legendary status within the Foucaultian canon (c.f., Barry et al. 1993; Burchell, 1993; Dean, 1999a; Garland, 1997; Hindess, 1997a; Miller and Rose, 1990; O'Malley, 1999; O'Malley et al. 1997; Stenson, 1998, 1999; Stenson and Watt, 1999). The lecture, delivered at the Collège de France in 1978, was first published in English in Ideology \& Consciousness in 1979 and then reprinted in Burchell et al. (1991). It has been the focus for a unique set of research activities that involve aspects of historical, political, sociological, criminological, anthropological and social policy scholarship.

Despite being yet one more neologism in our history of social and political ideas, Foucault's concept of governmentality strikes deeply at all those assumptions that locate the legitimacy of political power in some transcendent or precursive 'reality'. Applying his concept of governmentality within social policy raises the possibility that a different 'voice' (a new vitalism arising from the bio-politics of life itself) could be heard for those who have often been spoken for, and their lives so easily and pejoratively defined by 
others (c.f., Foucault, 1977b; Moussa and Scapp, 1996). It provides a new way to analyse how the ground of modern welfare discourse has been contingently shaped within the rationalizations highlighted by an analysis of 'limit-experiences'.

\section{(i) Defining Governmentality.}

Of the many available definitions of governmentality, Garland's is the most succinct (see also Gordon, 1991). He states that governmentality studies 'focused particularly upon the relations between two poles of governance: the forms of rule by which various authorities govern populations, and the technologies of the self through which individuals work on themselves to shape their own subjectivity' (1997: 174). It is the distinction between the implicit and the explicit aspect of how our 'conduct is conducted' that is important. How we willingly 'submit to government' is a central perspective of governmentality and is a key aspect of Foucault's thesis of 'limit-experience'. It provides a perspective on the manifold ways our contemporary Western world 'constructs individuals who are capable of choice and action, shapes them as active subjects, and seeks to align their choices with the objectives of governing authorities' (Garland, 1997: 175). This is true not only for the successful but also for those whose social and economic 'failures' require them to align their more limited 'welfare choices' in response to how they are governed as 'welfare clients' and assume the status implicit in that role. It is important to examine contemporary welfare practices as contingent discourses and not uncritically accept that they reflect common-sense 'truths'.

The development of Foucault's ideas about governmentality marked a shift in his thinking from tighter and obviously more encompassing notions of disciplinary power (themes of the overweening 'carceral archipelago') to questions of government in relation to the self (c.f., Connolly, 1987, 1993b). Questions and issues of how we are governed - the setting out of governmentality as a research area - was a different orientation, one 'that Foucault gradually substituted for what he began to see as the more ambiguous word, 'power" (Pasquino, 1993: 78). What he investigated was not systems of power but rather the 'cultivation of ... subjectivity in specific forms, [and how it is] aligned to specific governmental aims' (Garland, 1997: 175). He traced the core aspect of modern governance back to the transition of government from the autonomous power and actions of individual sovereigns to the complex political rationalizations that shape the modern nation state. O'Malley et al. have thus argued that 'governmentality 
studies are an analytics, not a philosophical theory, nor an empirical sociology of social relations' (1997: 509).

Foucault's thesis of governmentality was more a proposition that the intrinsic aim of government should no longer be defined as the maintenance of control and discipline 'the suppression of individual subjectivity'. He stressed that we are all 'active subjects' and that power is exercised through our willing participation in the processes of subjectification and thus the exercise of government rationality is not 'objectifying' but 'subjectifying' (c.f., Rose, 1999). Consequently, the study of governmentality is not a 'theory-based' discipline but is rather a 'problem-centred and present-oriented' focus. It challenges all those normative assumptions (see especially Habermas, 1992, 1994) that the patterns of administrative and political power are in any sense predetermined, either by reason of legal precedent, customary expectation, or pattern of communication (Owen, 1995: 503-504). Foucault's analysis of how modern 'arts of government' developed provides an insight into our present politics that prefers market-based individualism rather than the discredited models of welfare state obligation.

\section{(ii) Shaping Princely Advice and Conduct.}

Foucault began On Governmentality with an analysis of early treatises that codified 'advice to the Prince'. They involved representations about 'his proper conduct, the exercise of power, the means of securing the acceptance and respect of his subjects; advice on the love of God, obedience to God, [and] the application of divine law to the cities of men' (1979b: 5). They marked the first steps in the long process whereby the autocratic power of the sovereign was eventually transformed into the autonomous power of modern government rationality. Foucault suggested that the 'problem of government' first emerged in the $16^{\text {th }}$ century and that this derived from questions these treatises raised such as:

- How should we govern ourselves and what rituals are implied in that conduct of oneself in relation to government?

- What aspects of the religious government of souls and lives are involved in the pastoral expectations and oversight of the church?

- How should children be governed and who should decide? The emergence of pedagogy.

- How should the Prince govern the State? Namely, how should he govern himself and others in order to become the best possible governor? 
These new questions about governance were given impetus because of the growth of mercantilism, colonial expansion and the increasing sophistication of the administered state. A new category of administrative cadre was required that could relate the economic needs of developing nation states within an international framework of accords and protocols. They were also influenced by new demands for pastoral care and control, confronted by the Church during the Reformation and Counter-Reformation. It was the intersection of developing 'state' centralization, together with the problems of religious dissidence, which required an alteration in government practice. A growing administrative cadre was now increasingly dispersed and extended through the wider administrative demands resulting from colonial exploration. All of these factors contributed, Foucault thought, to an intensification of the problem of government. This involved questions about how to rule; who should specifically exercise this power and what should be the scope and range of the administrative methods required for these new tasks (1979b: 6).

These questions about practical government were first codified and explored by Machiavelli in The Prince. Foucault did not explore this text, as such - to consider 'what made up its scandalous or radically unacceptable aspects for its time' - but rather interpreted it as indicating 'an art of government'. As he continues, 'what mattered was to keep a safe distance from a certain concept of the art of government which, once shorn of its theological foundations and religious justifications, came down to the sole interest of the ruler as its object and principle of rationality' (1979b: 7, my italics). The enduring effect of his depiction of what governmentality initially entailed is reflected in contemporary political debates about welfare and social policy. Hindess argues, for example, that:

... there is no natural or essential basis for the subjection of the majority of the governed population to rule by a small minority. Their submission must therefore be seen as a precarious practical accomplishment. In this respect, to say that the government of the state has its own, autonomous rationality is to say that it has no source of legitimacy outside its own effectiveness. (1997a: 261)

The exercise of power itself was the source of real legitimacy. Thus the form of the rationalization of power rather than rhetorical justifications for it was more important. It is this 'unhinging' of supposedly immanent authority that is one of the more powerful implications of Foucault's governmentality thesis (Gordon, 1991: 9), as is the sense that the submission of the majority through the 'relations of power' is always a 'precarious 
practical achievement' (Gordon, 1991: 9). This reflects the ongoing preoccupation with 'limit-experience' that informed his intellectual journey and shaped his depiction of the bio-political regimes that control our lives.

The notion of instability is a constant refrain in the developing 'politics' of government. Foucault discussed in another paper (War in the Filigree of Peace, 1980b) that, contrary to popular assumption, there is no fundamental underlying institutional sense of peace within which war and violence can be resolved, or conducted as isolated instances of madness or stupidity. As he stated, 'beneath the visible brutality of bodies and passions, [there is no] ... fundamental rationality, permanent and linked in essence to what is good' (1980b: 17). Having argued that autocratic power is contingent and not ordained he is led to the assertion that what binds the Prince:

... to his principality is one of violence, of tradition or of treaties established with the
complicity or the alliance with other Princes; it remains in any case a purely synthetic
link and there is no fundamental, essential, natural and juridical connection between the
Prince and his principality. Corollary: given that this link is external, it is fragile and it will
be constantly threatened - from without by the Prince's enemies who seek to take over or
attack his principality, and from within by the subjects who have no a priori reason to
accept the Prince's rule. Finally, this principle and its corollary lead to a conclusion,
deduced as an imperative: that the object of the exercise of power is to reinforce,
strengthen and protect this principality which is not meant in its objective sense as the
entity constituted by the subject and his territory, but rather in terms of the Prince's
relation with what he owns, with the territory he has inherited or acquired, and with his
subjects. (1979b: 8, my italics) This insight of Foucault's that the 'arts of government' are not implicitly located with the control and disbursing of the tangible (the 'political' allocation of scarce resources) but rather reside in the relation the Prince has to the tangible and to the process of governing his subjects is significant. While protecting the tangible 'assets' of his principality is vital it is more important, as Foucault contends, that the Prince exercise the 'art of manipulating the relations of power'. This is an equally vital aspect of his defence of 'his realm'. The seeds of modern day government rationality are contained within the practices of these arts of government expressed as 'relations of power' and have some correspondence to his concept of 'limit-experience'.

If the core aspects of power do reside in 'relations of power', rather than in the disbursement of tangible goods, then it can be discursively challenged in a way that disbursing goods cannot. The latter can be granted under privilege or customary law and the largesse can be defended as the wilful, capricious or even legal acts of an 
autonomous sovereign. But 'relations of power', are open to different challenges that more subtly construe and constrain the autonomous powers of the Prince. They represent the first codification of a collective sense of agreement to consent to be governed by the Prince and that there are no a priori reasons for this.

Governmentality implies the 'willing consent' of the governed - the notion that our subjectification is internally derived through assent and not obedience. The implication of these ideas in respect of a fretful and, sometimes, hostile, welfare 'population' established the contemporary debate about welfare dependency (Leonard, 1997: 50). Thus the 'problem' of government is contained within the very 'arts' of government, the mechanisms by which autonomy came increasingly to be located in the practices rather than the personages of power. The irony of political power lies in its usage and application (c.f., Gordon, 1991) for, by governing, sovereigns were increasingly subject to the consequences of governance.

There is an oscillation, Foucault suggests, between the efforts of Princes to contextualize their powers in some separating and distinguishing juridical defence of their sovereignty, and the fact that the very manipulation of 'the relations of power' depends upon its opposite. Namely, respect for continuity and similarity rather than capricious acts of sovereign autonomy. Foucault's paradox, that the exercise of power requires the manipulation of the 'relations of power', points towards the precise dilemmas of modern politics. Namely, that so-called 'unbridled power', which constantly seeks legislative or other means to codify the 'sovereignty' of particular political objectives, nonetheless depends upon 'relations of power'.

Foucault's insight about 'relations of power' posits a reflexivity that is inherent in his thesis about governmental rationality. The dominance of one particular group is not simply won through rhetorical 'defeat' (claiming the 'sovereignty' of superior ideas) but involves the contingent control of the rationalization of government (c.f., Rose, 1999). Construing the fight' at the epistemological level of 'Grand Ideas' avoids all the complexity of contingent detail where, as Foucault contended, the real aspects of political power reside. It is the form of rationalization that is significant not the rhetorical content. As he argued: 
The art of government, as it appears in all this literature is essentially concerned with the question of how to introduce oeconomy, that is the correct way of managing individuals, goods and wealth within the family (which a good father is expected to do in relation to his wife, children and servants) and of making it thrive - how to introduce this meticulous attention of the father towards his family ... mutatis mutandis, and with all the discontinuities that we will observe, into the general running of the state. To govern a state will therefore mean to set up an oeconomy involving the entire state that is to exercise towards citizens, the wealth and behaviour of each and everyone, a form of surveillance, of control which is as watchful as that of the head of a family over his household and his goods. (1979b: 10)

These initial patterns of governance did apply models derived from protocols of family management but the 'general running of the state' required different methods that codified new domains of political practice. These changes in governance procedures reflected the formation, evolution and demands of national economies that brought new discourses about 'economic government' into play. The development of a 'political economy' ushered in new sets of complex relationships that were not subject to the previous stratagems and levers of sovereignty. The capriciousness and wilfulness of sovereign action was circumscribed by these new economic rationalities. As Foucault continues:

One governs things. But what does this mean? I don't think it is a question of opposing things to men, but rather of showing that government does not bear upon the territory but rather on the complex unit constituted by men and things. Consequently the things which the government is to be concerned about are men, but men in their relations, their links, their imbrication with those other things which are wealth, resources, means of subsistence, the territory with its specific qualities, climate, irrigation, fertility, etc; men in their relation to that other kind of things which are customs, habits, ways of doing and thinking, etc; lastly, men in their relation to that other kind of things again which are accidents and misfortunes such as famine, epidemics and death, etc. (1979b: 11)

Foucault shifts our focus from those traditional arguments that government essentially involved the defence of the realm - the territory of government - to the notion of a construction of a 'complex unit' of government; in other words, all these 'relations' that were not internally involved in protecting private property. His sense of what government entailed was much more complex and depended upon a wider range of factors not customarily thought to relate to government as such.

The new objectivity of political economy 'inaugurates a new mode of objectification of governed reality whose effect is to resituate governmental reason within a newly complicated, open and unstable politico-epistemic configuration' (Gordon, 1991: 16). An increasing requirement to govern the 'entire state' (the economy) thus shifts the focus of government from that previously inherent in governing a family to what Gordon 
defined as a 'liberal problem-space'. Notions of protection, support and responsibility, intrinsic to a family, are now recast within the wider issues and demands of state surveillance. National economies involving wealth, resources, social relations, and the territory of the state now becomes the focus of governance. The governing motif is no longer men in relation to their families but men in relation to the wider issues of the state.

Foucault argued that as national economies grew, new sciences of government emerged. It required a discursive change in description and explanation for the 'theme of economy' had to be inscribed 'on a different plane from that of the family' (1979b: 16). The family as a model for the exercise of the 'arts of government' has been supplanted. As he says:

$\ldots$ it was through the development of the science of government that the notion of economy came to be able to focus on a different plane of reality, which we characterise today as 'economic', and it is through this science also that it became possible to identify problems specific to the population; but we can also say that it was thanks to the perception of the specific problems of the population, related to the isolation of that area of reality that we call the economy, that the problems of government finally came to be thought, reflected and calculated outside of the juridical framework of sovereignty. (1979b: 16)

What he demonstrated is how government came to have 'a finality of its own' and was able to be 'distinguished from sovereignty'. But sovereignty, for Foucault, never has an implication of some a priori 'pure and simple right'. As he commented, 'no jurist, nor, a fortiori, theologian ever said that the legitimate sovereign is purely and simply entitled to exercise his power. The sovereign, to be a good sovereign, must always posit as his aim: "the common welfare and the salvation of all"' (1979b: 12). In relation to social policy and issues of welfare provision these ideas demonstrate how the dilemmas of protection, support and responsibility for whom, how much and when are woven into the actual practices of modern state governance. The explicit issue is 'how to be ruled, by whom, to what extent, [and] with what methods' (Foucault, 1979b: 6).

This dilemma cannot be resolved by epistemological investigations into the validity of separate political meanings and attempting to resolve their constant antagonisms. What it requires is patient unravelling of how we actually do govern ourselves and create patterns of welfare services; to reveal how the complexity of the rationality of government depends on 'relations of power'. These are always reflexive, systematic, changeable yet dependent on some interactive relations of commonality. For Foucault, 
the 'common welfare and the salvation of all [an articulation of common good] means essentially obedience to the law, either that of their earthly sovereign or of God the absolute sovereign'. He continues, 'in any case, what characterizes the end of sovereignty, this common and general good, is in sum nothing other than submission to this sovereignty' (1979b: 12). But he now discerned an important shift:

\begin{abstract}
I believe we can see emerging a new kind of finality. Government is defined as a right manner of disposing things so as to lead, not to the form of the common good, as the jurist's texts would have said, but to an end which is 'convenient' for each of the things that are to be governed. Which implies a plurality of specific aims; for instance government will have to ensure that the greatest possible quantity of wealth is produced, that the people are provided with sufficient means of subsistence, that the population is enabled to multiply, etc. (1979b: 13)
\end{abstract}

All of the above tasks are now aspects of the disposition of government. That is to say that the 'art of government' resides not simply in sole obedience to the laws that sovereign power proposes (for 'law and sovereign were absolutely one and the same thing'). The emergence of a 'plurality of specific aims' pushes the issues of governance towards solving the more intangible issues of general economic well-being and biopolitics.

The development of state power no longer rested on the ability to rule by means of legal injunction and enforcement. Government increasingly involved consideration of the more general and hard to predict issues of economic shifts and developments. Governance therefore, Foucault suggested, now involved steering the ship of state tactically. The questions sovereigns now faced were 'not a matter of imposing laws on men, but rather of disposing things, that is to say to employ tactics rather than laws and, if need be, to use the laws themselves as tactics' (1979b: 13, my italics). He is certain that this marked a major 'turning-point' in the evolution of government during the $16^{\text {th }}$ and $17^{\text {th }}$ centuries, particularly as mercantilism grew, consequent upon colonial exploration and acquisition. As he argues:

$\ldots$ whereas the end of sovereignty is internal to itself and possesses its own intrinsic instruments in the shape of its laws, the finality of government resides in the things it manages and in the pursuit of the perfection and intensification of the processes which it directs, and the instruments of government instead of being laws, now come to be a range of multiform tactics. Within this form of government, law is not what is important. (1979b: 13)

What is more salient, he suggested, are diligence and wisdom that he interprets, not in terms of fidelity to 'divine and human laws, of justice and equality, but rather in knowledge of things, of the objectives that can and should be attained, and the 
disposition of things that are required to reach them'. This is the new 'wisdom' that can be expected of the sovereign. It leads on to Foucault's notion of diligence in the 'art of governing'; implying that 'who governs [is] capable of governing only to the extent that he thinks and acts as if he were in the service of those who are governed' (1979b: 14). The shift from a capricious exercise of Princely power to the exercise now of the 'arts of government', in service of the 'common good', is complete.

The new imperative of the 'reason of state' implied that we were governed by principles that are knowable and rational not by reference to 'natural or divine laws', or through the principles of wisdom and prudence, however judiciously applied (c.f., Foucault, 1980b). Consequently, these initial assumptions about 'the reason of state' were not capricious or indiscriminate but reflected the belief that there was an intrinsic rationality in the structures of political power. The state had not yet taken on the pejorative cast it now has where it was seen to infringe 'on the principles of law, of equality and humanity in the sole interests of the State'. As he suggests, 'the art of government instead of seeking its foundation in transcendental rules, cosmological models or philosophicalmoral ideals, must find its principles of rationality in that which constitutes the specific reality of the State' (1979b: 14, my italics).

The arts of how we are governed are not immutable and because they reside in an internal logic of rationality can be examined and re-examined. Hence Foucault's agonistic assumption - that which is made can be unmade, and if we see the state as 'our instrument' then we can change it. As he wrote elsewhere, what 'is found at the historical beginning of things is not the inviolable identity of their origin; it is the dissension of other things. It is disparity' (1984c: 79).

(iii) Social Statistics: Counting, Ordering and Controlling 'Populations'.

Undoubtedly lan Hacking's thesis, in Making Up People (1986c) about the function of registering and counting populations, owes something to Foucault's insights. He argues that statistical enumeration inevitably promoted levels of categorization. Consequently, 'defining new classes of people for the purposes of statistics' shapes 'the ways in which we conceive of others and think of our own possibilities and potentialities' (1990: 6). Foucault's governmentality thesis established that there was a relationship between how specific populations were to be governed and how economic resources could be most 
efficiently used. Forming the individual as an object of knowledge, governing through individuals and their complex patterns of individual allegiances (their solidarities, defined more broadly than the family), became the norm for these new aspects of political control.

These statistical perspectives about certain populations, as Foucault argues, 'render possible the final elimination of the model of the family and the re-centering of this notion of economy on something else'. The family 'disappears as the model of government, except for a certain number of residual themes of a religious or moral nature. What, on the other hand, does emerge is the family considered as an element internal to population, and as a fundamental instrument of its government' (1979b: 17; c.f., Donzelot, 1979).

The emergence of the idea of a population is significant in that it:

... comes to appear above all else as the ultimate end of government, that is the welfare of the population since this end consists not in the act of governing as such but in the improvement of the condition of the population, the increase of its wealth, longevity, health, etc; and the means that the government will use to attain these ends are all in some sense immanent to the population. (Foucault, 1979b: 17)

The transition from an 'art of government to a 'political science', from a regime dominated by structures of sovereignty to one ruled by techniques of government, Foucault suggests, occurs in the $18^{\text {th }}$ century. What facilitated the emergence of these techniques was a shift to new themes about a defined 'population'; the requirement to assess and measure these 'populations' that 'consequently centres on the birth of political economy' (1979b: 18).

Development of rudimentary statistics both ordered and divided that which was to be governed. As Foucault argued:

... the substitution for a society of sovereignty of a disciplinary society by a governmental one; in reality we have a triangle: sovereignty-discipline-government, which has as its primary target the population and as its essential mechanism apparatuses of security. In any case, I wanted to demonstrate the deep historical link between the movement that overturns the constants of sovereignty in consequence of the problem of the choice of government; the movement that brings about the emergence of a population as a datum, as a field of intervention, and as an objective of governmental techniques; and that which focuses on the economy as a specific sector of reality, and on the political economy as the science and technique of intervention of the government on that field of reality. (1979: 19) 
While he clearly postulates the notion of a triangle, involving some aspects of an interlocking system, there is an inertial residuum in our political thinking about the historicity of the movement from sovereignty to disciplinary society to governmental. The last in the sequence carries more perceptual 'weight' and thus appears to be superior to the predecessors.

Examining the hegemony of neo-liberal common sense, and the internal logic of its criticism of welfare - its multitude of 'dependencies' and 'risks' - requires an analysis of the dynamism of this 'historical inertia'. Posing the 'system' of the interlocked triangle is useful but perhaps not totally satisfying. We need not be naïve in understanding what challenging that 'hegemony' entails. As Ewald has argued, what 'makes society, as it were, disciplinary is precisely the fact that disciplines do not create partitions. On the contrary, their diffusion, far from dividing or compartmentalising, homogenises social space' (1992: 170, my italics). In addition, the differences between left and right are 'collapsed' by a focus on the rationality of government, based upon market-place realities and the managing of politics. Doxiadis suggested that Donzelot (in The Policing of Families, 1979) had shown:

... that social democracy and the whole reformist politics of the welfare state was by no means in radical opposition to right-wing and liberal parties, by demonstrating through careful argumentation that, in terms of strategy, it actually belonged together with them within the political-institutional complex which supports and perpetuates present-day Western society. (1997: 519)

Because the state has been 'socialised', as Donzelot argued, the classic argument that the state was simply an expression of ruling class power was no longer acceptable. The 'levers and/or targets of resistance and opposition' were not the state, nor existing political parties but the 'field of the social ... the field of micro-social relations and regulatory interventions in everyday practices ... [was] the field par excellence where modern power was exercised (Doxiadis, 1997: 520).

\section{Governmentality: Promise and Debate}

The redrafting of the 'welfare state' into a 'welfare society' marks not only a major shift in how welfare services are explained but it also reworks justifications for actual social provision (c.f., Powell and Hewitt, 1998). These arguments seek to eliminate the 'passive' welfare state and establish 'active' welfare societies. The phrase 'from a welfare state to a welfare society' encapsulated the intention of neo-liberal social 
theorists to create a minimalist welfare society. This discursive shift in welfare policy was a particular example of neo-liberal valorization that 'exploited ... 'monetarist' arguments concerning the inflationary political cycle of the welfare state and the ungovernability of liberal democracies' (Dean, 1997: 213). It removed the state from direct responsibility for the provision of welfare services and initiated purchase of service contract procedures. Social services were to be delivered by separate providers who contested with each other for limited funding available through contract.

Welfare themes and policies have constantly been reworked within different neo-liberal valorizations of risk discourses. They reinforced the state as responsible for the provision of targeted services, a 'minimal safety net' but not universal prescription (c.f., Beck, 1992). Foucault saw 'security' as the 'dominant component of modern governmental rationality' such that his initial notion of a disciplinary society is better expressed as a 'society of security' (Gordon, 1991: 20). The 'language of risk' in relation to welfare had fundamentally changed. Where 'security' as a theme of modern life had been allied with the social (namely, former State welfare institutions of Social Security) risk, particularly in relation to welfare and social policy, was now expressly an issue of individual responsibility and management (c.f., Culpitt, 1999; Rose, 1999). The linguistic and rhetorical reworking of security away from any sustainable reference to the social and its firm assignment to individual risk management is a stunning shift in political ideas.

The individual valorization of risk and the fracturing of the domain of the 'social' into divergent sites of contest have all contributed to the observation that we can typify our present as 'reflexive government'. That is to say that the most powerful levers of change are the multitudinous ways through which we are governed. The introduction, for example, of contestable internal markets into the previously powerful welfare bureaucracies of health, education and welfare (including the criminal justice system) have dramatically recast the functioning of those previously normative welfare state institutions. They are reflexively required to account for themselves in ways that accurately mirror the patterns and practices of how citizens of government are now reshaped into consumers of governmental practices. Foucault's notion that we are governed by means of the processes by which we assert and claim our freedom from 
government is quintessentially part of his deliberate aim to alter 'taken-for-granted' perceptions (c.f., Doxiadis, 1997).

The 'central critical claim' of the governmentality literature - 'audacious and devastating in its political implications' - is that we are ruled 'through our freedom'. What we 'cherish as our autonomy, our individuality, our independence of power relations, is precisely the basis for our being governed by others' (Garland, 1997: 196). However, not all neoliberal reforms of the public sector health and welfare services can be seen as examples of 'governing through freedom'. There are procedural constraints that are imposed and, as Foucault says, we 'are obliged to be choosers but ... are not therefore made to be free'. Whatever he meant by this he doesn't mean it to apply in some conceptual vacuum. Practices and arts are just that and no more! They operate in the 'real world' and not in the mind. I do agree with Garland that an exuberant, uncritical overuse of these ideas does allow neo-liberal advocates to 'repeat their propaganda'. Mantras of common sense, which surround neo-liberal rhetoric, are very clever marketing ploys against the presumed 'florid' and 'fanciful' excesses of social democratic theorizing.

\section{(i). Agency, Management and Bureaucratic 'Practice'.}

Garland expressed some cautions about the usefulness of this notion of being 'governed through our freedom'. For example, he argued that applying governmentality 'literature' to an analysis of theory making in criminology (and equally within social policy) it is possible to conflate freedom ('the capacity to choose one's actions without external constraint') with agency (the 'possession of the power to act'). Requiring agents to take managerial responsibility for the outcome of decisions that were formerly a 'shared risk' of the total welfare or health bureaucracy can produce adverse effects. At the very least it is an interesting comment on how preoccupation with managerial risk (within organizations) construes responsibility for the dispersal of risk in major welfare institutions.

Such governance 'practices' are seen in the processes of restructuring where these agencies and institutions have been subject to perpetual cycles of administrative review. The managerial issues involve the typical neo-liberal restructuring practices of devolving 'budgetary allocation powers while cutting budgets ... [which] often means that subordinates in organizations have to take on the unwelcome task of imposing cuts' 
(1997: 197-198). This small instance of Foucaultian 'genealogy', involving current managerial practice within an environment of constant risk, is writ large all over the deregulating public policy sectors of much of the Western world - with the possible exception of Nordic states. It is an interesting example of the globalization of a governing 'practice' that has assumed wide significance. ' These aspects of practical management demonstrate how managing individual 'risk' is used as a dogma for, and a rationalization of, institutional change. If freedom and agency are conflated, then deconstructing the rhetoric around agency and its effects is crucial to an analysis of welfare and risk.

Elucidating how government is done, and not just what it does, provides a new way to consider welfare policy. Certainly, as Garland suggests, we need to understand the pragmatics of programme-implementation and the processes through which rationalities come to be realized (or not) as actual practices' (1997: 200). It is facile to argue that individual risk is not part of the common-sense reality that we all must deal with. The point, rather, is to establish that the genesis of risk arises from the social structure part of the actual pattern of governance, and not as integrally part of some individual consciousness, superordinate to social process. Analyzing the conduct of government provides a way to move beyond the recursive debates about individual rights and autonomy. One of Foucault's concerns was to:

... challenge the idea of a sovereign subject which arrives from elsewhere to enliven the inertia of linguistic codes, and sets down in discourse the indelible trace of its freedom; to challenge the idea of a subjectivity which constitutes meanings and then transcribes them into discourse. Against these ideas I would advocate a procedure which maps the roles and operations exhausted by 'different' discoursing subjects. (1991a: 61-62)

The assumption, which dominates contemporary debate about self-responsibility and the perils of welfare dependency, that risk is an integral part of that individual consciousness arises from this fetish to articulate 'the indelible trace of its freedom'. In his analysis of the processes of subjectification within modernity (his concept of 'limit-experience') Foucault argued that the idea of a sovereign independent subject was flawed. We do not 'arrive from elsewhere', nor are our meanings constituted out of some pre-existing ontological subjectivity. If his analysis holds, then the welfare rhetoric that criticizes need and dependency as a failure of individual responsibility to manage and defend against risk can be challenged. 
He was always concerned to argue that power as consent, representative only of a mutual contract, could not be seen to justify the normative 'rules' of state intervention (Hindess, 1996b: 138). How we are governed is not simply the application of some form of contractual rights; governmentality, for Foucault, is more diffuse and complex. He describes the capillary nature of power as an exemplar of conduct and not an articulation of rights. Consequently, the nature of contemporary politics is about power as process and cannot simply be explained as the operation of contractual rights. $\mathrm{He}$ argued that 'the founding contract, the mutual pledge of ruler and subjects, [is] to function as a sort of theoretical matrix for deriving the general principles of an art of government' (1991c: 98). The 'art of government' implies patterns not rules, processes not policies. How those patterns and processes have refashioned our thinking about risk and the rationalizations of welfare policy warrants more investigation. The detailed work of this Foucaultian critique is only now being undertaken (c.f., Procacci, 1989, 1994; Stenson, 1998, 1999).

(ii). Applying a Foucaultian Critique: 'The Hazardous Play of Dominations' (Foucault, 1984c: 83).

O'Malley et al. provided the first significant reappraisal of the governmentality literature. They argue that the 'earlier tension between pessimism of intellect and optimism of will that yielded an extraordinary lyricism in genealogical prose' has not been sustained. The apparent idiosyncrasy of Foucault's work and the inability of sociologists, historians or philosophers to 'lay claim' to him has contributed to this relative weakening of the initial 'tension' that O'Malley et al. describe. What they predict is 'either the twilight of critical genealogies or the growth of political heterogeneity and potential conflict with the history of the present' (1997: 508). They contend that the initial:

... mark of the genealogist had been a refusal of an ideological critique oriented to the discovery of hidden logics, interests or meanings, for example, human rights as the smokescreen of the bourgeoisie. Ideological critique gives itself the task of 'unmasking' 'disguised' ideological interests. Genealogical work, which has had governmentality studies as its leading edge over the last decade, has consistently characterized criticism as assuming a negative theory of power: power as prohibitory rather than inciting. The texts of criticism, it is argued, neglect the possibility of government operating through the formation of subjects, a positive form of power. (1997: 506)

This 'denial of criticism' has implications for those social policy analyses that do seek to ground social concerns in some valid form of critique. If we do define the proper focus of Foucault's genealogical studies as residing 'over and against criticism/critique, the result [as O'Malley et al. argue] is a history of the present that downplays interpretations of 
history as systematically antagonistic and violent' (1997: 506). They base their argument on the observation that Foucault did hold that 'the writing of history was the struggle for interpretive dominance'. His 'history of the present', they contend, could only be fully understood if we respected his notion of 'rupture and emergence after the clash of forces'.

This is certainly an assumption that any consideration of Foucault's ideas about the necessity to transgress the rationalizations of 'limit-experiences' would endorse. They point towards Foucault's statement that 'humanity installs each of its violences in a system of rules and thus proceeds from domination to domination' (1984c: 85). They query the initial stance in governmentality studies that focused too narrowly on mentalities of rule and which avoided his agonistic speculations. For example:

In order to suggest a provisional assessment of what neo-liberalism 'costs to existence', an assessment of its effects would be necessary. However, studies of government have constructed their theoretical object as one of political rationality and technologies, a restriction that precludes problematizing effects, and thus presumably eliminates the possibility of assigning the costs to existence of any form of governmentality, including neo-liberalism. (O'Malley et al., 1997: 509)

If social policy can apply governmentality studies to examine the 'forms of rationalization' that constitute any particular set of policies then the direction of this work will more clearly be associated with how his ideas can be used as genealogical critique. We cannot pin everything on analyses of the 'metaphor of discourse' for 'discourse [alone] does not do the work'. We do require analyses that describe the world in 'all its peculiar and idiosyncratic detail' (Hacking, 1998b: 86). What social policy theory needs to develop is a 'critical governmentality theory' that encompasses 'the work of realist social sciences, who wish to study how social relations really work' (Stenson, 1998: 334). We do need an analysis of the practicalities of explicit welfare policies and not just analyses of discursive rhetoric. As O'Malley et al. argue, there is 'abundant evidence that contestations, resistances and social antagonisms shape rule through systematic provision of alternatives' (1987: 510 ).

\section{(iii). Welfare 'Crises': Domination and Power or Disorder and Threat?}

Pasquino has suggested an interesting counterpoint to Foucault's arguments about the 'hazardous play of dominations'. Foucault, as we saw earlier, was preoccupied with trying to solve (or perhaps more accurately explicate) the intransigence of the dilemma of the 'one and the many'. His analysis was premised on turning the classical debate 
about domination and power on its head and concentrated on 'the fabrication of subjects rather than the genesis of sovereignty' (Pasquino, 1993: 79). He suggests that Foucault is misguided and that the real issues about the 'tricky adjustment' of the welfare state 'problem' do not arise from domination and power but rather express concerns about disorder and threat. He concluded that:

... the starting point of any political theory is the problem of disorder and threat and the need to overcome both of them. Thus it would be necessary to set against the classical theory of forms of government a typology of the forms of conceptualizing threat, a conceptualization that determines the variation of the theories of political order. It seems to me that that this question of disorder and threat must replace the issue of domination and power and that it alone is capable of accounting for the problematic of the government of others. For without the threat of disorder, there simply would be no reason for imagining power or government - if not in the terms that Foucault himself ended up completely rejecting: I mean repression (or domination, which here amounts to the same thing). (1993: 82)

In order to make his 'case' Pasquino refers to Foucault's conclusions drawn from his examination of Hobbes' Leviathan. Foucault argued that what this is really about is not the 'conflict of weak versus strong or, in any case, of one group versus another; thus it does not arise from a difference in nature but quite the contrary, from equality, from a lack of difference or insufficient difference'. This is not an analysis that hinges on the pre-eminence of dominations and power. The real issue for Foucault here is that 'the weak one is never weak enough to accept subordination, nor the strong one ever sure enough of supremacy to feel spared the threat of the other' (1993: 80). The linkage to our modern welfare and social policy debates is clear where there is this uneasy and constant irritation between the acknowledgement of needs and what to do about them.

How we conceptualize welfare as a 'problem' and propose alternate solutions are better analyzed as issues of disorder and threat rather than domination and power. The 'welfare problem' may well arise out of a perception of discord rather than the usually juxtaposed concerns that the wealthy dominate and control the poor. The depiction of the welfare state as a quasi-Foucaultian disciplinary activity was never a satisfactory explanation for the complexity involved (c.f., Hewitt, 1983; Osborne, 1998b; Rose, 1999). While aspects of the carceral society still echo in relation to depictions of welfare policy and practice it is too simple to associate all the issues involved in analyzing state welfare systems with various control themes. It certainly did not reflect Foucault's own ideas about welfare policy and social security (c.f., 1981b: 235, 1988a). The typical 'welfare state problem' could not be described solely as an issue of modern governance. 
On the contrary, he thought that it must be understood as 'one of the extremely numerous appearances of the tricky adjustment between political power wielded over legal subjects and pastoral power wielded over live individuals' (1981b: 235).

\section{(iv). Expert 'knowledges' and Dominant Risk Discourses.}

Placing the concept of risk alongside Foucault's theory of 'knowledge/power' reveals another important focus. If epistemological examination of welfare ideologies as 'expert' knowledges is no longer possible, we can perhaps advance the debate by relating how these 'knowledges' about welfare are structured and patterned to Beck's discussion of reflexive modernization (1992). Focusing only on contending at an epistemological level about 'meanings' has been unsuccessful in confronting neo-liberalism. Previously, seeking the irreducible and defendable core of social policy's concerns has led us away from the paradoxical. The empirical and positivist tradition had no time for such speculation (c.f., Goodin, 1985, 1988; Titmuss, 1970, 1974). So much of the effort was to establish the actual legitimacy of need and to argue that legitimacy rationally. The brutalities of disadvantage needed no philosophical 'hair splitting'!

The rhetoric of risk and chance is always 'reduced' to practical threats and specific solutions proffered. It will be important to understand how, while:

... breaching the normal form has to be registered as chance because it is not anticipated', all explanations of these events seek to return to a basis of rationality. Events may be seen as arbitrary but that explanations 'must be shown to have an order of ... [their] own, a secondary normality as it were. (Luhmann, 1993: VII)

Social policy must ground its rhetoric not only in efforts to reshape epistemological arguments supporting welfare and the urgent practicalities of social disadvantage, but also consider the way that social knowledge is constructed. If the arguments for a reconsideration of the rationalizations that dictate specific welfare policies are couched only in rhetorical terms they will be easily dismissed. Normative injunctions, moral pleas, diatribes and other efforts to elicit general support for welfare policies have been difficult to sustain. We have been looking in the wrong place! As Dean contends:

... what we call welfare or social policy, cannot properly be understood within a history of ideologies, within the evolution of morality, or even within an economic history. It must be understood, above all, in terms of governance and the 'forms of life' which are promoted by it ... [we require] a history of poverty, then, not as one of guilt, conscience, public opinion, and social reform, but as one of the mechanisms of rule, the forms and uses of knowledge, and the ethics of the conduct of life. The problems of poverty, in many ways paradigmatic of those of welfare and social policy, must be understood in relation to 
issues of morality and economy, to be sure, but their constituent domain is one of governance. (1992: 218, my italics)

Foucault's analysis of the 'practices' of how power/knowledge constructs patterns of political discourse provides fresh analytical tools for social policy to confront the hegemony of neo-liberal welfare policy. It will be useful to examine the facets of the respective welfare rhetorics to see what they affirm as well as that which they deny. Deconstructing and revealing the false imperatives of such reasoning that denies the relevance of these governance factors must remain the core task for critical social policy theory. As Doxiadis argued, it was an 'ironic consequence' that 'the very task of liberation itself has always led to an acceptance of sovereignty, on both the collective and individual level' which Foucault saw as 'perhaps the most insidious trap of the modern ideology of power' (1997: 534).

While his analytics of practice is important we still require the further patient unravelling of the meanings as well as the functions of contested welfare explanations (c.f., Walters, 1997). That will necessitate some understanding of how irony and the paradoxical, while explicitly denied as having any bearing on social science research, nonetheless construes the grounds of much social science debate and shapes the new 'subjectivity' of anti-welfare discourse (c.f., Maxwell, 1998; O'Hara, 1991b, 1992; Rose, 1999).

\section{Welfare Discourses: Aspects of Foucaultian 'Limit-Experiences'.}

The question ('what matter who's speaking') importantly established the primacy of function and practice of discourse - rather than the personal purposes of the author. This approach to the functioning of discursive practices permitted Foucault to ask a wider series of questions such as:

- What are the modes of existence of this discourse?

- Where does it come from; how is it circulated; who controls it?

- What placements are determined for possible subjects?

- Who can fulfill these diverse functions of the subject? (1977a: 138)

While these questions have often been applied to textual analysis within other disciplines they are similarly important within social policy in relation to the social discourses of welfare, dependency, security and risk. All of the above four questions can be addressed to the issues of subjectification and control exemplified in welfare discourses and practices. The welfare state developed around sets of binary distinctions that arose out of specific discursive practices. For example: 
... poverty distinguished from pauperism, health from ill-health, good mothers from bad mothers, law abiding from delinquent. The subjects of the welfare state still find themselves located within these discursive constructs, their subject positions carrying with them a moral judgement and an incitement, in the present or in the future, to moral injunction by state apparatuses. But perhaps most important for the constructing of subjectivity within the area of state welfare has been the discursive division between the subject as dependent or independent. (Leonard, 1997: 50)

To question what we mean by welfare practice, and the discourses that define them, requires an examination of how and why they were framed 'as a system of possibility for knowledge' (Philp, 1985: 69). Both the defence and critique of welfare policy bespeaks 'practices' as well as the reasoned 'silences' (the ability to foreclose debate) of selective expert opinion. If the discourses of welfare do exemplify aspects of governmental rationality then how are we to speak of welfare without creating a 'body of knowledge for the elite' interpreters and commentators (Veyne, 1997)? Finding an answer to that question requires an analysis of the background as well as the foreground for how such elite concepts of welfare are created.

Foucault's depiction of discourses as genealogical practices, indicative of particular 'limit-experiences', provides one possible approach to such analysis. He undermined 'the power exercised on our minds (strictly speaking, in and through our thinking) by an idea, discourse, practice, institution, etc., by exposing its strategic function, its contribution in our subjugation' (Berard, 1999: 222; c.f., Bové, 1980; Shiner, 1982; Schneck, 1997). His critique was grounded in an assessment of the discursive constraints of the present together with his desire to expose these 'limit-experiences'. It is the ironic/paradoxical linking of the practices of subjectification, with there being no escape from the necessity to understand the rationalities of ideology, that poses most problems to us and which has him labelled as anti-humanist and nihilistic.

The combination of these factors can also account for the vaguely apocalyptic tone taken in many of his works' (Roth, 1991: 427). As I have argued, the rigidity of such an interpretive stance is not justifiable, and social policy theory can find in Foucault's thesis of governmentality a way to recast rigid patterns of welfare analysis. The real issue, for social policy theory, is not to try to resolve the paradoxical features of such Foucaultian analyses but to see them as representative of the practical tasks we must accomplish in order to be able to 'think differently' about things we presumed immutable. That his 
ideas are sometimes expressly ironic or paradoxical does not imply an essentially nihilistic stance, nor is it one that social theorists need reject.

The problem for all literary or social critique, reliant on normative reasoning, is that it fails to consider Foucault's contention that 'no form of discourse, including the critique of society, is exempted from a dependence on power as the condition of its possibility' (Touey, 1998: 94). For, as Hacking has contended, 'if we want to engage in certain pursuits (call them the natural sciences or even the pursuit of truth in our tradition), we must reason with our reasons' (1982c: 66). It requires a genealogical approach (1984c: 76 , c.f., Procacci, 1989, 1991, 1994) that expresses the 'gray, meticulous, and patiently documentary' record of welfare data and all the aspects of governmental rationality that surround it. Foucault's approach to critical reflection (one that 'reasons with our reasons') was that:

... criticism is no longer going to be practised in the search for formal structures with universal value, but rather as a historical investigation into the events that have led us to constitute ourselves and to recognize ourselves as subjects of what we are doing, thinking, saying ... It is not seeking to make possible a metaphysics that has finally become a science; it is seeking to give new impetus, as far and wide as possible, to the undefined work of freedom. (1984a: 45-46)

\section{Welfare 'story lines': Freedom, Limits and Subjectification.}

Asking questions about who is speaking and what are they speaking, as we reflect on the current discourses that establish the arguments in support of a minimalist welfare society, focuses on the function rather than the stated intent of this rhetoric (c.f., Shipley, 1991). Articulating the denied or hidden 'voices' of the subjugated has not had much impact on current welfare policy that subjectifies need and dependency as abject moral failures (c.f., Rose, 1999). Nonetheless, it is important to understand how such welfare discourses developed, and to demonstrate how the nature of them depends upon a particular application of risk discourse.

It may be that discourse analysis will not yield much in the way of new political tools. By itself it will not alter current policy programmes, but efforts to uncover the personal and idiosyncratic details of the multitude of such lives are important if we are to fully understand the 'history of the present'. As Hacking argues, it is 'not just discourse, not just power, not just suffering' (1998b: 86) but to the intersection of all of these that we must turn if we are to re-examine the rationalizations that constitute our welfare normalizations as specific examples of 'limit-experience'. Rose captures this well: 
To analyse, then, is not to seek for a hidden unity behind this complex diversity. Quite the reverse. It is to reveal the historicity and the contingency of the truths that have come to define the limits of our contemporary ways of understanding ourselves. By so doing, it is to disturb and destabilize these regimes, to identify some of the weak points and lines of fracture in our present where thought might insert itself to make a difference. (1999: 276-277)

'Story Lines': Patterns and Themes of Welfare Discourses. Hajer developed a schema to describe the function of discourse within ecological modernization and how these new social orders were expressed as 'story lines' that captures another aspect of Foucault's depiction of 'limit-experience'. These 'story lines', as he contends, involved three ecological discursive themes - 'reductions, exclusions and choices' - that separate out new social orders within ecology. All three contain elements that must be worked through before any 'interweaving of correlations' and a new ecological 'story line' can be established (1996: 257). The interweaving of these three themes provides a possible model with which to critique the dominant discourse in contemporary welfare policy that has fashioned the 'story line' of a minimalist welfare society. Neo-liberal welfare 'story lines' construct a discourse about the perils of dependency and the necessity to make distinctions between the deserving and the undeserving; to limit, control and exclude. For example, Shipley argues that past benefit levels 'had a negative effect ... the generosity of the benefit system had become a poverty trap' (1991: 12). Charting the range of assumptions that are part of the debate about a minimalist welfare society highlights welfare dependency as a specific sub-set of pejorative welfare 'story lines'.

Applying these ideas to the task of clarifying our understanding of welfare dependency we can depict dependency as an issue of reduction, as an aspect of social exclusion or as indicative of the specifics of choice as well as the epistemology involved in the process of such choosing. These three aspects of dependency (reduction, exclusion and choice) correspond in significant ways to the 'registers of meaning' first formulated by Fraser and Gordon when they proposed their model of dependency (Dean, 1991a: 60 ff.). They describe four aspects:

- Dependency expressed as an economic register, where the requirements for survival depend on the action of another.

- Dependency depicted as a 'socio-legal status', where personal identity is construed on the basis of status.

- Dependency resulting from political subjection.

- Dependency defined as a moral/psychological question depicting personal inadequacy and consequent neediness (1994a: 312). 


\section{(i). Dependency: Risk and Reduction.}

The issues surrounding dependency are often framed as risk reduction - borrowing from the jargon of the business world the need to limit exposure to risk. The stigma of dependency is a reflexive counterpoint to success. Here legitimate needs and social dependence are defined as 'sectorial interest', not rights, or legitimate areas for universal or widespread recognition. The counter-argument to these economistic views is the basic concern of social policy, namely that:

... dependency and social needs are not merely caused by social forces and do not exist as pure facts. They are constructed within the discourse of social policy as categories, classification systems and forms of knowledge by individuals and groups within the political, administrative and economic spheres. (Hewitt, 1983: 67-68)

(ii). Dependency: Aspects of Social Exclusion.

The typical language of welfare is explicitly normative. The subjectification of welfare dependency defines dependency as inhering in the self of the welfare beneficiary or claimant rather than any social or needful situation that might be assumed to have created it. While 'client', or increasingly 'customer', expresses a particular set of ideas the older terms of 'beneficiary' or 'claimant' established a different discursive ground. The ethos of the former welfare state however reluctantly, given various systems of means testing and regulation, supported the notion that it was an acceptable status to benefit from or to claim income maintenance or other social and health services. The ethos of the new welfare society alters how the status of those in need is legitimated and 'moral economy, paternalism and the right to subsistence, are displaced by political economy, the contract, and the laws of market society' (Dean, 1992: 220).

For much of the twentieth century the ethos of the welfare state was based on entitlements to welfare, health and educational opportunities and access to services mandated through the legitimacy of citizenship rights. The various metaphors of obligation that informed this ethos were still reliant on the normative conjunction of church and state to set out welfare policy that reflected the aims of the social gospel (c.f., Culpitt, 1992). Despite complex means testing procedures a great deal of discretion was still left in the hands of individual caseworkers who were the pivotal point for access to services. Once past the deserving/undeserving 'gaze' of the social worker the fact of need or dependency was recognized and legitimate status accorded the claimant or beneficiary. A welfare compact was struck that beneficiaries were morally 
obliged to get off the welfare rolls as soon as they were practically able. Despite pejorative overtones, dependency was, nonetheless, legitimated under certain criteria.

However, within the new discourse of a welfare society dependency is related not only to poverty, youth, ill health, per se, but to the 'problem' of having 'poverty, 'youth' and 'ill health' as an expression of the willed self. Any explicitly general contexts of disadvantage are denied. Such systems of exclusion are represented in the language that is used to describe the status of being on welfare. A pattern of political mentalities and governmental practices emerged that sharpens the divisions between the autonomous and the dependent, the contented and the discontented, the haves and the have-nots' (Rose, 1999: 254. The social 'facts' of need and dependency are now explicitly reified into moral categories of success or failure "within the laws of market society'. This represents a recasting of moral responsibility from the state to the individual.

The homeless, as Rose suggests, are now described in newly camouflaging language as 'rough sleepers' and the unemployed as 'job seekers'. We cannot simply talk of 'dependency as a social relation of subordination' (c.f., Fraser and Gordon, 1994a). Subordination now resides in the self of the welfare claimant. The subjectifying and normalizing of welfare practices as examples of 'limit-experiences' establishes the very scourge of the so-called dependency that they are designed to remove. However, there is a paradox here. While individualizing welfare responsibility in the self of the welfare client, the social exclusion of individuals is justified as a social threat. Welfare clients are grouped into an underclass that is a 'symbolic rather than an actual institution, capable of serving at a discursive level as a repository for those whom society would segregate or exclude' (Dean and Taylor-Gooby, 1992: 45).

\section{(iii). Dependency: The Need for Choices.}

Within this aspect fall all the understandings of dependency associated with what Fraser and Gordon (1994a, 1994b) describe as the movement from the 'natural and proper' usage of dependency, in the industrial age, to a post-industrial usage where all aspects of dependency are described as 'avoidable and blameworthy'. This follows the change in the status of welfare claimants and how need and dependency are legitimated or denied. 'Security' can no longer be seen as an attribute of any social arrangements but 
is tightly aligned with individual risk and the need to manage that risk independently. Rhetorics of risk have been reconstructed to reflect the generation of a personal focus on autonomy and survival. As a consequence, this emphasis on personal responsibility is set against the obverse that welfare dependency within a market welfare society be inscribed as personal failure (c.f., Hewitt, 1992; Leonard, 1997; Rose, 1999; Shipley, 1991; Squires, 1990).

The new language of legitimization and access, intrinsic to the neo-liberal welfare society, does not rely on discourses of authority about needs and deprivation but on those of surveillance, performance and accountability (c.f., Boston et al. 1996). As a result, the normative 'clamour' about needs and rights within classical social policy writing (c.f., Titmuss, 1970, 1974) has not found much sway in current neo-liberal justifications for a welfare society (c.f., Leonard, 1997; O'Brien and Penna, 1998a, 1998b). Fraser points to the change in the language of welfare discourses from obligation and citizenship entitlement to individual accountability and performance of the welfare claimant. Her work demonstrated the value of an approach to the analysis of welfare policy that critically examined the function of discourse. Together with Gordon she analysed a 'genealogy of dependency' as 'inscriptions of power' and developed a schema of 'keywords' that typified discourses that shape the modern welfare state (1994a, 1994b). As Foucault argues, 'language is not borne against a background of silence; it is borne against a background of discourse' (Veyne, 1997: 177).

Fraser's ground breaking work on the function of discourse within welfare theory marks the first detailed attempt to redirect the focus of critical theory so that it consider the function of language in shaping the social policy climate. She identified 'expert', 'oppositional' and reprivatization discourses as those that construe the overall rhetoric favouring a minimalist welfare society $(1989 a, 1989 b)$. These discourses of expertise and privatization are crucial to neo-liberal welfare politics in that they further set out the legitimation of access to the services that a minimalist welfare society is prepared to deploy (c.f., Drucker, 1969; Shipley, 1991).

Access criteria were previously interpreted through the professional decisions of social workers based on the criteria of citizenship entitlement. That welfare state system depended upon interlocking systems of bureaucratic authority that mandated the 
separate professional authority of social workers (c.f., Rose, 1999). The complex rationalizations that shape current discourses of legitimation within contemporary welfare policy reflect aspects of Foucault's 'limit-experience'. They reinforce an expert body of discourse that bears little relationship to the actual lived lives of those on welfare.

A new ethical and cultural subjectivity is required of those on welfare. 'Poverty and many other social ills are cast not in economic terms but as fundamentally subjective conditions ... For community requires all to act by the ethics of virtuous selfresponsibility' (Rose, 1999: 265).

This work of Fraser's dovetailed with that being done by Hindess (1996a, 1996b, 1997a, 1997b, 1998b), O'Malley (1996, 1999) and Rose (1996a, 1996b, 1999) on governmentality. However, this 'is not to say that language and vocabulary of rule should be accorded a causal priority in analysis. It is simply to hold that we should not underestimate the role of language in constructing worlds, problems and persons as governable entities' (Dean, 1999a: 64). An over-reliance on such normative injunctions (or 'ideology critique') weakens Fraser and Gordon's research, as indeed all those that depend too rigidly on similar forms of normative 'scolding'. His point is that such critique 'still regards language as a second-order phenomenon shaped more by fundamental forces and conditions'. It has ignored the function of discourse.

The epistemology of much of the traditional social policy literature focused on the tangibility of needs and deprivation and had little patience, or ability, to counter the forcefulness of such discourses about risk. Indeed it had little theoretical respect for discourse analysis itself as a means of reflection (O'Brien and Penna, 1998a: 124-128; c.f., Glennerster, 1988; Offe, 1996; Osborne, 1998b; Taylor-Gooby, 1993). Nonetheless, this 'linguistic-turn' in the discourses about welfare dependency 'demonstrates the fruitfulness of attention to the language of social problems, to the way the terms of that vocabulary are contested, and to ways in which they change over time' (Dean, 1999a: 63). Exposing the limits of these anti-welfare discourses demands that we 'disrupt [the] relations of domination' that are reflected in the arguments that to be in need of welfare assistance reflects such personal failure (c.f., van Krieken, 1996: 215). 


\section{Linguistic Paradoxes: Silence, 'Side-Effects' and Knowledge}

There is a particular reflexiveness inherent in this anti-welfare rhetoric, that demonstrates how all discourses shape that which can be affirmed against the obverse of that which is denied, excluded or even that which is unable to be discussed at all. Katznelson argues that it is the power of the unspoken, the silences in the social policy debate which dictate current realities and future possibilities. As Deleuze similarly argued, 'we have to break open words or sentences, too, and find what's uttered in them ... [as] language is always unstable' (1995: 96). If we are to 'disrupt relations of domination' and expose the rationalizations of 'limit-experiences' we must:

... explore the construction and changeability of the always present division between the domains of political speech and political silence. By making this problem the centrepiece of analysis, we can widen the domain of empirical studies, make a place for counterfactual analysis, and develop a taste for thinking about possible worlds that are not very far away, but seen to be just beyond our grasp. (Katznelson, 1986: 325)

Language is not merely expressive but is also selective and in the hegemony of particular discourses we note that there are things which cannot be said and controls are exercised over who may actually represent these ideas (c.f., Moussa and Scapp, 1996). Consequently, specific political agendas are always arbitrary because they represent a selection 'from the universe of the possible'. This selection reflects how selected discourses limit and construe possibility so that what might be explained is taken for granted as reality - the neo-liberal epithet that 'there is no alternative', for example. Pejoratively, this pivots around the assumption that each protagonist has the 'facts' while the antagonist has only 'beliefs'. However, all political systems have boundaries 'between that which is discussed and disputed and that which is not discussed and disputed' (Katznelson, 1986: 310-311).

Any attempt to take issue with the strength of current neo-liberal welfare policy must start with a respect for the power of its ability to restrict the public debate - to enforce those silences which are constraints on what it is possible to discuss. Arendt has argued that analysis about public meaning and legitimate social behaviour is constrained by another aspect of 'silence'. This is not the silence that controls the acceptable boundaries of the public debate, but the silence that comes from an inability to talk about the 'good'. Arendt (1959) makes a distinction between wisdom and goodness and suggests that only wisdom can be openly discussed. Whenever goodness, or the good act, is discussed it ceases to be good. It becomes reified into a quality of the actor 
rather than the act. When this occurs Arendt suggests that goodness is destroyed, that it can be done but never discussed. As she says:

Only goodness must go into absolute hiding and flee all appearance if it is not to be destroyed ... The man, however, who is in love with goodness can never afford to lead a solitary life, and yet his living with others must remain essentially without testimony ... good deeds can never keep anyone company; they must be forgotten the moment they are done, because even memory will destroy their quality of being good. Moreover, thinking, because it can be remembered, can crystallise into thought, and thoughts, like all things that owe their existence to remembrance, can be transformed into tangible objects which, like the written page or the printed book, become part of the human artifice. Good works, because they must be forgotten instantly, can never become part of the world; they come and go, leaving no trace. (1959: 67-68)

Many of the problems that social service professions have discovered in researching and establishing the validity of their work can be attributed to the 'silence' that must accompany the good act. The distinctions that were drawn between public and private worlds are no longer viable. Arendt, prefiguring the later development of feminist theory, argued that the current conception of government, where the only thing people have in common is their private interest is false. She assumed that it was this contradiction between private and public that extinguished the difference between the private and public worlds and merged both in the social (1959: 61).

Public choice theory depends on the maintenance of a rigid distinction between the public and the private. Nevertheless, in its advocacy of the pre-eminence of the market it redefines that dualism. The essential distinction is no longer between private and public knowledge but between success and failure where success is defined as the ability to command sufficient resources to maintain a defended 'private realm'. Such defensive and protective arrangements are attempts to demonstrate that the private is not submerged in the 'social'. The contrast, typically, is variously between 'winners and losers', 'players and non-players'. The power of this harsh view of human nature depends on the ascription of 'honour' to the individual who triumphs, and 'shame' to those who do not succeed (c.f., Rose, 1999).

Consideration of the elusive silences of social policy allows us to comprehend why so many social programmes (so full of good intent) have become implementation failures. Rational explanations for such failures are unsatisfying, precisely because they ignore the irrational and the paradoxical. The use of the plural is significant. Foucault argued that there is 'not one but many silences, and they are an integral part of the strategies 
that underlie and permeate discourses' (1990: 27). He posed the dilemma that language could not fully represent that which it described. Indeed it was crucial to his argument to posit the 'difference between language and discourse' (c.f., Rajan, 1998: 450). As White argued:

To assign to language, therefore, the task of "representing" the world of things, as though it could perform this task adequately is a profound mistake. Any mode of discourse is identifiable, then. Not by what it permits consciousness to say about the world, but by what it prohibits it from saying. (1973: 32)

Reconsidering the power of the unspoken (the silences), the occluded, is not typical of social policy theorizing. Nevertheless, it is these silences that dictate current realities and construe future possibilities that social policy needs to consider. For Foucault the 'task of speaking the truth [and challenging these silences] is endless' (1984h: 31). He often suggested that in 'speaking the truth' we were looking in the wrong places! For example, he said of his overall 'project' that 'where no word is heard any more one can still hear the deep buried murmur of meaning, that what men do not say is a continuation of their speaking' (1991a: 61). It is so easy to dismiss such pejorative statements as being an intrinsic aspect of florid and fanciful French thought (vide Hacking). However, consideration that our 'meanings' and 'knowledges' refract denials as well as assertions does open the possibility that they be examined as 'practices' and not be seen as 'truths' or irreducible common sense.

\section{'Fictions' and 'Truths'}

One of the more outrageous comments that Foucault made was to suggest that truth and fiction were intimately connected. For example, it 'seems to me that the possibility exists for fiction to function in truth, for a fictional discourse to induce effects of truth' (1980a: 193). He would not exclude the function of irrationality in shaping the rationalizations and subjectifications of specific discourses. The 'speaking' to us in 'fictions' that Foucault does in order to 'induce effects of truth' challenges our perceptions of the normal. His prose, maddening to some, is suggestive of those elements of how we might 'revision the social' that lies outside of our intellectual grasp.

In a preamble to the important interview that Foucault had with Ewald, in which these comments were made, Patton suggests that understanding what he meant by these allusions demonstrates that he deliberately applied such stratagems to challenge the 
classical notion of received truth. It is another 'gauntlet' flung at the feet of the 'universal intellectual'! What Patton elucidates is that Foucault's 'regime of truth' is not:

... an epistemological function, one which would define the set of statements which correspond to reality, but ... a sociological one encompassing those sets of statements which circulate and function as true within the society. These are the discourses which have the authority and action-guiding function of truth. (1984:21)

What Foucault suggested is that we are constrained by the classical view of 'Truth' as allied with specific utterances. He set out this argument at the beginning of The Archaeology of Knowledge (1972) in his critique of an over-reliance on 'texts'. That view of 'Truth' has dictated our perceptions of what is appropriate social analysis. It takes us back to his fundamental contention that what we say is the truth (in our social depictions) must be set against the 'relativity of the truth-effects produced to the discursive apparatus deployed, and to point to the specific character of those effects' (Patton, 1984: 23). This is yet another refraction of his concept of the normalizing function of 'limitexperience'.

Foucault had an 'uncanny ability to invent whole fields of investigation'. These new areas of social inquiry came from his 'everlasting effort to formulate otherness and heterodoxy without domesticating them or turning them into doctrine' (Said, 1991: 5-6). Goldstein, echoing Said, reflected on Foucault's significant insight about 'rarity' or 'scarcity' and how this implies that our 'speaking' can never be finished. It is another example, or perhaps more accurately, a refraction of his concept of 'limit-experience'. This is 'the postulate that everything that it is possible to say, in terms of the rules and lexical resources of language, is not in fact said; that the field of utterances ... is spotty and full of gaps' (1984: 171-172). Postmodern theory might well create the legitimization of difference and destroy the basis for normative epistemology but it does not, as Foucault argued, destroy the search for the 'other'; the elusive 'non-knowledge' that is not antagonistic.

Foucault's idea that there might be a 'deep buried murmur of meaning' which is not reducible 'to language and speech', suggests that knowledge of the 'social' is most likely to 'be discovered lurking in signs and discourses' (Said, 1991: 5). This seems to find an echo in Katznelson's 'silences' in the sense that no matter how sophisticated our social knowledges, no matter how certain the findings of our social research, there is a 'more' we might yet understand. That 'more' comes from our awareness of the discursive 
grounds on which we base our social analyses. What Foucault is doing in pointing us toward the importance of such analyses is not to destroy the possibility of social theory but to make it reflectively 'honest'. His commitment to genealogy and 'to a localised and perspectivised conception of truth' allows him, Patton suggests, to insist 'on the importance of changing the forms in which we think, with an assertion of the need for a constant regard for the truth' (1984: 23; c.f., carlos jacques, 1991).

We can apply his ideas about 'limit-experience' to understand that there is a moral quality to what Rose referred to as the 'apparently 'a-moral' language of the market' (1996a: 331). The forms of rationalization, contained within in the market rhetoric of risk that shapes current discourses of welfare, are part of a specific political rationality. They cannot, by definition, argue that the policy prescriptions that typify welfare policies are somehow immutable or that they lie outside the particular controls implicit in the discourses that are used to justify them. They always involve the configuring of an 'imagined territory', and are 'the subjects of allegiance to a particular set of community values, beliefs and commitments' (Rose, 1996a: 331). Considering the forms of rationalization, implicit in the 'limit-experiences' of current welfare policies, reveals the configurations of that 'imagined territory' and how it shapes the driving rhetoric of these discourses about the pre-eminence of a welfare society. Exposing the hidden or silent moralities of these 'mentalities of rule' is a valid function of social policy critique.

\section{The Welfare 'Gaze': Risk and The Dilemmas of Dependency}

Foucault argued that the imperative for such discursive control, and the corresponding maintenance of that 'imagined territory', was possible because 'power is tolerable only on condition that it masks a substantial part of itself'. This is the basis for the hegemony of neo-liberalism where political substance is 'masked' in various rhetorics of common sense. As he continues, the force of such hegemony 'is proportional to its ability to hide its own mechanisms. Would power be accepted if it were entirely cynical? For it, secrecy is not in the nature of an abuse; it is indispensable to its operation' (1990: 86). So perhaps it is not to the 'noise' of social change (the strident anti-welfare rhetoric) that we must look for understanding but to the 'silences'. What is it that contemporary political and social debate defines as the vital issues, and how do these obvious concerns relate to those imperatives that are not framed as part of public discourse? ${ }^{\text {li }}$ 
Unmasking these assumptions that dominant political power 'hides itself' exemplifies Beck's argument that 'the institutions of industrial society become the producers and legitimators of threats they cannot control' (1992: 5). Risk society, he suggests, has two important aspects. The means by which cumulative decision-making produces a sense of residual risk and, perhaps more importantly, how the perceived dangers of modern society become the dominant aspect of public social and welfare discussions. In The Birth of the Clinic (1973), Foucault suggested that an essential aspect of medical 'gaze' (or surveillance) was to be able to 'look with knowledge' upon another. The looking was not so much a discovery but a confirmation, an attempt to prove what was already known. For Foucault, the 'gaze' was 'master of its truth' (Miller, 1987: 147; c.f., Wendt, 1996). Similarly, the 'welfare gaze' presupposes a knowledge that needs no looking; it already contains what he importantly and elliptically called a 'speaking eye'.

There is no discovery to be made. By virtue of being in a state of need the welfare claimant is already 'known' as dependent (c.f., Moussa and Scapp, 1996; Taylor-Gooby, 1993). The 'welfare gaze' therefore is contained within the process of how we define our responses to need. To seek public support is to define the self as needy, and by definition, to be dependent (Leonard, 1997: 54-59). Even further it is to define such dependencies as malign and those who express them as abject (Rose, 1999: 253). For example, with the growth of third and fourth generation welfare dependent families 'dependency relationships are enculturated into social habits and identities' (Wynne, 1996: 51). Leonard discusses the emergence of what is pejoratively called a 'culture of poverty' and how this has been reified into the harsh rhetoric attacking all forms of welfare dependency (1997: 50-54; c.f., Dean and Taylor-Gooby, 1992; Rose, 1999). The issue here is the yawning gap we create by distinguishing between the independent and dependent. As Castel comments:

Instead of segregating and eliminating undesirable elements from the social body, or reintegrating them more or less forcibly through corrective or therapeutic interventions, the emerging tendency is to assign different social destinies to individuals in line with their varying capacity to live up to the requirements of competitiveness and profitability. (1991: 294)

Welfare recipients have become a vilified 'population'; subjective experiencing is reified into 'fact'. Similarly, the welfare state created, within the notions of citizenship responsibility, the boundaries of the 'welfare-gift'. Welfare recipients were expected to 
have some reciprocal responsibility (to get well, to look after themselves or their families better, to seek work, etc.).

Citizenship theory posed similar issues of a mutual knowing based upon an acknowledged inter-subjectivity (there but for the grace of God go ). But with the new ethos of individual risk and the paramount cry of self responsibility there can be no real exchange, therefore, between the autonomous and the dependent, except that of disdain (c.f., Rose, 1999). Welfare recipients, seen as a group, are regarded as 'an antisociety, a zone of unchecked instinct incompatible with any truly social being' (Gordon, 1991: 38). The only acceptable form of 'reciprocity' is not to be in a state of dependency. The pendulum swings against the poor. The double bind of welfare is struck: welfare recipients ought not to need that which demonstrably they do need.

Foucault's antipathy to the possibility of any universalizing structures cuts both ways. Anti-welfare rhetoric, which generalizes and stigmatizes welfare clients, represents an attempt to forge a 'common footing' (an identity of success) that is separated from failure and risk encapsulated in the survival claims of welfare applicants. But if Foucault is correct, such anti-welfare rhetoric must be seen as expressing something particular and contingent, and not immutable. There is no 'universal, guaranteed, verified or grounded' common footing from which to judge. The passion for change, to articulate a positive view of the world, now intersects with a passion for protection from the ill consequences of invasive risk. Thus the notion of risk emerges out of the search for 'subjectivity as the root of a positive self'. It is this search for autonomy, within market-based neoliberalism, that establishes risk as a separate category of possibility.

The search for a positive philosophy of the self has recursively set out to deny the 'other' who inevitably becomes a 'competitor' and not a 'companion' in the avoidance or minimizing of risk. It is the 'politics of ourselves' that shows how various attempts to establish the ground of a positive, subjective, non-sacrificing self, have resulted in various arguments for self-autonomy. However, the 'politics of our selves' has been derailed by a preoccupation with risk. It is this that drove the separation of risk (qua security) from its association with the social and allied it with individual protection. The rhetorical strength of such arguments, as Hacking has suggested, depends on the 'cunning of conscience and self-knowledge ... to make it feel private' (1986b: 236). 
Speculation that the 'self is nothing else than the historical correlation of the technology built into our history' raises the spectre of a contingency that is, seemingly, too hard for us to bear.

Foucault's thinking about the 'self' is not entirely consistent. In his early work it seemed that he was concerned to 'free the self' from the consequences of disciplinary governance. However, in his later work he did turn explicitly to describing how a new 'ethics of the self' was possible. He saw the prospect of an ethics that is 'no longer supported by either tradition or reason; as an artist of itself, the self would enjoy that autonomy that modernity can no longer do without' (Veyne, 1993: 7). However, it is an autonomy that is set against a context of constant risk. It magnifies a counter-defensive self-regard that finds risk at every turn since it is now the perception of risk that is intrinsic to the minute observation of the self. As Osborne has argued, "the ethic of altruism related more to the establishment of a particular motivation towards conduct than to an overriding moral demand for altruistic virtues as such'. It was an essentially internal individual process so that what 'mattered was the relation to self established by the ethical labour of altruism' (1998a: 230).

\section{Conclusion}

Foucault's genius was to see previously unforeseen linkages between disparate aspects of how we undertake historical and social analysis. He linked the subjectification of the practice of confession to what he called the 'shimmering mirage' of philosophical assumptions. Those that seek the 'fundamental relation to the true, not simply in oneself - in some forgotten knowledge, or in a certain primal trace - but in the self-examination that yields, through a multitude of fleeting impressions, the basic certainties of consciousness' (1990: 59-60). The practice of confession creates the trust and expectation of a teleological truth - ideas which are 'lodged in our most secret nature' and which are experienced as 'demands' that must surface. The neo-liberal 'will to knowledge' that led to an ethic of self-responsibility grows out of this process of selfexamination. It is the individualizing of confession that creates the internal reflective mechanism that seeks the 'fundamental relation to the true'.

Foucault's understanding of this leads him to argue that the practices of such power cannot therefore represent the politics of the present. We are not, within these 
assumptions, able to examine the present because the present is always being constructed from the 'certainties' of a primal past. That this represents the precise nature of a 'will to knowledge' is his basic assumption. For example:

Confession frees, but power reduces one to silence; truth does not belong to the order of power, but shares an original affinity with freedom: traditional themes in philosophy, which a "political history of truth" would have to overturn by showing that truth is not by nature free - nor error servile - but that its production is thoroughly imbued with relations of power ... One has to be completely taken in by this internal ruse of confession in order to attribute a fundamental role to censorship, to taboos regarding speaking and thinking. (1990: 60)

While the power of these arguments about bio-power was forged in Foucault's impassioned treatise about sexuality, extrapolating the method of his analysis to this consideration of risk, social welfare and dependency within social policy is defendable. It will require a research focus that does not see specific categories of dependency as if they were 'contingent upon changing social structures'. They should be seen as aspects of governmental practices of welfare and must not be considered as if they were just 'components of ideology' (Dean, 1999a: 65-66).

There can be little dissent that the structures as well as the rhetoric of welfare do not promote genuine freedom and are inevitably part of the discursive disciplinary functions of a post-welfarist society. The on-going reflections within sociology and social policy about Foucault's thesis of governmentality do provide critical opportunities to examine the whole 'welfare project' (c.f., Rose, 1996a, 1999). His arguments for a genealogy of madness, criminality and sexual identities can equally be extended to welfare and poverty issues (c.f., Procacci, 1989, 1991, 1994). How they reflect the forms of rationalization that he argued was intrinsic to his analysis of 'limit-experience' is one focus of theory development within social policy. His work about discourse analysis does provide 'the first formulation of [a critical] ... rhetorical consciousness' (Korsten, 1998: 66) and a method with which to analyse the function, rather than the ideological intent, of welfare rhetoric. Fundamentally, his analyses involve the how of actual practices, and not the why of the rhetorical criticisms of them, and serve to emphasize the discourses that support particular practice. 


\section{Chapter Seven}

\section{Welfare Governance: Practices, Paradoxes and Possibilities?}

Nothing is more inconsistent than a political regime which is indifferent to the truth; but nothing is more dangerous than a political system which claims to prescribe the truth. The function of "speaking the truth" should not take the form of law, just as it would be futile to believe that it properly belongs to the spontaneous play of communication. The task of speaking the truth is endless: no power can avoid the obligation to respect this task in all its complexity, unless it imposes silence and servitude. (Foucault, 1984h: 31)

How we assess Foucault's relevance to social policy per se must respect the pattern and intent of his work generally - namely, to demonstrate the forms of rationalization that shape our politics, what we define as proper knowledge and how we depict 'truth' (1991d: 70 ff.; c.f., Connolly, 1993b). The possibility of 'freedom', and the 'endless task of speaking the truth', as he contended, must begin with an awareness of the actual practices of our present politics, not from some revamped exposition of normative oughts or any new compelling epistemology of the possible. He cannot be expected to provide a new critical paradigm for how modernity and its discontents might be resolved, since that was never his aim. Such searches were always, he thought, wistfully illusory (c.f., 1991d). He saw 'the dark side of every step towards the light'. He was acutely aware of 'the price at which every advance had to be bought'. And, moreover, as Nehamas continued, Foucault 'believed that the price was never a bargain' (1998: 169170).

This chapter explores how we might apply Foucault's work to enhance the idioms necessary for a critical social policy. It also examines what it means (and indeed whether it is ever sustainable) to develop 'social' arguments from his work. It would be facile, however, to presume that Foucault was intrinsically a 'social theorist'. No matter how we might apply his ideas in relation to the development of social policy theory we cannot call on him to play the role of the 'legislator or the prophet'. But only how we might use his ideas to disrupt 'regimes of truth' (Smart, 1983: 82). As he expressed, in his own idiosyncratic prose, such a critical knowledge 'discovers the violence of a position that sides with those against those who are unhappy in their ignorance, against the effective illusions by which humanity protects itself, a position that encourages the dangers of research [sic] and delights in disturbing discoveries' (1984c: 95). 
His apparent pessimism about progressive social change is a profound reflection perhaps indeed an injunction - to examine and possibly 'disrupt' those patterns of knowledge that determine the subjectifications and limits, in this instance, of welfare 'politics'. Throughout this exploration of 'limit-experience' in relation to social policy I have emphasized the following questions:

- What are the rationalizations we use to defend our present?

- How do we determine what is an objective analysis of welfare when the forms of that 'knowledge' are actually agreed limits on what may be known?

- How have the social and the economic registers been elided?

- Can this be related to the structural dilemmas of the welfare state that Foucault depicted (1981b: 253-254)?

- How reasonable is it to assume that we can shape a welfare ethics that respects the freedom and autonomy of welfare 'recipients/clients'?

- How were the former social technologies of mutual obligation that shaped the rationalities of welfare states transmuted into the competitive individualized technologies of a market-oriented welfare society?

Approaching these discursive facets of welfare politics as specific examples of 'limitexperiences' we can more clearly reflect how current policies actually construe, constrain and constrict political, personal and social options. The investigative questions that social policy formerly considered integral to its critical analysis involved the assessment and administration of universal and institutional controls - particularly how we might say that we were governed in the name of a common citizenship.

These welfarist 'mentalities of rule' - the ways in which the 'thought involved in the practices of government is [deemed to be] collective and relatively taken for granted' (Dean, 1999a: 16) - have no cachet. The government of those 'on the welfare' now implies quite separate controls and expectations intrinsic to an active neo-liberal society. The question, how will we ever respect the life politics of those on welfare, is particularly apt given new possibilities of governance in an era where mapping of the human genome has the potential to revamp appreciably our expectations about how we will control human behaviour (c.f., Rose, 2000).

Some of the nascent questions about the globalization of social policy are discussed, as is the discursive function of the notion of a continuing welfare state crisis. Both of these themes are related to the issues of the death/decline of the 'social' (c.f., Rose, 1996a, 1999). These topics are related to the shift in welfare governance from support for a universal and redistributive state to how a minimalist welfare society, crafted as a social 
safety net, has become for many Western democracies the dominant motif of their welfare policies. Osborne's respectful but ambivalent reaction to the idea that Foucault could have any relevance to sociology and also, by abstraction, to social policy theory is revisited as a reflective coda on the enduring impact that Foucault has had within our history of ideas.

\section{Governing Poverty and Ordering Welfare}

Applying Foucault's ideas to those areas of our social world where social policy traditionally staked out its area of expertise we can see two major influences; the question of welfare as a discourse and welfare as a practice. Both are capable of being examined within the perspective of governmentality. As Hindess has suggested:

People can be expected to be appropriately well-behaved only if their conduct is substantially and effectively governed in other ways - most especially through acquired habits of self-control ... reinforced by the normative gaze of others and in the work of a variety of state and non-state agencies ... This ... marks one of the most important differences between the Foucauldian treatment of liberalism as rationality of government and its more conventional treatment in political theory as an ideology or normative political standpoint. Where the latter presents liberalism as focusing primarily on relations between rational; and morally autonomous individuals and their government, Foucault regards it as focusing on the multiplicity of ways in which individuals, groups and organizations within the population are subjected to government of their conduct, by state and non-state agencies and, of course, by themselves. In this later perspective the freedom of members of the governed population is seen as an artefact of effective government. (1997a: 263)

That the various competing rhetorics of welfare staunchly defend their separate policy positions is obvious. How to seek either rapprochement or change is not so clear. The traditional concerns of social policy emphasized the themes of citizenship rights, universality and social justice. However, concentrating on social justice as an organizing principle has been a 'disturbingly open-ended strategy for social policy' because it has not accepted the limited and practical mechanisms by which social governance has historically constituted its objectives and procedures in the modern West' (Burchell, 1995: 44).

Rethinking the former idioms and practices of social policy theory raises the problem that this normative focus, and its patient empiricism about social need and disadvantage, construed the typical patterns of critical discourse and how it was expressed. It was a 'veridical discourse' because it fashioned 'institutional practices or governing practices, i.e. practices that organize and codify ways of doing things such as curing, relieving, 
administering, punishing, etc., and that involve the government of conduct, whether of self or others' (Dean, 1992: 216). These normative inscriptions - codified expectations about citizenship entitlements and social rights - have taken on the modern form of proof-texts. Various welfarist discourses have fashioned such ideas as if they were intrinsic and immutable. Nevertheless, while laudable, progressive and adhered to as an ideal once removed, they were ineffectual in countering the market-rationality of our present neo-liberal regimes. That powerful rationality 'appears to found its own personal morality, one that it never ceases to extol, and one that seems inscribed in the contours of our life-conduct' (Dean, 1992: 244). It is certainly not one that accepts the 'social legitimacy' of need or respect that failure is an intrinsic aspect of the life-cycle (c.f., Malpas and Wickham, 1995).

Any substantive development of a Critical Social Policy will have to find new theoretical justifications to articulate the currently unfashionable but vital safeguarding 'of basic needs, as well as opening up opportunities for different individuals and groups to encounter the otherness of need in each other' (Hewitt, 1994: 54). It will require us to consider whether so many of its determining idioms about justice and rights are in reality artefacts of government - conduct that is vouchsafed by the tangible practices of governance. While Hewitt's respect for the notion that there are still 'common human needs' is an enduring theme within traditional social policy it now has to 'ply its trade', so to speak, in a vastly different political context than that which valorized notions of 'basic needs' or 'social justice'.

The idea of the 'social', from which the idioms and metaphors of obligation typical of former welfare states are drawn, no longer applies. The problem for social science analysis, as Procacci has suggested, is that by concentrating on poverty studies it:

... tied its fortune to an administrative state. It engaged in the political arena, playing an active role in promoting a new strategy of the "government of the social", which was at the core of the transformation from a democracy based on the rights of each into a democracy based on the duties of all toward everyone. (1989: 184)

We can apply Foucault's analyses to reveal the nature of the discourses of inevitable common sense, so intrinsic to neo-liberal welfare policy, as contingent, relative and ultimately changeable. All forms of such claims making can be investigated as examples of the 'limits' that such discourses impose on experience. His analysis of 'limit-experience' and how the processes of normalization constitute such claims of 
subjectivity demonstrates how such discourses depend upon the notion of an independent rationality. If we are able to re-examine the history of reason, in the manner Foucault outlined, we will see 'that it was born in an altogether "reasonable" fashion - from chance' (1984c: 78).

Consequently, a genealogical analysis of the procedures, practices, apparatuses and institutions of public choice and agency theory bases an inquiry into welfare policy within an 'ontology of the present' rather than an 'analytic of truth'. For example:

The principal political question today may be not to make our structures of welfare more accountable to certain moral precepts and principles, or even to continue to establish that poverty is an effect of social and economic structures and not a matter of personal failure. Rather, it may be the need to rethink the political rationality that makes such discussions necessary and their oppositions predictable and stale. It may be that we need to problematize that rationality that constitutes poverty as a necessary part of our forms of life. (Dean, 1992: 244-245)

The purpose of constructing such a possible Foucaultian genealogy of welfare policy is not just to frame new arguments about the relative rights and responsibilities that ought to obtain between the powerful and the weak, or to establish the basis for an alternative politics. That has been argued over and over again. The more vital question is whether critical theory actually establishes, and reflexively reinforces, the power of that which its adherents seek to change (c.f., Rorty, 1995)? For example, we cannot, as Baudrillard argues, destroy hegemonic political systems 'by a direct, dialectical revolution of the economic or political infrastructure. Everything produced by contradiction, by the relation of forces, or by energy in general, will only feed back into the mechanism and give it impetus' (1993: 36).

What social policy theorists must be concerned about is how these new 'regimes of control', which depict welfare transactions as market exchange and not social obligation, have reinforced the pre-eminence of the private life world. It is the perception of the overwhelming fact of risk (and the rhetorical severing of security from welfare and the social and associating it only with individual risk) that has rendered immobile the public life-world. These private, individual sets of 'abstractions', have powerfully reconstructed risk and dependency, and are reinforced by a discursive style of 'ironic contingency' that vigorously disdains any recognition of mutual subjectivity that might lead to social justice claims-making. 
The universal subjectivity of dependency and vulnerability, the lot of us all at various stages of our lives (c.f., Goodin, 1985), is re-masked as belonging essentially to private discourses about risk. It is defined within the rhetorical symbols and metaphors of individual responsibility that serves the hegemonic aims of neo-liberal politics. Obligation for the satisfaction of needs has become, through the modern mechanism of governance, more a private than a public responsibility. Consequently, discourses about welfare and risk are powerfully centered on the logic of a presumed rationality that is, as Foucault argued, better understood as the 'subjectivity' of the self. However, defining the practices of this 'will to knowledge', in order to equate it with the rationalizations of 'limit-experience' has proven elusive. He found many 'forms' of rationality in knowledge; namely, 'instinct, passion, the inquisitor's devotion, cruel subtlety, and malice'. The power of these discourses of privacy is such that challenging them remains an adventurous task for social policy. For example, to 'contest or attempt to reshape ways we think about governing in any sphere, ... [calls] into question the very fabric of our forms of life' (Dean, 1999a: 65).

\section{Discovering Foucault's 'Limits': Welfare Critique and 'Limit-Experience'}

Whether social policy can apply aspects of Foucault's ideas to create new discourses about social need, in order to further its chief concerns about social equity and justice, dependency and the impartial distribution of benefits, requires two considerations. The first is whether it is possible for social policy to establish a theoretical cogency within the neo-liberal world of market governance that has fundamentally changed the patterns of such governing practices - away from static patterns of institutional management to those involving processes of 'constant and never ending modulation' (Rose, 1999: 234). We are no longer governed by institutionally based disciplinary procedures confined to specific sites. Seeking to improve the functioning of specific welfare institutions can only render a local effect. We need to understand that the new mechanisms of control, typical of a minimalist market-oriented welfare society, do not fit Foucault's disciplinary matrix. That 'world' and how Foucault perceived it has already altered. Deleuze, for example, suggested that Foucault's portrayal of 'disciplinary society' was already superseded, and that we ought to abandon the outmoded metaphor of a 'carceral archipelago', since it was 'written at the dusk of such societies' (1995: 177-178). 'ii 
The second consideration is that Foucault's ideas cannot be forced to 'work' in areas where he never intended that they should have any relevance. We have now emerged from the institutional rigidity of such disciplinary societies and we now live in societies fashioned by different patterns of control. The forces that shape this neo-liberal world have been powerfully antagonistic towards the traditional social metaphors and idioms that social policy espoused. Governmental control, the 'conduct of conduct', is no longer explicitly disciplinary but administered by processes of influence 'immanent to all the places in which deviation could occur' (Rose, 1999: 233-234). Nonetheless, while aspects of Foucault's depiction of the institutional forms of control, indicative of 'carceral society', may have been superseded the perception that the forms of government (regimes of control) that now predominate depend on constant change can still be critiqued as rationalizations of 'limit-experience'.

The crucial question is whether the very nature of how social theory was framed within social policy constrained its rhetoric to the 'disciplinary world' of the superseded institutional welfare state? Rose's contention about the decay (death?) of the 'social' and how that impacts on social policy will be discussed later. Here it is important to highlight the question that social policy, if it is to have any legitimacy to critique the newly modified 'social', will have to find new idioms for that research. That may prove illusory given the force of the analysis that sees neo-liberal welfare policy having displaced 'social policy and social government by the task of cultural reformation' (Dean, 1999a: 172).

What social policy theorists gain from Foucault are glimmerings of possibility. His ideas cannot necessarily be adduced as possible 'solutions' to the dilemmas we face in the transition from the welfarism of the welfare state to the independent, self-managing risks of the welfare society (c.f., Pratt, 1997). For example, Foucault suggests that because there are always several responses that can be made to address any one 'single set of difficulties' what we need to understand is 'what makes them simultaneously possible' (1984f: 389). Rose captures this sense of what Foucault intended here when he argued that:

We should not emulate sociologists by seeking to chart the emergence of a 'postdisciplinary' society. Rather, we should seek to identify the emergence of new control strategies and the reconfiguration of old ones. (1999: 240) 
We cannot tie Foucault to a tight periodization of his ideas. He was prepared to let them go - especially in respect of his argument that his books should be read as 'experience' books and not 'truth' books (1991d). We do need to find a different vernacular within social policy to comment on this new aspect of governance. It will require social policy theorists to think less in terms of universalizing and institutional forms of rationalization and subjectification and respect the imperative of Foucault's notion of constant experiencing and experimenting and how that shapes social science research. Social critique might well be more effective in challenging current welfare discourses if its practitioners kept this in mind!

However we social policy theorists draw on Foucault's ideas to articulate a new mandate for our concerns, we must not lose sight of his proper cautions about their application. They cannot be reinterpreted as commentary on the shape, rationalizations or conflictual policy contexts of a political 'fabric' that he never knew and didn't address. Neither can they be adduced, as Connolly argues, to force a closure to the ambiguity of politics by arguing that agonistic contest has been eliminated (1993b: 149).

Foucault always considered that his critique was unfinished and thus his ideas could only be applied to assess 'a direction for research' since he thought his own investigations about governmentality were 'rudimentary' (1981b: 253). He proposed four considerations to be noted in how that that ongoing work might be undertaken. Firstly, what he meant by power should only be interpreted as a 'certain type of relation between individuals'. He distinguished his analyses of power from those other political aspects of 'exchange, production [and] communication'. What he focused on was a view of power where 'some men can more or less entirely determine other men's conduct but never exhaustively or coercively'. This involves his notion of 'being submitted to government'. The second feature was that the forms of rationalization that he thought determined power over others differed from those 'peculiar to economic processes, or to production and communication techniques'. That implies thirdly, for Foucault, that we should examine the form of that rationality so that we can avoid subsequent institutions repeating the same rationalizations but expressed in different institutional forms. Finally, he made the point that because 'the state is both individualising and totalitarian. Opposing the individual and his interests to it is just as hazardous as opposing it with the community and its requirements' (1981b: 253-254). 


\section{The Eclipse of the 'Social' Paradigm}

Foucault's work, among others, and particularly his thesis of 'limit-experience', has undercut our reliance on the 'social' as an unquestioned political ground within which social policy traditionally articulated its values and normative social ethics. Whatever application of Foucault's ideas we can usefully make within social policy has to demonstrate how it might reflect, as well as be able to critique, the power of these neoliberal 'mentalities of rule' where the 'social':

... may be giving way to the 'community' as a new territory for the administration of individual and collective existence, a new plane or surface upon which micro-moral relations among persons are conceptualized and administered ... this is [not] merely a matter of changing professional jargon: it is indicative of a mutation, rather profound, if still uncertain, in the ways of thinking and acting that used to be conducted in a 'social' language. (Rose, 1996a: 331)

No longer does the state see the 'subjects of government' as some generalized or reified coherence of all citizens within a social fabric. The 'social' no longer represents 'an eternal existential sphere of human society' (Rose, 1996a: 329). The proper subject of government is not 'the social' but the complex networks of interaction, bargaining and compromise which interpose and counter-pose interlocking, but separate, networks of individual obligation. We cannot easily abstract from this reified de-coupling into false nostalgia for a vanished social. What is possible may be better revealed to us in understanding Foucault's challenge not to seek for alternatives and resolve problems but to delineate a 'genealogy' of problems.

This apparent stumbling block requires a new approach to social science research, a new 'analytics of welfare government' and suggests:

... a type of study concerned with an analysis of the specific conditions under which particular entities emerge, exist and change. It is thus distinguished from most theoretical approaches in that it seeks to attend to, rather than efface, the singularity of ways of governing and conducting ourselves. Thus it does not treat particular practices of government as instances of ideal types and concepts. Neither does it regard them as effects of a law-like necessity or treat them as manifestations of a fundamental contradiction. An analytics of government examines the conditions under which regimes of practices come into being, are maintained and transformed. (Dean, 1999a: 20-21)

Social policy has been recalcitrant in developing any effective response to how the 'conduct of conduct' can be challenged. We have presumed that the 'social' represented an immutable or irreducible pattern and place where we are governed as mutual citizens. The dominant patterns of social policy's research efforts depended on critiquing the welfare state as a political and social institution. Understood as a 
'disciplinary' set of procedures policies and expectations that were institutionalised in interlocking welfare bureaucracies, the welfare state constructed an ethos within which social policy theorists argued for more equitable delivery of social services. However, as we have seen it is no longer possible to 'govern in the name of the social' for the 'social', as a unique domain wherein all politics must take place, has undergone a radical metamorphosis. As Pratt suggested:

... the relationship between subject and state has had to be recast: the dependent subject of welfarism, protected from risks, and on whose behalf the state would intervene, is replaced by the juridical subject of neo-liberalism, now granted rationality and responsibility. (1997: 135)

The 'mentalities of rule' that Rose (1999) depicts as instrumental in creating our present, more as a 'regime of control' than a disciplinary society with explicit forms of institutional control, can be examined within a Foucaultian perspective.

This requires an analytics of welfare government that 'works from concrete analysis rather than general hypothesis' (Dean, 1999a: 149). It will not evaluate the practices of government against some implicit or explicit 'ideal type', nor set out to reveal 'fundamental contradictions' but rather unravel the 'limit-experiences' that arise out of the manifold ways in which 'regimes of practices come into being, are maintained and transformed' (Dean, 1999a: 21). For example, it is an important aspect of the counter dependency arguments, which neo-liberal welfare rhetoric espouses, that those in need be seen as ethically inferior (c.f., Dean and Melrose, 1999; Leonard, 1997; Rose, 1999).

Osborne, reflecting on the development of one aspect of these new regimes of welfare practice suggested that the 'ethical labour of altruism' towards the poor (and the state of poverty that informed classical liberalism) never accepted that there could be any principle of mutuality in that exchange. He argued that we are still working out one of the major imperatives of classical liberalism that separated ethical and moral behaviour. For example:

... the ethic of altruism related more to the establishment of a particular motivation towards conduct than to an overriding moral demand for altruistic virtues as such. It was the ethical work not the ideology or moral code that was important. What mattered was the relation to self established by the ethical labour of altruism ... everyone was expected to act in a moral way; but only the best could be truly ethical, since this required practices of conscience and hence a certain degree of freedom. As for the masses and the others, their destiny was to be not ethical culture but moral regulation. (1998a: 230) 
Exposing the normalizing practices of such assumptions allows us to return the demand for moral behaviour from being focussed solely on the deviant, dispossessed, dangerous and dependent to the whole. It would permit us 'to study the way that people model their own freedom and subject their freedoms to the regulation of others. It would be a move towards a critical sociology of the limits of our freedoms' (Osborne, 1998a: 233). As Foucault suggested:

... the political, ethical, social, philosophical problem of our days is not to try to liberate the individual from the state, and from the state's institutions, but to liberate us both from the state, and from the type of individualization which is linked to the state. We have to promote new forms of subjectivity through the refusal of this kind of individuality which has been imposed on us. (1983: 216)

Such an analysis would examine the 'limit-experiences' that define what is meant by specific freedoms in relation to the normalizations and rationalizations of contemporary politics. This would expose the selective practices of the morality that apportions blame to the welfare client. It would argue that all social and political discourses involve some expressed limitation of freedom.

The manner in which such research might be undertaken is only just being initiated but social policy does need to develop a language of critique that can effectively comment on how the linguistic 'anchors' of risk and security have been shifted away from the state as common guardian to the individual as an active participant in the managing of their own risk. It needs to relinquish its dependence on institutional idioms that do not reflect the present market reality and that cannot adequately explain the shifts and processes of 'regimes of practice' that develop out of the pre-eminence of the market and the relentless demands for new 'freedoms'.

Paradoxically, what we have now is a control society, as Rose suggests, that does not respond to individuals as 'subjects with a unique personality that is the expression of some inner fixed quality, but with elements, capacities, potentialities'. The emergence of a deregulated market-based society has changed the pattern of how wealth and goods are distributed and weakened those arguments that posited the legitimacy of 'social' distribution. We are no longer socialized against some pattern of institutionalized norms, and we do not have to deal with the same patterns of surveillance and subjectification that shaped the expectations of 'appropriate' citizenship requirements typical of welfare states. As Pratt argued: 
... welfare strategies and modalities of governing seemed to constitute an overintrusiveness, an over-regulation of the personal lives of its subjects - hence the developments to reduce the "moral guardian" role of the state. But from there on, welfarism seemed increasingly unable to meet the social expectations it had raised. (1997: 132)

Patterns of surveillance are not imposed externally but are part of the very shape of what is defined as acceptable conduct. With the eclipse of welfarism, and the emergence of Rose's citizens who are 'active in their own government', we observe that our conduct 'is continually monitored and reshaped by logics immanent within all networks of practice'. Benign impulses are optimised and malign impulses minimized through a complex system of dispersed political powers (Rose, 1999: 234). Rewards are allocated through new patterns of control and inclusion involving the constantly fluctuating processes of 'choice, autonomy, and consumption' (Rose, 1996a: 344). Rose develops his observation further and argues that 'civility is understood as affiliation by consumption, dividing practices are re-configured to problematize certain 'abjected' persons, sectors and locales for specific reformatory attention: the underclass, the excluded, the marginal' (1996a: 345).

\section{New Territories of Government}

The genius of neo-liberal politics and globalized capitalism has been to destroy the presumption that the 'social' is necessarily coterminous with national boundaries (c.f., Mishra, 1999). Not only has the 'territory' of governing changed but also the patterns of political control intrinsic to the idioms of sovereign and independent nation states. While Foucault's ideas about the carceral society still warrant our consideration they do need to be recast in the light of these changed depictions of the forms of governance (c.f., Osborne, 1999). Though governments still control their specific populations with the 'territorialized political machinery available to them' that does not now require the same political arrangements that social policy typically relied on to articulate its themes of social protection, justice and rights within the consensual politics of social solidarity.

Changes in welfare governance have required social policy to relinquish any dependence on normative and generalizing arguments that reflected an over-reliance on Foucault's idioms of disciplinary society:

The human beings who were to be governed - men and women, rich and poor - were now conceived as individuals who are to be active in their own government. And their 
responsibility was no longer to be understood as a relation of obligation between citizen and society enacted and regulated through the mediating party of the State: rather, it was to be a relation of allegiance and responsibility to those one cared about the most and to whom one's destiny was linked. (Rose, 1996a: 330)

How the 'new economy' works does not reflect the patterns of analysis - those normative rationalizations of the 'social' - that typified traditional social policy (c.f., Titmuss, 1974). Citizens are no longer solely governed in terms of their physical space or their territoriality. The 'economic fates of citizens within a national territory are uncoupled from one another' and the social claims of citizenship are voided.

The nation state no longer confers and institutes automatic rights of 'social' citizenship. The qualities of good citizens are 'a function of their own particular levels of enterprise, skill, inventiveness and flexibility' (Rose, 1996a: 339). It is more an activity than a status.

Effective political power can no longer be assumed to be located in representative governments alone. It is dispersed - shared, negotiated and contested by diverse agencies at the local, regional, national and international level. (Tully, 1999: 178)

Citizenship rights and obligations, which were the natural expression of the former civil society, can no longer be so uncritically articulated. Whether such theorizing about citizenship is now really possible is significant (c.f., Hindess, 1997a). Certainly if it is feasible it will increasingly be seen to represent 'claims' against a self-referent 'community' and not the state. Rose has summarized this 'mutation' in political language whereby the social is transmuted into community 'as a new territory for the administration of individual and collective existence'. The essence of his argument is that there has been a 'complex reconfiguration of the territory of government' (see also Garland, 1997). This territory embodies radically different 'political languages' which suggest that political issues will not be resolved on the basis of the nation-state, as such, but:

$\ldots$ in terms of features of communities and their strengths, cultures, pathologies. They shape the strategies and programmes that address such problems by seeking to act upon the dynamics of communities. (Rose, 1996a: 331)

Society as the pre-eminent focus of politics is voided by the assumptions that support such 'collectivities' - what Hindess describes as 'the rationality of faction' (1997a: 263264). Bauman has also suggested that this new focus of governance occurred because the 'nation-state proved to be the incubator of a modern society ruled not so much by the unity of feelings as by the diversity of unemotional market interests' (1997: 192). 
What concerns many defenders of citizenship entitlements and rights is that these newly self-referent 'communities' liii appear to indicate 'that there is no longer a representing or representative consciousness in politics' and therefore no way to recognize the legitimacy of a 'pluralization of social victims' (McNay, 1992: 190). As privileged groups, their conduct shaped by consumption and markets, these new political groupings can now comfortably stand outside the political struggles of the 'excluded' or the 'dispossessed'. They seek to govern through their newly found sense of freedom and not through any sense of civil society, imprisoned with the 'baggage of obligation'. The 'social', in this view, cannot really be postulated.

\section{What Manner of Foucaultian Critique?}

We can apply Foucault's ideas to critique modernity from within where they serve an agonistic purpose. However, his ideas and methods can be consigned too easily or quickly to a 'place' where they are considered clever but too idiosyncratic or esoteric for the 'practicalities' that social policy theorists assumed was the proper focus of their inquiries and that they ought to address. Applying his ideas to comment on the modern welfare society requires a 'renewal of interest in the role of historians of the present as public intellectuals', that is to say that they regard critical commentary as being part of their social responsibility. It also requires a 'conceptualization of politics as relations of contest or struggle which are constitutive of government rather than simply a source of programmatic failure and (later) redesign' (O'Malley et al., 1997: 505).

We can use his ideas to examine the possibility of a new theoretical language in social policy, although that task will not be easy given his stricture that the 'emergence of social science cannot $\ldots$ be isolated from the rise of this new political rationality'. This, he argued, 'results from a constant correlation between an increasing individualization and the reinforcement of this totality' (1988b: 162). It is the detail of this that we need to convey. His point, which he made often, was that social science must confront its role in the 'mentalities of rule'; it cannot stand outside for it is part of the governing process.

If social policy is to play any part in this it needs to reinvent the idioms of its critical language. The metaphors of normative injunction has 'held' social policy in definitions of research and critique that are stubbornly committed to patterns that derive from its former reliance on the idioms and practices of institutional welfare analysis. These are 
often expressed in universalistic terms, reflecting the long socialist and social democratic tradition of earnest proposals for social justice and social inequality. It demonstrated a dual function, how the 'human sciences of our time' have been both positivistic, pursuing an idea of value-neutrality, and eschatological, pursuing the idea of social redemption (White, 1973: 43). However, social services are no longer delivered to people in need as if they are solely 'beneficiaries' of the state. The culture of these fiscal transfers has fundamentally changed and a more 'active' and participatory response is demanded of those 'on the welfare'. For example, as Dean argued:

$\ldots$ it is no longer enough to provide services and expertise to assist the unemployed to exercise their freedom on the labour market: access to such services and expertise must take the form of a market so that the unemployed can learn to exercise their freedom on such a market as consumer. (1999a: 172)

In addition, the policy mechanisms of funder/provider split are crucial to how this pattern of governmental restructuring operates to define the 'market as consumer' (c.f., Boston et al. 1996; Rose, 1999: 146 ff.). Governments have become less obviously providers of services and are now seen more as 'consumers' of precisely established contracted-out welfare services. Anecdotally, Rose defines this new analytics of government as 'steering (setting policy) rather than rowing (delivering services)' (1999: 16),

Mapping the process of how individual subjectivity seeks to maintain an illusory freedom provides a new perspective from which to comment on the nature of welfare rhetoric and the discourses of dependency and risk (c.f., Leonard, 1997). This then becomes an inquiry into the nature of how such 'sovereign subjectivity' construes the welfare and social policy debate. It will investigate welfare subjectivity not on the basis of some preordained analytic of reason but as examples of specific and patterned discourses. It will reveal how that critique 'ethically reconstructs welfare recipients' and imputes aspects of moral choice to their dependency. This contemporary 'analytics of government' represents the redrafting of former state welfare responsibilities from services provided by virtue of citizenship entitlement to those delivered by contract through public or private providers.

Any effective challenge to these welfare idioms will have to reveal both the explicit and implicit forms of those welfare policy rationalizations that define those in need of aged care or unemployment 'benefits' as 'consumers' and not 'clients'. It will need to examine the rationalizations that have reframed the patterns of welfare governance whereby 
governments are no longer direct providers of services. It will have to challenge the pejorative 'frame' of anti-dependency rhetoric that increasingly surrounds the provision of support to solo-mothers and demonstrate that it is a reflexive discourse. It will have to reveal the 'social' costs of exclusion, particularly in respect of indigenous minorities, and challenge the new 'regimes of control' that rewards 'winners' and punishes 'losers'. It will need to demonstrate how such a negative construction of a necessary obverse for all welfare claimants increases the problems of risk society. It will need to 'ask the price that modern freedom exacts from those who lack the resources to practise it' (Rose, 1999: 97).

The argument that poverty and dependency are not subjective 'qualities' of the person but also involve issues of structural 'status' must be revisited. And we will need to resile from depending on rhetoric that is explicitly normative or universalizing and accept that social justice now requires debating the processes of subjectification at a host of specific and explicitly non-generalizable 'sites'. We can, therefore, use Foucault's ideas to 'reshape and expand the terms of the political debate, enabling different questions to be asked, enlarging the space of legitimate contestation, modifying the relation of the different participants to the truths in the name of which they govern or are governed' (Rose, 1999: 277). This agonistic function and how we apply Foucault's ideas to social policy may be his clearest legacy in that it does provide a way to 'talk truth to power' by arguing that all policies must, by definition, be open to dispute and reappraisal. We can thus 'map the roles and operations exhausted by 'different' discoursing subjects' and plot where they may intersect in their struggle for 'interpretive dominance'.

All of this, if it is possible, requires the fashioning of a new social policy 'tool box', the elements of a genealogy of 'welfare', that looks at poverty and disadvantage from within Foucault's governmentality 'lens' - the 'microphysics' and not just the 'macrophysics' of power (c.f., Procacci, 1989, 1991, 1994). His analysis of 'limit-experience' provides a way to critique the hidden norms of our present politics that assumes that there can be 'no alternative' to the policies that now hold sway. In that sense, his call to analyze the forms of rationalization and never to be 'comfortable' with any one aspect of reasoned assurance is not to posit a constant insecurity, as such, but to have us persistently 'do the work of freedom'. As Rose has argued: 
In showing us that what we take to be solid and inevitable is less than we believe, genealogies of power and freedom also show us that we do not know what human beings are capable of, and that it has been, and is, possible for even the most unlikely of subjects, in the most unpropitious circumstances, to act upon their limits in the name of no principle but that of their own life. Above all, such analyses seek to open, but not to close, the space within which human beings, being the kind of creatures they have become, can exercise their political responsibilities. (1999: 284)

Foucault's arguments about 'limit-experience' have shown us that even the most intransigent and powerful processes of government can be considered less 'solid and inevitable' and that in fashioning responses to this we, as subjects of government from the social point of view, can 'act upon our limits' (c.f., Procacci, 1989). Rose's idea, that even the most 'unlikely' can act 'in the most unpropitious of circumstances' to 'exercise their political responsibilities' is arguably the strongest collective sentiment that we derive from the rhetoric of social democracy. It is a humanistic expression of possibility and 'hope' that Foucault would not have allowed himself, but it is one to which aspects of his work can be applied. Nonetheless, it would be facile to present Foucault as a 'Masked Humanist' and to declare that 'underneath' all of his expressed anti-humanism he was really still 'one of us' - a progressive lying in waiting perhaps!

What he does provide is a way to examine critically the rationalizations that shape welfare politics. However, what we do with this 'knowledge' can never be assumed to follow some imputed or undisclosed Foucaultian intention. He was quite clear about his pessimistic view that people can act in respect of individual rights but that such actions cannot be seen to 'create a new way of life'. He argued that 'we live in a legal, social, and institutional world where the only relations possible are extremely few, extremely simplified, and extremely poor' (1997c: 158). Obviously, we cannot now generalize from these particular expressions of human agency, no matter how laudable, to establish some new vision of human betterment (c.f., Bernstein, 1995). The implication of this for social policy is that we can take up Foucault's critique about 'limit-experiences' but not necessarily accept that the kind of disciplinary controls that he outlined, which led to his relative pessimism, remain as all-encompassing as he argued.

His reluctance to 'thematize' the ethical-political perspectives that arise from his critique has posed difficulties for those of us who would apply his ideas to craft a new critical orientation within social policy. As Bernstein argues:

At best, we have only hints and suggestions, not all of which seem compatible. And, at times, Foucault seeks to deny us the conceptual resources for dealing with the very 
issues his analyses force us to confront. This is one reason why his critics find him confused, contradictory, and incoherent. Foucault's own inciting rhetoric of disruption forces us to raise questions and at the same time appears to deny us any means for effectively dealing with these questions. (1994: 234)

However we apply his ideas they cannot be explicitly used to comment on these new regimes of control that Rose described. How we shape the future will be our responsibility but it can be given that 'lift', that 'hope' if we apply Foucault's ideas to critique the rationalizations that shape our social welfare politics. In that sense we may, as van Krieken suggests, revisit the idea that we may be able to move past the Foucaultian contention that we are 'merely the passive objects of power relations to being potential active 'relays' for them'.

In spite of Foucault's bleak vision, making political choices is imperatively driven by the nature of ongoing change and it is not possible to step outside of that. We are still required in our 'historical present' to seek ways to clarify and warrant 'the ethical-political perspectives that inform a critique of the present'. This demands, as van Krieken suggests, a new theory of political ethics. Where Foucault is valuable is in exposing the nature and rationalizations that frame those choices. A new form of active collective government could 'move from being an encouraged apprehension to become a reality, to capture the times, situations and extent to which we might say that government is actually 'ourselves organized for collective purposes" (1996: 213).

\section{Managing Misery and Misfortune liv}

A critical social policy, one that represents an analysis of welfare 'limit-experiences', will have to demonstrate the 'costs' that inhere in such 'mentalities of rule'. There is a contingent nature in specific 'mentalities of rule' that typify neo-liberal governance strategies (c.f., Miller and Rose, 1990). This will allow for an estimate of the 'costs', associated with these specific rules of governance, to be ascertained without recourse to the former normative defences of the 'social', typical of previous social policy research (Burchell, 1993: 279). The real issues of market exchange are not simply about the necessity to manage the possibility of risk.

These questions, Foucault argued, were not just technical ones - involving aspects of programmatic failure. It is not simply a matter of trying to redesign more effective social policies but to inquire into the purposes and functions of how the analytical rules and 
rationalities that govern assessments about what constitutes effective social policies are formed and maintained, especially how it construes current definitions of citizenship. An effective critical social policy will require new tools of criticism that are not forged out of the old normative shibboleths where the idea of the 'social' was an unquestioned 'reality'. Such critical social policy would focus, as Hewitt argued:

... on unearthing such knowledge, e.g. the hidden histories of struggle or the disqualified accounts of low ranking personnel, local criticism emerges as part of a wider and more dispersed offensive waged against various centres of power - the hospital, the asylum, the prison, the welfare organization. These provide a basis for histories that throw light on present systems of discipline and knowledge; genealogies that promote tactical interventions. (1983: 77)

Despite endless debates about social justice such talk is often voided by the use of particular forms of political theorizing that are fundamentally ironic while couched as if they are simply common sense reflections on the imperatives of the market. They are expressed, as Baudrillard suggests, in symbols that only reflect individual 'contingency' and reject any legitimacy for those who are dependent (1993: 160). These symbol systems define need not as legitimate requirement, or as an acceptable aspect of the life cycle, but demand? Despite various attempts by critical theorists (c.f., Fraser, 1996) to 'demystify the current common sense about dependency', it is clear that such arguments have little public sway. The genealogical project that Fraser is committed to in respect of dependency is important, but if it resorts only to an ideological analysis of power, expressed polemically, then it is weakened.

Social policy requires a more subtle understanding of why it was that Foucault eschewed polemics. Couching the transforming or revolutionary claims of a welfare class within normative symbol systems does not deal with the fact that modernity has hidden the old working class debates. He contended that respect for difference is 'something essential: a whole morality is at stake, the morality that concerns the search for truth and the relation to the other' (1984f: 381). As Honneth suggests, the wage-earning class has been easily 'diverted onto the track of private consumption'. Consequently, 'the normative potential of the working class seems to be dried up by state intervention' (1995a: 207).

What we require is not a new theory of traditional normative 'oughts' or 'shoulds' but intellectual tools to understand what 'is', in order to challenge the hegemony of common sense. And it is here that Foucault's work is most appropriate. Finding ways to 
articulate this, though difficult, may provide social policy with a more cogent ability to attack the limitations of neo-liberal welfare policy that descry differences and collapses them into the slogan - 'there is no alternative'. If we accept Baudrillard's requirement that the hegemony of the 'real' can only really be challenged at the symbolic level, then Fraser's argument that the 'facts' of need have indeed become the 'politics of need interpretation' (1987) becomes more relevant. However, as we have seen, critical theorists have a powerful resistance to this mode of speculative thinking.

Foucault might well have argued that there can be no progressive renewal, no future 'safe harbour' where we might dock the hurts of all our welfare politics with their inevitable exclusions, reversals and deceptions. But when we read him extensively it is possible to argue that we are left with his 'glimmerings of possibility' that have renewed power to awaken us to the 'hope' that Rose expressed so well. Foucault may not have wished to do that but that is not the point. In a similar vein Deleuze argued in a paper entitled 'To have done with judgement' that:

Judgement prevents the emergence of any new mode of existence. For the latter creates itself through its own forces, that is, through the forces it is able to harness, and is valid in and of itself inasmuch as it brings the new combination into existence. Herein, perhaps, lies the secret: to bring into existence and not to judge. (1997: 135)

If any 'new, emancipatory project of welfare is to be developed it must be based on a moral critique of modernity from within' (Leonard, 1997: 162). Foucault cannot easily be adduced for any radical revision of social policy. We cannot apply his thought to develop any new welfare paradigm, but we can apply his ideas 'as a function of our current situation' in that his critique of the processes of normalization expose and demonstrate the operation of various welfare discourses. His ideas about 'limit-experience' sharpen 'the jagged edges of opposition' and bring 'to the surface the underlying politics, exposing attempts to control access and appropriate knowledge' (Richardson, 1996: 290).

\section{Welfare Rationalizations and 'Limits'.}

At the end of Omnes et Singulatim he provided the clearest description of his thesis of 'limit-experience' and how it might be applied:

... those who resist or rebel against a form of power cannot merely be content to denounce violence or criticise an institution. Nor is it enough to cast the blame on reason in general. What has to be questioned is the form of rationality at stake. The criticism of power wielded over the mentally sick or mad cannot be restricted to psychiatric institutions; nor can those questioning the power to punish be content with denouncing 
prisons as total institutions. The question is: how are such relations of power rationalised? Asking it is the only way to avoid other institutions, with same objectives and the same effects, from taking their stead. (1981b: 254, my italics)

Foucault's genealogies demonstrate the nature of coercive power as it functions and do not just comment on it at the level of rhetoric. Ultimately that is the single most important question for us to ask - 'how are such relations of power rationalized'? His approach to such research was not to go looking into 'what is affirmed and valorized in a society' as if such emphases would yield the answers he sought, but rather, typical of so much of his subsequent work, he wanted to study 'what is rejected and excluded' (1998: 335).

There is a fundamental ethical intent in Foucault's ideas to expose the rationalizations of coercive power and to deny any specific set of political rationalizations the predominating rhetorical power of their presumptions. As he said, 'power is that which must be explained' (1991d: 148). For example, he set Madness and Civilization within the symbolism of a navigational journey. The promise of movement, freedom and yet the lurking or impending fear of water borne journeys establishes his linguistic metaphor about the polarity of confinement and freedom. His account of madness invites us into deeper levels of reflexive understanding. On the one hand his discussion is ostensibly about the history of madness and all its ramifications, but on the other it serves as a wider metaphor for his critique of modernity. We can, if we wish, stand apart from Madness and Civilization as we read it, but it is his intention that it ought to be read as an 'experience-book', not a 'truth-book' or a 'demonstration-book' (1991: 31-42). Foucault's 'invitation' is to take this journey with him into his history of madness in order that its insights (its alarums and scarums) might break up the 'controlling certainty' and trust we have of modernity.

Despite this wider purpose he never denies the pathetic or desperate reality of madness, the minute and hidden particulars of personal loss. He makes no effort to reduce the phenomena of madness to a set of private symptoms, draining them of any historical significance, and thus 'fitting them' for the variable fashions of psychiatric explanation.

$\mathrm{He}$ never loses sight of the intricate processes by which madness has been constructed and then variously obscured or suppressed. While he did establish a valid genealogy of madness the same is yet to be done for poverty. That work is now being undertaken but it is still in its infancy (Procacci, 1994: 207). Had he lived Foucault may well have embarked on such a quest. He said, somewhat revealingly, in response to a question 
from Paul Rabinow and Hubert Dreyfus (conducted in 1983 a year before his death) about the value of writing a genealogy of bio-power 'I have no time for that now, but it could be done. In fact I have to do it' (1997c: 256)!

Analyzing the institutions that constitute knowledge and convey facets of the "arts of government' is not, for Foucault, simply an opportunity to engage in debates about meaning - to search for reliable and trustworthy norms. He sought a vantage point from which to examine the 'taken-for-granted' aspects of modern governance. As we have seen his was no new epistemological inquiry, it was rather a search for how we construct patterns of meaning. His reluctance to determine lines of causal inquiry and satisfy Ewald's 'hope' that his writing might be progressive is best expressed in his phrase that he was pursuing 'conditions of possibility'. As he wrote:

It may be that Marx and Freud cannot satisfy our desire for understanding this enigmatic thing which we call power, which is at once visible and invisible, present and hidden, ubiquitous. Theories of government and the traditional analyses of their mechanisms certainly don't exhaust the field where power is exercised and where it functions. The question of power remains a total enigma. Who exercises power? And in what sphere? We know how with reasonable certainty who exploits others, who receives the profits, which people are involved, and we know how these funds are reinvested. But for power ... We know that it is the hands of those who govern. But, of course, the idea of the "ruling class" has never received an adequate formulation, and neither have other terms such as "to dominate," "to rule," "to govern, " etc. These notions are far too fluid and require analysis. (1977b: 213)

Foucault was increasingly preoccupied, particularly towards the end of his life, with what it means to propose an ethics of freedom. In his later work he 'put forward an ethical interrogation, an impatience for liberty, for a freedom that does not surrender to the pursuit of some messianic future but is an engagement with the numberless potential transgressions of those forces that war against our self-creation' (Bernauer and Mahon, 1994: 155). Setting out the grounds for such a task is his legacy, and consideration of it provides an opportunity to think anew about the politics of poverty and the governance of welfare. It will, nonetheless, be a task that respects the limits he placed on any prophetic or paradigmatic application of his ideas.

Whatever use we make of his ideas we cannot disavow the direction of his own selfcommentary about what he had tried to accomplish. He was not interested to subvert codes or dislocate orders of knowledge. He would not get involved in any 'revolutionary affirmation of violence' or overthrow of contemporary culture. For example, he saw his project as giving: 
... some assistance in wearing away certain self-evidences and commonplaces about madness, normality, illness, crime and punishment; to bring it about, together with many others, that certain phrases can no longer be spoken so lightly, certain acts no longer, or at least no longer so unhesitatingly performed: to contribute to changing certain things in people's ways of perceiving and doing things, to participate in this difficult displacement of forms of sensibility and thresholds of tolerance - I hardly feel capable of attempting much more than that. (1991b: 83)

There is an ethic about change and how he reluctantly affirms his contribution in the above quote that is not disingenuous. As Allen concluded, one 'reason his work resonates for us is because we are weary of the radical agenda. His achievement in political philosophy is to have contributed to the concepts we have to use to elucidate the present, even if we cannot descry in it the obscure lineaments of a future we can believe in' (1998: 195). He did not flinch from the consequences of his analyses, and he was rightly suspicious of any proposals for social betterment that had not faced the limitations of the normalizing and subjectifying rhetoric used to express that future hope. However, as I have argued throughout this thesis, there is implicit in that apparent reluctance the seeds of a very powerful challenge to the subjectifications that have shaped our perception of modernity. While he wrote little that was explicitly centered on welfare policy he did summarize his thoughts on his brief paper, Social Security (1988a) that I now consider.

\section{Social Security, Risks and Limits: Foucault's Exegesis on Welfare}

It is interesting to note how Foucault accepted that one of the 'perverse effects' of systems of social security was that they inevitably led to a 'growth in dependence'. $\mathrm{He}$ argued that the typical view of social security was that it ought to give 'each individual autonomy particularly in relation to the dangers and situations likely to lower his status or subject him'. Nevertheless, he also thought that the crucial change in welfare rhetoric arose from the linking of security with independence (1988a: 160-161). As we have seen earlier, the valorization of risk has been an important element in how the previous rhetorical under-girding of 'security' was attacked.

Hindess, describing Foucault's analysis of Bentham's Panopticon, concluded that Bentham's argument, that liberty is conceptually a 'branch of security', must be balanced with the converse - that 'liberty is a condition of security' (1997a: 262). The importance of this distinction is that it sets out the ground for Foucault's governmentality thesis that neo-liberalism established a rationality of government distinct from any 'ideology or 
normative political standpoint'. Distinguishing between liberty as a branch of security and liberty as a condition of security is not mere wordplay. The former allows for all the issues of risk to be depicted as issues of ideology or norms. For example, within this purview, welfare is contestable on the binary distinction between the 'deserving' and the 'undeserving'. " within an ideological or normative function all the excesses of moralism and judgement can appear. In Foucault's depiction of liberty, as a condition of security, we can see the elements of the argument about how intrinsic the obverse welfare 'other' is to the self-description of neo-liberalism. In this respect, the 'failure' of the welfare dependent is the obverse of the successful. As Hindess concludes, 'the freedom of members of the governed population is seen as an artefact of effective government' (1997a: 262).

The 'welfare wars' are a justification of rule - the necessary obverse of the autonomous claims of individualism. Expressed in this way the debate is not about morality but politics - the ways in which concepts of risk are used to alter how we are governed.

The notions of protection and care, which were allied with a general or social security against risk, have been destroyed. It is the shift in language that is significant - social security was reinterpreted as welfare. ${ }^{\text {lvi }}$ Using aspects of risk to associate security with independence, and not protection, is significant. That is the mechanism for the change in welfare governance. Security was dissociated from its social associations and applied to risk factors associated now with individual independence. Welfare became a pejorative term allied with dependency. As Foucault outlines, social security was initially allied with the notion of finding remedies to accidents, responding to the perversity of happenstance. The association of security with independence alters the way that risk is perceived in the 'practice of security'.

The cycle of linguistic change is complete; risk is no longer about happenstance but now encapsulates threat. It is refracted and expressed more as a 'semiology of catastrophe'. Issues of security are also linked to demands for marketization where 'economic efficiency now appears as a more important element of security, and it does so at a time where the earlier techniques of macroeconomic management are regarded as ineffective, if not indeed as counterproductive' (Hindess, 1997b: 25). The problem is that autonomy can be discussed only within the frame of threat. It is not easy to see how autonomy and independence can ever again be associated with a general system of 
social coverage. Foucault states that 'we completely lack the intellectual tools necessary to envisage in new terms the form in which we might attain what we are looking for' (1988a: 166). Nevertheless, deeper unpacking of the rhetoric about welfare change can offer us ways to challenge the stance of neo-liberal 'truth' that there can be no other alternative to the particular association of welfare with dependency.

Despite himself, Foucault suggested a way to analyse dependency that is significant. He thought that such an analysis ought to 'distinguish between two tendencies: an effect of dependency by integration and an effect of dependency by marginalization or exclusion' (1988a: 162). Prior to the neo-liberal attack on welfare states dependency was perceived to operate not between the individual and the state but rather at a personal level between people. One consequence of the promulgation of 'welfare crisis' was that beneficiaries of various social security systems might now recognize that dependency was not intrinsically personal. It could now be associated with 'an institution whose decision-making powers ... had hitherto only [been] dimly perceived'.

Consequently, a new/old variation of the 'deserving and undeserving poor' is established. It maintains the paradox of critiquing individual welfare beneficiaries while yet treating them as a 'welfare population'. The association of dependency with marginalization shows how the new focus on risk, as threat, created a 'separation between an "assured" population and an "exposed" population' (1988a: 163).

Part of the success of the former welfare state was to 'hide' its functioning, particularly aspects of access and availability, in what Foucault called a 'cloud of decisions' (1988a: 174). The system worked through an explicit set of 'silences' - things done but not talked about (c.f., Katznelson, 1986). Reliance on the 'authority' of the state was part of that 'cloud of decisions'. Now that such 'authority' has been challenged and a principle of competence and transparency adopted, making the 'hidden rules' explicit has seemingly led to a paralysis of the former sustaining metaphor of welfare. Certainly the function of this destroyed any sense of the implicit (or silent) paternalism of social security.

The withdrawal of the state from the provision of full public access to health and social services raises the spectre of the limits of state provision. This re-emphasizes the fact 
of risk and curiously increases the sense of dependency. What was part of the organic taken-for-grantedness must now be negotiated. A new contractual relationship of the individual to the state is forged out of the increased perception of limits.

\section{Welfare 'State or Welfare Society': Ethos, Institution or Project?}

The rhetorical shift in contemporary welfare policy over the past 20 years, that promulgates the benefit and utility of a 'welfare society' over a 'welfare state', represents a major discursive shift not only in policy but also in actual social provision (c.f., Powell and Hewitt, 1998). The phrase 'from a welfare state to a welfare society' encapsulates the intention of neo-liberal social theory to diminish state responsibility for the direct provision of welfare services and to contract them out to other providers. The rhetoric advocating a 'welfare society' also marks a major shift in the 'process' of welfare administration and the restructuring of agency delivery patterns (c.f., Drover and Kerans, 1993; Esping-Andersen, 1996; Fraser, 1989a, 1993; Fraser and Gordon, 1994a, 1994b; George and Taylor-Gooby, 1996; Hewitt, 1992; Leonard, 1997). While 'going to the welfare' was always fraught, scrutiny of benefit applications and entitlements to services is now more rigorously enforced (c.f., Asen, 1996; Fraser, 1989a, 1989b; Squires, 1990; Taylor-Gooby, 1987, 1993). The expectation of fraud and deceit on the part of welfare claimants is an assumed aspect of the process of benefit application.

Whatever use we may make of Foucault's ideas in social policy they cannot be cast as if they are a 'return', as a kind of normative injunctive call to rediscover something that is lost. We cannot now easily imagine how a return to the ethos of the former welfare state might be accomplished. For we have travelled too far and witnessed too great an eclipse of the old metaphors of 'social' or 'society' for any possible return - 'as though all of this [debate] was merely the 'welfare state in crisis" (1997: 226; Powell and Hewitt, 1998).

The pervasive idea of a welfare state 'crisis', whatever its substance, has changed the ethos and practices of welfare support, and with it the metaphors, normative injunctions, hopes, claims and idioms of social policy. The political transition from a 'welfare state' to a 'welfare society (is it an ethos, institution of project?) is arguably still the core question within social policy. It is one where Foucault's concept of governmentality offers new ways to think about 'old' problems of social needs, programmes and social service 
provision and how they might be politically legitimated. Political support for progressively redistributive welfare states has waned - at least this is so outside of the Nordic welfare states.

Foucault's argument that there is a structural dilemma at the core of the nation state offers one explanation why the movement away from a welfare state towards a welfare society has been so successful. He argued in his thesis about governmentality that the 'art of government' did not lie in some pre-existing natural right and that it cannot be rationalized on the basis of some super-ordinate reason. Such arguments had no effective response to the neo-liberal challenge of a welfare society apart from a defensive reliance on normative rhetoric that was increasingly nostalgic for what had been lost.

While questions about 'contradictions' and 'crisis' of the welfare state emerged in the late 60's and 70's (c.f., Pierson, 1991: $140 \mathrm{ff}$.) they represented the ideological struggle between Marxists, Neo-Marxists and the burgeoning New Right about the 'real purposes' and origins of the welfare state. Did the welfare state represent the political clout of the working class or was it an aspect of capitalist 'pacification'? These were typical of the questions that dominated social policy before the collapse of the socialist economies in Eastern Europe and also with the collapse of the socialist alternative in the capitalist economies of the West (c.f., Mishra, 1999).

One of the ironies arising from this is that 'the New Right's use of 'contradiction' is in some sense inherited from a prior Marxist position' (Pierson, 1991: 143; c.f., Culpitt, 1992). Pierson defines three meanings usually found in the application of 'crisis' in respect of welfare states; crisis as 'turning point, as 'external shock' and as 'longstanding contradiction' (1991: 144). It is the third of these meanings within social policy to which we can apply Foucault's ideas. Anticipating perhaps the emerging debates about the fiscal crisis of the welfare state in OECD reports in 1980 (c.f., Offe, 1981; Pierson, 1991) Foucault offered the following analysis:

The well-known 'welfare state problem' does not only bring the needs or the new governmental techniques of today's world to light. It must be recognised for what it is: one of the extremely numerous appearances of the tricky adjustment between political power wielded over legal subjects and pastoral power wielded over live individuals. (1981b: 235) 
Foucault set out two different approaches to this 'tricky adjustment' about welfare (Ashenden and Owen, 1999: 152-153). On the one hand there is the model of pastoral care that Foucault nicely 'caught' within the metaphor of the 'shepherd and his flock' (c.f., Dean, 1999a: chapter 4). On the other is the model of the 'city-citizen game' that encompasses the legal claim rights of citizenship. The two models fashion very different approaches to social policy-making and welfare design. The former presupposes a conception of welfare where an individual 'is to be cared for as an individual and as part of a population, as one who must be integrated within complex forms of social solidarity' (Dean, 1999a: 82). The second sets out welfare policy, and consequent entitlements, as rights pertaining to legal citizenship. It has little to do with the pastoral oversight implicit in the former.

\section{The Welfare Exchange: A Form of Gift-Giving?}

The 'welfare state problem', as Foucault conceives it, has been compounded by an ethos of social solidarity within welfare. It aimed to be as inclusive as possible of those who make up the citizen body ... [the] ideal of the welfare state thus seeks to fuse the rather different motivations of a kind of collective civic culture with a Christian love of humanity' (Dean, 1999a: 82). Another structural welfare state 'problem' is the manner and rationale for the conduct of the welfare 'exchange'. We have no readily acceptable 'forms of ethical comportment appropriate to the transfers of wealth [that such exchange] requires' (Dean, 1999a: 83; Dean and Melrose, 1999: 26 ff.). The lack of this 'ethical comportment' is exemplified in the ongoing and contentious debates about the perils of welfare dependency. These are preoccupied with the difficulties in how to provide financial support within complex capitalist societies and are often expressed pejoratively in that claimants are portrayed as somewhat morally lacking or 'knavish' (c.f., Le Grand, 1997). These difficulties raises the spectre of how best to give to those who have fallen into the minimalist safety net and who are consequently dependent.

How might it be possible to refashion a sense of welfare 'gift-giving', required in our modern democracies, that does not lead to some pejorative assumption about excessive dependency or dole bludging? Giving in an inclusive pastoral manner fashions very different welfare policies from one based on the legal claim rights of citizens. Whether this dilemma can be resolved or not the issue of a mutual relationship inherent in welfare 'gift-giving' or exchange has been relatively ignored. Approaching it from within 
Foucault's governmentality thesis provides some new insights, at the very least, into the patterns adopted for the social transfer of money within various welfare programmes. Baudrillard offers one perspective that may be useful. He defines the 'real' normative struggle between these two opposing views of welfare operating not on the 'plane of the real' but on the symbolic. He argues that the hegemony of the present system is built on its ability to retain what he calls the 'exclusivity of the gift without the counter-gift' (1993: 36). The welfare 'exchange' is only defined as a one-way exchange and we see here echoes of Osborne's earlier discussion about the so-called 'ethical labour of altruism' (1998a: 230).

The underlying epistemology of welfare transactions, based upon a citizen rights model, involved the offering of a 'welfare-gifts' (whether social service or income maintenance) associated with the refusal of any 'counter-gift'. The denial of any sense of mutuality in the welfare exchange, the rejection of any social obligatory perspective, removes the debate to the symbolic. The predominant current symbols are those that define welfare as a 'minimal safety net' or express it as 'welfare that works' (c.f., Shipley, 1991). The symbols of social obligation on those who have to give to those who have not are discredited (c.f., Culpitt, 1992).

The welfare exchange is therefore defined as a one-way transaction of dependency. It is an exchange of monetary or other support, defined as a 'social gift' that has no reciprocal correspondence. Mutual ideals of social obligation are destroyed so that there can be no 'counter-gift'. Such destruction of reciprocity, in the 'welfare exchange', is a prerequisite for reframing need as dependency. The pejorative response of neo-liberal politics requires this denial in order to sustain its critical rhetoric that welfare distribution is essentially an issue of market-based economics and can have nothing to do with any moral/ethical rhetoric of obligation or universality. The residual safety net of public assistance (the limited or minimal welfare society) is fashioned as a duty to give rather than as abligation to provide. Classically liberalism regarded all public assistance (limited or not) as an opportunity for:

... the manifestation of a feeling of compassion intrinsic to human nature and hence coeval with, if not anterior to, society and government. This purely human dimension retains its primacy even in political societies: the social duty of assistance is understood by the economists as a duty of man in society, rather than as duty of society'. (Gordon, 1991: 23) 
This powerful set of expectations that people in need ought to be an opportunity for charity by those able to give - the 'duty of man in society' - rather than any general expectation that assistance was a moral/political obligation - the 'duty of society' - is another form of rationalization.

\section{Welfare Technologies: Issues of Agency and Performance.}

The reason for this sea change in welfare politics is the continued decay in support for all manner of welfare and social policy institutions, consequent upon the neo-liberal ethos of social and political administrative restructuring. Current welfare policies contract out responsibility for social services to private and quasi-governing bodies. We can no longer presume 'upon the social bonds that ... [cemented] us into a collective totality through the agency of a unified social service animated by the ethos of the welfare state' (Dean, 1997: 224).

Contemporaneously with this relative decay in structural and institutional support for welfare organizations, two powerful governance techniques emerged that separately dictated a new post-welfarist 'regime of government'. These are 'technologies of agency, which seek to enhance and improve our capacities for participation, agreement, and action; and technologies of performance in which these capacities are made calculable and comparable so that they might be optimized' (Dean, 1997: 224, my italics). As Hindess has argued, these two 'technologies', roughly equate to the two main drivers in liberal political theory. Firstly, to 'reduce the scope of state activity' by the 'promotion of market or quasi-market relationships between and within government agencies and citizens', which limits the possible field for factional politics - the technologies of agency. And, secondly, to 'remove the provision of public services from the realm of political decision and placing them instead in a sphere of market interaction - in which ... the pursuit of private interests by many competing actors can be expected to promote the public good' -technologies of performance (1997a: 265).

Drucker had earlier set out the rationale for these themes - the saliency of agency and performance - and built them into his call to re-privatize all public sector institutions (1969). In this seminal paper he contended that all public sector institutions should be autonomous and reduced to their 'core business' activities. Drucker's thesis is closely aligned with Dean's analysis of the 'problematics' of welfare. He similarly argued that all 
social structures should have in common 'a principle of performance rather than a principle of authority'. That is that they be based on contracts between agents and not on some amorphous ideology or ideal of public service, reflecting the old ethos of welfare state governance. The previous welfare state had a certain ethical authority and normativity but lacked measurable performance criteria. His thesis about the imperatives for 'reprivatization' substantiated arguments for widespread purchase of service contracting, and targeted benefit usage, within social and health services (c.f., Culpitt, 1992).

There are, nonetheless, 'signs of hope' in that threads of resistance to this diminished valorization of the social are visible. There 'are signs that the crisis of trust [engendered by all this complex political debate about welfare state or welfare society] cannot be resolved by the very technologies of accountability that elicit it' (1997: 226). The emergence of a wide range of social protest movements (for example 'Gray Power' representing the elderly) what Rose calls 'plural affinities', will 'shape the knowledges, contest the authorities and configure the practices that will govern them in the name of their freedoms and commitments' (1996a: 353). Dean concluded that such limits and rationalizations are not immutable:

A more radical opposition is, however, perhaps possible. If the ideal of a performance society is all speed and energy, competition and calculability, 'full of sound and fury signifying nothing', then it might be our duty to re-invent the art of living that valorizes slowness, deliberation, calmness, the reflective and the meditative, subtle techniques for the painstaking and infinite task of cooperation, of the care of ourselves and others, acts of friendship and bonds of sociality, collegiality and conviviality'. (1997: 226)

What I think Foucault recognizes and responds to throughout his work is similarly reflected in the observation of de Sousa Santos that the paradigm of modernity has been exhausted through the steady disintegration of emancipation into regulation - the consequence of an elision of 'authority' into 'performance'. All the 'technologies of accountability' have compressed and flattened our ability to imagine or think about viable and alternative social futures. De Sousa Santos calls this the 'collapse of the pillar of emancipation into the pillar of regulation'. He writes that:

Such times are half blind and half visible, in that they represent a transition between that which is old and familiar, on the one hand, and what is new and strange, on the other ... The epistemological transition is more visible than the societal, and occurs between the dominant paradigm of modern science and an emergent epistemological paradigm that I call the paradigm of prudent knowledge for a decent life. (1995: ix) 
We have seen how such social 'visions' fell foul of the welfare state problem that Foucault delineated. And especially how it contributed to the very processes of rationalization that formed that problem encompassed in the paradox that the state is both an institution that reinforces individualisation yet is also a 'totalitarian principle' (Foucault, 1981b: 254). Nonetheless, social policy, as we have seen, must wrestle with a revised 'social' that is more clearly indicative of Rose's 'communities' of interest. It must also deal with the fact that the 'social' as a territory of national governments has been voided by the emergence of globalization

\section{Globalization: Social Policy and the Enduring Welfare 'Crisis'.}

In the previous chapter Foucault's thesis of governmentality was examined bearing in mind his argument that it was the 'form of rationality', rather than the ideological content of the rationalizations about the state, that determined current welfare policy. His analysis aimed to cut through the ideological 'divide' between left and right and suggested that the practice of how we govern ourselves is more important than disputes about ideological contests as such. His work has more appropriately been applied to an analysis of politics within nation states that accords with his preoccupation with modernity.

I have suggested earlier that the disciplinary motifs that dominated the first attempts of social policy theorists to apply Foucault to an analysis of welfare, while valuable, did not go far enough (c.f., Hewitt, 1983; Squires, 1990). As Osborne rather caustically observed, we can safely leave behind the 'gloomy prophet of the totally administered society' (1998b: x). How social policy might use Foucault to develop a new critical welfare perspective within the 'mutation' of the 'social' cannot rely on the analysis of welfare as a disciplinary aspect of governmentality. That welfarist paradigm has been superseded (c.f., Bernstein, 1995; Pratt, 1997). What social policy can now emphasize are the ways in which the rationalizations inherent in normalizing and subjectifying 'limitexperiences' can be developed as new and valid critique.

Consideration of these limits and paradoxes, inherent in the governance structures of modernity, provides an additional perspective about how we interpret the 'crisis' of the welfare state. Certainly the idea that the state is both an instrument of individual rationality (and a 'totalitarian principle') captures one aspect of the paradox that must be 
considered in any evaluation of the so-called 'crisis' of welfare. As a particular 'form' of discourse the precise rationality that shapes the actual practices of welfare - away from a universal welfare state and towards a targeted welfare society - has been very successful. Increasingly, however, this is not solely a debate held within separate nation states. No longer can discussion of welfare and social policy be considered intrinsic to any one nation state. More and more these concerns are framed within a nascent global social policy.

National discourses about welfare policy and practice are more and more aligned to international pressures that flow from globalized strategic patterns of development. They are forced to follow the imperatives consequent upon an economically globalized 'one world'. These supranational discursive practices are laid down by international NGO's such as the International Monetary Fund, the World Trade Organisation, the World Bank and the Organization for Economic Co-operation and Development (Mishra, 1999: 8-11; c.f., Deacon, 1997: Chapter 3). As Deacon argues, 'questions of social policy - the ways in which governments and non-governmental actors seek to shape economic and other policies so that they contribute to social objectives - are increasingly the business of supranational and global actors' (1997: 57).

While these current issues about globalization and welfare policy obviously emerged after Foucault's death, the 'disciplinary' nature of these international NGO's can be examined as an aspect of his analysis of power. For example, he was not completely unaware of the issues and he did argue that:

There exists an international citizenship which has rights and duties and which commits us to rising up against all abuses of power, whoever their author and whoever their victims ... One of the duties of international citizenship is to reveal human misery to the eyes and ears of governments, as it is not true that they are not responsible for it. Human misery must never be the silent residue of politics. It founds an absolute right to rise up and to address those who hold power. (Translated from Foucault, Face aux governements, les droits de l'homme', Dits et Ecrits Vol. 4 pp. 707-8, by Macey, 1995: 13)

While his analyses of the discourses which shape modernity - the minute detail of the practices that are represented in his genealogical researches - are focussed on the disciplinary function of reason within the nation state they can be extended to an analysis of wider control functions of globalized social policy. Even though the 'death of the social' has called an uncritical application of his disciplinary analysis (as a research imperative) into question, it may well be that his depiction of normalizing and 
welfare state (c.f., Deacon, 1997; Dean and Melrose, 1999; Mishra, 1999). Leonard has presented perhaps the most carefully nuanced understanding of this debate. $\mathrm{He}$ suggests that class based movement against such globalized 'pressures' while possible, given some of the recent stands against the policies of the WTO, remains fraught. He suggests that 'it would require a wide-ranging political movement which at the present time looks problematic in a postmodern world of diversity and identity politics' (1997: 119). Foucault's ideas can contribute to an ethical critique of welfare practice, mounted from within modernity, one that is arguably more powerful precisely because it eschews any external, paradigmatic form. Whether it is possible to construct an effective argument for a global social policy is as yet unresolved - the debate is now only enjoined.

\section{Foucault's Agonistic Citizens: Welfare Reifications and 'Limit-Experiences'}

The other area of welfare and social policy where Foucault's ideas are being applied is in relation to the burgeoning new social movements that have seized upon his ideas about agonistic transgression to further their idiosyncratic claims (c.f., McNay, 1998; Connolly, 1991). They seek to 'give voice to those who previously had no voice, those who were excluded and marginalized, and in so doing create new identities, empowered by participation in forms of resistance that produce new knowledge about political systems'. They 'are an important element of identity formation within social movements concerned with welfare' (Leonard, 1997: 156).

We have seen that neo-liberal welfare policies undercut the old arguments about citizenship claim rights (Saunders, 1993). "Nii Squires, for example, argues that there is a paradox at the heart of citizenship theorizing because the evolution of citizenship criteria went hand-in-hand with strict eligibility criteria for limiting rights (1990: 142). Cooke suggests that neo-liberal welfare policy explicitly limits 'the recognition of - and indeed, toleration of - difference' (Cooke, 1997: 280). Honneth argues that 'motives for rebellion, protest and resistance have generally been transformed into categories of "interest" (1995b: 161). The former expressive feelings of 'indignation' are not accorded the same validity. They cannot easily be reified into anything other than what they are.

Rebellious protest and resistance can, however, be transformed into rational arguments for bureaucratic deregulation and the supremacy of contract as a governance 
mechanism. Indignation at lack of recognition is thus redefined as 'competition for scarce goods' rather than being 'a struggle over the intersubjective conditions for personal integrity'. The implication for this in denying legitimacy to welfare claimants is obvious, since 'the moral grammar of social struggles has to remain hidden' (Honneth, 1995b: 165).

These new social movements developed out of the 'collapse of the organizing metanarrative of the class struggle' and the decay of the forms of modernity, expressed in the ethos of welfare states. The forms of rationalization that governed the previous ethos of welfare had an institutional 'plan' for all and claims to be operating in the interests of all. It was the consequence of an organized social movement that epitomised the rhetoric of social solidarity. The welfare state was expressed, as Leonard argued:

... in a social movement which was founded on a particular set of identities, cultural assumptions and shared historical experiences, namely, the labour and trade union movement and the various socialist, social democratic and communist parties associated with it. (1997: 153)

Foucault's thoughts about the possibilities of freedom led him to put forward the idea that we can avoid the political binary blackmail of being 'either for or against'. His concept of 'limit-experience' suggests the possibility of a transgression of these limits that he called 'agonic'. Deleuze pointed out that through his ideas of agonistic 'refusal' Foucault had found a way to resist the ubiquity of power that had earlier drawn him into some irresolvable dilemmas:

Rather than speaking of an essential freedom, it would be better to speak of an "agonism" - of a relationship which is at the same time reciprocal incitation and struggle; less of a face-to-face confrontation which paralyzes both sides than a permanent provocation. (Foucault, 1983: 222)

It is a tantalizing thought that somewhere, somehow we might be able to use Foucault's ideas to mount a renewed defence of the politics of difference. That somehow, when he talks of 'transgression' or 'provocation' or 'struggle', he is laying out the intellectual ground for a revived progressive politics. However, he cannot simply be adduced as a 'champion' of the politics of identity focused on any particular social movement. $\mathrm{He}$ contended, within the framework of his ideas about 'limit-experience', that simple opposition or rebellion was ineffective. He thought that the 'ethical problem of the definition of practices of freedom ... [was] more important than the rather repetitive affirmation that sexuality or desire must be liberated' (1997c: 283). He challenged the 
forms of rationalization that shaped the limits of modernity. The rest is up to us and what choices we take cannot be explicitly Foucaultian!

To go past the limits of this explicit statement about how his ideas might be applied abandons Foucault or turns him into someone that he was not. He did not look for alternatives because he argued that we 'can't find the solution of a problem in the solution of another problem raised at another moment by other people. You see, what I want to do is not the history of solutions' (1997c: 256). He said elsewhere, which provides another perspective on his disdain for progressive politics per se, that the historical ontology of ourselves must turn away from all projects that claim to be global and radical'. He thought that attempts to escape from 'systems of contemporary reality' only led to their replication and that what might come next could lead to 'the return of the most dangerous traditions' (1984a: 46). He thus poses some awkward questions to those social commentators who apply his ideas too uncritically and try to bend them too unreflectively to their own theoretical tasks (c.f., McNay, 1998). As Dean contends:

We should be concerned, then, not so much about the recuperation of his work for philosophy, history or the social sciences, than with undertaking a form of analysis concerned with the limits and possibilities of how we have come to think about who we are, what we do, and the present in which we find ourselves. We can use Foucault to form or reform ourselves as philosophers, historians and sociologists, but we can also use Foucault to inaugurate a critical engagement with our present, with its limits and its practical potential. (1995b: 18)

What Foucault's patterns of investigations made more possible is that ethical behaviour be understood discursively and as an integral part of a system or patterning of ideas. His agonistic purpose was to argue against making such distinctions between ethics and morality - to set out the detailed nature of such 'moral regulation'. This is set against a background assumption that all our behaviour needs to be evaluated on the basis of how it reflects the functioning of power. One way to 'understand' what Foucault meant by the ubiquity of power, and its elusive nature, is to reflect on his question to Paul Veyne 'how is it that there is so little truth in truth' (Veyne, 1993: 8).

What he meant by this is not really too elliptical. The phrase 'in truth' refers to the notion of an incontrovertible Truth of Reason - the explicit ethos of the Enlightenment. That there may be 'so little truth in truth' is still an imaginative rallying point for critical theory. It calls common sense assumptions into question and suggests a method to challenge current political hegemonies. Descombes commented that Foucault sought to 
address 'the issue of the morality which characterizes our time - the morality of autonomy'. He argued that autonomy 'means that our conduct cannot be governed by motives of the common good of the group or of a sacred law' (1987: 20). This is so important in challenging those rationales for the rejection of the welfare 'other'.

Foucault not only questioned the legitimacy of the rationalizations for individual autonomy but also rejected 'the assumption that domination falsifies the essence of human subjectivity'. Equally, he wanted to stand apart from the universalizing claims of humanism - to avoid the potential tyranny of 'ascribing to them the teleology of progress' (Gordon, 1980: 239). Our 'subjectivity' is not often essential to anyone else but our selves (and our immediate intimates) and cannot really be used to 'name' the world. Similarly, our drive to find a universal ethical touchstone for our coveted social 'utopias' cannot easily be generalized into dependable political forms.

We may not easily argue for any notion of social obligation in respect of our welfare policies but we can apply Foucault's agonistic imperatives to continually confront the discursive limits that we take for granted. This will be an opportunity to think more clearly about the 'limits' and 'possibilities' of welfare practices and various social policy discourses in order effectively to 'inaugurate a critical engagement with our present'. As Rose has argued:

Some ways of governing are intolerable precisely because they exclude the possibility at least for some who are subject to them - that their life should become its own telos, that they should be able to practise an active art of living. We may not share an essence, a soul, an identity or any other fixed attributes with others. But there is one status that we do share, and that is our status as subjects of government ... we are inhabitants of regimes that act upon our own conduct in the proclaimed interest of our individual and collective well-being. To the extent that we are governed in our own name, we have a right to contest the evils that are done to us in the name of government, a right we acquire from our birth and life at the point of convergence of practices of government themselves. (1999: 284)

While these issues are vigorously contested at a philosophical level there is, nevertheless, some empirical evidence (c.f., Jayasuriya, 1996; Meredyth, 1997; Saunders, 1993; Taylor-Gooby, 1993) that despite its current dominance neo-liberal social theory has not entirely dismissed the relevance of citizenship theorizing. Despite major retrenchments in the levels of benefits and access to services, and the depiction of the revamped welfare systems as representative of a welfare society and not a welfare state, the basic structures of income maintenance and support remain. 
Given this there is still the possibility of resistance to welfare cutbacks that demonstrate what Tully refers to as the 'agonic freedom' of citizens (Tully, 1999a; Mouffe, 1992, 1995).

This is not to argue that the communitarians have surreptitiously won. Rather it is to point to very interesting work done by Saunders who, accepting that the socialist mode of citizenship has indeed withered, nevertheless makes an argument for the emergence of a 'privatized mode' of citizenship. His contention is that the growth of the prevailing privatized nature of consumption 'enhances rather than diminishes citizenship' (1993: 62). His thesis is a significant one. The empirical evidence, he adduces, does suggest some possibility of a bending back, if not a convergence, in the classical stand off between the one and the many. ${ }^{\text {Iii }}$ As he says:

The privatized society which is slowly emerging out of the ruins of the collectivist welfare system holds out the prospect not of social and moral disintegration, but of new and active forms of citizenship based on individual competence and the development of genuinely collective forms of association and sociability springing up from below. (1993: 88)

What is at issue is how such new models of a privatized citizenry still articulate the reason for their own privatizations on some basis of exclusion where equal political recognition is denied to groups who can be defined out of, or excluded from, the contractual consensual state. Cooke interestingly analyzes the debate within political theory about the struggle inside neo-liberalism to defend the ineluctable ideals of individual autonomy and yet assume moral responsibility for those excluded groups. There is the potential, as Cooke describes, for further structural stigmatisation. As she says, the concern is:

... whether in denying equal political recognition to certain social groups on the basis of their lack of commitment to the ideal of individual autonomy, it is desirable to distinguish further between such groups and the degree of political recognition allowable in each case. $(1997: 288)$

The possibility of a spectrum of acceptability, in relation to excluded groups, equally raises other vital questions, especially 'the (normative or pragmatic) reasons that might justify varying degrees of political recognition'. That this is not just a speculative debate will become clearer below in the discussion about whether it is correct to assume that neo-liberal politics have actually ushered in the 'death of the social' (c.f., Baudrillard, 1993; Smart, 1990). 
The overarching question, in all of the arguments about 'formal democracy', is whether it still exists in the manner in which critical theorists presume that it does. "ix It seems to me that the governmentality literature has raised serious questions about the viability of formal democracy. As the defenders of the welfare state were forced to concede, postmodernism might have also effectively undermined the justifications for those expressions of formal democracy that might sustain normative discourse.

Political discourse has become ritualised and is marketed for effect not dialogue. The arbiters of common sense have become deaf. There are no clear ways in which to compel general allegiance to an ideal of normative social progress. Certainly not if that means privileging such social aims over the power of the new self-referent 'communities', and particularly not if critical theory harks back to an 'unsupportable objective teleology of history' (White, 1988a: 153).

\section{Foucault's Quizzical Ethics.}

Foucault proposed no 'once-and-for-all break with a universal and total form of reason'. What he offered was a form of ethical reflection, 'an 'experimental' attitude that crosses and recrosses the limits of our form of rationality' (Dean, 1994a: 54). What he meant by freedom and change could not be expressed within any paradigmatic revolutionary rhetoric. Foucault was 'always focusing on instabilities, points of resistance, specific points where revolt and counter discourse are possible' (Bernstein, 1995: 234). $\mathrm{He}$ argues for an insight that arises out of an intellectual implosion of ideas not some new explosive transforming synthesis. He sought new possibilities 'arising from the work of criticism, an option emerging through trenchant historical and theoretical work'.

It was, therefore 'a form of critique which uses the knowledge of limits to establish political options without prescribing resolutions' (Dean, 1994a: 54). It involved the patient detailing of 'limit-experiences', unraveling the form of the rationalizations that constitute the present practice of politics within modernity. Consequently, the nature of such research was 'experimental, marking a zigzag path at the limits under which the present is constituted for various modalities of contemporary experience' (Dean, 1994a: 55). 
Osborne's summary of the influence of Foucault on contemporary social theory, that it was quizzical yet ethical, captures perfectly the sense that so many of his critics had who stumbled over his significance. He remained an intellectual irritant in that what he argued 'felt' clear even when not able to be expressed clearly. Osborne's view that he was a teacher 'striving for a reimagination' of himself through a particular critique of enlightenment reason 'gets it right'. Even though Foucault personally dismissed such an ascription to his role (1991d: 34). Foucault's importance to social policy lies in this constantly agonistic stance towards those perceived social truths that have become immutable and frozen. His ethical, 'quizzical' challenge was to set out ways that we might breach these limitations. But it always came 'shrouded' in the paradoxical. For example, he said of modernity that the 'high value of the present is indissociable from a desperate eagerness to reimagine it, to imagine it otherwise than it is, and to transform it by not destroying it but by grasping it in what it is' (1984a: 41).

The enduring question for social policy is how to make use of these arguments. Clearly sociologists, like Osborne, have contended that Foucault while obviously 'oriented to social issues' was not a sociologist. Agreed - but this was never a claim that Foucault made for himself! The dilemma for social policy theory is that its conceptual focus is centred on society, on the structures of how societies operate in their welfare arrangements and it is evidentially grounded, in part, within sociological arguments. Osborne is right when he argues, 'what would be unquestioningly absurd would be any attempt to appropriate Foucault straightforwardly and unproblematically to the project of sociology' (1998b: 127).

The same is true for social policy. However, while dismissing him from the sociologists 'camp' Osborne yet declares that Foucault's work has 'an ethical character', serving a 'quizzical rather than a nomological' function, and thus serves as a valuable pointer towards what 'social theory can look like' (1998b: 126). Foucault was adamantly opposed to any nomological approach to argument. Setting out the 'law' of discourse, or proposing a new synthesis was clearly anathema to him. So the dilemma for social policy is that the basic epistemological structures of social theory cannot easily encompass him but yet are still entranced by the 'promise' - the agonistic 'possibility' inherent in the quizzical and radical nature of his ideas. It is in threading our way through this dilemma that Foucault's ethical challenge retains its significance. 


\section{Conclusion}

If we are to reconsider our social welfare policies anew and to treat them as a series of 'limited enterprises' then we must follow Foucault's argument that we should know what they are, where they come from and on what particular sets of rationalizations they stand. He suggests that what we then discover is 'neither a configuration, nor a form, but a group of rules that are immanent in a practice, and define it in its specificity' (1972: 46). How certain sets of ideas emerge and are enshrined in a discipline is a liberating notion. The point is that as a discipline they are, as Foucault argued, to be regarded as being 'in a constant state of renewal, subject to constant discoveries, criticisms and corrected errors' (1972: 47).

Similarly, to ask how does welfare mean is a more productive question than to ask what does welfare mean. The same principle can be applied to poverty, dependency, social success, unemployment, social policy analysis etc. What are the 'enigmatic treasures' of neo-liberal social and welfare policy that shaped the discourse of common sense? Asking such questions, arguably, provides new tools to query the 'tired' discourses of left and right. How was the 'battle' formed and enjoined may be of more use than what was its history. If we define these debates as strategies (left and right; Omnes et Singulatim) in the Foucaultian sense then the problem, as he said was 'to discover how they are distributed in history' (1972: 64). What is the 'necessity that links them together' and how does that become 'invisible' within the coded literatures of the discipline? These are the ongoing questions to which Foucault sought answers all his life.

As social theorists we, at least, need to consider whether dismissing such questions as irrelevant to our social policy debates does not confirm the veracity of his observations about their practices. It may be that we must, in time, reject Foucault's methodological investigations not because they are false but because they may be too hard to do. As he said, to accomplish this requires us to to describe each time the rules for the formation of objects, modalities of statement, concepts and theoretical choices' (1972: 64-65).

Perhaps we do need coded formulations in order to say or think we know anything? Nonetheless, embarking on such an investigation into social policy has value whether or 
not the destination (as set out by Foucault) is achievable. He did, however, know how to do this with respect to Madness and Civilization. He thought that:

... the difficult point of the analysis, and the one that demanded the greatest attention, was not the same in each case. In Madness and Civilization, I was dealing with a discursive formation whose theoretical points of choice were fairly easy to locate, whose conceptual systems were relatively uncomplex and few in number, and whose enuciative rules were fairly homogeneous and repetitive; on the other hand, the problem lay in the emergence of a whole group of highly complex, interwoven objects; it was necessary above all to describe the formation of these objects, in order to locate in its specificity the whole of psychiatric discourse ... but I did little more than locate them, and my analysis scarcely touched on their formation. (1972: 65)

For social policy the vital question of Foucault's importance is whether we can ever interpret the social discourses of welfare - dependency, and 'dole bludging' - as if the answer to these issues lay in finding a 'history of the referent'. That is to explain by detailed and careful explication the cultural totality of all that had gone before. Such investigations have led social policy theorists into a cul-de-sac where the proper and only rational response to disadvantages, dislocations, social despair and exclusion was some species of normative injunction. That has been a seductive labyrinth that has conspicuously failed to 'lever' the politics of the present. If social policy only worked and had a cachet because it had 'defenders at court', and now so obviously does not, surely it is these questions that might more properly and profitably exercize our minds? As he says, his 'point is not that everything is bad, but that everything is dangerous, which is not exactly the same as bad. If everything is dangerous, then we always have something to do (1984d: 343 ). 


\title{
Chapter Eight
}

\section{Foucault's 'coldest of all cold monsters'!}

\begin{abstract}
I do not think that a society can exist without power relations, if by that one means the strategies by which individuals try to direct and control the conduct of others. The problem, then, is not to try to dissolve them in the utopia of completely transparent communication but to acquire the rules of law, the management of techniques, and so the morality, the ethos, the practice of the self, that will allow us to play those games of power with as little domination as possible. (Foucault, 1997c: 298)
\end{abstract}

Now we all live, comparatively speaking, in far too great security for us ever to acquire a sound knowledge of man ... As long as truths do not cut into our flesh with knives, we retain a secret contempt for them: they still appear to us too much like 'winged dreams', as though we were free to have them or not have them. (Nietzsche, 1997: 192)

For Foucault the 'coldest of all cold monsters' was of course the state! Like Nietzsche (from whom he borrowed the phrase) ${ }^{1 x}$ he might well have seen risk (and the need for security) as fashioning a politic that made 'sound knowledge' of each other impossible. For example, he found the antinomy of 'large destructive mechanisms' and institutions oriented toward the care of individuals', co-existing in politics, genuinely puzzling and needing investigation (1988b: 147). His aim in examining a wide range of political rationalizations, applying his analysis of 'limit-experiences', was 'never ... to analyze anything whatsoever from the point of view of politics, but always to ask politics what it had to say about the problems with which it was confronted' (1984f: 385). He revealed the forms of rationalization that create such disciplinary controls. While he did not assume that it was possible to 'defeat' the disciplinary society, he did set out an approach to the critical examination of 'limit-experiences' that that he thought might 'allow us to play those games of power with as little domination as possible'.

This apparently simple ethic of refusing to debate at a polemical level and to concentrate instead on the practices of power and the rationalizations of subjectifying limits is woven throughout his work. It is the most revealing of his elusive stances. That this statement comes from one of the personal discussions and commentaries that he made in the months before his death grants it an especial significance. It represented his life-long 'tangle of problems' to understand the 'forms of rationalization' that construe our knowledge of 'truth'. Indeed, shortly before his death he was working on a plan for a 
new series of books with Paul Veyne that was to be a history of the 'production of truth'. This would have examined the 'relation between truth, self-constitution and problemization ... enabling him to avow in a volume published just before his death that his abiding interest was a "history of truth"' (Flynn, 1991: 177). His intent in this series was to move past the 'frozen rhetoric' of rigid polemics (such as the neo-liberal certainties that there can be 'no alternatives') to find and expose the hidden linkages in such discourses and to refine his analysis of 'limit-experiences'. That search for truth, which for Foucault required embracing certain 'discontinuities' and contradictions, is an ethical challenge of real substance to the rigidities of our current social and political rhetorics.

His depiction of how we might 'think differently' about the multitude of practices involved in welfare discourses provides an opportunity 'to know ourselves in a certain way' and to reflect on how 'we seek to direct our conduct and that of others' (Dean, 1998: 196). I have argued that this is his most important legacy, not only of course in respect of welfare and social policy discourses but also in how we shape our general politics. The dominance of those systems of welfare analysis that would deny the 'otherness of need in each other' is transparent. How that set of intellectual practices came to be, and how it directs our conduct, raises issues for which we must constantly search for answers even if we may never resolve the discursive requirements imbedded in antiwelfare discourse.

These are questions for which Foucault's work provides not answers but exemplary method. As Dean argues:

There is always another side to what is constructed in these 'regimes of practices'. We deal with 'suffering' in particular forms of discourse and have particular ways of 'treating' it, and these regimes of practice and truth may augment or diminish, or transform in some other way, that suffering, but they are never its totality, and they never construct it. The ethical responsibility that falls to us is to analyse the limits of the necessity of these 'regimes of practice' and the possibilities of their transformation within what Foucault called the 'rights of the governed' and towards creating a clearing for the undefined work of freedom. (1998: 196)

Despite the radical disjuncture that his ideas present Foucault was committed to finding a new basis for real discourse within an acknowledged contingency of all debate (c.f., Allen, 1998; Bernstein, 1995; Tully, 1999a, 1999b). He argued that the typical discourses of polemical politics are 'parasitic figure[s] on discussion and an obstacle to the search for truth' (1984f: 382). He explicitly rejected the possibility of a normative 
stance, let alone the possibility of explicating policy on the basis of such assumptions! He did not, however, reject the valid search for some 'understanding of what a modern ethic would look like' (Nielsen, 1997: 9). Espousing a critical position requires the adoption of a stance, an attitude, rather than seeking to complete an analysis that could be normative (c.f., Valero-Silva, 1996).

The question for social policy is whether we can find a position for critical theory that can elucidate the whole, and to see what aspects of the normativeness of its former inclusive stance should be respected. In searching for such an ethic, social policy must articulate how the 'sovereignty' of contemporary common sense politics can be challenged. Ironically it is Foucault who has, in his theory of 'limit-experience' sketched out the clearest perspective on how this might be achieved.

Diverse practices of governance, developed out of the political protection of a radical 'self-politicization', are reflexive. Different antinomies of control and care do co-exist. The 'welfare - other', subject to the disciplinary politics of the state, is the obverse, not the separate object of that 'self-politicization'. The character degradation that now typifies so much of the argument to re-impose a moral revaluation of the welfare recipient as an active consumer is a particular refraction of 'limit-experience'.

Suggesting that we listen to the 'truths' of those who must survive as welfare beneficiaries may seem hopelessly romantic: the 'winged dreams' of Nietzsche that are so apparently evanescent. Yet the moral vision that welfare policy might express the desire for a more civil (and nurturing society) need not be abandoned. Understanding that our divisive politics are founded on complex reifications of risk - both to defend the project of self-politicization, as well as reject the legitimacy of 'social' need - allows us to recognize the political legitimacy of that obverse. It would require, as Foucault argued, that the 'discourse of subjectivity ... be cut loose from its moorings in bourgeois individualism' (Richters, 1988: 632). Allowing for a thorough examination of the politics of security and risk, especially how this has created our deep social divisions, might yet let us 'acquire a sound knowledge of' each other. 


\section{Control Redux!}

The nature of these welfare practices faces further problems that Foucault could never have foreseen. I have previously discussed Rose (1999) and Deleuze's comments on how Foucault's depiction of a carceral society represented a codification of certain subjectifications that were superseded by a 'regime of control'. Deleuze defined this as a transformation from analogical systems of control (those 'sites of confinement prisons, hospitals, factories, schools and the family' (1995: 178) to digital societies where regimes of control were based upon communicative codes (passwords) and constant feedback. He argued that the controls are no longer based upon systems of 'molding' or shaping but on modulation - 'a self-transmuting molding continually changing from one moment to another' (1995: 179). Thus governance is now more properly seen to be about potentiality, the active roles of consumer and participation, and is less driven by the precept that determined static analogical controls, typical of the 'carceral archipelago'. The question is no longer the governing of Foucault's 'docile bodies' but how we are to be governed through these codes. Deleuze's insight is that the old sociological determinants of mass/individual have now been transmuted into the new 'information' required by 'samples, data, markets, or "banks"'. 'Disciplinary man', he argued, 'produced energy in discrete amounts, while control man undulates, moving among a continuous range of different orbits' (1995: 180).

Foucault did apply his notion of 'bio-politics' to understand and critique the complex patterns and practices of such systems of governance. But in some essential sense this analysis always takes us back to what Deleuze referred to as the 'skin' of subjectification with the implication that in some way such 'limit-experiences' ended at the skin of the self (1995: 87). Nikolas Rose, in a recent unpublished paper, has speculated on the vast social implications consequent upon the mapping of the human genome. $\mathrm{He}$ argued that the new possibilities of 'control' arising from the appropriation of this knowledge are epochal. They penetrate 'beneath the skin' and will impact on our present 'regimes of control' in ways we can only dimly discern. Foucaultian bio-politics in this analysis merges with what Rose has called 'ethopolitics' - the politics of life itself and how it should be lived'. As he stated:

In ethopolitics, life itself, as it is lived in everyday manifestations, is the object of adjudication. If discipline individualises and normalises, and bio-power collectivises and socialises, ethopolitics concerns itself with the self-techniques by which human beings should judge themselves and act upon themselves to make themselves better than they are. (2000: 17) 
Metaphors of understanding and control will need to change, for governing the 'ethopolitical welfare body' will apply other ideas than those drawn from our present political and social paradigms. New imperatives will be laid on welfare clients to compel them to take up these new 'ethopolitical' responsibilities. New ways will be found to 'govern the newly inscribed dangerous' (c.f., Pratt, 1997). These will be shaped by what answers we can fashion in response to the following questions.

- How will new forms of 'social' analyses flow from this newly emerging governmentality of the bio-politics of life?

- How will welfare need and dependency be inscribed within the new forms of governmentality that knowledge of the human genome provides?

- What will be the consequences of the incipient regimes of control that can winnow populations on this basis?

- Who will have access to these codes and who denied access?

- How will these questions shape the future political community and the politics of knowledge, access and control demanded of those with access to this information?

These new governmentalities will not end at the 'skin' but will penetrate the defensive bodily self-awareness and alter the internal 'No' that Foucault thought so essential to agonistic 'refusal'. What will 'governing through freedom' then mean if new and more intrusively powerful rationalities emerge out of the ability to 'govern life itself'?

\section{Risk and Social Policies: What is to be done?}

Foucault made the observation that 'whereas the end of sovereignty is internal to itself and possesses its own ... laws, the finality of government resides in the things it manages and in the pursuit of ... tactics' (1979: 13). The depiction of the 'arts' of government as tactics rather than laws might seem odd, given the legislative and mandating power of the state. However, distinguishing between law and tactics is important. It opens up the possibility of challenge and counter-tactic. For example, if neo-liberal rhetorics of common sense can be defined as tactical, rather than laws of governance, then dissent can more easily be lodged against their 'truth-claims' and its practices made clear. The polemic of common sense within neo-liberal social policy reified risks, their definition, their locales and their resolution into the tight logic of specific policy. It is possible, as a counter-tactic, to raise such reifications for scrutiny. Another, obviously more difficult task, is to argue that such reifications are in fact immanent discourses, which neglect the social 'realities' of the 'welfare - other'. 
We could perhaps retreat into the security of Foucault's canard, that academic discourse ought not to be a vehicle for practical injunction 'love this; hate that; do this; refuse that' (Gordon, 1991: 6). However, as Foucault observed:

... there is a parcel of thought in even the crassest and most obtuse parts of social reality, which is why criticism can be a real power for change, depriving some practices of their self-evidence, extending the bounds of the thinkable to permit the invention of others. (Burchell, G. Gordon, C and Miller, P, 1991: x)

In the end, the continuing viability of neo-liberal welfare policy will depend on whether individual autonomy and security can be linked together in the development of policies that are mutually enhancing. To suggest this is not illusory contradiction. It is rather an invitation to both aspects of that policy continuum to submit their 'practices', their 'arts' of government, to mutual scrutiny. One vehicle for this is a thorough analysis of risk and how the palimpsests of each can be merged and rewritten. ${ }^{\mid x i}$ There are two transparent and interlocking palimpsests of risk ('mental parchments') that reflect attempts to create autonomous perspectives and understandings, where risks are again made manageable and solutions accessible. One is personal, shaped by our private assessments of potential danger. The other, a public inscription of the massive fears reflected in risk society, could be neither managed nor made easily accessible. These palimpsests are flung over each other, almost at random, as we try (like former shamans examining the entrails of the sacrificed) to discern from their random conjunction the shape of what is, or might be.

The enormous logic of change, unleashed by neo-liberal 'mentalities of rule' is rational and premised on a valorization of common sense. However, there is another aspect to how such particular 'mentalities of rule', the 'practices' of governance, can be challenged. They have reified the logic of common sense into a set of explicit norms. However, hidden in these norms is a longing for transcendence - a paradoxical desire to 'escape' the contingent and risky mundane. Common sense has become part of the 'sovereignty' of neo-liberal politics. The contingent is accorded universal significance. This reflects Kant's assumption that 'the finite human being cannot avoid the illusion of the infinite (i.e. sovereign) subject precisely because it is infinite'. Foucault agrees that reifying political power 'is indeed possible on the condition that human beings are finite'. However, he also contends that 'it is precisely for this reason that one should not accept the notion of an 'infinite subject' of power' (Doxiadis, 1997: 539-540; Cousins and 
Hussain, 1984: 263). Neo-liberalism, like any other political ideology cannot lay total claim to epistemologies of common sense.

These reifications depend upon the hidden 'sovereignty of the infinite' and are illogical. They are only one more ideological throw of the contingent political and philosophical dice. This represents the simple, but powerful challenge to the awful rhetorical hegemony of neo-liberalism, which rejects the legitimacy of the 'welfare - other'. The 'sovereignty' of that rejection is unsustainable. Neo-liberal social policy demonstrates the 'despotism' intrinsic to the moral practices of governance [that is] inherent in 'the paradigmatic liberal subject's relation to himself' (Valverde, 1996: 359). Such despotism creates a crisis view of welfare support that defines welfare beneficiaries and claimants as 'abject' (c.f., Rose, 1996a, 1999). This creates the paradox: only those who can be 'saved' by their own efforts will get the help they need.

\section{The Shape of Future Welfare Discourses}

All of these new incipient controls will refashion how we can apply Foucaultian critique as commentary on these potential more insidious 'limit-experiences'. There are some constraints to how we might undertake this because they were never areas of social knowledge that Foucault considered. But his earlier work of critical reflection is not vitiated by new patterns of ethopolitical control. It is rather that some will 'play those games of control' with a renewed ability to dominate 'below the skin'. As Deleuze suggested:

It may be that older means of control, borrowed from the old sovereign societies, will come back into play, adapted as necessary. The key thing is that we're at the beginning of something new ... the widespread progressive introduction of a new system of domination. (1995: 182)

This study of Foucault's ideas in relation to risk and social policy is obviously only tentative, aimed more at generating debate than foreclosing it. The opportunity is there to do this work, or rather to continue to expand on the work already being done (c.f., Procacci, 1994; Stenson, 1998, 1999). It is important to reflect 'why so many crucial questions have been posed in such profoundly distorted ways' (Maguire, 1996: 171). The pejorativeness of anti-welfare rhetoric depends upon the structure of an argument that the 'fault' of the system lies with those who apparently misuse it. My purpose has been to sketch out the possibility that the 'fault' lies in the system itself 
(the forms of rationalizations) and that misuse is predicated by its very structure. As Wynne has commented:

$\ldots$ the powerless always tend to rationalise and thus consolidate their own impotence and apathy because to do otherwise is to expose themselves to the greater pain of explicit recognition of their own neglect and marginality. (1996: 53)

It is the cultural narratives of both side of the welfare 'divide' that are required to be set alongside each other. The neo-liberal 'logic' behind the association of security, not with the social but with individual independence, can now be seen as a necessary part of the questions which social policy can address. Focusing only on welfare dependency misses the point. The more important question is whether we can, or will, address the wider issue. Given our current focus on independent individualism, this will not be easy. The imposition of 'fault' will obviously be given very different meanings when applied to the human genome!

We have undermined the general community ethic of mutual responsibility that did inform the ethos of those who framed social democratic welfare state policies. Fragmenting 'responsibility' into a personal privatized reality has clearly generated an enormous creative energy in those now free to pursue the opportunities that a deregulated society and economy offers. The productive creativity of that cannot be gainsaid. But risks are still 'delivered', so to speak, in an obviously unequal way. The obvious inequalities of genetic, social and familial inheritance are not easily dismissed. However, our social policies are increasingly framed within discourses of equality - especially the discourses of equality associated with the rhetoric of individual responsibility and opportunity. The concept of welfare 'safety-net' is not a sufficient idea to contain the reality of the denied 'voice' of welfare discourses. Constraining the manifold differences of that 'voice' within such narrow ideas of risk, security and individual responsibility serves a much narrower and tighter purpose.

The current debates about welfare dependency and risk will only produce some 'light' if we are willing to consider the whole interactive policy system surrounding welfare. As Lowi has trenchantly concluded, the 'problem' in the present climate is that there are two apparently incompatible public policy issues: one is systemic, universal and general; the other specific, regulatory and 'piecemeal'. The welfare state involved a raft of social policies that systematically attempted to: 
... democratize the burden of bad outcomes by removing most of the blame and indemnifying as many of the victims as possible. But this half of the public policy approach to risk works precisely because the welfare state, functioning as it does through the reality and the conceptualization of insurance, works best at the level of the largest possible universe. The welfare state was, in effect, made to order for the emergent systems approach to social policy. (Lowi, 1990: 38)

The oversight, monitoring and implementation of these systemic policies are always individual and particular. The whole complex of regulations surrounding welfare 'cannot grapple with the system at all but only with specific conducts that may, cumulatively, improve the system someday, somewhere down the line'. Fundamentally, he presents the paradox 'regulation can't deal directly with risk at all. Risk is a system concept, and regulation has to concern itself with specific conduct' (Lowi, 1990: 39). This is a forceful argument, daily recorded in the problems faced by welfare bureaucracies. Examining the welfare claimant in the 'harsh winds' of a regulatory climate, which cannot individualize the welfare claimant, might well lead to a wider evaluation of the welfare state/society. Rationales for the institution of the 'old' welfare state involved aspects of a moral viewpoint, even perhaps a collective 'disgust' about the crude facts of social and economic disadvantage. Contemporary welfare systems do not express such altruistic social motivations. However, as Lowi has demonstrated, they face an almost impossible task. We require a thorough evaluation of the limits of such welfare practices.

\section{Conclusion}

These questions cannot be resolved within the scope of this thesis but they do indicate how applicable Foucault's ideas about governance are to the shape of our future politics. The impetus of the Enlightenment project was to prove that politics would ultimately be answerable to reason. But government as a 'conduct' of 'conduct' turns the rationality of government into an individual 'affair' involving all the 'irrationality' of private fears about risk. Despite Foucault's disavowal of any normative intention or prescriptive injunction, 'politics becomes, in a new sense, answerable to ethics'. Rose is surely right when he argues that 'it is likely to be on the terrain of ethics that our most important disputes will have to be fought for the foreseeable future' (1999: 188). Given the growth of his 'ethopolitical' brave new world the ineluctable may be more malleable than we think. Beck's ubiquitous risk society might make us more aware that we are 'more contingent, recent and modifiable than we think' (Gordon, 1991: 48). How we are to make possible a comprehensive recognition of difference (and recognition of similarity) will obviously preoccupy our immediate and long-term social debates. 
We do not know how to accomplish this but perhaps it must start with that acknowledgement at the very least. What we currently do to each other in our welfare discourses is repeat the mistakes of the past. We need at the very least, as Donzelot argues (1991: 178) to 'make use of our conflicts instead of trying to eliminate them' (my italics). We are in danger of institutionalizing a new/old version of 'disciplinary welfare' that is fundamentally driven by an angry uncertainty we neither acknowledge nor will admit. We need to go on articulating the values as well as the practicality of welfare. The ideological debates are crucial. But so too is the patient unravelling of the 'genealogies' of welfare policy and discourse. The 'challenge that Foucault's work makes to the word-thing-power constellation of appropriateness that makes its way into all requests for a new politics remains a deep one. It recognizes that such requests are usually a part of the search for some new morality, and an essence beneath the action of uncovering the layers of the past' (Roth, 1981: 45-46).

Only by maintaining both an ideological scrutiny and an analysis of government 'practice' can we expect to challenge the present. In Bauman's words we need to go on 'asking such questions as fear final answers more than they fear the prospect of remaining unanswered' (1997: 84). And in Foucault's words, the 'question is: how are such relations of power rationalised? Asking it is the only way to avoid other institutions, with same objectives and the same effects, from taking their stead (1981b: 254, my italics). This is not to argue for a return to the past, but to seek to expose the values that support the politics of common sense. All does need to be in question, all of the time. That is our security against wilful hegemonies that would make of the present a truth that will admit of no change. 


\section{End Notes}

\section{Chapter I: pages 1-28.}

' Gilles Deleuze read this passage at Foucault's funeral. See Eribon's description of this in his biography Michel Foucault (1991: 330).

ii Though Foucault's review of Bataille - A Preface to Transgression - offers some explanation or perhaps some justification for such extreme interpretations (1997c).

iii Perhaps the most considered commentary on Baroness Thatcher's 'intent' in this brouhaha about there being no such thing as society is Dean's in his book on governmentality (1999a: 151153). What has elevated the phrase to the status of a modern trope is how it is aligned with her comments about there being no alternative to the application of her policies.

iv The phrase 'from a welfare state to a welfare society' encapsulates the intention of neo-liberal social theory to diminish state responsibility for welfare services and to contract them out (c.f., Culpitt, 1992; Drover and Kerans, 1993; Esping-Andersen, 1996; Fraser, 1989a; George and Taylor-Gooby, 1996; Hewitt, 1992; Leonard, 1997; Mink, 1994; O'Brien and Penna, 1998a; Offe, 1996)

" Foucault's major description of what he meant by power is outlined in The History of Sexuality; Volume One (1990: 92-97).

${ }^{v i}$ See especially Boston, J. Martin, J. Pallot, J. and Walsh, P. Public Management: The New Zealand Model (1996).

vii For a complete analysis and discussion of agency theory see the above title of Boston et. al. (1996) which is the definitive depiction of the application of these ideas and reforms within New Zealand.

viii Doyal and Gough have argued that that it is still an imperative for social policy that objective needs be identified and assessed and that recognition of these is crucial in their view of what social justice requires (1991). However Leonard's perspective is one that allows social policy theorists to argue more persuasively with the rhetoric of neo-liberalism about the relativity of needs discourses. As Leonard argues:

The fact that a belief in basic human needs is culturally constructed as a discourse and practice which intervenes in a world of injustice and suffering, does not lessen its impact ... acting on the belief that all human beings have some needs in common is moral certainty enough ... exploring basic human needs cross-culturally through dialogue, provides a basis for sufficient certainty both to establish a critique of existing welfare and begin a process of struggle for the transformation of welfare. (1997: 76)

${ }^{i x}$ Honneth traces the origin of this view of politics back to Machiavelli who introduced into Florentine politics the idea that humans are 'egocentric beings with regard only for their own benefit'. Honneth also suggests that 'Machiavelli set in place a socio-ontological foundation that amounts to the assumption of a permanent state of hostile competition between subjects' (1995b: 8). 


\section{Chapter 2: pages 29-51.}

' Squires argues that social policy needs not to avoid the 'common sense'. He attacks social policy rhetoric that expresses a 'virulent form of idealism' (1990: 41).

${ }^{x i}$ Honneth's critical challenge to the denial of recognition is important. For Honneth 'the normative ideal of a just society is empirically confirmed by historical struggles for recognition' (1995b: xii). His ethical question (after Hegel) is how can we claim the morality of individual uniqueness, as a political ideal, while denying it to others?

xii It is an interesting point to note that in developing such public outcry about welfare dependency, neo-liberalism is not doing what classical stigmatization of the poor and the insane did - which was to remove the stigmatized from sight. As Douglas has suggested, in the past the 'alleviation of wrong, removing stigma could only make the privileged members of the community feel more comfortable' (1990: 15). These are no longer moral questions, if indeed they ever were! They are political, about power and governance issues. The current stigmatizing of welfare, in a climate of Beck's (1992) risk society, is essential to the heart of neo-liberal assertions of the individualized self.

xiii White indicates why Habermas had such trouble in accommodating the notion of a 'prerational, embodied otherness'. The maintenance of a 'rational, self-reflective, self-mastering subject of the humanist tradition' was essential to Habermas' defence of normative argument (1988a: 145).

xiv Wain, defending Foucault, suggests that Foucault's argument 'is not to be regarded as Cartesian self-absorption but as a kind of activity on and within the world' (1996: 359, my italics).

${ }^{x}$ This may not be an unreasonable assumption given Foucault's statement that the 'purpose of history, guided by genealogy, is not to discover the roots of our identity, but to commit itself to its dissipation' (1984c: 95)!

xvi See especially Kemal (1999) for an interesting attempt to 'place' Foucault with Kant rather than with the plethora of postmodern opinion.

\section{Chapter 3: pages 52-79.}

xvii Paul Rabinow discuses in his introduction to the translation of Dits et écrits how Foucault wrote a letter the year before he died (which assumed the status of a will) in which he declared that did not want any posthumous publications. The four volumes of Dits et écrits were in obvious disregard of his wishes (Foucault, 1998: ix).

xviii This was similarly so in respect of Stephen Hawking's Brief History of Time that was bought in vast numbers but not often read to the end!

xix I agree with Hewitt that the translation of these terms such as genealogy or archaeology "jars in the mind': they are not naturally terms found in English-speaking social philosophy. He sees archaeology as a 'method of analysis that sites knowledge and its subjects by excavating the rules that form a particular discourse ... [such] rules establish both the boundaries dividing discourses and the continuities traversing [them]'. Alternatively, Hewitt sees genealogy as a way to trace discursive information 'to bring us a fuller understanding of presently constituted knowledge, a history of the present, and of its deployment as an instrument of power to promote 
authoritative pronouncements and mask criticism' (1983: 68). For Foucault, genealogy records 'the singularity of events ... in sentiments, love, conscience, instincts; it must be sensitive to their recurrence' (1984c: 76).

${ }^{x x}$ It is hard to escape the conclusion that while he can attack an epistemology that is committed to 'the individual, consciousness, and atemporal existence' Foucault's 'own thought remains deeply imprinted with the logical, almost axiomatic, structure of Cartesian rationalism' (MajorPoetzl, 1983: 161).

${ }^{x x i}$ Faubion provides an alternate list of possible 'Foucaults'. See his introduction to Michel Foucault: Aesthetics, Method, and Epistemology. He asks:

Who, or what is Michel Foucault? The possibilities already seem endless: structuralist, idealist, neoconservative, post-structuralist, antihumanist, irrationalist, radical relativist, theorist of power, missionary of transgression, aestheticist, dying man, saint, or, if nothing else, "postmodern". (1998: xiii)

xxii While Fox's survey of the application of Foucault within sociology is useful such a conclusion betrays a Francophobic aspect. For Fox, sociology is obviously and only English and North American. Where is the appreciation for Foucault's status within French social theory?

xxiii See especially Halperin (1995: $126 \mathrm{ff}$.) for a detailed examination of these ideas about Foucault and his resistance to biographical 'capture'.

${ }^{x x i v}$ The title of Descombes review 'Je m'en Foucault' is, in French, clever word play for 'Je m'en fous' means literally 'I don't give a fuck' but colloquially 'I don't give a damn'. While 'foutre' has the same meaning as fuck in English it does not carry the same expressive power in French.

${ }^{x \times v} \mathrm{~A}$ similar theme is expressed earlier by Wittgenstein who said that he:

... often compared language to a tool chest, containing a hammer, chisel, matches, nails screws, glue. It is not a chance that all these things have been put together - but there are important differences between the different tools -they are used in a family of ways though nothing could be more different than glue and a chisel. There is constant surprise at the new tricks language plays on us when we get into a new field. (Barrett, 1967: 1)

xxvi Gutting has also considered this distinction and wrote:

Foucault's writings tempt us to general interpretation along two primary axes. In the first dimension he appears as a philosopher historian, progressively developing a series of complementary historical methods: an archaeology of discourse in The History of madness, The Birth of the Clinic, The Order of Things, and the Archaeology of Knowledge; a genealogy of power relations in Discipline and Punish and The History of Sexuality 1; and a problematizations of ethics in The Use of Pleasure and The care of the Self. In the second dimension he appears as a historicist philosopher, offering, parallel to his methodological innovations, successively deeper and mutually supporting theories of knowledge, power, and the self. It is natural to combine these two dimensions in an overall interpretation of Foucault's work as a new comprehensive understanding of human reality supported by new methods of historical analysis. (1994: 2)

xxvii Foucault's own description of this is fascinating:

So you see then that this idea of passing me off as a "negator of history" is really amusing. I do nothing but history. It is interesting nonetheless to understand why I am 
accused of "negating" history. Evidently for the fact that I do not use those kinds of historical analyses - intangible, scared, and all-explanatory - to which, on the contrary, others turn. And these "others" are the ones who accuse me of negating history ... There you have it. In the end, this idea that I would refuse history comes not so much from professional historians as from philosophical circles, where they don't know in detail the kind of relationship, at once detached and reverent, that historical analysis requires. And so it is easy to conclude with the argument that I "negate" or "deny" history. (1991d: 129)

xxviii See Rorty's application of this anecdote of Hacking's about the 'baying mob' (1991: 198).

${ }^{x x i x}$ Foucault acknowledged that he:

...was wrong to present this "death" as something that was already in progress more or less during our time ... At the heart of the human sciences was not to be found the "human essence" ... men had never ceased constructing themselves ... that would never each an end and would never place us in the presence of something that would be "man." Man is an animal of experience, he is involved ad infinitum within a process that, by defining a field of objects, at the same time changes him, deforms him, transforms him and transfigures him as a subject. By speaking of the "death of man" in a way that was confused, simplifying and a bit prophetic, I wanted in substance to say these things: But it's not that I believe I touched them thoroughly. (1991d: 122-124)

\section{Chapter 4: pages 80-117.}

${ }^{x x x}$ Howard was one of Foucault's major translators.

xxxi I am indebted to my supervisor, Associate Professor Dr John Pratt, for the suggestion that the reviews of Foucault's books be considered separately. They do furnish another perspective on the previous chapter.

xxxii For example:

Whether they be images of madness, theories of pedagogy, definitions of sexuality, medical routines, military decisions, literary styles, research methods, views of language, or procedures for the organization of work, the conceptual systems within which an age is immured define its pattern of dominations. (Geertz, 1978: 3).

xxxiii The basis for my selection remains essentially personal and is based on an appreciation of the range of possible opinion and how salient it was to my intent to express the nature of that range per se.

${ }^{x x x i v}$ A Correction: For someone as respectful of detail as Megill so obviously is it is interesting to note his mistakes. He says that after Robert Mandrou's major French review of Madness and Civilization (Trois Clés pour comprendre la folie à l'époque classique, Annales, 17, 761: 771-2), published in 1962, 'the next review of any of Foucault's books in any disciplinary iournal appeared only in 1977, when the American Historical Review published a review of Surveiller et punir (1987: 126, my underlining). That is simply wrong, for example Matza in 1966 reviewed Madness and Civilization in American Sociological Review; Rieff, in 1967, reviewed Madness and Civilization in the American Academy of Political and Social Science, Annals; Peters, in 1971, reviewed Madness and Civilization in Sociological Review (19: 634-638), and Huppert wrote 'Divinatio et Eruditio: Thoughts on Foucault' for History and Theory: Studies in the Philosophy of History (13(3): 191-207) in 1974. Having made this assertion on page 126 two pages later Megill 
actually refers to Huppert's 1974 article! The point in mentioning this is not to score points off of Megill but rather to show how easy it is for scholars to be locked into the epistemology of their own discipline (one small piece of genealogical evidence perhaps?). This was a critique frequently expressed by Foucault (c.f., 1988d).

${ }^{x \times x}$ The phrase is from George Steiner's review of The Order of Things (1971: 29).

xxxvi Gordon describes this 'as one of the most powerful testamentary statements by a modern thinker, and as one of the literary summits of $20^{\text {th }}$ century philosophy'. (1988: 22). This is an accolade that more properly reflects Gordon's long standing defence of Foucault's work against some of the ad hominem attacks described here.

xxxvii Foucault defines what he means by 'techniques of the self' in this instructive paragraph:

Let me introduce a kind of auto-critique. It seems, according to some suggestions of Habermas, that one can distinguish three major types of technique: the techniques which permit one to produce, to transform, to manipulate things: the techniques which permit one to use sign systems: and finally, the techniques which permit one to determine the conduct of individuals, to impose certain ends or objectives. That is to say, techniques of production, techniques of signification or communication, and techniques of domination. But I became more and more aware that in all societies there is another type of technique; techniques which permit individuals to effect by their own means, a certain umber of operations on their own bodies,, their own souls, their own thoughts, their own conduct, and in this manner so as to transform themselves, modify themselves, and to gain a certain state of perfection, happiness, purity, supernatural power. Let's call these techniques technologies of the self. (1981c: 5 ).

\section{Chapter 5: pages 118-153.}

xxxviii This is the title of Foucault's series of lectures at the Collège de France in 1976. Davidson (1997: $1 \mathrm{ff}$.) describes the significance of these lectures in relation to the greater importance of Dits et écrits. The very title, of course, was naturally seized on by students of Foucault's whose Marxist intent to 'claim' Foucault was clear. The history of these events is well set out by Szakolczai (1998: 1404 ff.). See especially Foucault's Remarks on Marx (1991d) - conversations with Duccio Trombadori who was a journalist with the Italian Communist newspaper L'Unità.

xxxix Philp provides one of the clearest expositions of what Foucault meant by genealogy:

Genealogy involves a painstaking rediscovery of struggles, an attack on the tyranny of what he calls 'totalising discourses', and a rediscovery of fragmented, subjugated, local and specific knowledge. It is directed against the great truths, great systems, and great syntheses which mark the power/knowledge matrix of the modern order. It aims to unmask the operation of power to enable those who suffer from it to resist. (1985: 76)

${ }^{x 1}$ Nikolas Rose has sketched out the possibilities of this 'journey' in his book Powers of Freedom: Reframing Political Thought.

${ }^{x i}$ In The Archaeology of Knowledge Foucault acknowledged that a cry had gone up that he was murdering history (1972: 14).

xlii The 'trouble' that Foucault was to some American commentators is aptly seen in this mindless ad hominem retort from Davidson it is the cultural obligation of every twentieth- century French 
philosopher to seem brilliant, as it is the national duty of every twentieth-century British philosopher to seem sober' (1984: 109).

xliii Gearhart's analysis and description of Foucault's arguments about the importance of supplices, as a public spectacle and therefore a confirmation of power is a fascinating application of Foucault's work to Freudian themes of sado-masochism. Supplices were public spectacles, like the dismembering of Damiens in Discipline and Punish, which involved an inversion and mocking of authority but, nonetheless, confirmed its brutality (1997: $466 \mathrm{ff}$.).

xliv Smart commenting on another aspect of sociological research suggested that while: ... sociological work is likely to increase awareness of and sensitivity to human anguish and difficulties there exists in turn a substantial counter-pressure, namely a professional vested interest in both the persistence of problems and failures and the continuing availability of funds for their study. (1990: 398)

${ }^{\mathrm{x} \text { V }}$ Bové (1988) has set out a similar and more detailed criticism of Taylor than is relevant here.

xivi That Foucault is seen as a subversive intellect is well expressed in the outlandish comments of Connolly. He argues, for example, that in Foucault's world 'something is always out of joint ethically because it is impossible to combine all the elements of nobility perfectly in one site at one time' (1993: 378). That such an assertion betrays a raft of presumptions is self-evident. On that basis it can hardly stand as any effective criticism of Foucault rather than reveal itself as an expression of an intellectual impotence to grapple with the practices of power that Foucault attempted. Connolly talks of 'receiving' Foucault's 'political spirituality' as the starting point for his consideration! Foucault rejected Connolly's romanticized role of the intellectual.

\section{Chapter 6: pages 154-195.}

xvii The phrase 'what matter who's speaking' is a snippet from Samuel Beckett's Texts for Nothing (1974: 16). It poses the question about the relevance of 'authorship' and is one that echoes throughout Foucault's writing. When he wrote his famous paper 'What is an Author? part of his intent was to remove, as he said, the 'tiresome repetition' of questions about who was the real author (1977a). His notorious 'reticence about himself' was an intrinsic part of his thinking about any 'intellectual itinerary'; of which he argued 'that neither a thinker's mental stages nor their links to deeper personal needs tell us much that counts about the meaning of ... [an author's] ideas' (Seigel, 1990: 273). The allusive nature of Beckett's prose and ideas thus mirrors something of Foucault's own style.

xlviii Giovanna Procacci, in a private conversation, confirmed that Foucault wept at Baudrillard's personal attack.

${ }^{x}$ A A phrase derived from Procacci, 1994)

'The international exchange of managerial ideas about how to make the new deregulated managerial system work has all the hallmarks of a 'crusade'! The gurus of the new order are regularly featured on TV and in the popular press. How these ideas are 'marketed' is extraordinary. It can hardly be seen though as a conspiracy, which some left-wing writers are prone to assume; it is too open and relentless for that! Tangential but related to this marketing of ideas is Hermer and Hunt's preliminary explorations of official graffiti as 'an exemplary form of governance in post-modern modernity' (1996: 477). 


\footnotetext{
"Habermas was impatient with how the 'foreground contingencies in the world were denied any legitimacy and replaced with 'mysteriously encoded contingencies found in the disclosure of the world'. Certainly for him such 'other' reasoning had 'the effect of extinguishing the last sparks of utopian thinking and western culture's confidence in itself' (1986: 3 ). See White (1988a and $1988 \mathrm{~b})$ for a different perspective on Habermas' pessimism and the possibility of creating a 'legitimate commonality'.

lii It has been amazing how powerful that metaphor has been in capturing the minds of scholars (especially in Criminology, but no less in Social Policy) who have interpreted contemporary penal patterns and social systems according to that metaphor of the 'carceral archipelago'.
}

\section{Chapter 7: pages 196-238.}

liii I will apply this term 'self-referent community' to refer to the wide range of these political collectivities. The term can refer to commercial groupings (the 'organization'), groups with a common purpose both practical and ideological, and also communities of origin. It is from the last that we get the idea of tribalization. The singular importance is that while I think it is a clumsy and grab-bag term it does refer to those groups who seek to govern below an allegiance to the nationstate and citizenship rights.

liv This is Rose's phrase (1996a: 347).

${ }^{N}$ Hillyard and Watson refer to the "tyranny of the binary structuring of thought in modern society. In each binary opposition there is a hierarchical privileging of one side against the other. The discipline of social policy is replete with oppositions with one side carrying overtones of moral superiority' (1996: 324).

Ivi One of the practical expressions of 'individualized' welfare is the explosion in home security firms and the demands for prudentialism - now the hallmark of the 'responsible individual' (c.f., O’Malley, 1996: 201-202).

Ivii For a summary of some of the most recent debates about citizenship (which has spawned a vast literature) see Bader (1995).

Ivii Omnes et singulatim was the title of one of Foucault's lectures in his last series which had the overall title of 'The government of one's self and others' (Burchell, Gordon and Miller, 1991: 2-3; see Foucault, 1981b).

lix Certainly Habermas was less hopeful, and presumed that the 'exhaustion of utopian energies' was not a 'passing mood' and maybe there was 'a fundamental change of modern timeconsciousness in general' that vitiated the normative foci of critical theorists (1986: 3 ).

\section{Chapter 8: pages 239-248.}

\section{${ }^{1 x}$ See Thus Spake Zarathustra, 41.}

${ }^{\mathrm{Ixi}}$ A palimpsest is an original manuscript that is effaced and overwritten. The imagery seems singularly appropriate in this discussion of risk and dependency, particularly as these concepts of risk are continually being 'overwritten' to serve new political ends. Zygmunt Bauman has coined the phrase 'palimpsest identity' to refer to an aspect of personal self-image 'where the art of forgetting is an asset' within 'postmodern uncertainty' (1997: 25). 


\section{Bibliography}

Aladjem, T. K. (1996) 'The Philosopher's Prism: Foucault, Feminism, and Critique', in Hekman, S. J. (ed.) Feminist Interpretations of Michel Foucault. Pennsylvania: The Pennsylvania State University Press. Pp. 283-298.

Alford, C. F. (2000) 'What would it matter if everything Foucault said about prison were wrong? Discipline and Punish after twenty years', Theory and Society, 29: 125-146.

Allen, B. (1991) 'Government in Foucault', Canadian Journal of Philosophy, 21(4): 421-440.

Allen, B. (1998) 'Foucault and Modern Political Philosophy', in Moss, J. (ed.) The Later Foucault. London: Sage Publications. Pp. 164-198.

Antonio, R. J. (1998) 'Mapping Postmodern Social Theory', in Sica, A. (ed.) What is Social Theory: The Philosophical Debates? Malden, Mass: Blackwell. Pp. 35-52.

Arac, J. (1980) 'The Function of Foucault at the Present Time', Humanities in Society, 3: 7386.

Arac, J. (1991) (ed.) After Foucault: Humanistic Knowledge, Postmodern Challenges. New Brunswick: Rutgers University Press.

Arac, J. (1994) 'Foucault and Central Europe: A Polemical Speculation', boundary 2, 19(4): 197-210.

Archambault, P. (1985) 'Michel Foucault's Last Discourse on Language', Papers on Language and Literature, 21(4): 433-442.

Arendt, H (1959) The Human Condition. New York: Doubleday Anchor Books.

Armstrong, D. (1985) 'Review Essay: the subject and the social in medicine: an appreciation of Michel Foucault', Sociology of Health and IIIness, 7(1): 116.

Asen, R. (1996) 'Constructing the Objects of Our Discourse: The Welfare Wars, the Orphanage and the Silenced Welfare Mom', Political Communication, 13: 293-307.

Ashenden, S. and Owen, D. (1999) (eds.) Foucault Contra Habermas. London: Sage Publications

Atkins, E. (1993) Vita \& Virginia: Adapted from the correspondence between Virginia Woolf and Vita Sackville-West. London: Samuel French.

Babich, B. E. (1992) 'Questioning Heidegger's Silence: A Postmodern Typology', in Dallery, A. B. and Scott, C. E. with Roberts, P. H. (eds.) Ethics and Danger: Essays on Heidegger and Continental Thought. New York, Albany: State University of New York Press. Pp. 83-106.

Baert, P. (1998) 'Foucault's History of the Present as Self-referential Knowledge Acquisition', Philosophy and Social Criticism, 24(6): 111-126.

Barrett, C. (1967) (ed.) Wittgenstein: Lectures and Conversations. Berkeley: University of California Press.

Barry, A. Osborne, T. and Rose, N. (1993) 'Liberalism, Neo-Liberalism and Governmentality: Introduction', Economy and Society, 22(3): 265-266.

Barry, N. (1997) 'Conservative Thought and the Welfare State', Political Studies, 45(2): 331345. 
Baudrillard, J. (1993) Symbolic Exchange and Death. London: Sage Publications.

Bauman, Z. (1992) Intimations of Postmodernity. London: Routledge.

Bauman, Z. (1997) Postmodernity and its Discontents. New York: New York University Press.

Beaud, P. and Panese, F. (1995) 'From one galaxy to another: the trajectories of French intellectuals', Media, Culture and Society, 17(3): 385-412.

Beck, U. (1992) Risk Society: Towards a New Modernity. London: Sage Publications.

Beck, U. (1995a) Ecological Politics in an Age of Risk. Cambridge: Polity Press.

Beck, U. (1995b) 'Freedom For Technology', Dissent, Fall: 503-507.

Beck, U. (1997a) 'Capitalism without Work', Dissent, 44(1): 51-56.

Beck, U. (1997b) The Reinvention of Politics: Rethinking Modernity in the Global Social Order. Cambridge: Polity Press.

Beck, U. Giddens, A. and Lash, S. (1994) (eds.) Reflexive Modernization: Politics, Tradition And Aesthetics In The Modern Social Order. Cambridge: Polity Press.

Berard, T. J. (1999) 'Michel Foucault, The History of Sexuality, and the Reformulation of Social Theory', Journal for the Theory of Social Behaviour, 29(3): 203-227.

Bernauer, J. (1982) 'Foucault's Political Analysis', International Philosophical Quarterly, 22: 87-95.

Bernauer, J. (1983) 'America's Foucault', Man and World, 16(4): 389-405.

Bernauer, J. (1986) 'The Sounds of Silence', Commonweal, 113: 17-20.

Bernauer, J. (1987) 'The Prisons of Man: An Introduction to Foucault's Negative Theology', International Philosophical Quarterly, XXVII(4): 367-380

Bernauer, J. (1988) 'Beyond Life and Death: on Foucault's Post-Auschwitz Ethic', Philosophy Today, 32(2-4): 128-141.

Bernauer, J. W. and Mahon, M. (1994) 'The ethics of Michel Foucault', in Gutting, G. (ed.) The Cambridge Companion to Foucault. Cambridge: Cambridge University Press. Pp. 141158.

Bernstein, R. J. (1994) 'Foucault: Critique as a Philosophical Ethos', in Kelly, M. (ed.) Critique and Power: Recasting the Foucault/Habermas Debate. Cambridge, Mass: The MIT Press. Pp. 211-241.

Bersani, L. (1995) 'Foucault, Freud, Fantasy, and Power', Gay and Lesbian Quarterly: Journal of Gay and Lesbian Studies, 2(1-2): 11-33.

Bevir, M. (1999) 'Foucault and Critique: Deploying Agency against Autonomy', Political Theory, 27(1): 65-84.

Blair, C. and Cooper, M. (1987) 'The Humanist Turn in Foucault's Rhetoric of Inquiry', Quarterly Journal of Speech, 73: 151-171.

Boston, J. Martin, J. Pallot, J. and P. Walsh. (1996) (eds.) Public Management: The New Zealand Model. Auckland: Oxford University Press. 
Bottoms, A. E. (1983) 'Neglected Features of Contemporary Penal Systems', in Garland, D. and Young, P. (eds.) The Power to Punish: Contemporary Penality and Social Analysis. London: Heinemann Educational books Ltd. Pp. 166-202.

Bouchard, D.F. (1977) Language, Counter-Memory, Practice: Selected Essays and Interviews with Michel Foucault. Ithaca, New York: Cornell University Press.

Bouchard, D. F. (1980) 'For Life and Action: Foucault, Spectacle, Document', Oxford Literary Review, 4: 20-28.

Bovè, P. A. (1980) 'The End of Humanism: Michel Foucault and the Power of Disciplines', Humanities in Society, 3: 23-40

Bovè, P. A. (1988) 'Foreword: The Foucault Phenomenon: the problematics of style', Deleuze, G. Foucault. Minneapolis: University of Minneapolis Press. Pp. vii-xliv.

Brenner, N. (1994) 'Foucault's New Functionalism', Theory and Society, 23(5): 679-709.

Burchell, G. (1991) 'Civil society and the 'system of natural liberty', in Burchell, G. Gordon, C and Miller, P. (eds.) The Foucault Effect: Studies in Governmentality. Hemel Hempstead: Harvester Wheatsheaf. Pp. 119-150.

Burchell, G. (1993) 'Liberalism, neo-liberalism and governmentality: introduction', Economy and Society, 22(3): 267-282.

Burchell, D. (1995) 'Social Citizenship and Social justice: An Unhappy Coupling”, Social Policy Research Centre: Reports and Proceedings \# 122. Sydney: University of New South Wales. Pp. 35-46.

Burchell, D. (1996) 'Liberal government and the techniques of the self', in Barry, A. Osborne, T. and Rose, N. (eds.) Foucault and Political Reason: Liberalism, Neo-Liberalism and Rationalities of Government. Chicago: The University of Chicago Press. Pp. 19-36.

Burke, S. (1992) The Death and Return of the Author: Criticism and Subjectivity in Barthes, Foucault and Derrida, Edinburgh: Edinburgh University Press.

Campbell, D. (1998) 'Why Fight: Humanitarianism, Principles and Post-structuralism', Millennium: Journal of International Studies, 27(3): 497-521.

Caputo, J. and Yount, M. (1993) (eds.) Foucault and the Critique of Institutions. Pennsylvania: Pennsylvania State University Press.

carlos jacques, T. (1991) 'whence does the critic speak? A study of Foucault's genealogy', Philosophy and Social Criticism, 17(4): 325-344.

Carrette, J. R. (1999) (ed.) Religion and Culture by Michel Foucault. Manchester: Manchester University Press.

Carter, J. (1998) (ed.) Postmodernity and the Fragmentation of Welfare. London and New York: Routledge.

Castel, R. (1991) 'From dangerousness to risk', in Burchell, G. Gordon, C and Miller, P. (eds.) The Foucault Effect: Studies in Governmentality. Hemel Hempstead: Harvester Wheatsheaf. Pp. 281-298.

Castel, R. (1994) '"Problematization" as a Mode of Reading History', in Goldstein, J. (ed.) Foucault and the Writing of History. Oxford: Basil Blackwell Ltd. Pp. 237-252.

Chambon, A. S. Irving, A. and Epstein, L. (1999) (eds.) Reading Foucault for Social Work. New York: Columbia University Press. 
Clark, M. (1983) (ed.) Michel Foucault, An Annotated Bibliography: Tool Kit for a New Age. New York: Garland Publishing.

Cohen, E. (1988) 'Foucauldian necrologies: 'gay' 'politics'? politically gay?', Textual Practice, 2(1): 87-101.

Cohen, M. J. (1997) ‘Risk Society And Ecological Modernisation’, Futures, 29(2): 105-119.

Cohen, S. (1979) 'The Punitive City: Notes On The Dispersal Of Social Control', Contemporary Crises, 3: 339-363.

Cohen, S. (1985) Visions of Social Control: Crime, Punishment and Classification. Oxford: Polity Press.

Colapietro, V. (1998) 'American Evasions of Foucault', The Southern Journal of Philosophy, 36: 329-351.

Connolly, W. E. (1983) 'Discipline, Politics, and Ambiguity', Political Theory, 11(3): 325-341.

Connolly, W. E. (1991) Identity/Difference: Democratic Negotiations of Political Paradox. Ithaca: Cornell University Press.

Connolly, W. E. (1993a) 'Beyond Good and Evil: The Ethical Sensibility of Michel Foucault', Political Theory, 21(3): 365-389.

Connolly, W. E. (1993b) The Augustinian Imperative: A Reflection on the Politics of Morality. London: Sage Publications.

Cook, D. (1990) 'Remapping Modernity', British Journal of Aesthetics, 30(1): 35-45.

Cook, D. (1993) The Subject Finds a Voice: Foucault's Turn Towards Subjectivity. New York: Peter Lang.

Cooke, M. (1997) 'Authenticity and Autonomy', Political Theory, 25(2): 258-288.

Cousins, M. and Hussain, A. (1984) Michel Foucault. Houndmills, Basingstoke: Macmillan Education Ltd.

Cousins, M. and Hussain, A. (1986) 'The Question of Ideology: Althusser, Pecheux and Foucault', The Sociological Review Monograph, 32: 158-179.

Culpitt, I. (1992) Welfare and Citizenship: Beyond the crisis of the welfare state. London: Sage Publications.

Culpitt, I. (1999) Social Policy and Risk. London: Sage Publications.

Dahrendorf, R. (1995) LSE: A History of the London School of Economics and Political Science 1895-1995. Oxford: Oxford University Press.

Davidson, A. (1984) 'Conceptual Analysis and Conceptual History: Foucault and Philosophy', Stanford French Review, 8(1): 105-122.

Davidson, A. (1997) (ed.) Foucault And His Interlocutors. Chicago: The University of Chicago Press.

Davis, G. Sullivan, B. and Yeatman, A. (1997) (eds.) The New Contractualism? Melbourne: Macmillan Education.

Deacon, B. (1997) Global Social Policy: International Organizations and the Future of Welfare. London: Sage Publications. 
Dean, H. and Taylor-Gooby, P. (1992) (eds.) Dependency Culture: The Explosion of a Myth. London: Harvester Wheatsheaf.

Dean, H. and Melrose, M. (1999) Poverty, Riches and Social Citizenship. Houndmills, Basingstoke: Macmillan Press.

Dean, M. (1986) 'Foucault's Obsession with Western Modernity', Thesis Eleven, 14: 44-61.

Dean, M. (1991) The Constitution of Poverty: Toward a Genealogy of Liberal Governance. London: Routledge.

Dean, M. (1992) 'A genealogy of the government of poverty', Economy and Society, 21(3): 215-251.

Dean, M. (1994a) Critical and Effective Histories: Foucault's Methods and Historical Sociology. London: Routledge.

Dean, M. (1994b) "'A social structure of many souls": Moral regulation, government and selfformation', Canadian Journal of Sociology, 19(2): 145-168.

Dean, M. (1995a) 'Governing the unemployed self in an active society', Economy and Society, 24(4): 559-583.

Dean, M. (1995b) 'For a Political Ontology of Ourselves', Political Expressions, 1(1): 17-30.

Dean, M. (1996) 'Putting the technological into government', History of the Human Sciences, $9(3): 47-68$.

Dean, M. (1997) 'Sociology after Society', in Owen, D. (ed.) Sociology after Postmodernism. London: Sage Publications. Pp. 205-228.

Dean, M. (1998) 'Questions of Method', in Velody, I. and Williams, R. (eds.) The Politics of Constructionism. London: Sage Publications. Pp. 181-199.

Dean, M. (1999a) Governmentality: Power and Rule in Modern Society. London: Sage Publications.

Dean, M. (1999b) 'Normalising Democracy: Foucault and Habermas on Democracy Liberalism and Law', in Ashenden, S. and Owen, D. (eds.) Foucault Contra Habermas. London: Sage Publications. Pp. 166-194.

Dean, M. and Hindess, B. (1998) (eds.) Governing Australia: Studies in Contemporary Rationalities of Government. Cambridge: Cambridge University Press.

Deflem, M. (1994) 'Social Control and the Theory of Communicative Action', International Journal of the Sociology of Law, 22(4): 355-373.

Delaporte, F. (1998) 'Foucault, epistemology and history', Economy and Society, 27(2\&3): 285-297.

Deleuze, G. (1988) Foucault. Minneapolis: University of Minneapolis Press.

Deleuze, G. (1992) 'What is a dispositif?', in Armstrong, T. J. (ed.) Michel Foucault Philosopher. New York: Routledge. Pp. 159-166.

Deleuze, G. (1995) Negotiations: 1972-1990. New York: Columbia University Press.

Deleuze, G. (1997) Essays Critical and Clinical. Minneapolis: University of Minnesota Press.

Derrida, J. (1982) Margins of Philosophy. Chicago: University of Chicago Press. 
De Oliveira, N. (1997) Review of M. Kelly (ed.) Critique and Power: Recasting the Foucault/Habermas Debate. Cambridge: MIT Press, Constellations, 4(1): 141-143.

De Sousa Santos, B. (1995) Towards a New Common Sense: Law, Science and Politics in the Paradigmatic Transition. New York: Routledge.

Descombes, V. (1987) 'Je m'en Foucault', (Review Article) London Review of Books. $5^{\text {th }}$ March. Pp. 20-21.

Dews, P. (1989) 'The Return of the Subject in Late Foucault', Radical Philosophy, 51: 37-41.

Digeser, P. (1992) 'The Fourth Face of Power', The Journal of Politics, 54(4): 977-1007

Donzelot, J. (1977) 'An Antisociology', Semiotext(e), 11(3): 27-44.

Donzelot, J. (1979) The Policing of Families. New York: Pantheon Books.

Donzelot, J. (1988) 'The promotion of the social', (trans. G. Burchell) Economy and Society, 17(3): 395-427.

Donzelot, J. (1991) 'The mobilization of society', in Burchell, G. Gordon, C and Miller, P. (eds.) The Foucault Effect: Studies in Governmentality. Hemel Hempstead: Harvester Wheatsheaf. Pp. 69-179.

Doxiadis, K. (1997) 'Foucault and the three-headed king: state, ideology and theory as targets of critique', Economy and Society, 26(4): 518-545.

Dreyfus, H. L. and Rabinow, P. (1982) Michel Foucault: Beyond Structuralism and Hermeneutics. Chicago: Chicago University Press.

Dreyfus, H. L. and Rabinow, P. (1986) 'What is Maturity? Habermas and Foucault on 'What is Enlightenment?', in Hoy, D. C. (ed.) Foucault A Critical Reader. Oxford: Blackwell. Pp. 109121.

Drover, G. and Kerans, P. (1993) (eds.) New Approaches to Welfare Theory. Aldershot, Hants: Edward Elgar.

Drucker, P. (1969) 'The sickness of government', The Public Interest, 14: 3-23.

Dumm, T. L. (1988) 'The Politics of Post-Modern Aesthetics', Political Theory, 16(2): 209-228.

Dumont, C. (1998) 'The Analytical and Political Utility of Poststructuralism: Considering

Affirmative Action', Canadian Journal of Sociology, 23(2-3): 217-237.

Eribon, D. (1991) Michel Foucault. Cambridge, Mass: Harvard University Press.

Esping-Andersen, G. (1996) Welfare States in Transition: National Adaptations in Global Economies. London: Sage Publications.

Ewald, F. (1991) 'Insurance and Risk', in Burchell, G. Gordon, C and Miller, P. (eds.) The Foucault Effect: Studies in Governmentality. Hemel Hempstead: Harvester Wheatsheaf. Pp. 197-210.

Ewald, F. (1992) 'A power without an exterior', in Armstrong, T. J. (ed.) Michel Foucault Philosopher. New York: Routledge. Pp. 169-175.

Ewald, F. (1999) 'Foucault and the Contemporary Scene', Philosophy and Social Criticism, 25(3): 81-91. 
Fackenheim, E. (1985) 'The Holocaust and Philosophy', The Journal of Philosophy, LXXXII(10): 505:515.

Faubion, J. D. (1998) (ed.) Michel Foucault: Aesthetics, Method and Epistemology: Essential Works of Foucault 1954-1984 (Vol. 2). New York: The Free Press.

Fink-Eitel, H. (1992) Foucault: An Introduction. Philadelphia: Pennbridge.

Fisher, D. D. (1998) 'Should Feminists "Forget Foucault"?' Studies in $20^{\text {th }}$ Century Literature, 22(1): 227-244.

Fleming, M. (1996) 'Working In The Philosophical Discourse Of Modernity: Habermas, Foucault, and Derrida', Philosophy Today, 40(1): 169-178.

Flynn, T. (1985) 'Truth and Subjectivation in the Later Foucault', The Journal of Philosophy, LXXXII, 10: 531-40.

Flynn, T. (1987) 'Michel Foucault and the Career of the Historical Event', in Danenhaner, B. (ed.), At the Nexus of Philosophy and History. Athens, GA: University of Georgia Press. Pp. 178-200.

Flynn, T. (1989) 'Foucault and the Politics of Postmodernity', NOUS, 23(2): 187-198.

Flynn, T. (1991) 'Foucault and the Spaces of History', The Monist, 165-186.

Flynn, T. (1997) Sartre, Foucault, and Historical Reason, Vol. One. Chicago: University of Chicago Press.

Flyvbjerg, B. (1998) 'Habermas and Foucault: Thinkers for Civil Society', British Journal of Sociology, 49(2): 210-233.

Foucault, M. (1965) Madness and Civilization: A History of Insanity in the Age of Reason. New York: Vintage Books.

Foucault, M. (1971a) 'Orders of discourse: Inaugural Lecture', Social Service Information, 10(2): 7-30.

Foucault, M. (1971b) 'Monstrosities in Criticism', diacritics, 1: 57-60.

Foucault, M. (1972) The Archaeology of Knowledge \& The Discourse on Language. London: Tavistock Publications.

Foucault, M. (1973) The Birth of the Clinic. London: Tavistock.

Foucault, M. (1977a) 'What is an Author?', in Bouchard, D.F. (ed.) Language, CounterMemory, Practice: Selected Essays and Interviews with Michel Foucault. Ithaca: Cornell University Press. Pp. 113-138.

Foucault, M. (1977b) 'Intellectuals and Power', in Bouchard, D.F. (ed.) Language, CounterMemory, Practice: Selected Essays and Interviews with Michel Foucault. Ithaca: Cornell University Press. Pp. 205-217.

Foucault, M. (1977c) 'Revolutionary Action: "Until Now"', in Bouchard, D.F. (ed.) Language, Counter-Memory, Practice: Selected Essays and Interviews with Michel Foucault. Ithaca: Cornell University Press. Pp. 218-233.

Foucault, M. (1977d) 'Power and Sex: An Interview with Michel Foucault', Telos, 32: 152-161.

Foucault, M. (1978) 'The Eye of Power', Semiotext(e), 111(2): 6-19. 
Foucault, M. (1979a) Discipline and Punish: The Birth of the Prison. New York: Vintage Books.

Foucault, M. (1979b) ‘On Governmentality’, Ideology and Consciousness, 6: 5-21.

Foucault, M. (1979c) 'My Body, This Paper, This Fire', Oxford Literary Review, 4(1): 5-28.

Foucault, M. (1980a) Gordon, C. (ed.) Power/Knowledge: Selected Interviews and Other Writings 1972-1977. Brighton: The Harvester Press.

Foucault, M. (1980b) 'War in the Filigree of Peace: Course Summary', Oxford Literary Review, 4: 15-19.

Foucault, M. (1980c) 'The History of Sexuality: Interview', Oxford Literary Review, 12 March 1977: 15-19.

Foucault, M. (1981a) The History of Sexuality Volume One: An Introduction. London: Pelican Books.

Foucault, M. (1981b) 'Omnes et Singulatim: Towards a Criticism of 'Political Reason", The Tanner Lectures on Human Values (Part II). Salt Lake City: University of Utah Press. Pp. 223-254.

Foucault, M. (1981c) 'Sexuality and Solitude: Michel Foucault and Richard Sennett', London Review of Books, $21^{\text {st }}$ May $3^{\text {rd }}$ June: $3-7$.

Foucault, M. (1983) 'The Subject and Power', Dreyfus, H. L. and Rabinow, P. (2nd edition) (eds.) Michel Foucault: Beyond Structuralism and Hermeneutics. Chicago: The University of Chicago Press. Pp. 208-226.

Foucault, M. (1984a) 'What is Enlightenment', in Rabinow, P. (ed.) The Foucault Reader. New York: Pantheon Books. Pp. 32-50.

Foucault, M. (1984b) 'Truth and Power', in Rabinow, P. (ed.) The Foucault Reader. New York: Pantheon Books. Pp. 51-75.

Foucault, M. (1984c) 'Nietzsche, Genealogy, History', in Rabinow, P. (ed.) The Foucault Reader. New York: Pantheon Books. Pp. 76-100.

Foucault, M. (1984d) 'The Body of the Condemned', in Rabinow, P. (ed.) The Foucault Reader. New York: Pantheon Books. Pp. 170-178.

Foucault, M. (1984e) 'On the Genealogy of Ethics: An Overview of Work in Progress', in Rabinow, P. (ed.) The Foucault Reader. New York: Pantheon Books. Pp. 340-372

Foucault, M. (1984f) 'Polemics, Politics, and Problemizations', in Rabinow, P. (ed.) The Foucault Reader. New York: Pantheon Books. Pp. 381-390.

Foucault, M. (1984g) 'Space knowledge, and Power', in Rabinow, P. (ed.) The Foucault Reader. New York: Pantheon Books. Pp. 239-256.

Foucault, M. (1984h) 'The Regard for Truth: Interview between Michel Foucault and François Ewald', Art and Text, 16: 24-31.

Foucault, M. (1984i) 'Preface to The History of Sexuality, Volume 11', in Rabinow, P. (ed.) The Foucault Reader. New York: Pantheon Books. Pp. 333-339.

Foucault, M. (1985a) The Use of Pleasure: The History of Sexuality Volume 2. London:

Penguin Books. 
Foucault, M. (1985b) 'Michel Foucault - Final Interview', Raritan, 5(1): 1-13.

Foucault, M. (1986) 'Kant on Enlightenment and Revolution', (trans. Colin Gordon) Economy and Society, 15(1): 88-96.

Foucault, M. (1987a) Mental IIIness and Psychology. Berkeley: University of California Press.

Foucault, M. (1987b) 'The ethic of care for the self as a practice of freedom: an interview with Michel Foucault, January 20,1984', conducted by Raúl Fornet-Betancourt, et al., Philosophy and Social Criticism, 12(2-3): 113-131.

Foucault, M. (1988a) 'Social Security', in Kritzman, L. (ed.) Michel Foucault, Politics, Philosophy, Culture: Interviews and Other Writings 1977-1984. New York: Routledge. Pp. 159-177.

Foucault, M. (1988b) 'Technologies of the Self', in Martin, L. H. Gutman, H. and Hutton, P. H. (eds.) Technologies of the Self: A Seminar with Michel Foucault. Amherst: The University of Massachusetts Press. Pp. 16-49.

Foucault, M. (1988c) 'The Political Technology of Individuals', in Martin, L. H. Gutman, H. and Hutton, P. H. (eds.) Technologies of the Self: A Seminar with Michel Foucault. Amherst: The University of Massachusetts Press. Pp. 145-162.

Foucault, M. (1988d) 'The Masked Philosopher', in Kritzman, L. (ed.) Michel Foucault, Politics, Philosophy, Culture: Interviews and Other Writings 1977-1984. New York: Routledge. Pp. 323-330.

Foucault, M. (1988e) 'The Return of Morality', in Kritzman, L. (ed.) Michel Foucault, Politics, Philosophy, Culture: Interviews and Other Writings 1977-1984. New York: Routledge. Pp. 242-254.

Foucault, M. (1988f) 'Practicing Criticism', in Kritzman, L. (ed.) Michel Foucault, Politics, Philosophy, Culture: Interviews and Other Writings 1977-1984. New York: Routledge. Pp. 152-156.

Foucault, M. (1988g) 'The Concern for Truth', in Kritzman, L. (ed.) Michel Foucault, Politics, Philosophy, Culture: Interviews and Other Writings 1977-1984. New York: Routledge. Pp. 255-267.

Foucault, M. (1989) Foucault Live (Interviews, 1966-84). New York: Columbia University, Semiotext(e) Foreign Agents Series.

Foucault, M. (1990) The History of Sexuality Volume One: An Introduction. New York: Vintage: Pelican Books.

Foucault, M. (1991a) 'Politics and the study of discourse' in Burchell, G. Gordon, C and Miller, P. (eds.) The Foucault Effect: Studies in Governmentality. Hemel Hempstead: Harvester Wheatsheaf. Pp. 53-72.

Foucault, M. (1991b) 'Questions of Method' in Burchell, G. Gordon, C and Miller, P. (eds.) The Foucault Effect: Studies in Governmentality. Hemel Hempstead: Harvester Wheatsheaf. Pp. 73-86.

Foucault, M. (1991c) 'Governmentality', in Burchell, G. Gordon, C and Miller, P. (eds.) The Foucault Effect: Studies in Governmentality. Hemel Hempstead: Harvester Wheatsheaf. Pp. 87-104.

Foucault, M. (1991d) Remarks on Marx: Conversations with Duccio Trombadori. New York: Columbia University: Semiotext(e) Foreign Agents Series. 
Foucault, M. (1991e) 'Michel Foucault on Attica', Social Justice, 18(3): 26-34.

Foucault, M. (1991f) 'Questions of Method: An Interview with Michel Foucault', in Baynes, K. Bohman, J. and McCarthy, T. (eds.) Philosophy: End or Transformation. Cambridge, Mass: The MIT. Press. Pp.100-117.

Foucault, M. (1993) 'About The Beginning Of The Hermeneutics Of The Self', Political Theory, 21(2): 198-227.

Foucault, M. (1994) The Order of Things: An Archaeology of the Human Sciences. New York: Vintage Books.

Foucault, M. (1995) 'Madness, the Absence of Work', Critical Inquiry, 21(2): 290-298.

Foucault, M. (1997a) 'What is Critique', in The Politics of Truth. New York, Columbia University, Semiotext(e) Foreign Agents Series. Pp. 97-104.

Foucault, M. (1997b) 'Madness, the Absence of Work', in Davidson, A. I. (ed.) Foucault And His Interlocutors. Chicago: The University of Chicago Press. Pp. 146-182.

Foucault, M. (1997c) Ethics Subjectivity and Truth: Essential Works of Foucault 1954-1984 (Vol. 1) (P. Rabinow ed.). New York: The Free Press.

Foucault, M. (1998) Aesthetics, Method and Epistemology: Essential Works of Foucault 19541984 (Vol. 2) (J. D. Faubion ed.). New York: The Free Press.

Fox, N. J. (1998) 'Foucault, Foucauldians and Sociology', British Journal of Sociology, 49(3): 415-433.

Fraser, M. (1997) 'Feminism, Foucault and Deleuze', Theory, Culture \& Society, 14(2): 23-37.

Fraser, N. (1981) 'Foucault on Modern Power: Empirical Insights and the Normative Confusions', Praxis International, 1(3): 272-287.

Fraser, N. (1987) 'Women, Welfare and the Politics of Need Interpretation', Hypatia: A Journal of Feminist Philosophy, 2(1): 103-121.

Fraser, N. (1989a) 'Talking about Needs: Interpretive Contests as Political Conflicts in Welfare-State Societies', Ethics, 99(2): 291-313.

Fraser, N. (1989b) Unruly Practices: Power, Discourse and Gender in Contemporary Social Theory. Cambridge: Polity Press.

Fraser, N. (1992) 'Rethinking the Public Sphere: A Contribution to the Critique of Actually Existing Democracy', in Calhoun, C. J. (1992) (ed.) Habermas and the Public Sphere. Cambridge, Mass: The MIT Press. Pp. 109-142.

Fraser, N. (1993) 'Clintonism, Welfare, and the Antisocial Wage: The Emergence of a Neoliberal Political Imaginary', Rethinking Marxism, 6(1): 9-23.

Fraser, N. (1995a) 'Politics, culture, and the public sphere: toward a postmodern conception', in Nicholson, L. and Seidman, S. (eds.) Social postmodernism: Beyond identity politics. Cambridge: Cambridge University Press. Pp. 287-312.

Fraser, N (1995b) 'From Redistribution to Recognition - Dilemmas of Justice in a PostSocialist Age', New Left Review, 212: 68-93.

Fraser, N (1996) 'Reply to Zylan', Signs, 21(2): 531-536. 
Fraser, N (1997) Justice Interruptus: Critical Reflections on the "Postsocialist" Condition. New York \& London: Routledge.

Fraser, N. and Gordon, L. (1994a) 'A Genealogy of Dependency: Tracing a Keyword of the U.S. Welfare State', Signs, 19(2): 309-336.

Fraser, N. and Gordon, L. (1994b) "Dependency" Demystified: Inscriptions of Power in a keyword of the Welfare State', Social Political International Studies in Gender, State and Society, 1(1): 4-31.

Free, G, (1993) 'On the Social History of Sociology: From Merton to Foucault via Durkheim', Current Perspectives in Social Theory, 13: 185-204.

Freundlieb, D. (1988) 'Rationalism v. Irrationalism? Habermas's Response to Foucault', Inquiry, 31(2): 171-192.

Fukuyama, F. (1992) The end of history and the last man. New York: Free Press.

Gandal, K. (1986) 'Foucault's Intellectual Work and Politics', Telos, 67: 121-134.

Gane, M. (1986) 'The form of Foucault', Economy and Society, 15(1): 110-122.

Garland, D. (1990) Punishment and Modern Society. Oxford: Clarendon Press.

Garland, D. (1997) 'Governmentality' and the problem of crime: Foucault, criminology, sociology', Theoretical Criminology, 1(2): 173-214.

Gearhart, S. (1995) 'Foucault's Response to Freud: Sado-Masochism and the Aestheticization of Power', Style, 29(3): 389-403.

Gearhart, S. (1997) 'The Taming of Michel Foucault: New Historicism, Psychoanalysis, and the Subversion of Power', New Literary History, 28: 457-480.

George, V. and Taylor-Gooby, P. (1996) (eds.) European Welfare Policy: Squaring the Welfare Circle. Houndmills, Basingstoke, Hampshire: Macmillan Press Ltd.

Giddens, A. (1990) The Consequences of Modernity. Cambridge: Polity Press.

Giddens, A. (1991) Modernity and Self-Identity. Cambridge: Polity Press.

Giddens, A. (1994a) 'Brave New World: The New Context of Politics', in Miliband, D. (ed.) Reinventing the Left. Cambridge, Mass: Polity Press. Pp. 21-38.

Giddens, A. (1994b) Beyond Left and Right: The Future of Radical Politics. Stanford: Stanford University Press.

Giddens, A. (1994c) 'Living in a Post-Traditional Society', in Beck, U. Giddens, A. and Lash, S. (eds.) Reflexive Modernization: Politics, Tradition and Aesthetics in the Modern Social Order. Cambridge: Polity Press. Pp. 56-109.

Giddens, A. (1995) Politics, Sociology and Social Theory. Stanford: Stanford University Press.

Giddens, A. (1998) The Third Way: The Renewal of Social Democracy. Cambridge: Polity Press.

Glennerster, H. (1988) 'A Requiem for the Social Administration Association', Journal of Social Policy, (17(1): 83-84.

Goldstein, J. (1984) 'Foucault Among the Sociologists: The "Disciplines" and the History of the Professions', History and Theory, 23: 170-192. 
Goldstein, J. (1987) Console and Classify: The French Psychiatric Profession in the Nineteenth Century. Cambridge: Cambridge University Press.

Goldstein, J. (1990) 'The Lively sensibility of the Frenchman': some reflections on the place of France in Foucault's Histoire de la folie', History of the Human Sciences, 3(3): 333-341.

Goldstein, J. (1994) Foucault and the Writing of History. (ed.) Oxford: Basil Blackwell Ltd.

Goldstein, J. (1998) 'Foucault's Technologies of the Self and the Cultural History of Identity', Arcadia, Zeitschrift für Allegmeine und Vergleichende Literaturwissenschaft, 33(1): 46-63.

Goodin, R. E. (1985) 'Vulnerabilities and Responsibilities: An Ethical Defense of the Welfare State', The American Political Science Review, 79(3): 775-787.

Goodin, R. E. (1988) Reasons For Welfare: The Political Theory of the Welfare State. Princeton: Princeton University Press.

Gordon, C. (1980) (ed.) Power/Knowledge: Selected Interviews and Other Writings 19721977. Brighton: The Harvester Press.

Gordon, C. (1986) 'Question, ethos, event: Foucault on Kant and Enlightenment' Economy and Society, 15(1): 71-87.

Gordon, C. (1987) 'The Soul of the Citizen: Max Weber and Michel Foucault on Rationality and Government', in Lash, S. and Whimster, S. (eds.) Max Weber, Rationality and Modernity. London: Allen and Unwin. Pp. 293-316.

Gordon, C. (1990a) 'Histoire de la folie: an unknown book by Michel Foucault', History of the Human Sciences, 3(1): 3-26.

Gordon, C. (1990b) 'History, madness and other errors: a response', History of the Human Sciences, 3(3): 380-396.

Gordon, C. (1991) 'Governmental rationality: an Introduction', in Burchell, G. Gordon, C and Miller, P. (eds.) The Foucault Effect: Studies in Governmentality. Hemel Hempstead:

Harvester Wheatsheaf. Pp. 1-51.

Gordon, C. (1996) 'Foucault in Britain', in Barry, A. Osborne, T. and Rose, N. (eds.) Foucault and Political Reason: Liberalism, Neo-Liberalism and Rationalities of Government. Chicago: The University of Chicago Press. Pp. 253-269.

Gutting, G. (1990) 'Foucault's Genealogical Method', Midwest Studies in Philosophy, XV: $327-$ 343.

Gutting, G. (1994) (ed.) The Cambridge Companion to Foucault. Cambridge: Cambridge University Press.

Habermas, J. (1984) 'Taking Aim at the Heart of the Present', University Publishing, 13: 5-6.

Habermas, J. (1986a) 'The new obscurity: the crisis of the welfare state and the exhaustion of utopian energies', Philosophy \& Social Criticism, 11: 1-18.

Habermas, J. (1986b) 'The Genealogical Writing of History: On Some Aporias in Foucault's Theory of Power', Canadian Journal of Political and Social Theory, X (1-2): 1-9.

Habermas, J. (1987) [translated by Thomas McCarthy] The Theory Of Communicative Action Volume Two: Lifeworld and System: A Critique of Functionalist Reason. Boston: Beacon Press. 
Habermas, J. (1992) The Philosophical Discourse of Modernity: Twelve Lectures. Cambridge, Mass: The MIT Press.

Habermas, J. (1994) 'The Tasks of a Critical Theory', The Polity Reader in Social Theory. Cambridge: Polity Press. Pp. 142-149.

Hacking, I. (1972) 'The Archaeology of Knowledge', Cambridge Review, 93: 166-170.

Hacking, I. (1979) 'Michel Foucault's Immature Science', Noûs, xiii (1): 39-51.

Hacking, I. (1981) 'The Archaeology of Foucault', The New York Review of Books, May $14^{\text {th }}$ : 32-37.

Hacking, I. (1982a) 'Biopower and the Avalanche of Printed Numbers', Humanities in Society, 5: 279-285.

Hacking, I. (1982b) 'Why Are You Scared?', The New York Review of Books, 29(14): 30-33 and 41 .

Hacking, I. (1982c) 'Language, Truth and Reason', in Hollis, M. and Lukes, S. (eds.)

Rationality and Relativism. Oxford: Basil Blackwell. Pp. 48-66.

Hacking, I. (1984) 'Five parables', in Rorty, R. Schneewind, J. B. and Skinner, Q. (eds.) Philosophy in History: Essays on the historiography of philosophy. Cambridge: Cambridge University Press. Pp. 103-124.

Hacking, I. (1986a) 'The Archaeology of Foucault', in Hoy, D. C. (ed.) Foucault: A Critical Reader. Oxford: Blackwell Publishers. Pp. 27-40.

Hacking, I. (1986b) 'Self-Improvement', in Hoy, D. C. (ed.) Foucault: A Critical Reader. Oxford: Blackwell Publishers. Pp. 235-240.

Hacking, I. (1986c) 'Making Up People', in Heller, T. C. Sosna, M. and Wellbery, D. E. (eds.) Reconstructing Individualism: Autonomy, Individuality, and the Self in Western Thought. Stanford: Stanford University Press. Pp. 222-236.

Hacking, I. (1989) 'Two Kinds of "New Historicism" for Philosophers', New Literary History, 21(2): 343-376.

Hacking, I. (1990) The Taming of Chance. Cambridge: Cambridge University Press.

Hacking, I. (1994) 'Memoro-politics, trauma and the soul', History of the Human Sciences, $7(2): 29-52$.

Hacking, I. (1998a) 'On Being More Literal about Construction', in Velody, I. and Williams, R. (eds.) The Politics of Constructionism. London: Sage Publications. Pp. 49-68.

Hacking, I (1998b) Mad Travellers: Reflections on the Reality of Transient Mental IIIness. Charlottesville: University Press of Virginia.

Hacking, I (1999) The Social Construction of What? Cambridge, Mass: Harvard University Press.

Hajer, M. A. (1996) 'Ecological Modernisation as Cultural Politics', in Lash, S. Szerszynski, B. and Wynne, B. (eds.) Risk, Environment And Modernity. London: Sage Publications. Pp. 246-268.

Halperin, D. M. (1995) Saint Foucault: towards a gay hagiography. New York: Oxford University Press. 
Halperin, D. M. (1998) 'Forgetting Foucault: Acts, Identities and the History of Sexuality', Representations, 63: 93-120.

Harpham, G. (1988) 'Foucault and the "Ethics" of power', in Merrill, R. (ed.) Ethics/Aesthetics: Post-Modern Positions. Washington, DC: Maisonneuve Press. Pp. 71-81.

Harpham, G. G. (1994) 'So ... What Is Enlightenment? An Inquisition into Modernity', Critical Inquiry, 20: 524-556.

Hartsock, N. C. M. (1996) 'Postmodernism and Political Change: Issues for Feminist Theory', in Hekman, S. J. (ed.) Feminist Interpretations of Michel Foucault. Pennsylvania: The Pennsylvania State University Press. Pp. 39-55.

Heclo, H. (1994) 'Poverty Politics', in Danziger, S.H. Sandefur, G. D. and Weinberg, D. H. (eds.) Confronting Poverty: Prescriptions for Change. Cambridge, Massachusetts: Harvard University Press. Pp. 396-437.

Hekman, S. J. (1996) (ed.) Feminist Interpretations of Michel Foucault. Pennsylvania: The Pennsylvania State University Press.

Helliwell, C. and Hindess, B. (1999) 'Culture', 'society' and the figure of man', History of the Human Sciences, 12(4): 1-20.

Hermer, J. and Hunt, A. (1996) 'Official Graffiti of the Everyday', Law \& Society Review, 30(3): 455-480.

Hewitt, M. (1983) 'Bio-politics and Social Policy: Foucault's Account of Welfare', Theory Culture \& Society, 2(1): 67-84.

Hewitt, M. (1992) Welfare, Ideology and Need: recent perspectives on the welfare state. Hemel Hempstead: Harvester Wheatsheaf.

Hewitt, M. (1994) 'Social policy and the question of postmodernism', Social Policy Review, 6: 36-57.

Hewitt, M. (1996) 'Social Movements and Social Need: Problems with Postmodern Political Theory', in Taylor, D. (ed.) Critical Social Policy: A Reader. London: Sage Publications. Pp. 199-219.

Hiley, D. R. (1988) Philosophy In Question: Essays on a Pyrrhonian Theme. Chicago: The University of Chicago Press.

Hillyard, P. and Watson, P. (1996) 'Postmodern Social Policy', Journal of Social Policy, 25(3): 321-346.

Hindess, B. (1996a) 'Liberalism, socialism and democracy', in Barry, A. Osborne, T. and Rose, N. (eds.) Foucault and Political Reason: Liberalism, Neo-Liberalism and Rationalities of Government. Chicago: The University of Chicago Press. Pp. 65-80.

Hindess, B. (1996b) Discourses of Power: from Hobbes to Foucault. Oxford: Blackwell Publishers.

Hindess, B. (1997a) 'Politics and governmentality', Economy and Society, 26(2): 257-272.

Hindess, B. (1997b) 'A Society Governed by Contract?', in Davis, G. Sullivan, B. and Yeatman, A. (eds.) The New Contractualism? Melbourne: Macmillan Education. Pp. 14-26.

Hindess, B. (1998a) 'Politics and Liberation', in Moss, J. (ed.) The Later Foucault. London: Sage Publications. Pp. 50-63. 
Hindess, B. (1998b) 'Neo-Liberalism and the National Economy', in Dean, M. and Hindess, B. (eds.) Governing Australia: Studies in Contemporary Rationalities of Government. Cambridge: Cambridge University Press. Pp. 210-226.

Hinkle, G. J. (1986) 'Foucault's power/knowledge and American sociological theorizing', Human Studies, 10: 35-59.

Hirst, P. and Thompson, G. (1995) 'Globalization and the future of the nation state', Economy and Society, 24(3): 408-442.

Hollier, D. (1985) 'Foucault: The Death of the Author', Raritan, 5(1): 22-30.

Holub, R. (1985) 'Trends in Literacy Criticism: Remembering Foucault', The German Quarterly, 58(2): 238-258.

Honneth, A. (1992) 'Integrity And Disrespect: Principles of a Conception of Morality Based on the Theory of Recognition', Political Theory, 20(2): 187-201.

Honneth, A. (1995a) The Fragmented World of the Social: Essays in Social and Political Philosophy. Albany: State University of New York.

Honneth, A. (1995b) The Struggle for Recognition: The Moral Grammar of Social Conflicts. Cambridge: Polity Press.

Honneth, A. (1997) 'Recognition and Moral Obligation', Social Research, 64(1): 16-35.

Honneth, A. and Joas, H. (1988) Social Action and Human Nature. Cambridge: Cambridge University Press.

Hooke, A. (1987) 'The Order of Others: Is Foucault's Antihumanism Against Human Action?', Political Theory, 15(1): 38-60.

Hoy, D. (1981) 'Power, Repression, Progress: Foucault, Lukes, and the Frankfurt School', Triquartery, 52: 43-63.

Hoy, D. C. (1991) 'Foucault: Modern or Postmodern?', in Arac, J. (ed.) After Foucault: Humanistic Knowledge, Postmodern Challenges. New Brunswick: Rutgers University Press. Pp. 12-41.

Huijer, M. (1999) 'The Aesthetics of Existence in the Work of Michel Foucault', Philosophy and Social Criticism, 25(2): 61-85.

Jayasuriya, L. (1996) 'Citizenship and Welfare: Rediscovering Marshall', Australian Journal of Social Issues, 31(1): 19-38.

Johnson, J. (1994) 'Public Sphere, Postmodernism and Polemic', American Political Science Review, 88(2): 427-430.

Johnson, J. (1997) 'Communication, Criticism and the Postmodern Consensus: An Unfashionable Interpretation of Michel Foucault', Political Theory, 25(4): 559-583.

Katznelson, I. (1986) 'Rethinking the Silences of Social and Economic Policy', Political Science Quarterly, 101(2): 307-325.

Keenan, T. (1987) 'The "Paradox" of Knowledge and Power: Reading Foucault on a Bias', Political Theory, 15(1): 5-37.

Kelly, M. (ed.) Critique and Power: Recasting the Foucault/Habermas Debate. Cambridge, Mass: The MIT Press. 
Kemal, S. (1999) 'Aesthetic Licence: Foucault's Modernism and Kant's Post-modernism', International Journal of Philosophical Studies, 7(2): 281-303.

Kemp, P. (1984) 'Review of Dreyfus, H. L. and Rabinow, P. Michel Foucault: Beyond Structuralism and Hermeneutics, History and Theory, 23: 84-105.

Kingdom, J. (1992) No Such Thing as Society. Buckingham: Open University Press.

Kolodny, N. (1996) 'The Ethics of Cryptonormativism: A Defense of Foucault's Evasions', Philosophy and Social Criticism, 22(5): 63-84.

Korsten, F-W. (1998) 'Foucault's Rhetorical Consciousness and the Possibilities of Acting upon a Regime of Truth', Arcadia, Zeitschrift für Allegmeine und Vergleichende

Literaturwissenschaft, 33(1): 64-71.

Lacombe, D. (1996) 'Reforming Foucault: a critique of the social control thesis', British Journal of Sociology, 47(2): 332-352.

Laing, A. (1994) R. D. Laing: A Biography. London: Peter Owen.

Lamb, A. (1995) 'Freedom, the Self, and Ethical Practice According to Michel Foucault', International Philosophical Quarterly, 35(4): 449-467.

Lash, S. (1985) 'Postmodernity and Desire', Theory and Society, 14(1): 1-33.

Lash, S. and Urry, J. (1994) Economies of Signs and Space. London: Sage Publications.

Le Grand, J. (1997) 'Knights, Knaves or Pawns? Human Behaviour and Social Policy', Journal of Social Policy, 26(2): 149-169.

Leland, D. (1975) 'On Reading and Writing the World: Foucault's History of Thought', CLIO, IV(2): 225-43.

Lemert, C. and Gillan, G. (1977) 'The New Alternative in Critical Sociology: Foucault's Discursive Analysis', Cultural Hermeneutics, 4(4): 309-320.

Lemert, C. and Gillan, G. (1982) Michel Foucault: Social Theory and Transgression. New York: Columbia University Press.

Leonard, P. (1994) 'Knowledge/Power and Postmodernism: Implications for the Practice of a Critical Social Work Education', Canadian Social Work Review, 11(1): 11-26.

Leonard, P. (1997) Postmodern Welfare: Reconstructing an Emancipatory Project. London: Sage Publications.

Lloyd, M and Thacker, A. (1997) (eds.) The Impact of Michel Foucault on the Social Sciences and Humanities. Basingstoke, Hampshire: Macmillan Press.

Loney, M. (1987) The Growing Divide: A Social Audit 1979-1987. London: Child Poverty Action Group.

Lowi, T. 'Risks and Rights in the History of American Governments', Daedalus, 119(4): 17-40.

Luhmann, N. (1993) Risk: A Sociological Theory. New York: Aldine De Gruyter.

Lynch, R. A. (1998) 'Is Power All There Is? Michel Foucault and the "Omnipresence" of Power Relations', Philosophy Today, 42(1): 65-73.

Macey, D. (1993) The Lives of Michel Foucault. New York: Simon \& Schuster. 
Macey, D. (1995) 'Michel Foucault” J'Accuse', New Formations, 25: 5-13.

Maher, W and Maher, B. (1982) 'The Ship of Fools: Stultifera Naviz or Ignis Fatuus', American Psychologist, 37(7): 756-761.

Maher, W and Maher, B. (1983) 'The Ship of Fools: A Modern fantasy?', Psychology Today, 17: $68-69$.

Mahon, M. (1993) 'Michel Foucault's Archaeology, Enlightenment and Critique', Human Studies, 16(1-2): 129-141.

Major-Poetzl, P. (1983) Michel Foucault's Archaeology of Western Culture: Towards a New Science of History. Brighton, Sussex: The Harvester Press Ltd.

Major-Poetzl, P. (1990) 'The Disorder of Things', Revue Internationale de Philosophie, 44(2): 198-208.

Malpas, J. and Wickham, G. (1995) 'Governance and failure: on the limits of sociology', Australia and New Zealand Journal of Sociology, 31(3): 37-50.

Margolin, L. (1997) Under the Cover of Kindness: The Invention of Social Work. Charlottesville: University Press of Virginia.

Maslan, M. (1988) 'Foucault and Pragmatism', Raritan, 7(3): 94-114.

May, T. (1993) Between Genealogy and Epistemology: Psychology, Politics, and Knowledge in the Thought of Michel Foucault. Pennsylvania: The Pennsylvania State University

Maxwell, B. (1998) 'Irony in Moral Discourse: Abnegation or Iron fate? Some Considerations on Genealogy, Plurality, and Truth', Dialogue: Canadian Philosophical Review, 37(3): 473491.

McGowen, R. (1994) 'Power and Humanity, or Foucault Among the Historians', in Jones, C. and Porter, R. (eds.) Reassessing Foucault: Power, Medicine and the Body. London: Routledge. Pp. 91-112.

MacIntyre, A. (1988) Whose Society? Which Rationality? London: Duckworth.

McNay, L. (1992) Foucault and Feminism: Power, Gender and the Self. Oxford: Polity Press.

McNay, L. (1998) 'Michel Foucault and Agonistic Democracy', in Carter, A. and Stokes, G. (eds.) Liberal Democracy and its Critics. Cambridge: Polity Press. Pp. 216-237.

McWhorter, L. (1994) 'The Event of Truth: Foucault's Response to Structuralism', Philosophy Today, 38(1): 159-166.

Megill, A. (1979) 'Foucault, Structuralism, and the Ends of History', Journal of Modern History, 51(3): 451-503.

Megill, A. (1985) Prophets of Extremity: Nietzsche, Heidegger, Foucault, Derrida. Berkeley: University of California Press.

Megill, A. (1987) 'The Reception of Foucault by Historians', Journal of the History of Ideas, 48: 117-134.

Megill, A. (1990) 'Foucault, ambiguity, and the rhetoric of historiography', History of the Human Sciences, 3(3): 343-361. 
Megill, A. (1997) 'Surveillance-Free Subjects', in Lloyd, M. and Thacker, A. (eds.) The Impact of Michel Foucault on the Social Sciences and Humanities. London: Macmillan Press Ltd. Pp. 54-77.

Meredyth, D. (1997) 'Invoking citizenship: education, competence and social rights', Economy and Society, 26(2): 271-295.

Merquior, J. G. (1985) Foucault. London: Fontana Press/Collins.

Merquior, J. G. (1990) 'Back to the Histoire de la folie', History of the Human Sciences, 3(1): 39-40.

Midelfort, H. C. E. (1980) 'Madness and Civilization in Early Modern Europe: A Reappraisal of Michel Foucault', in Malament, B. C. (ed.) After the Reformation: essays in honor of J. H. Hexter. Manchester: Manchester University Press. Pp. 247-265.

Midelfort, H. C. E. (1990) 'Comment on Colin Gordon', History of the human Sciences, 3(1): 41-45.

Milchman, A. and Rosenberg, A. (1996) 'Michel Foucault, Auschwitz and Modernity', Philosophy and Social Criticism, 22(1): 101-113.

Miller, J. (1991) 'Michel Foucault: The Heart Laid Bare', Grand Street, 39: 53-65.

Miller, J. (1993a) The Passion of Michel Foucault. New York: Simon \& Schuster.

Miller, J. (1993b) 'Foucault's Politics in Biographical perspective', A Symposium on James Miller's The Passion of Michel Foucault', Salmagundi, 30-44.

Miller, P. (1987) Domination and Power. London: Routledge \& Kegan Paul.

Miller, P. and Rose, N. (1990) 'Governing Economic Life', Economy and Society, 19(1): 1-31.

Mills, P. J. (1994) ‘Feminist Critical Theory’, Science \& Society, 58(2): 211-217.

Mink, G. (1994) 'Welfare Reform in Historical Perspective', Social Justice, 21(1): 114-131.

Minson, J. (1980) 'Strategies for socialists? Foucault's conception of power', Economy and Society, $9(1): 1-43$.

Minson, J. (1985) Genealogies of Morals: Nietzsche, Foucault, Donzelot and the Eccentricity of Ethics. Basingstoke: Macmillan.

Mishra, R. (1999) Globalization and the Welfare State. London: Edward Elgar.

Morris, M. and Patton, P. (1979) (eds.) Michel Foucault: Power, Truth, Strategy. Sydney: Feral Publications.

Mottier, V. (1995) 'A tool box of deadly spanners', in The Times Higher Education Supplement. \# 1197 October 1995. A review of Dits et Ecrits 1954-1988.

Mouffe, C. (1992) (ed.) Dimensions of Radical Democracy: Pluralism, Citizenship, Community. London: Verso.

Mouffe, C. (1995) 'Feminism, citizenship, and radical democratic politics', in Nicholson, L. and Seidman, S. (eds.) Social postmodernism: Beyond identity politics. Cambridge: Cambridge University Press. Pp. 315-331.

Moussa, M. (1991) 'misunderstanding the democratic "we": Richard Rorty's liberalism and the radical urge for a philosophical foundation', Philosophy and Social Criticism, 17(4): 297-312. 
Moussa, M. and Scapp, R. (1996) 'The Practical Theorizing of Michel Foucault: Politics and Counter-Discourse', Cultural Critique, 33: 87-112.

Murphy, J. (1984) 'Foucault's Ground of History', International Philosophical Quarterly, XXIV(2): 189-196.

Nehamas, A. (1986) 'What an Author Is', The Journal of Philosophy, LXXX111(11): 685-691.

Nehamas, A. (1987) 'Writer, Text, Work, Author', in Cascandi, A. J. (ed.) Literature and The Question of Philosophy. Baltimore: John Hopkins University Press. Pp. 267-291.

Nehamas, A. (1993) 'The examined life of Michel Foucault: Subject and Abject', The New Republic, 208(6): 27-36.

Nehamas, A, (1998) The Art of Living: Socrates' Reflections from Plato to Foucault. Berkeley: University of California Press.

Nielsen, K. (1997) 'Habermas and Foucault: How to carry out the Enlightenment project', The Journal of Value Inquiry, 31(1): 5-21.

Nietzsche, F. (1958) Thus Spake Zarathustra. London: J.M. Dent \& Sons.

Nietzsche, F. (1983) Untimely Meditations. Cambridge: Cambridge University Press.

Nietzsche, F. (1996) On the Genealogy of Morals: A Polemic. (trans. Douglas Smith). Oxford: Oxford University Press.

Nietzsche, F. (1997) Daybreak: Thoughts on the Prejudices of Morality. (Clark, M. and Lester, B. eds.) Cambridge: Cambridge University Press.

Noiriel, G. (1994) 'Foucault and History: The Lessons of a Disillusion', Journal of Modern History, 66(3): 547-568.

O'Brien, P. (1989) 'Foucault's History of Culture', in Hunt, L. (ed.) The New Cultural History. Berkeley: University of California Press. Pp. 25-46.

O'Brien, M and Penna, S. (1998a) Theorising Welfare: Enlightenment and Modern Society. London: Sage Publications.

O'Brien, M and Penna, S. (1998b) 'Oppositional postmodern theory and welfare analysis: anti-oppressive practice in a postmodern frame', in Carter, J. (ed.) Postmodernity and the Fragmentation of Welfare. London and New York; Routledge. Pp. 49-66.

Offe, C. (1981) 'Some Contradictions in the Modern Welfare State', Praxis International, 1(3): 219-229.

Offe, C. (1996) Modernity and the State. Cambridge, Mass: The MIT Press.

O'Connor, T. (1988) 'Foucault and the Transgression of Limits', in Silverman, H.J. (ed.) Philosophy and Man - Philosophy Since Merleau-Ponty. London: Routledge. Pp 136-151.

O'Hara, D. T. (1991a) 'What Was Foucault', in Arac, J. (ed.) After Foucault: Humanistic Knowledge, Postmodern Challenges. New Brunswick: Rutgers University Press. Pp. 71-96.

O'Hara, D. T. (1991b) 'Michel Foucault and the Fate of Friendship', boundary 2, 18(1) 81-103.

O'Hara, D. T. (1992) Radical Parody: American Culture and Critical Agency After Foucault. New York: Columbia University Press. 
O'Malley, P. (1991) 'Legal Networks and Domestic Security', Studies in Law, Politics and Society, 11: 171-190.

O'Malley, P. (1993) 'Containing Our Excitement: Commodity Culture and the Crisis of Discipline', Studies in Law, Politics, and Society, 13: 159-186.

O'Malley, P. (1996) 'Risk and Responsibility', in Barry, A. Osborne, T. and Rose, N. (eds.) Foucault and Political Reason: Liberalism, Neo-Liberalism and Rationalities of Government. Chicago: The University of Chicago Press. Pp. 189-207.

O'Malley, P. (1999) 'Governmentality and the risk society', Economy and Society, 28(1): 138148.

O'Malley, P. Weir, L. and Shearing, C. (1997) 'Governmentality, criticism, politics', Economy and Society, 26(4): 501-517.

Osborne, T. (1994) 'Sociology, liberalism and the historicity of conduct', Economy and Society, 23(4): 484-501.

Osborne, T. (1998a) 'Constructionism, Authority and the Ethical Life', in Velody, I. and Williams, R. (eds.) The Politics of Constructionism. London: Sage Publications. Pp. 221-234.

Osborne, T. (1998b) Aspects of Enlightenment: Social Theory and the Ethics of Truth. Lanham, Maryland: Rowan and Littlefield.

Owen, D. 1994) Maturity and Modernity: Nietzsche, Weber, Foucault and the Ambivalence of Reason. London: Routledge.

Owen, D. (1995) 'Genealogy as exemplary critique: reflections on Foucault and the imagination of the political', Economy and Society, 24(4): 489-506.

Owen, D. (1996) 'Foucault, Habermas and the claims of reason', History of the Human Sciences, 9(2): 119-138.

Paden, R. (1987) 'Foucault's Anti-Humanism', Human Studies, 10(1): 123-141.

Parsons, S. (1988) 'Foucault and the Problem of Kant', Praxis International, 8(3): 317-328

Parton, N. (1996) 'Social work, risk and the 'blaming system", in Parton, N. (ed.) Social Theory, Social Change and Social Work. London: Routledge. Pp. 98-114.

Pasquino, P. (1986) 'Michel Foucault (1926-84): The will to knowledge', Economy and Society, 15(1): 97-109.

Pasquino, P. (1993) 'Political theory of war and peace: Foucault and the history of modern political theory', Economy and Society, 22(1): 77-88.

Patton, P. (1984/5) 'Michel Foucault: The Ethics of an Intellectual', Thesis Eleven, 10-11: 7180.

Patton, P. (1989) 'Taylor and Foucault on Power and Freedom', Political Studies, 37(2): 260276.

Patton, P. (1994) 'Foucault's Subject of Power', Political Theory Newsletter, 6(1): 60-71.

Pavlich, G. (1995) 'Contemplating a postmodern sociology: genealogy, limits and critique', The Sociological Review, 43(3): 548-572.

Pearce, F. and Tombs, S. (1998) 'Foucault, Governmentality, Marxism', Social \& Legal Studies, 7(4): 567-575. 
Pels, D. (1995) 'The Politics of Critical Description: Recovering the normative complexity of Foucault's pouvoir/savoir', American Behavioral Scientist, 38(7): 1018-1041.

Penna, S. and O'Brien, M. (1996) 'Postmodernism and Social Policy: A Small Step Forwards?', Journal of Social Policy, 25(1): 39-61.

Philp, M. (1983) 'Foucault on Power: A Problem in Radical Translation', Political Theory, 11(1): 29-52.

Philp, M. (1985) 'Michel Foucault', in Skinner, Q. (ed.) The Return of Grand Theory in the Human Sciences. Cambridge: Cambridge University Press. Pp. 65-77.

Pickett, B. (1996) 'Foucault and the Politics of Resistance', Polity, XXVIII(4): 445-66.

Pierson, C. (1991) Beyond the Welfare State? Cambridge: Polity Press.

Pleasants, N. (1997) 'The Epistemological Argument against Socialism: A Wittgensteinian Critique of Hayek and Giddens', Inquiry: An Interdisciplinary Journal of Philosophy, 40(1): 2346.

Poster, M. (1980) 'Foucault's True Discourses', Humanities in Society, 2: 153-166.

Poster, M. (1982) 'Foucault and History', Social Research, 49(1): 116-142.

Poster, M. (1989) Cultural Theory and Poststructuralism: In Search of a Context. Ithaca: Cornell University Press.

Poster, M. (1997) Cultural History and Postmodernity: Disciplinary Readings and Challenges. New York: Columbia University Press.

Powell, M. and Hewitt, M. (1998) 'The End of the Welfare State?', Social Policy and Administration, 32(1): 1-13.

Pratt, J. (1985) 'Review Article: The Legacy of Foucault', International Journal of the Sociology of Law, 13: 289-293.

Pratt, J. (1996) 'Reflections On Recent Trends Towards The Punishment of Persistence', Crime Law \& Social Change, 25(3): 243-264.

Pratt, J. (1997) Governing the Dangerous: dangerousness law and social change. Sydney: The Federation Press.

Procacci, G. (1989) 'Sociology and Its Poor', Politics \& Society, 17: 163-187.

Procacci, G. (1991) 'Social economy and the government of poverty', in Burchell, G. Gordon, C and Miller, P. (eds.) The Foucault Effect: Studies in Governmentality. Hemel Hempstead: Harvester Wheatsheaf. Pp. 151-168.

Procacci, G. (1994) 'Governing Poverty: Sources of the Social Question in NineteenthCentury France', in Goldstein, J. (ed.) Foucault and the Writing of History. Oxford: Basil Blackwell Ltd. Pp. 206-219.

Rabinow, P. (1996) Essays on the Anthropology of Reason. Princeton: Princeton University Press.

Racevskis, K. (1980) 'The Discourse of Michel Foucault: A Case of an Absent and Forgettable Subject', Humanities in Society, 3: 44-54. 
Rajan, T. (1998) 'The Phenomenological Allegory: From Death and the Labyrinth to The Order of Things', Poetics Today: International Journal for Theory and Analysis of Literature and Communication, 19(3): 439-466.

Rajchman, J. (1977) 'Analysis in Power: A few Foucauldian Theses', Semiotext(e), 2(3): 4558.

Rajchman, J. (1983a) 'Foucault, or the Ends of Modernism', October, 24: 37-62.

Rajchman, J. (1983b) 'The Story of Foucault's History', Social Text, 8: 3-24.

Rajchman, J. (1985) Michel Foucault: The Freedom of Philosophy. New York: Columbia University Press.

Rajchman, J. (1986) 'Ethics after Foucault', Social Text, 13/14: 165-183.

Rajchman, J. (1989) 'Crisis', Representations, 28: 90-98.

Rajchman, J. (1991) Truth and Eros: Foucault, Lacan and the Question of Ethics. New York: Routledge.

Ransom, J. (1997) 'Forget Vitalism: Foucault and Lebensphilophie', Philosophy and Social Criticism, 23(1): 33-47.

Raulet, G. (1983) ' Structuralism and Post-Structuralism: An Interview with Michel Foucault', Telos, 55: 195-211.

Rawson, C. (1994) 'The Masks of M. Foucault', The Sewanee Review, 102(3): 471-476.

Ray, L. (1988) 'Foucault, Critical Theory and the Decomposition of the Historical Subject', Philosophy and Social Criticism, 14(1): 69-107.

Reid, R. (1997) 'Foucault in America: Biography, "Culture War", and the New Consensus', Cultural Critique, 35: 179-211.

Richardson, T. (1996) 'Foucauldian Discourse: Power and Truth in Urban and Regional Policy Making', European Planning Studies, 4(3): 279-292.

Richters, A. (1988) 'Modernity-Postmodernity Controversies: Habermas and Foucault', Theory, Culture \& Society, 5: 611-643.

Rorty, R. (1982) Consequences of Pragmatism: Essays 1972-1980. Brighton: Harvester.

Rorty, R. (1990) 'Foucault/Dewey/Nietzsche', Raritan, 10(4): 1-8.

Rorty, R. (1991) Essays on Heidegger And Others: Philosophical Papers Volume 2. Cambridge: Cambridge University Press.

Rorty, R. (1995) 'Habermas, Derrida, And The Functions of Philosophy', Revue Internationale De Philosophie, 49(194): 437-459.

Rose, N. (1996a) 'The death of the social? Re-figuring the territory of government', Economy and Society, 25(3): 327-356.

Rose, N. (1996b) 'Governing "advanced” liberal democracies', in Barry, A. Osborne, T. and Rose, N. (eds.) Foucault and Political Reason: Liberalism, Neo-Liberalism and Rationalities of Government. Chicago: The University of Chicago Press. Pp. 37-64.

Rose, N. (1996c) 'Psychiatry as a political science: advanced liberalism and the administration of risk', History of the Human Sciences, 9(2): 1-23. 
Rose, N. (1999) Powers of Freedom: Reframing Political Thought. Cambridge: Cambridge University Press.

Rose, N. (2000) 'Vital politics and the government of life itself' (Unpublished paper - Ethos of Welfare Conference, Helsinki, August 2000).

Rose, N. and Miller, P. (1992) 'Political power beyond the state: Problematics of government', British Journal of Sociology, 43(2): 173-205.

Ross, S. (1986) 'Foucault's Radical Politics', Praxis International, 5(4): 131-144.

Roth, M. S. (1981) 'Foucault's "History of the Present"', History and Theory: Studies in the Philosophy of History, XX: 32-46.

Roth, M. S. (1991) 'The Ironist's Cage', Political Theory, 19(3): 419-432.

Rousseau, G. (1972-3) 'Whose Enlightenment? Not Man's: The Case of Michel Foucault', Eighteenth Century Studies, 6(2): 238-256.

Rybalka, M. (1985) 'Michel Foucault, Philosopher of Exclusion', Contemporary French Civilization, 9(2): 192-198.

Said, E. (1972) 'Michel Foucault as an Intellectual Imagination', Boundary 2, 1(1) 1-36.

Said, E. (1974) 'An Ethics of Language', Diacritics, 4(2): 28-37.

Said, E. W. (1991) 'Michel Foucault, 1926-1984', in Arac, J. (ed.) After Foucault: Humanistic Knowledge, Postmodern Challenges. New Brunswick: Rutgers University Press. Pp. 1-11.

Saunders, P. (1993) 'Citizenship in a Liberal Society', in Turner, B. S. (ed.) Citizenship and Social Theory. London: Sage Publications. Pp. 57-90.

Sawicki, J. (1988) 'Identity Politics and Sexual Freedom: Foucault and Feminism', in Diamond, I. and Quinby, L. (eds.) Feminism and Foucault: Reflections on Resistance. Boston: Northeastern University Press. Pp. 177-191.

Sawicki, J. (1991) 'Feminism And The Power Of Foucauldian Discourse', in Arac, J. (ed.) After Foucault: Humanistic Knowledge, Postmodern Challenges. New Brunswick: Rutgers University Press. Pp. 161-178.

Scott, J. W. (1996) 'After History', Common Knowledge, Pp. 9-26.

Scull, A. (1990) 'Michel Foucault's history of madness', History of the Human Sciences, 3(1): 57-67.

Schneck, S. (1997) 'The Human Sciences and the End of History: Hegel, Nietzsche, Weber and Foucault', International Studies in Philosophy, 29(4): 59-79.

Seigel, J. (1990) 'Avoiding the Subject: A Foucaultian Itinerary', Journal of the History of Ideas, 273-299.

Sennett, R. (1981) 'Sexuality and Solitude: Michel Foucault and Richard Sennett', London Review of Books, $21^{\text {st }}$ May- $3^{\text {rd }}$ June: 3-7.

Shaw, P. (1999) 'Whatever Happened to the French Foucault? Norris on Foucault', Journal for the British Society for Phenomenology, 30(3): 275-290.

Shiner, L. (1982) 'Reading Foucault: Anti-Method and the Genealogy of Power-Knowledge', History and Theory, 21(3): 382-398. 
Shipley, J. (1991) Social Assistance: Welfare That Works. A Statement of Government Policy on Social Assistance. Wellington: Government Print.

Shklar, J. (1987) 'Review of The Needs of Strangers' by Michael Ignatieff', Political Theory, 15(1): $141-145$.

Shklar, J. (1989) 'The Liberalism of Fear', in Rosenblum, N. L. (ed.) Liberalism and the Moral Life. Cambridge, Mass: Harvard University Press. Pp. 21-38.

Silverman, D. (1993) Interpreting Qualitative Data: Methods for Analysing Talk, Text and Interaction. London: Sage Publications.

Smart, B. (1983) 'On Discipline and Social Regulation: a Review of Foucault's Genealogical Analysis', in Garland, D. and Young, P. (eds.) The Power to Punish: Contemporary Penality and Social Analysis. London: Heinemann Educational Books Ltd. Pp. 62-83.

Smart, B. (1985) Michel Foucault. London: Tavistock.

Smart, B. (1986) 'The Politics of Truth and the Problem of Hegemony', in Hoy, D. C. (ed.) Foucault : A Critical Reader. Oxford: Blackwell. Pp. 157-173.

Smart, B. (1990) 'On the Disorder of Things: Sociology, Postmodernity and the 'End of the Social', Sociology, 24(3): 397-416.

Smart, B. (1991) 'On the Subjects of Sexuality, Ethics and Politics in the Work of Foucault', boundary $2,18(1): 201-225$.

Squires, P. (1990) Anti-Social Policy: Welfare, Ideology and the Disciplinary State. New York: Harvester Wheatsheaf.

Squires, P. (1992) Review of Dean, M. (1991) The Constitution of Poverty: Towards a Genealogy of Liberal Governance, The International Journal of Sociology and Social Policy, 12(1-2): 98-100.

Steiner, G. (1986) 'Power Play', New Yorker, March $17^{\text {th }}, 62: 1-6$.

Stenson, K. (1998) 'Beyond Histories of the Present', Economy and Society, 27(4): 333-352.

Stenson, K. (1999) 'Crime Control, Governmentality and Sovereignty', in Smandych, R. (ed.) Governable Places: Readings in Governmentality and Crime Control. Aldershot: Dartmouth. Pp. 1-24.

Stenson, K. and Watt, P. (1999) 'Governmentality and the 'Death of the Social'?: A Discourse Analysis of Local Government texts in South-East England', Urban Studies, 36(1): 189-201.

Szakolczai, A. (1998a) "Il faut defendre le societe". Cours au College de France (book reviews) The American Journal of Sociology, 103(5): 1402-1409.

Szakolczai, A. (1998b) 'Reappraising Foucault', American Journal of Sociology, 103(5): 14021410.

Taylor, C. (1985) 'Connolly, Foucault, and Truth', Political Theory, 13(3): 377-385.

Taylor, C. (1986) 'Foucault on Freedom and Truth', in Hoy, D. C. (ed.) Foucault A Critical Reader. Oxford: Blackwell. Pp. 69-102.

Taylor, C. (1989) 'Taylor and Foucault on Power and freedom: a Reply', Political Studies, xxxvii: 277-281. 
Taylor, C. (1992) Multiculturalism and "the Politics of Recognition". Princeton: University Press.

Taylor, C. (1995) Philosophical Arguments. Cambridge, Mass: Harvard University Press.

Taylor- Gooby, P. (1987) 'Welfare Attitudes: Cleavage, Consensus and Citizenship', The Quarterly Journal Of Social Affairs, 3(3): 199-211.

Taylor-Gooby, P. (1993) 'Citizenship, Dependency, and the Welfare Mix: Problems of Inclusion and Exclusion', International Journal of Health Services, 23(3): 455-474.

Taylor-Gooby, P. (1997) 'European Welfare Futures: The Views of Key Influentials in Six European Countries on Likely Developments in Social Policy', Social Policy and Administration, 31(1): 1-19.

Thatcher, M. (1993) The Downing Street Years. London: Harper-Collins.

Thiele, L. (1990) 'The Agony of Politics: The Nietzschean Roots of Foucault's Thought', American Political Science Review, 84(3): 907-925.

Thiele, L. (1991) 'Reading Nietzsche and Foucault: A Hermeneutics of Suspicion', American Political Science Review, 85(2): 581-591.

Titmuss, R. M. (1970) The Gift Relationship. London: George Allen \& Unwin Ltd.

Titmuss, R. M. (1974) Social Policy: An Introduction. London: Allen \& Unwin Ltd.

Touey, D. (1998) 'Foucault's Apology', Journal for the Theory of Social Behaviour, 28(1): 83106.

Tully, J. (1999a) 'The agonic freedom of citizens', Economy and Society, 28(2): 161-182.

Tully, J. (1999b) 'To Think and Act Differently: Foucault's Four Reciprocal Objections to Habermas' Theory', in Ashenden, S. and Owen, D. (eds.) Foucault Contra Habermas: Recasting the Dialogue between Genealogy and Critical Theory. London: Sage Publications. Pp. 90-142.

Turner, B. S. (1985) 'The Practices of Rationality: Michel Foucault, Medical History and Sociological Theory', in Fardon, R. (ed.) Power and Knowledge: Anthropological and Sociological Approaches. Edinburgh: Scottish Academic Press. Pp. 193-213.

Turner, B. S. (1993) 'Outline of a Theory of Human Rights', Sociology, 27(3): 489-512.

Turner, B. S. (1994) Orientalism, postmodernism and globalism. London and New York: Routledge.

Turner, B. S. (1995) Medical Power and Social Knowledge. (Second Edition). London: Sage Publications.

Turner, B. S. (1997) 'From governmentality to risk, some reflections on Foucault's contribution to medical sociology', Foreword to Petersen, A. R. and Bunton, R. (eds.) Foucault, Health and Medicine. London: Routledge. Pp. ix-xvi.

Valero-Silva, N. (1996) 'Towards a Critique of Critical Systems Thinking Within a Foucauldian Framework: A "Demystification Process" or an "Instrumental Use" of Critical Theory', Systems Practice, 9(5): 539-546.

Valverde, M. (1996) 'Despotism' and ethical liberal governance', Economy and Society, 25(3): 357-372. 
Valverde, M. (1999) 'The Personal is the Political: justice and gender in deconstruction', Economy and Society, 28(2): 300-311.

van Krieken, R. (1996) 'Proto-governmentalization and the historical formation of organizational subjectivity', Economy and Society, 25(2): 195-211.

Venn, C (1997) 'Beyond enlightenment? After the subject of Foucault, who comes?', Theory Culture and Society, 14(3): Pp.1-28

Veyne, P. (1971) Writing History: Essay on Epistemology. Middletont: Wesleyan University Press.

Veyne, P. (1982) 'The inventory of differences', Economy and Society, 11(2): 173-198.

Veyne, P. (1993) 'The Final Foucault and His Ethics', Critical Inquiry, 20(1): 1-9.

Veyne, P. (1997) 'Foucault Revolutionizes History', in Davidson, A. I. (ed.) Foucault And His Interlocutors. Chicago: The University of Chicago Press. Pp. 146-182.

Visker, R. (1990) 'Can Genealogy be Critical? A somewhat Unromantic Look at Nietzsche and Foucault', Man and World, 23(4): 441-452.

Visker, R. (1991) 'From Foucault to Heidegger: A One-way Ticket?', Research in Phenomenology, 21: 116-140.

Walters, W. (1997) 'The 'Active Society': new designs for social policy', Policy and Politics, 25(3): 221-234.

Wartenberg, T. (1984) 'Foucault's Archaeological Method: A Response to Hacking and Rorty', The Philosophical Forum, XV(4): 345-363.

Weberman, D. (1995) 'Foucault's Reconception of Power', Philosophical Forum, 26(3): 189217.

Weightman, J. (1989) 'On not understanding Michel Foucault', The American Scholar, 58 : 383-406.

White, H. (1973) 'Foucault Decoded: Notes From Underground', History and Theory, 12: 2-54.

White, H. (1978) 'Power and the World', Canto, 2(1): 164-172.

White, S. K. (1986) 'Foucault's Challenge to Critical Theory', American Political Science Review, 80(2): 419-432.

White, S. K. (1988a) The Recent Work of Jurgen Habermas: Reason justice and modernity. Cambridge: Cambridge University Press.

White, S. K. (1988b) 'Poststructuralism And Political Reflection', Political Theory, 16(2): 186208.

Woodruffe, K. (1966) From Charity to Social Work: In England and the United States. London: Routledge \& Kegan Paul.

Wynne, B. (1996) 'May the Sheep Safely Graze? A Reflexive View of the Expert-Lay Knowledge Divide', in Lash, S. Szersynski, B. and Wynne, B. (eds.) Risk, Environment and Modernity: Towards a New Ecology. London: Sage Publications. Pp. 44-83.

Young, I. M. (1990) Justice and the Politics of Difference. Princeton, New Jersey: Princeton University Press. 
Young, I. M. (1996) 'Political Theory: An Overview', in Goodin, R. E. and Klingemann, H-D.

(eds.) A New Handbook of Political Science. Oxford: Oxford University Press. Pp. 479-502.

\section{Supplementary Bibliography - Reviews of Foucault's Books}

\section{(i) Madness and Civilization: A History of Insanity in the Age of Reason}

Friedenberg, E. Z. (1965) 'Sick, Sick, Sick', The New York Times Book Review, August $22^{\text {nd }}$ 70: 6 .

Gay, P. (1965) 'Chains and Couches', Commentary, 40: 93-96.

Howard, R. (1965-6) Review of Madness and Civilization, Choice, 2: 735.

Laing, R. D. (1967) 'The Invention of Madness', New Statesman, June $16^{\text {th }} 73: 843$.

Leitch. E. (1967) 'Imprisoned by Madness', The Listener, 77: 752-753.

Matza, D. (1966) Review of Madness and Civilization, American Sociological Review, 31: 551-552.

Peters, M. (1971) Review of Madness and Civilization, Sociological Review, 19: 634-638.

Rieff, P. (1967) Review of Madness and Civilization, American Academy of Political and Social Science, Annals, 371: 258-259

Reider, N. (1965) 'Madness in the Age of Reason', The Nation, 201: 22-23.

Rosen, G. (1967) Review of Madness and Civilization, Journal of the History of Behavioral Sciences, 3: 209-211.

Rousseau, G. S. (1970) Review of Madness and Civilization, Eighteenth-Century Studies, 4(1): 90-95.

Scruton, R. (1971) 'on madness and method', Spectator, October $9^{\text {th }} 227: 513$

Simon, J. 1963) Review of Madness and Civilization, Modern Language Notes, 78: 85-88.

\section{(ii) Birth of the Clinic: An Archaeology of Medical Perception}

Aronson, A. L. (1974) 'Medicine: History and Theory', Yale Review, 63: 473-476.

Caws, P. (1973) 'Medical Change', New Republic, November $10^{\text {th }} 169: 28-30$.

Hahn, R. (1975) Review of Birth of the Clinic, American Journal of Sociology, 80: 1503-4.

Howe, M. (1974) 'Open Up a Few Corpses', The Nation, 218: 117-119.

Kupers, T. A. (1975) Review of Birth of the Clinic, Science and Society, 39: 235-238.

Lasch, C. (1974) 'after the church doctors, after the doctors utopia', The New York Times Book Review, 24: 6.

Sheridan-Smith, A. M. (1974-5) Review of Birth of the Clinic, Choice, 11(1-6): 114.

Starobinski, J. (1976) 'Gazing at Death', The New York Review of Books, January $22^{\text {nd }} 22$ : $18, \& 20-22$. 
Zeldin, T. (1973) 'An Archaeologist of Knowledge', New Statesman, 86: 861-862.

\section{(iii) The Order of Things: An Archaeology of the Human Sciences}

Bossy, J, (1971) 'Abstract Acrobat', New Statesman, 81: 775.

Caws, P. (1979) 'Language as the Human Reality', New Republic, March $27^{\text {th }}, 164: 28-34$.

Harding, D. W. (1973) 'Good-by Man', New York Review of Books, 17: 21-22.

Howard, R. (1971) ' Our sense of where we are', The Nation, 213: 21-2.

Huppert, G. (1974) 'Divinatio et Eruditio: Thoughts on Foucault', History and Theory: Studies in the Philosophy of History, 13(3): 191-207.

Moore, J. H. (1971) Review of The Order of Things, Science and Society, 35: 490-494.

Steiner, G. (1971a) 'The Mandarin of the Hour'. Review of The Order of Things ', The New York Times Book Review, February $28^{\text {th }} 17: 8,28-31$.

Steiner, G. (1971b) 'Steiner responds to Foucault', diacritics, 2: 59.

\section{(iv) The Archaeology of Knowledge and The Discourse on Language}

Caws, P. (1972) 'An immense density of systematicities', New York Times Book Review, October $22^{\text {nd }} 22$ : 6-8.

Kermode, F. (1973) 'Crisis Critic', The New York Review of Books, 20: 37-38.

Leland, D. (1975) 'On Reading and Writing the World: Foucault's History of Thought', Clio iv(2): 225-243.

Said, E. (1974) 'An Ethics of Language', diacritics: a review of contemporary criticism, 4(2): 28-37.

\section{(v) Discipline and Punish: The Birth of the Prison}

Bersani, L. (1977) 'The Subject of Power', diacritics: a review of contemporary criticism, September: 2-21.

Brown, R. (1978) 'The Idea of Imprisonment', Times Literary Supplement, June $16^{\text {th }}$.

Cohen, S. (1978) 'The Archaeology of Power', Contemporary Sociology, 7: 566-568.

Coles, R. (1979) 'From Torture to Technology', New Yorker, January 29 ${ }^{\text {th }}, 54: 95$.

D'Amico, R. (1978) Review of Discipline and Punish, Telos, 36: 169-183.

Di Piero, W. S. (1978) Review of Discipline and Punish, Commonweal, 105: 313-315.

Geertz, C. (1978) 'Stir Crazy' The New York Review of Books, 24: 3-5.

Harding, D. W. (1977) 'Towards Total Control of Man', The Listener, 98: 802.

Hussain, A. (1978) Extended Review of Discipline and Punish, Sociological Review, 26: 932939. 
Jackson, B. (1978) 'The Machineries of Control', The Nation, 226: 250-251.

Kaplan, R. (1978) 'Jail and Society', Commentary, 65: 83-86.

Rothman, D. J. (1978) 'Society and Its Prisons', The New York Times Book Review, 19: 1, and 26-27.

Seem, M. (1976) Review of Discipline and Punish, Telos, 29: 245-254.

Shelley, L.I. (1979) Review of Discipline and Punish, American Journal of Sociology, 84: 1508-1510.

Sheridan, A. (1978-79) Review of Discipline and Punish, Choice, 15(1-6): 471.

Simon, J. (1996) 'Discipline and Punish: The Birth of a middle-Range Research Strategy', Contemporary Sociology, 25(3): 316-319.

White, H. V. (1977) Review of Discipline and Punish, American Historical Review, 82: 605606.

\section{(vi) The History of Sexuality, Volume 1: An Introduction}

Adamowski, T. H. (1979) 'Sex in the Head', Canadian Forum, 59: 40-42.

Adams, M. V. (1979) 'Review of The History of Sexuality', Commentary, 67: 84-87.

Amato, J. (1984) 'Review of The History of Sexuality', The Annals of the American Academy, 454: 239-241.

Conrad, P. (1979) 'Syntax and Sin', Review of The History of Sexuality', New Statesman, 97: 451-2.

Gilbert, A. N. (1979) Review of The History of Sexuality, American Historical Review, 84: 1020.

Gordon, C. (1988) 'Live like a Human', New Statesman, May 6 ${ }^{\text {th }}$ 2980: 22-23.

Ignatieff, M. (1984) 'Anxiety and asceticism', Times Literary Supplement, September $28^{\text {th }}$ p.1071.

Lasch, C. (1980) 'Life in the Therapeutic State', The New York Review of Books, 27: 24-32.

Lloyd, G. E. R. (1986) 'The Mind on Sex', New York Review of Books, March $13^{\text {th }}$ Pp. 24-28.

Poirier, R. (1979) 'The Powerful Secret', The New York Times Book Review, January $14^{\text {th }} 1-3$.

Sennett, R, (1979) Review of The History of Sexuality, New Yorker, July $16^{\text {th }}, 55: 101$.

Turkle, S. (1979) 'Sound Over Sense', Review of The History of Sexuality, The Nation, 228: 92-94.

Vera, H. (1979) Review of The History of Sexuality, Contemporary Sociology, 8: 589-590.

Vine, R. (1979) 'The History of an Illusion', Georgia Review, 33: 918-922.

White, H. V. (1977) 'The Archaeology of Sex', Times Literary Supplement, May $6^{\text {th }}$ p. 565. 


\section{Power/Knowledge: Selected Interviews \& Other Writings 1972-1977}

Adamowski, T, H. (1981) 'The Man who would be King', Canadian Forum, 61: 31-32.

Kennedy, D. (1979) 'The Archaeology and Sociology of Knowledge', Theory and Society, 8(2): 269-290. 